\title{
‡USGS
}

science for a changing world

Prepared in cooperation with the City of Palo Alto, California

Near-Field Receiving Water Monitoring of Trace Metals and a Benthic Community Near the Palo Alto Regional Water Quality Control Plant in South San Francisco Bay, California: 2012

Open-File Report 2013-1144

U.S. Department of the Interior U.S. Geological Survey 
Cover Image:

Sunset at Baylands.

Oil on Canvas, 26x36 inches, by Tonya Zenin.

Copyright Antonina Zenin Fine Art

http://tonyazenin.com/ 


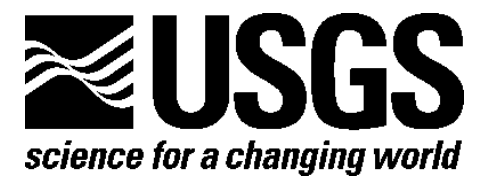

Prepared in cooperation with the City of Palo Alto, California

\section{Near-Field Receiving Water Monitoring of Trace Metals and a Benthic Community Near the Palo Alto Regional Water Quality Control Plant in South San Francisco Bay, California: 2012}

By Jessica L. Dyke, Janet K. Thompson, Daniel J. Cain, Amy E. Kleckner, Francis Parchaso, Samuel N. Luoma, and Michelle I. Hornberger

Open-File Report 2013-1144 


\section{U.S. Department of the Interior SALLY JEWELL, Secretary}

\section{U.S. Geological Survey \\ Suzette M. Kimball, Acting Director}

U.S. Geological Survey, Reston, Virginia: 2013

For product and ordering information:

World Wide Web: http://www.usgs.gov/pubprod

Telephone: 1-888-ASK-USGS

For more information on the USGS-the Federal source for science about the Earth, its natural and living resources, natural hazards, and the environment:

World Wide Web: http://www.usgs.gov

Telephone: 1-888-ASK-USGS

Suggested citation:

Dyke, J.L., Thompson, J.K., Cain, D.J., Kleckner, A.E., Parchaso, F., Luoma, S.N., and Hornberger, M.I., Near-field receiving water monitoring of trace metals and a benthic community near the Palo Alto Regional Water Quality Control Plant in south San Francisco Bay, California, 2012, U.S. Geological Survey Open-File Report 2013-1144, 109 p., http://pubs.usgs.gov/of/2013/1144/.

Any use of trade, product, or firm names is for descriptive purposes only and does not imply endorsement by the U.S. Government.

Although this information product, for the most part, is in the public domain, it also may contain copyrighted materials as noted in the text. Permission to reproduce copyrighted items must be secured from the copyright owner. 


\section{Contents}

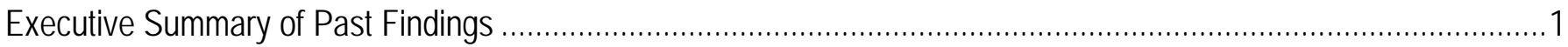

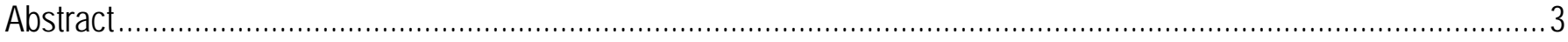

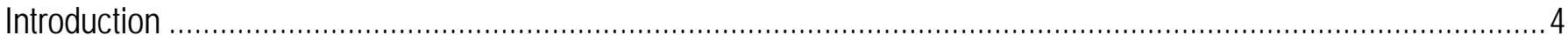

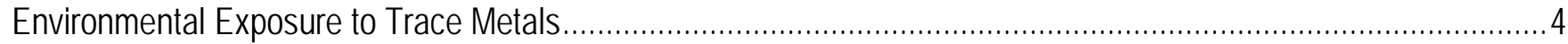

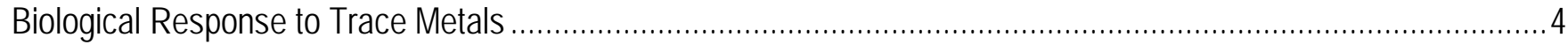

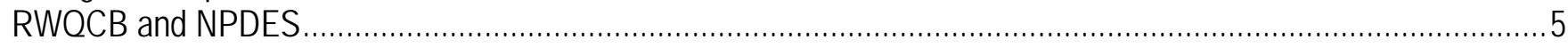

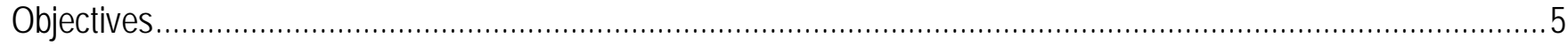

Approach

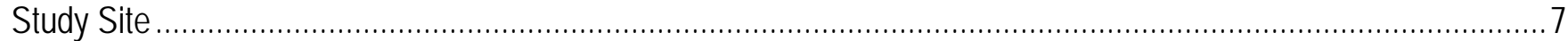

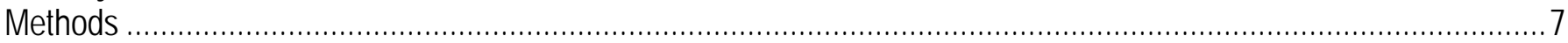

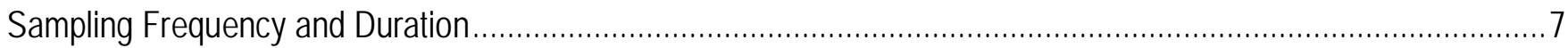

Measurements of Metal Exposure

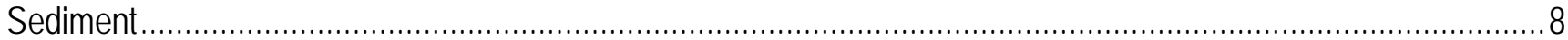

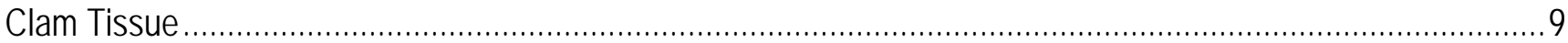

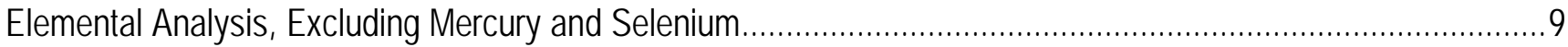

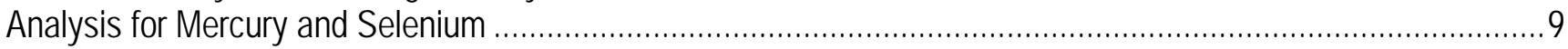

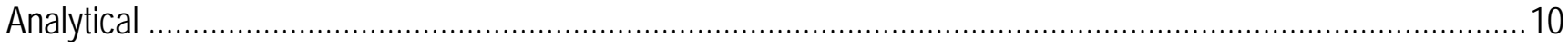

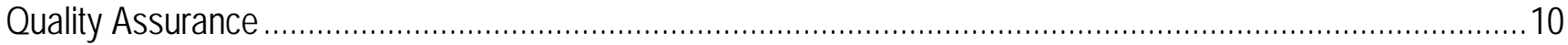

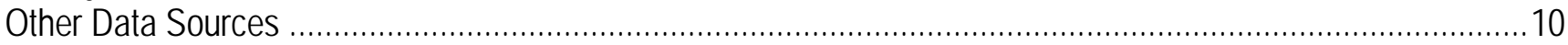

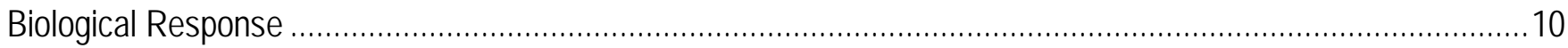

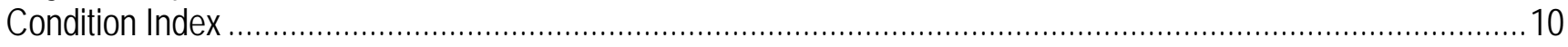

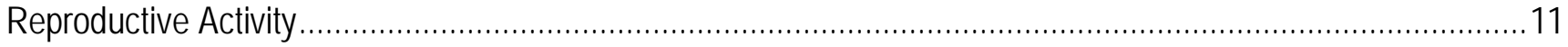

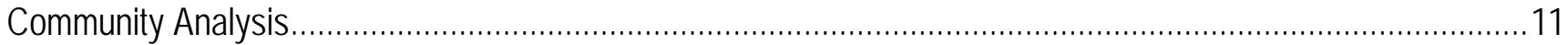

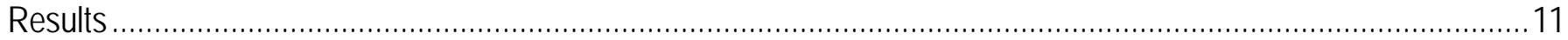

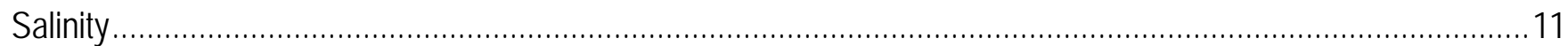

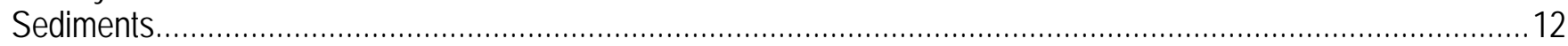

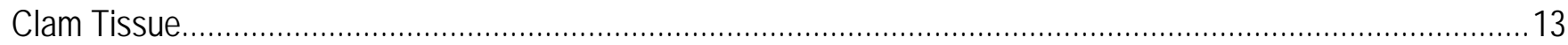

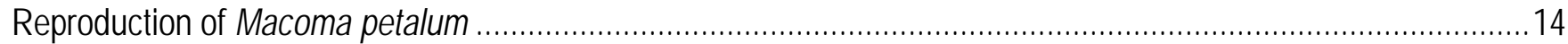

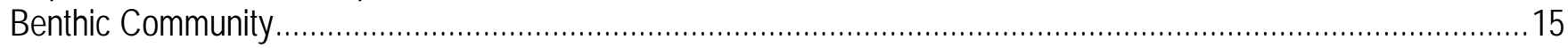

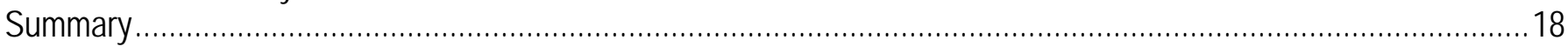

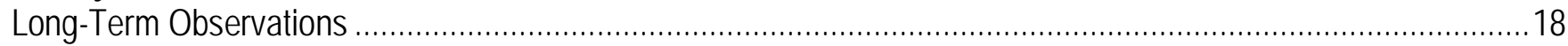

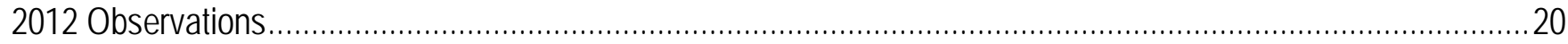

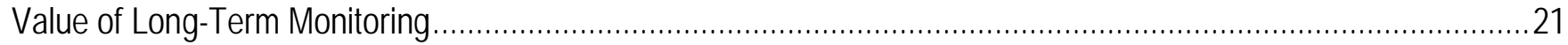

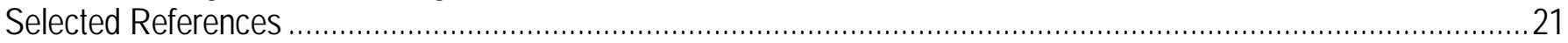

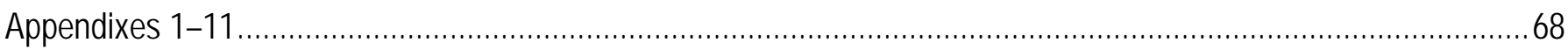

\section{Figures}

1. Location of the Palo Alto sampling site in South San Francisco Bay, Calif. ................................................26

2. Total monthly rainfall recorded at San Francisco WB AP in San Mateo County, Calif., 1994-2012. The station (identification SFF) is operated by the National Weather Service........................................................27

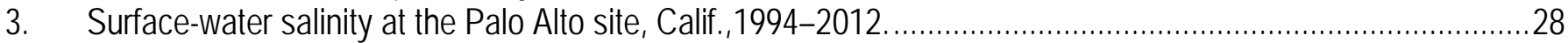

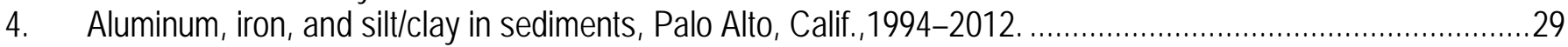

5. Chromium and nickel in sediments, Palo Alto, Calif., 1994-2012 ….........................................................30

6. Copper in sediments, Palo Alto, Calif., 1994-2012. 
7. Zinc in sediments, Palo Alto, Calif., 1994-2012.

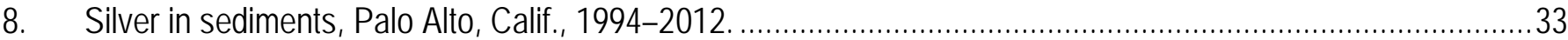

9. Selenium and mercury in sediments, Palo Alto, Calif., 1994-2012 ............................................................34

10. Annual mean copper concentrations in the clam Macoma petalum, Palo Alto, Calif., 1977-2012. ....................35

11. Annual mean silver concentrations in the clam Macoma petalum, Palo Alto, Calif., 1977-2012 .......................36

12. Copper concentrations in the clam Macoma petalum, Palo Alto, Calif., 1994-2012.......................................37

13. Silver concentrations in the clam Macoma petalum, Palo Alto, Calif., 1994-2012 ..........................................38

14. Chromium concentrations in the clam Macoma petalum, Palo Alto, Calif., 1994-2012...................................39

15. Nickel concentrations in the clam Macoma petalum, Palo Alto, Calif., 1994-2012 .......................................40

16. Zinc concentrations in the clam Macoma petalum, Palo Alto, Calif., 1994-2012. .........................................41

17. Mercury concentrations in the clam Macoma petalum, Palo Alto, Calif., 1994-2012 . .....................................42

18. Selenium concentrations in the clam Macoma petalum, Palo Alto, Calif., 1994-2012. ……............................43

19. Condition index of the clam Macoma petalum, Palo Alto, Calif., 1988-2012 .............................................4

20. Reproductive activity of the clam Macoma petalum, Palo Alto, Calif., 1974-2012 .......................................45

21. Reproductive activity of the clam Macoma petalum, Palo Alto, Calif., 2000-2012 .......................................46

22. Total number of species present at the Palo Alto site, Calif., 1974-2012 ....................................................47

23. Total average number of individuals present at the Palo Alto site, Calif., 1974-2012 ....................................4

24. Monthly average abundance of Macoma petalum, Palo Alto, Calif., 1974-2012. .........................................49

25. Monthly average abundance of Mya arenaria, Palo Alto, Calif., 1974-2012 ..................................................50

26. Monthly average abundance of Gemma gemma, Palo Alto, Calif., 1974-2012. ...........................................51

27. Monthly average abundance of Ampelisca abdita, Palo Alto, Calif., 1974-2012 ……………........................52

28. Monthly average abundance of Streblospio benedicti, Palo Alto, Calif., 1974-2012 ......................................53

29. Monthly average abundance of Grandiderella japonica, Palo Alto, Calif., 1974-2012 .....................................54

30. Monthly average abundance of Neanthes succinea, Palo Alto, Calif., 1974-2012.......................................55

31. Monthly average abundance of Heteromastus filiformis, Palo Alto, Calif., 1974-2012 ....................................56

32. Monthly average abundance of Nippoleucon hinumensis, Palo Alto, Calif., 1974-2012 .................................57

33. Reproductive mode annual abundance with silver concentrations in the clam Macoma petalum and in sediment, Palo Alto, Calif., 1974-2012 ..............................................................................................58

34. Reproductive mode annual abundance with copper concentrations in the clam Macoma petalum and in sediment, Palo Alto, Calif., 1974-2012 ………………………....................................................5

35. Feeding mode annual abundance with silver concentrations in the clam Macoma petalum and in sediment, Palo Alto, Calif., 1974-2012.

36. Feeding mode annual abundance with copper concentrations in the clam Macoma petalum and in sediment,

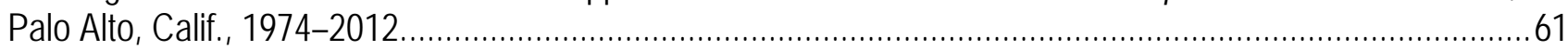

37. Species rank-abundance for the benthic community, Palo Alto, Calif., 2012 ..........................................62

38. Species rank-abundance identified by feeding mode, Palo Alto, Calif., for 1977, 1989, 2002, and 2012. .........63

39. Species rank-abundance data identified by reproductive mode, Palo Alto, Calif., for 1977, 1989, 2002, and 2012.

\section{Tables}

1. Sediment characteristics, salinity, and concentrations of trace metals in sediments, Palo Alto, Calif., 2012 _....65

2. Concentrations of trace metals in the clam Macoma petalum, Palo Alto, Calif., 2012 ……..............................66

3. Reproduction data for Macoma petalum, Palo Alto, Calif., 2012 ...............................................................67 


\section{Conversion Factors}

\begin{tabular}{|l|c|l|}
\hline \multicolumn{1}{|c|}{ Multiply } & By & \multicolumn{1}{c|}{ To obtain } \\
\hline foot (ft) & 0.3048 & meter $(\mathrm{m})$ \\
\hline gallon (gal) & 3.785 & liter $(\mathrm{L})$ \\
\hline inch (in) & 2.54 & centimeter $(\mathrm{cm})$ \\
\hline inch $($ in) & 25,400 & micrometer $(\mu \mathrm{m})$ \\
\hline meter $(\mathrm{m})$ & $1,000,000$ & micrometer $(\mu \mathrm{m})$ \\
\hline mile $(\mathrm{mi})$ & 1.609 & kilometer $(\mathrm{km})$ \\
\hline ounce $(\mathrm{oz})$ & 28.35 & gram $(\mathrm{g})$ \\
\hline part per million $(\mathrm{ppm})$ & 1 & microgram per gram $(\mu \mathrm{g} / \mathrm{g})$ \\
\hline milligram per kilogram $(\mathrm{mg} / \mathrm{kg})$ & 1 & microgram per gram $(\mu \mathrm{g} / \mathrm{g})$ \\
\hline
\end{tabular}

Temperature in degrees Celsius $\left({ }^{\circ} \mathrm{C}\right)$ may be converted to degrees Fahrenheit $\left({ }^{\circ} \mathrm{F}\right)$ as follows:

${ }^{\circ} \mathrm{F}=\left(1.8 \times{ }^{\circ} \mathrm{C}\right)+32$

Temperature in degrees Fahrenheit $\left({ }^{\circ} \mathrm{F}\right)$ may be converted to degrees Celsius $\left({ }^{\circ} \mathrm{C}\right)$ as follows:

${ }^{\circ} \mathrm{C}=\left({ }^{\circ} \mathrm{F}-32\right) / 1.8$

Concentrations of chemical constituents in water are given either in milligrams per liter $(\mathrm{mg} / \mathrm{L})$ or micrograms per liter $(\mu \mathrm{g} / \mathrm{L})$.

NOTE TO USGS USERS: Use of liter (L) as a special name for cubic decimeter $\left(\mathrm{dm}^{3}\right)$ is restricted to the measurement of liquids and gases. No prefix other than milli should be used with liter. 


\section{Abbreviations and Acronyms}

\begin{tabular}{|c|c|}
\hline Abbreviations and Acronyms & Meaning \\
\hline $\mathrm{mL}$ & milliliter \\
\hline$\mu \Omega$ & microohm \\
\hline$\mu \mathrm{g} / \mathrm{g}$ & microgram per gram \\
\hline $\mathrm{mg} / \mathrm{kg}$ & milligram per kilogram \\
\hline$\mu \mathrm{m}$ & micrometer \\
\hline CI & Condition Index \\
\hline ERL & Effects Range-Low \\
\hline ERM & Effects Range-Median \\
\hline ICP-OES & Inductively Coupled Plasma-Optical Emission Spectrophotometry \\
\hline IRMS & Isotopic Ratio Mass Spectrophotometry \\
\hline MDL & Method Detection Limit \\
\hline MLLW & Mean Low Low Water \\
\hline MRL & Method Reporting Level \\
\hline NIST & National Institute of Standards and Technology \\
\hline NPDES & National Pollutant Discharge Elimination System \\
\hline PARWQCP & Palo Alto Regional Water Quality Control Plant \\
\hline RWQCB & California Regional Water Quality Control Board \\
\hline SFEI & San Francisco Estuary Institute \\
\hline USEPA & U.S. Environmental Protection Agency \\
\hline USGS & U.S. Geological Survey \\
\hline
\end{tabular}




\section{Near-Field Receiving Water Monitoring of Trace Metals and a Benthic Community near the Palo Alto Regional Water Quality Control Plant in South San Francisco Bay, California: 2012}

By Jessica L. Dyke, Janet K. Thompson, Daniel J. Cain, Amy E. Kleckner, Francis Parchaso, Samuel N. Luoma, and Michelle I. Hornberger

\section{Executive Summary of Past Findings}

U.S. Geological Survey (USGS) personnel have assessed trace-metal concentrations in sediments and sediment-dwelling species since 1977 at an intertidal site in the vicinity of the discharge of the Palo Alto Regional Water Quality Control Plant (PARWQCP). They have also profiled that area's benthic community structure since 1974. Ancillary biotic and abiotic factors that could affect metal concentrations and benthic community structure (exotic species invasions, pelagic food availability, and weather anomalies) have also been measured during this time.

Initially, these studies found exceptionally high concentrations of copper $(\mathrm{Cu})$ and silver $(\mathrm{Ag})$ in mud-dwelling animals in this area, with strong seasonal variability. Additional studies identified the PARWQCP as a point source for $\mathrm{Cu}$ and $\mathrm{Ag}$ and established the clam Macoma petalum as a biological indicator of metal exposure. The annual mean concentrations of $\mathrm{Cu}$ and $\mathrm{Ag}$ in Macoma petalum were $287 \mathrm{mg} / \mathrm{kg}$ and $105 \mathrm{mg} / \mathrm{kg}$, respectively, in 1980. These levels exceeded tissue concentrations reported in the literature for this species and were much greater than seen elsewhere in San Francisco Bay. Elevated metal concentrations coincided with reduced reproductive activity in $M$. petalum. Related studies supported the theory that elevated Ag concentrations inhibited the development of reproductive tissue. The benthic community also showed signs of environmental stress during this time. The community was dominated by opportunistic animals (organisms capable of fast invasion and spread in disturbed environments) that live on the surface of the mud in tubes or as shelled animals, brood their young, and feed on waterborne particles.

Concentrations of $\mathrm{Cu}$ and $\mathrm{Ag}$ in both sediments and clams declined significantly during the 1980s as the PARWQCP improved its waste treatment facilities and conducted source control programs. The downward trends in $\mathrm{Cu}$ in sediments and in the tissues of $M$. petalum correlated with reduced $\mathrm{Cu}$ discharge from the PARWQCP. Coincident with the decline in $\mathrm{Cu}$ and $\mathrm{Ag}$ in the sediment and clams, the reproductive activity of the clam greatly increased. The composition of the benthic community also shifted during this period. Opportunistic species became less dominant and nonopportunistic species became more persistent. Other environmental factors that vary seasonally and annually (for example, sediment composition, including percent of fine particles, organic content, and salinity) were not associated with the observed temporal trends in metal concentrations, metal effects, and benthic community changes. The only unidirectional change in an environmental factor during this period (1980-1990) was the decline in metals in discharge from the waste treatment plant. 
Following the significant reductions in the 1980s, concentrations of $\mathrm{Cu}$ and $\mathrm{Ag}$ in sediments and clams have remained relatively low and stable. Concentrations have fluctuated modestly and without a sustained temporal trend. However, Ag in sediments remains greater than what may be considered the regional background $(0.09 \mathrm{mg} / \mathrm{kg})$. This persistent, low level of contamination likely derives from $\mathrm{Ag}$ introduced to the site before the 1990s. The concentrations of $\mathrm{Cu}$ and $\mathrm{Ag}$ in $\mathrm{M}$. petalum have fluctuated as much as four-fold. Concentration minima for $\mathrm{Cu}$ observed during this period (1991, 2000-2005, and 2008-2012) were comparable to what can be considered baseline concentrations for this species in San Francisco Bay $(20-30 \mathrm{mg} / \mathrm{kg})$.

Two lines of evidence suggest that the effluent of the PARWQCP is no longer the main driver of temporal patterns in metals at the sampling site. First, since the 1990s, annual variations in $\mathrm{Ag}$ and $\mathrm{Cu}$ in M. petalum have not correlated with discharge of $\mathrm{Cu}$ and $\mathrm{Ag}$ from PARWQCP. Second, temporal patterns in $\mathrm{Ag}$ and $\mathrm{Cu}$ at the site are generally similar to patterns for other major and minor elements that derive from terrigenous inputs and multiple discrete and diffuse anthropogenic sources to South San Francisco Bay. Thus, metal concentrations in sediments and tissue of $M$. petalum are more likely a combination of inputs from the PARWQP and other regional sources, cycling of contaminants stored within South Bay sediments, and regionally-scaled physical and biogeochemical processes controlling the distribution and bioavailability of metals.

As concentrations of $\mathrm{Ag}$ and $\mathrm{Cu}$ in $\mathrm{M}$. petalum declined, reproductive activity increased both in terms of the percentage of individuals that were in a reproductively active stage and the frequency of reproductive activity during the year. Overall, the reproductive status of the population has improved and stabilized over the 20 years of reduced exposure to $\mathrm{Ag}$ and $\mathrm{Cu}$ at the site.

Over the same period, the composition of the infaunal community shifted from a dominance of surface-dwelling, brooding species to species with various life-history characteristics. In particular, species that lay their eggs in the mud and feed by burrowing through and consuming the mud, which were rare in the community in the 1970s and 1980s, have increased in abundance. This pattern continued through 2007, with the less opportunistic species becoming more dominant in abundance. A disturbance occurred on the mudflat in early 2008 (possible causes include sediment accretion or freshwater inundation) that resulted in the loss of the benthic animals, except for those deep-dwelling animals like $M$. petalum. Animals immediately returned to the mudflat, which indicates that the disturbance was not due to a persistent toxin or to anoxia. The use of functional ecology was highlighted in the 2009 benthic community data, which show that the animals that have returned to the mudflat are those that can respond successfully to a physical, nontoxic disturbance. The most recent community surveys show a mix of animals that consume the sediment, filter feed, brood their young, and have pelagic larvae that must survive life on the sediment at a young age. The 2008 defaunation event allowed an examination of the response of the community to a natural disturbance and a comparison of this recovery to the long-term recovery observed in the 1970s, when the decline in sediment pollutants was the dominating factor. Today, the community at this site is very similar to the benthic community observed by Thompson and Parchaso (2012) throughout South Bay: although small filter feeding species are numerically dominant, there is a significant proportion of the community that feeds on surface and subsurface sediment particles. This does not occur when the sediment has a high concentration of toxicants.

When this study started in the late 1970s, the site was already heavily contaminated with metals. Although the authors assume that the biological conditions reflected the consequences of elevated metal exposures, there is a scarcity of preexisting data to evaluate impacts due to elevated metals. However, the long-term record contained in this study provides a unique opportunity to document biological response when the stress of metal exposure is relaxed. The data make a compelling case that the 
mitigation of $\mathrm{Ag}$ and $\mathrm{Cu}$ in waste-water effluent during the 1980s allowed for biological recovery and the establishment of a more diverse and stable infaunal community.

\section{Abstract}

Trace-metal concentrations in sediment and in the clam Macoma petalum (formerly reported as Macoma balthica), clam reproductive activity, and benthic macroinvertebrate community structure were investigated in a mudflat 1 kilometer south of the discharge of the Palo Alto Regional Water Quality Control Plant (PARWQCP) in South San Francisco Bay, Calif. This report includes the data collected by U.S. Geological Survey (USGS) scientists for the period January to December 2012. These data serve as the basis for the City of Palo Alto's Near-Field Receiving Water Monitoring Program, initiated in 1994.

Following significant reductions in the late 1980s, silver $(\mathrm{Ag})$ and copper $(\mathrm{Cu})$ concentrations in sediment and in M. petalum appear to have stabilized. Data for other metals, including chromium $(\mathrm{Cr})$, mercury (Hg), nickel (Ni), selenium (Se), and zinc (Zn), have been collected since 1994. Over this period, concentrations of these elements have remained relatively constant, aside from seasonal variation that is common to all elements. In 2012, concentrations of $\mathrm{Ag}$ and $\mathrm{Cu}$ in $\mathrm{M}$. petalum varied seasonally in response to a combination of site-specific metal exposures and annual growth and reproduction, as reported for previous time periods. Seasonal patterns for other elements, including $\mathrm{Cr}$, $\mathrm{Ni}, \mathrm{Zn}, \mathrm{Hg}$, and Se were generally similar in timing and magnitude as those for Ag and $\mathrm{Cu}$. In 2012, metal concentrations in both sediments and clam tissue were among the lowest concentrations on record. This record suggests that regional-scale factors now largely control sedimentary and bioavailable concentrations of $\mathrm{Ag}$ and $\mathrm{Cu}$, as well as other elements of regulatory interest, at the Palo Alto site.

Analyses of the benthic community structure of a mudflat in South San Francisco Bay over a 39year period show that changes in the community have occurred concurrent with reduced concentrations of metals in the sediment and in the tissues of the biosentinel clam, M. petalum, from the same area. Analysis of the $M$. petalum community shows increases in reproductive activity concurrent with the decline in metal concentrations in the tissues of this organism. Reproductive activity is presently stable (2012), with almost all animals initiating reproduction in the fall and spawning the following spring. The community has shifted from being dominated by several opportunistic species to a community where the species are more similar in abundance, a pattern that indicates a more stable community that is subjected to fewer stressors. In addition, two of the opportunistic species (Ampelisca abdita and Streblospio benedicti) that brood their young and live on the surface of the sediment in tubes have shown a continual decline in dominance coincident with the decline in metals; both species had shortlived rebounds in abundance in 2008, 2009, and 2010. Heteromastus filiformis (a subsurface polychaete worm that lives in the sediment, consumes sediment and organic particles residing in the sediment, and reproduces by laying its eggs on or in the sediment) showed a concurrent increase in dominance and, in the last several years before 2008, showed a stable population. $H$. filiformis abundance increased slightly in 2011-2012. An unidentified disturbance occurred on the mudflat in early 2008 that resulted in the loss of the benthic animals, except for those deep-dwelling animals like Macoma petalum. Animals immediately returned to the mudflat in 2008, which was the first indication that the disturbance was not due to a persistent toxin or to anoxia. The reproductive mode of most species present in 2012 is reflective of the species that were available either as pelagic larvae or as mobile adults. Although oviparous species were lower in number in this group, the authors hypothesize that these species will return slowly as more species move back into the area. The use of functional ecology was highlighted in the 2012 benthic community data, which show that the animals that have now returned to the mudflat 
are those that can respond successfully to a physical, nontoxic disturbance. Today, community data show a mix of animals that consume the sediment, filter feed, have pelagic larvae that must survive landing on the sediment, and brood their young. USGS scientists continue to observe the community's response to the 2008 defaunation event because it allows them to examine the response of the community to a natural disturbance (possible causes include sediment accretion or freshwater inundation) and compare this recovery to the long-term recovery observed in the 1970s when the decline in sediment pollutants was the dominating factor.

\section{Introduction}

Determining spatial distributions and temporal trends in trace metals in sediments and benthic organisms is common practice for monitoring environmental contamination. These data can be the basis for inferring ecological implications of metal contamination. Another common method of environmental monitoring is to examine the community structure of sediment-dwelling benthic organisms (Simon, 2002). Spatial and temporal changes in community structure reflect the response of resident species to environmental conditions, although the underlying cause(s) for the response may be difficult to identify and quantify. Integrating measurements of metal exposure and biological response can provide a more complete view of anthropogenic disturbances and the associated effects on ecosystem health.

\section{Environmental Exposure to Trace Metals}

Sediment particles can strongly bind metals, effectively removing them from solution. As a result, sediments may accumulate and retain metals released to the environment. Contaminated sediments may become a chronic source of metals to the environment. Thus, concentrations of metals in sediments serve as a record of metal contamination in an estuary, with some integration over time. Fluctuations in the record may be indicative of changes in anthropogenic releases of metals into the environment.

Metals in sediments are also indicative of the level of exposure of benthic animals to metals through contact with, and ingestion of, bottom sediments and suspended particulate materials. However, geochemical conditions of the sediment affect the biological availability of the bound metals. Assimilation of bioavailable sediment-bound metal by digestive processes and the relative contribution of this source of metals relative to metals in the aqueous phase are not well understood. Thus, in order to better estimate bioavailable metal exposures, the tissues of the organisms themselves may be analyzed for trace metals. Benthic organisms concentrate most metals to levels higher than those that occur in solution. Therefore, the record of metal concentrations in clam tissue can be a more sensitive indicator of anthropogenic metal inputs than the sediment record. Different species concentrate metals to different degrees. However, if one species is analyzed consistently, the results can be used to indicate traceelement exposures to the local food web.

\section{Biological Response to Trace Metals}

Contaminants can adversely affect benthic organisms at several organizational levels. For example, responses to a pollutant at the cellular or physiological level of an individual can result in changes at the population level, such as reductions in growth, survival, and reproductive success. Community level responses to population level impairment can include overall shifts in species abundance, favoring metal-tolerant species, which can result in changes in predator/prey interactions and competition for available resources. Changes in the benthic community can ultimately result in changes at the ecosystem level due to that community's importance in the cycling of carbon in aquatic environments (Alpine and Cloern, 1992, provides a local example). 
In all aquatic environments, benthic organisms may be exposed to contaminants at all life stages through a variety of routes - sediment, water, and food (Wang and Fisher, 1999, provides a summary of the potential transport of trace elements through food). Toxicant exposure is related to contaminant concentration as well as duration. Even at low contaminant levels, long-term exposure can affect benthic organisms. The added complexity of synergistic or antagonistic effects between different contaminants, and between contaminants and natural stressors, makes causal relationships difficult to identify and quantify, even on a site-specific basis. However, a time-integrated picture of ecosystem response to contaminant loading can be provided by field studies that link changes in exposure at multiple time scales (in this case seasonal to decadal) to changes at individual, population, and community levels.

\section{RWQCB and NPDES}

The California Regional Water Quality Control Board (RWQCB) has prescribed a Self Monitoring Program with its reissuance of the National Pollutant Discharge Elimination System (NPDES) permits for South San Francisco Bay dischargers. The recommendation includes specific receiving-water monitoring requirements.

Since 1994, the Palo Alto Regional Water Quality Control Plant (PARWQCP) (fig. 1) has been required to monitor metals and other specified parameters in sediments and the clam M. petalum at an inshore location in South San Francisco Bay, Calif. In addition to the required monitoring, PARWQCP has undertaken monitoring of the benthic community as a whole. The monitoring protocols have been designed to be compatible with or complement the RWQCB's Regional Monitoring Program. Monitoring efforts are being conducted by the U.S. Geological Survey (USGS) and are coordinated with more than 30 years of previous data collections and investigations by the USGS at this inshore location.

\section{Objectives}

The data collected during this study include trace-metal concentrations in sediments and clams, clam reproductive activity, and benthic community structure. These data and those reported earlier (for example, Hornberger and others, 2000a; Luoma and others, 1991, 1995a, 1996; Moon and others, 2005; Shouse and others, 2003, 2004; Thompson and others, 2002; Cain and others, 2006; Dyke and others, 2011, 2012) were used to meet the following objectives:

- Provide data to assess seasonal and annual trends in trace-element concentrations in sediments and clams, reproductive activity of clams, and benthic community structure at a site designated in the RWQCB's Self-Monitoring Program guidelines for PARWQCP.

- Present the data within the context of historical changes in South San Francisco Bay and within the context of other locations in the Bay published in the international literature.

- Coordinate inshore receiving water monitoring programs for PARWQCP and provide data compatible with relevant aspects of the Regional Monitoring Program. The near-field data will augment the Regional Monitoring Program as suggested by the RWQCB.

- Provide data that could support other South San Francisco Bay issues or programs, such as development of sediment quality standards.

\section{Approach}

Despite the complexities inherent in monitoring natural systems, the adopted approach has been effective in relating changes in near-field contamination to changes in reproductive activity of a clam (Hornberger and others, 2000b) and in benthic community structure (Kennish,1998). This study, with its basis in historical data, provides a context within which future environmental changes can be assessed.

Metal concentrations were monitored in sediments and a resident clam species, Macoma petalum. Analysis of trace-metal concentrations in the sediments provides a record of metal 
contamination of the site. The concentration and bioavailability of sediment-bound metals are affected by hydrology and geochemical factors (Thomson-Becker and Luoma, 1985; Luoma and others, 1995b). Thus, ancillary data, including grain-size distribution, organic carbon, aluminum and iron content of the sediment, regional rainfall, and surface salinity were collected to interpret seasonal, annual, and interannual variation in metal concentrations. The tissue of $M$. petalum provides a direct measure of exposure to bioavailable metals.

Biological response of the benthic community to metal exposure was examined at three levels of organization: individual, population, and community. At the individual level, concentrations of metals in the tissues of $M$. petalum were compared with physiological indicators. Two common animal responses to environmental stress are reduced reproductive activity and reduced growth. Growth and reproduction in $M$. petalum occur on fairly regular seasonal cycles. Seasonally, a clam of a given shell length will increase somatic tissue weight as it grows during the late winter and spring. Reproductive tissue increases during the early stages of reproduction and subsequently declines during and after reproduction. These cycles can be followed with the condition index (CI), which is an indicator of the physiological condition of the animal and, specifically, is the total soft-tissue weight of a clam standardized to shell length. Interannual differences in growth and reproduction, expressed in the CI, are affected by the availability and quality of food, as well as other stressors, such as pollutant exposure and salinity extremes. An earlier study (Hornberger and others, 2000b) has shown that reproductive activity of $M$. petalum has increased with declining metal concentrations in animals from this location. Therefore, $\mathrm{CI}$ and reproductive activity of $M$. petalum appear to be useful indicators of physiological stress by pollutants at this location and continue to be monitored for this study.

At the population level, trends of the dominant benthic species were examined to see if certain species have been more affected than others by environmental change. It has been shown that most taxonomic groups have species that are sensitive to elevated Ag (Luoma and others, 1995b) and that some crustacean and polychaete species are particularly sensitive to elevated sedimentary $\mathrm{Cu}$ (Morrisey and others, 1996; Rygg, 1985). In addition, the benthic community was examined for changes in structure: that is, shifts in the species composition of the macroinvertebrate community resulting in a change in the function of the community. The authors hypothesized that a shift in community composition and potentially in the function of the benthic community in the ecosystem would result from changes in the concentrations of specific metals or from a composite of all contaminants for several reasons. First, prior studies have shown that South Bay benthic communities were dominated by opportunistic species in the 1980s (Nichols and Thompson, 1985a). These opportunistic species might become less dominant as environmental stressors decrease. Second, environmental pollutants may differentially affect benthic species that use different feeding and reproductive modes. An intertidal mudflat community, such as this study site, should include a combination of species that feed on particles in the water column, on settled and buried food particles in the mud, and on other organisms. The absence of any one of these feeding groups may show limitations on species as a result of environmental stressors that target specific feeding groups. For example, pollutants attached to sediment particles are more likely to affect species that consume the sediment as part of their feeding mode or those species that lay their eggs in the sediment.

Previous analysis of this community has shown no correlation between changes in the community and measured environmental parameters (salinity, air and water temperature, delta outflow, precipitation, chlorophyll $a$, sediment total organic carbon, and biological oxygen demand; Shouse, 2002). Therefore, the community data are compared only to trace-metal data in this report. 


\section{Study Site}

The Palo Alto site (PA) includes the benthic community sampling site and the M. petalum and sediment sampling site, both adjacent to Sand Point in Palo Alto Baylands Park on a mudflat on the western shore of San Francisco Bay (not a slough) (fig. 1). The site is 1 kilometer southeast of the intertidal discharge point of the PARWQCP. The sampling locations are approximately 12 meters $(\mathrm{m})$ from the edge of the marsh and 110 centimeters $(\mathrm{cm})$ above mean low low water (MLLW).

The sediment and biological samples from this location reflect a response of the receiving waters to the effluent just beyond the location of discharge. Earlier studies (Thomson and others, 1984) have shown that dyes, natural organic materials in San Francisquito Creek, and waters in the PARWQCP discharge move predominantly south toward Sand Point and, thereby, affect the mudflats in the vicinity of Sand Point. Spatial distributions of metal concentrations near the PARWQCP site were described by Thomson and others (1984), who showed that San Francisquito Creek and the Palo Alto Yacht Harbor were minor sources of most trace elements compared to the PARWQCP. The PARWQCP appeared to be the primary source of the elevated metal concentrations at the PA site in the spring of 1980, on the basis of spatial and temporal trends of $\mathrm{Cu}, \mathrm{Ag}$, and zinc $(\mathrm{Zn})$ in clams and sediments (Thomson and others, 1984; Cain and Luoma, 1990). Metal concentrations in sediments and clams (M. petalum), especially $\mathrm{Cu}$ and $\mathrm{Ag}$, have declined substantially since the original studies, as more efficient treatment processes and source controls were employed (Hornberger and others, 2000b). Frequent sampling each year was necessary to characterize those trends because there was significant seasonal variability (Cain and Luoma, 1990; Luoma and others, 1985). This report characterizes data for the year 2012, employing the methods described in the succeeding section.

Previous reports (Luoma and others, 1995a, 1996, 1997, 1998; Wellise and others, 1999) also included data for a site in South San Francisco Bay that was influenced by discharge from the San Jose/Santa Clara Water Pollution Control Plant. Samples were collected from this site from 1994 to September 1999. Comparison of data from this site and the Palo Alto site allowed differentiation of local and regional long-term metal trends.

\section{Methods}

\section{Sampling Frequency and Duration}

In dynamic ecosystems such as San Francisco Bay, the environmental effects of anthropogenic stressors are difficult to distinguish from natural seasonal changes. Sustained sampling at frequent intervals can characterize seasonal patterns, capture episodic events, and identify longer term trends, thereby increasing the probability that anthropogenic effects can be identified. Analyses of early community data (1974 through 1983; Nichols and Thompson, 1985a, 1985b) showed that benthic samples need to be collected at monthly to bimonthly intervals to distinguish between natural and anthropogenic effects. Therefore, data reported herein are based on samples collected, with a few exceptions, on a monthly basis from the exposed mudflat at low tide between January and December, 2012. Samples collected in the field include surface sediment, the deposit-feeding clam M. petalum, surface water, and sediment cores for community analysis. Surface water, surface sediment, and $M$. petalum were not collected during the months of July, August, and November. Cores for benthic community analyses were not collected during the months of October, November, and December. Data on sediments, $M$. petalum, and surface water have been collected continuously since 1977, while community data were collected during 1974-1990 and 1998 to the present (2012). 


\section{Measurements of Metal Exposure}

\section{Sediment}

Sediment samples were scraped from the visibly oxidized (brownish) surface layer (top 1-2 cm) of mud. This surface layer represents recently deposited sediment and detritus, or sediment affected by recent chemical reactions with the water column. The sediment also supports microflora and fauna, a nutritional source ingested by $M$. petalum. Sediment samples were immediately taken to the laboratory and sieved through a 100-micrometer $(\mu \mathrm{m})$ mesh polyethylene screen with distilled water to remove large grains that might bias interpretation of concentrations. The mesh size was chosen to match the largest grains typically found in the digestive tract of $M$. petalum. All sediment data reported herein were determined from the fraction that passed through the sieve $(<100 \mu \mathrm{m})$, termed the "silt/clay fraction." Previous studies have shown little difference between metal concentrations in sieved and unsieved sediments when silt/clay-type sediment dominates at a site. However, where sand-size particles dominate the bed sediment, differences in metal concentrations can be substantial. Sediments in extreme South San Francisco Bay can vary spatially and temporally in their sand content (Dyke and others, 2011). Where sand content varies, sieving reduces the likelihood that differences in metal concentrations are the result of sampling sediments of different grain size. Some differences between the USGS and the Regional Monitoring Program results (San Francisco Estuary Institute, 1997) reflect the bias of particle size on the latter's data.

To provide a measure of bulk sediment characteristics at a site and, thus, provide some comparability with bulk sediment determinations such as that employed in the Regional Monitoring Program (San Francisco Estuary Institute, 1997), the fraction of sediment that did not pass through the sieve $(\geq 100 \mu \mathrm{m})$ was determined. This fraction is termed the sand fraction. Bulk sediment samples were sieved to determine the percent sand and percent silt/clay $(<100 \mu \mathrm{m})$ (appendix 1, table 1). The percentage of the bulk sediment sample composed of sand-size particles (percent sand) was determined by weighing the fraction of sediment that did not pass through the sieve $(\geq 100 \mu \mathrm{m})$, dividing that weight by the total weight of the bulk sample, and multiplying the quotient by 100 . The percentage of silt/clay in the sediment was determined similarly by weighing the sediment that passed through the sieve (grain size $<100 \mu \mathrm{m})$.

The silt/clay fraction was dried at 60 degrees Celsius $\left({ }^{\circ} \mathrm{C}\right)$, weighed, and then subsampled to provide replicates weighing 0.4 to $0.6 \mathrm{~g}$. These were redried $\left(60^{\circ} \mathrm{C}\right)$, reweighed, and then digested by hot acid reflux (10 milliliters $(\mathrm{mL})$ of 16 normal $(\mathrm{N})$ nitric acid) until the digest was clear. This method provides a "near-total" extraction of metals from the sediment and is comparable to the recommended procedures of the U.S. Environmental Protection Agency (USEPA) and to the procedures employed in the Regional Monitoring Program. It also provides data comparable to the historical data available on San Francisco Bay sediments. Although near-total analysis does not result in 100-percent recovery of all metals, recent comparisons between this method and more rigorous complete decomposition show that trends in the two types of data are very similar (Hornberger and others, 1999). After extraction, samples were evaporated until dry, then reconstituted in dilute hydrochloric acid (10 percent or $0.6 \mathrm{~N})$. The hydrochloric acid matrix was specifically chosen because it mobilizes Ag into solution through the creation of Ag-chloro-complexes. Sediment extracts were allowed to equilibrate with the hydrochloric acid (minimum of 48 hours) before they were filtered $(0.45 \mu \mathrm{m})$ into acid-washed polystyrene vials for elemental analysis. Another set of replicate subsamples from the silt/clay fraction were directly extracted with $12 \mathrm{~mL}$ of $0.6 \mathrm{~N}$ hydrochloric acid $(\mathrm{HCl})$ for 2 hours at room temperature. This partial extraction method extracts metals bound to sediment surfaces and is operationally designed to obtain a crude chemical estimate of bioavailable metal. The extract was pressure filtered $(0.45 \mu \mathrm{m})$ before elemental analysis. 
Total organic carbon (TOC) concentration was determined using a continuous flow isotope ratio mass spectrophotometer (IRMS) (table 1). Before the analysis, sediment samples were acidified with 12 $\mathrm{N} \mathrm{HCl}$ vapor to remove inorganic carbon (method described by Harris and others, 2001).

Water pooled on the surface of the mudflat was collected in a bottle and returned to the laboratory, where it was measured for salinity with a handheld refractometer.

\section{Clam Tissue}

Specimens of $M$. petalum were collected by hand on each sampling occasion. Typically, 60-120 individuals were collected, representing a range of sizes (shell length). As they were collected, the clams were placed into a screw-cap polypropylene container (previously acid-washed) containing site water. These containers were used to transport the clams to the laboratory.

In the laboratory, the clams were removed from the containers and gently rinsed with deionized water to remove sediment. A small amount of mantle water was collected from randomly selected clams for the determination of salinity with a refractometer. The salinity of the mantle water and the surface water collected from the site were typically within 1 part per thousand (ppt) of each other. Only surface water values are reported here. Natural sand-filtered seawater (obtained from U.C. Santa Cruz, Long Marine Labs, Santa Cruz, California) was diluted with deionized water to the measured salinity of the site water. Clams were immersed in this water and moved to a constant temperature room $\left(12^{\circ} \mathrm{C}\right)$ for 48 hours to allow for the egestion of sediment and undigested material from their digestive tracts. Clams were not fed during this depuration period. After depuration, the clams were returned to the laboratory and further prepared for chemical analysis.

\section{Elemental Analysis, Excluding Mercury and Selenium}

The shell length of each clam was measured with electronic calipers and recorded digitally. Clams were separated into 1- or 2-millimeter (mm) size classes (for example, 10.00-10.99 mm or 10.00-11.99 mm). The soft tissues from all of the individuals within a given size class were dissected from the shell and collected in preweighed 20-mL screw-top borosilicate glass vials to form a single composite sample for elemental analysis. The sample for each collection was thus composed of 9 to 13 composites, with each composite consisting of 1 to 35 clams of a similar shell length. The vials were capped with a glass reflux bulb and transferred to a convection oven $\left(70^{\circ} \mathrm{C}\right)$. After the tissues were dried to constant weight, they were digested by reflux in subboiling $16 \mathrm{~N}$ nitric acid. The tissue digests were then dried and reconstituted in $0.6 \mathrm{~N}$ hydrochloric acid for trace-metal analysis.

\section{Analysis for Mercury and Selenium}

Samples collected during winter (December, January, and February), spring (April), and summer (June and September) were analyzed for total mercury $(\mathrm{Hg})$ and selenium $(\mathrm{Se})$. Approximately $40 \mathrm{clams}$ were selected from the collection. The only criterion for selection was that the range of sizes (shell length) within this group was representative of the larger collection. Otherwise, the selection of individuals was random. Selected individuals were grouped according to size to form 3 composites, each containing a minimum of $\sim 1.25 \mathrm{~g}$ wet weight. To meet this requirement, especially for the smaller clams, the 1-mm size classes were usually combined to form broader size classes (within 3-4 mm of each other, as appropriate). Once the composites were formed, the clams were dissected as described above, and the soft tissue was placed into preweighed 30-mL screw-top polycarbonate vials. These vials were closed and transferred to a freezer $\left(\right.$ at $\left.-20^{\circ} \mathrm{C}\right)$. Once frozen, the samples were freeze-dried. Freezedried samples were analyzed for total mercury by acid-digestion, $\mathrm{BrCl}$ oxidation, purge and trap, and cold vapor atomic fluorescence spectrometry, according to the EPA Method1631, Revision E (U.S. Environmental Protection Agency, 2002), and for selenium by acid digestion, hydrogen peroxide 
oxidation, and hydride generation inductively coupled plasma mass spectrometry (HG-ICP-MS), according to a method modified from Liber (2011) and Elrick \& Horowitz (1985).

\section{Analytical}

Sediment and tissue concentrations of aluminum (Al), chromium $(\mathrm{Cr})$, copper $(\mathrm{Cu})$, iron $(\mathrm{Fe})$, nickel (Ni), silver ( $\mathrm{Ag})$, and zinc ( $\mathrm{Zn})$ were determined using Inductively Coupled Plasma Optical Emission Spectrophotometry (ICP-OES). Analytical results are included in appendixes 2-4.

\section{Quality Assurance}

The polypropylene containers used in the field, depuration containers, glass-reflux bulbs, and all glassware and plastic used for metal analysis were first cleaned to remove contamination. Cleaning consisted of a detergent wash and rinse in deionized water, followed with a 10-percent hydrochloricacid wash and thorough rinse in double-deionized water (approximately 18 mega-ohm (M $\Omega$ ) resistivity). Materials were dried in a dust-free positive-pressure environment, sealed, and stored in a dust-free cabinet.

Samples prepared for ICP-OES analysis (that is, all elements except Se and $\mathrm{Hg}$ ) were accompanied by procedural blanks and standard reference materials issued by the National Institute of Standards and Technology (NIST). Analysis was preceded by instrument calibration, followed by quality-control checks with prepared quality-control standards before, during (approximately every 10 samples), and after each analytical run. Analyses of reference materials (NIST 2709a, San Joaquin soils, and NIST 2976, mussel tissue) were consistent for the method and were mostly within the range of certified values reported by NIST; however, recovery of Al in NIST 2709a was relatively lower than other metals while recovery of vanadium (V) was relatively high (appendix 5). Recoveries of $\mathrm{Ni}$ and $\mathrm{Pb}$ in NIST 2976 tended to be less than the certified concentrations (appendix 6). Method detection limits (MDL) and reporting levels (MRL) were determined using the procedures outlined by Glaser and others (1981), Childress and others (1999), and U.S. Environmental Protection Agency (2004) (appendix 7). A full quality-assurance/quality-control plan is available upon request.

A variety of standard reference materials were prepared according to the method used for the determination of Se and $\mathrm{Hg}$. Observed concentrations fell within the range of certified values for these materials (appendix 8).

\section{Other Data Sources}

Precipitation data (fig. 2) for San Francisco Bay are reported from a station at San Francisco International Airport (station identification SFF) and were obtained from the California Data Exchange Center (http://cdec.water.ca.gov/).

\section{Biological Response}

\section{Condition Index}

The condition index (CI) is a measure of the clam's physiological state derived from the relation between soft tissue weight and shell length and reported as the soft tissue dry weight (grams) for a clam of a particular shell length ( $\mathrm{mm})$. Specifically, for each collection, the relation between the average shell length and tissue dry weight of the composites was fit with a linear regression, and from that regression, the tissue dry weight was predicted for a normalized shell length of $25 \mathrm{~mm}$. 


\section{Reproductive Activity}

A minimum of 10 clams of varying sizes (minimum of $10 \mathrm{~mm}$ ) were processed for reproductive activity concurrent with samples for metal analyses. Clams were immediately preserved in 10-percent formalin at the time of collection. The visceral mass of each clam was removed in the laboratory, stored in 70-percent ethyl alcohol, and then prepared using standard histological techniques. Tissues were dehydrated in a graded series of alcohol, cleared in toluene (twice for 1 hour each), and infiltrated in a saturated solution of toluene and Paraplast ${ }^{\circledR}$ for 1 hour, and two changes of melted Tissuemat ${ }^{\circledR}$ for 1 hour each. Samples were embedded in Paraplast ${ }^{\circledR}$ in a vacuum chamber and then thin sectioned $(10 \mu \mathrm{m})$ using a microtome (Weesner, 1960). Sections were stained with Harris' hematoxylin and eosin and examined with a light microscope. Each individual was characterized by size (length in $\mathrm{mm}$ ), sex, developmental stage, and condition of gonads, thus allowing each specimen to be placed in one of five qualitative classes of gonadal development (previously described by Parchaso, 1993).

\section{Community Analysis}

Samples for benthic community analysis were collected with hand-held core $8.5-\mathrm{cm}$ in diameter and $20-\mathrm{cm}$ deep. Three replicate samples were taken arbitrarily, within a square-meter area, during each sampling date.

Benthic community samples were washed on a $500-\mu \mathrm{m}$ screen, fixed in 10-percent formalin, and then later preserved in 70-percent ethanol. Samples were stained with rose bengal solution. All animals in all samples were sorted to species level where possible (some groups, such as the oligochaetes, are still not well defined in the Bay), and individuals for each species were enumerated. Taxonomic work was performed in conjunction with a private contractor familiar with the taxonomy of San Francisco Bay invertebrates (Susan McCormick, Colfax, California) (appendix 10). McCormick also compared and verified her identifications with previously identified samples.

\section{Results}

\section{Salinity}

Surface-water salinity in San Francisco Bay is related to the seasonal weather pattern in Northern California, which is characterized by a winter rainy season that has been defined as months with rainfall amounts greater than 0.25 inches (November through April) and a summer dry season (May through October) (fig. 2). The average annual rainfall during the period of record (1994-2012) is 23.2 inches. Rainfall during 2012 was above average at 24.8 inches. Rainfall in early 2012 (JanuaryFebruary) was below average (2.82 inches). Above average rainfall occurred in March 2012 (5.97 inches) and also in November-December, with a cumulative total for the year of 11.6 inches.

Surface-water salinity typically exhibits a seasonal pattern that is the inverse of regional rainfall (fig. 3, table 1). This general pattern was again observed in 2012. Salinity started out fairly high at the beginning of the year, reaching its maximum in February at $30 \mathrm{ppt}$, likely because of lower than average precipitation in late 2011. High March-April rainfall caused a drop in salinity, which bottomed out in May at 22 ppt. It climbed back up to $29 \mathrm{ppt}$ in September, then dropped sharply to $20 \mathrm{ppt}$ in December as massive rainstorms hit the region. The range of salinity in 2012 was close to average for the period of record. The tight salinity range during 2007-2009 coincided with 3 consecutive years of low total precipitation. The above average rainfall in 2010 and for the first half of 2011 likely contributed to the larger salinity range seen in 2011. The lowest spring declines in salinity in this record were during the period 1995-2000 and again in 2006, when salinity minima were 10 ppt or less. 


\section{Sediments}

Metal concentrations in surface sediments from Palo Alto typically display an annual periodicity of seasonal patterns that generally corresponds to the relative abundance of fine particles (figs. $4 C-8 C$ ). Thomson-Becker and Luoma (1985) suggest that this intraannual variation is related to changes in the size distribution of sediment particles caused by deposition of fine-grained particles in the winter and their subsequent wind-driven resuspension in the summer and fall. The weight-normalized concentrations of metals bound to the surfaces of sediments $(\mu \mathrm{g} / \mathrm{g})$ vary with the ratio of surface area to volume of a particle. Thus, metal concentrations tend to increase as particle size decreases. ThomsonBecker and Luoma (1985) showed that surface sediments were dominated by fine-grained particles, accompanied by high $\mathrm{Al}$ and $\mathrm{Fe}$ concentrations, during the period of freshwater input (low salinities through April), reflecting annual terrigenous sediment inputs from runoff. Coarser sediments dominated later in the year, because the seasonal diurnal winds progressively mix the water and the put fine sediments into suspension and transport through the summer. This typical seasonal pattern of variation in sediment properties was mostly repeated in 2012 (fig. 4, appendix 1). The percentage of silt/clay in the sediment steadily increased from 52 percent in October 2011 to 91 percent in February 2012, following the onset of winter rains. Fine-grained sediment percentage dropped a bit in March-April, then peaked in May at 94 percent. The concentrations of $\mathrm{Al}$ and Fe followed the same general trend as the silt/clay size particles (maximum concentrations occurred in May) (fig. 4, table 1), as described above, reflecting the contribution of clays rich in $\mathrm{Al}$ and $\mathrm{Fe}$.

Surface sediments from Palo Alto in 2012 contained about 1.18 percent (by weight) total organic carbon (TOC) (table 1). Carbon content varied slightly during the year and, in general, followed the changes in silt/clay percentage. September was anomalous - TOC reached its annual maximum (1.44 percent) while the percentage of silt/clay was low (61 percent). TOC was lowest in June at 0.94 percent.

The metals chromium $(\mathrm{Cr})$ and nickel (Ni) are highly enriched in some geologic formations within the watershed. In North San Francisco Bay, studies of sediment cores indicated that concentrations of these elements similar to those reported here were derived from natural geologic inputs (Hornberger and others, 1999; Topping and Kuwabara, 2003). Inputs of minerals bearing $\mathrm{Cr}$ and $\mathrm{Ni}$ appear to vary seasonally, as indicated by the varying concentrations of these metals in surface sediments. Typically, maximum concentrations coincide with winter/spring maxima in fine sediments, whereas minimum concentrations occur during the late summer/fall (fig. 5, table 1). The minimum 2012 concentrations of $\mathrm{Cr}$ and $\mathrm{Ni}$ occurred in the fall $(95.8 \mathrm{mg} / \mathrm{kg}$ and $50.8 \mathrm{mg} / \mathrm{kg}$, respectively, in September). Both elements (Cr and $\mathrm{Ni})$ reached annual maxima in May of $2012(142 \mathrm{mg} / \mathrm{kg}$ and 81.5 $\mathrm{mg} / \mathrm{kg}$, respectively). These values coincide with highest annual silt/clay percentage, also in May. The concentration range and timing of variation is typical of the record (1994-2012) for both $\mathrm{Cr}$ and $\mathrm{Ni}$. Average concentrations of $\mathrm{Cr}$ tended to increase during 2006-2010, approaching the record high $\mathrm{Cr}$ concentrations in 2003; this trend was not sustained in 2011-2012.

Concentrations of $\mathrm{Cu}$ and $\mathrm{Zn}$ in sediments are shown with sediment guidelines set by the National Oceanic and Atmospheric Administration (Long and others, 1995) in figures 6 and 7 and table 1. Long and others (1995) defined values between ERL (Effects Range-Low) and ERM (Effects RangeMedian) as concentrations that are occasionally associated with adverse effects on sensitive species (2147 percent of the time for different metals). Values greater than the ERM were frequently associated with adverse effects on sensitive species (42-93 percent of the time for different metals). It is important to note, however, that these effects levels were derived mostly from bioassay data and are not accurate estimates of site-specific sediment toxicity. During 2006-2007, Cu concentrations increased to concentrations similar to those observed before 2000, apparently reversing a trend of declining concentrations during the intervening years. During 2008-2012, Cu concentrations decreased from 
2006-2007 values and were only slightly higher than those observed during 2000-2005. In 2012, Cu concentrations remained above the ERL ( $34 \mathrm{mg} / \mathrm{kg}$ ) from January through June, dipped below the ERL in September, and were back to the ERL level in October-December. The typical seasonal pattern was evident, with the exception of a dip in $\mathrm{Cu}$ in April $(38.6 \mathrm{mg} / \mathrm{kg})$ before $\mathrm{Cu}$ concentrations peaked in May (48.6 mg/kg), then fell to the annual minimum in September (27.8 mg/kg) (fig. 6, table 1). The higher partial-extractable $\mathrm{Cu}$ concentrations in 2011-2012 appear to reverse the slight downward trend observed from 2006 to 2010. Partial-extractable and near-total $\mathrm{Zn}$ concentrations were below the $\mathrm{Zn}$ ERL (150 mg/kg) for all of 2012 (fig. 7, table 1). Zinc peaked in May at $143 \mathrm{mg} / \mathrm{kg}$ and bottomed out at $83.3 \mathrm{mg} / \mathrm{kg}$ in September. The average $\mathrm{Zn}$ concentration in 2012 was similar to those observed from 2009-2011, but remains below the highs observed in 2006-2008.

Silver extracted from sediments averaged $0.30 \mathrm{mg} / \mathrm{kg}$ in 2012 , higher than the record's lowest annual averages in 2008-2009 (0.20 mg) but still lower than the average for the 1994-2012 record. Silver concentrations have displayed a weak seasonal pattern over the record (fig. 8C); 2012 data do not display a discernable seasonal pattern (fig. 8, table 1). Maxima were observed in February and October $(0.37 \mathrm{mg} / \mathrm{kg}$ and $0.38 \mathrm{mg} / \mathrm{kg}$, respectively), and minima occurred in June and December $(0.21 \mathrm{mg} / \mathrm{kg}$ and $0.24 \mathrm{mg} / \mathrm{kg}$, respectively).

Mercury concentrations throughout all of 2012 were within the range usually observed in San Francisco Bay $(0.2-0.4 \mathrm{mg} / \mathrm{kg})$. The 2012 annual average of $0.22 \mathrm{mg} / \mathrm{kg}$ is the lowest of the record (1994-2012). Concentrations of $\mathrm{Hg}$ in sediment deviated slightly from the typical seasonal pattern. The highest concentration $(0.27 \mathrm{mg} / \mathrm{kg})$ occurred in both January and April, earlier than the late May maxima shown in many of the elements in 2012. Additionally, the lowest concentration of $\mathrm{Hg}$ was observed in December $(0.17 \mathrm{mg} / \mathrm{kg})$, which is later than in most years (fig. 9,1$)$.

Selenium concentrations decreased substantially in 2012 (annual average $0.30 \mathrm{mg} / \mathrm{kg}$ ) (fig. 9, table 1) from 2011 values, which were the second highest of the record at $0.60 \mathrm{mg} / \mathrm{kg}$. Annual average Se in 2012 was the third lowest concentration observed throughout the record (1994-2012). The minimum Se concentration occurred in September $(0.20 \mathrm{mg} / \mathrm{kg})$, typical of the seasonal pattern; maximum Se occurred in December $(0.41 \mathrm{mg} / \mathrm{kg})$, which is atypical of the record. This could be related to the massive rainstorms throughout the region in December 2012. Sedimentary Se has not exhibited a sustained temporal trend. Concentrations have varied annually during the record and since 2004 have alternated from relatively high concentrations $(2004,2006,2008$, and 2011) to relatively low concentrations $(2005,2007,2009-2010$, and 2012).

\section{Clam Tissue}

Metal concentrations in the soft tissues of Macoma petalum reflect a combination of metal exposures from water and food and the diluting and concentrating effects of gaining and losing tissue mass. Exposures to $\mathrm{Cu}$ and $\mathrm{Ag}$ at Palo Alto are of special interest because of the high tissue concentrations observed at this site in the past (figs. 10 and 11, appendix 9). During 1977-1987, the ranges in annual concentrations of $\mathrm{Cu}$ and $\mathrm{Ag}$ were $95-287 \mathrm{mg} / \mathrm{kg}$ and 45-106 mg/kg, respectively. Since 1987, concentrations have been considerably lower, $24-71 \mathrm{mg} / \mathrm{kg}$ for $\mathrm{Cu}$ and $1.8-20 \mathrm{mg} / \mathrm{kg}$ for Ag. Concentrations were particularly low and stable from 1997 through 2005, followed by a 2-year period of elevated concentrations in 2006-2007. Annual mean concentrations of $\mathrm{Cu}$ and Ag for 2012 were $32.6 \pm 3.8 \mathrm{mg} / \mathrm{kg}$ and $2.62 \pm 0.48 \mathrm{mg} / \mathrm{kg}$, respectively; these are within the range of concentrations observed since 1997. Concentrations of $\mathrm{Ag}$ and $\mathrm{Cu}$ in 2102 were slightly higher than the lowest values of the record, observed during 2008-2011.

Intraannual variations in $\mathrm{Ag}$ and $\mathrm{Cu}$ concentrations in clam soft tissues display a consistent seasonal signal characterized by fall/winter maxima and spring/summer minima. The amplitude of this seasonal cycle varies from year to year. For example, the winter maxima and the magnitude of seasonal 
Ag and $\mathrm{Cu}$ concentrations during 1994-1997 and in 2007 were relatively large and bracketed years of less variability (figs. 12 and 13). These trends most likely reflect the interaction of the changing exposure regime of the site (the long-term decline in metal concentrations) with the annual growth cycle of M. petalum (Cain and Luoma, 1990). In 2012, Ag and Cu concentrations were highest in January $(4.62 \mathrm{mg} / \mathrm{kg}$ and $44.4 \mathrm{mg} / \mathrm{kg}$, respectively). Concentrations decreased over the winter and reached their annual minima of $0.838 \mathrm{mg} / \mathrm{kg} \mathrm{Ag}$ and $15.5 \mathrm{mg} / \mathrm{kg} \mathrm{Cu}$ in May (table 2). Both $\mathrm{Cu}$ and Ag concentrations were low in June and steadily increased through the rest of the year, following a typical seasonal pattern.

As with $\mathrm{Cu}$ and $\mathrm{Ag}$, tissue concentrations of $\mathrm{Cr}$ (fig. 14, table 2), Ni (fig. 15, table 2), and Zn (fig. 16, table 2) also exhibited seasonal cycles. The seasonal cycles of $\mathrm{Cr}$ and $\mathrm{Ni}$ were very similar in terms of their timing and magnitude throughout the period of record (1994-2012). Maximum concentrations occurred in the winters of 1996-1997 and 2006-2007, whereas 2000-2002 was a period of relatively low winter-maximum concentrations. However, neither element exhibited a clear temporal trend (either downward or upward) in concentration. $\mathrm{Cr}$ and $\mathrm{Ni}$ concentrations for 2012 were slightly lower than 2011; the annual average concentration of $\mathrm{Ni}$ was the lowest of the record at $3.84 \mathrm{mg} / \mathrm{kg}$. Maximum concentrations of $\mathrm{Cr}$ and Ni occurred in January $(6.57 \mathrm{mg} / \mathrm{kg}$ and $5.87 \mathrm{mg} / \mathrm{kg}$, respectively), and minimum values occurred in May $(1.22 \mathrm{mg} / \mathrm{kg}$ and $2.64 \mathrm{mg} / \mathrm{kg}$, respectively).

In addition to the typical seasonal pattern, Zn concentrations exhibited a slight long-term decline of seasonal maxima through 2005. During 1994-1997, Zn concentrations were notably higher throughout the year than in subsequent years. In 2006, the seasonal cycle was weakly expressed, and concentrations increased notably to values comparable to those observed in the mid to late 1990s.

Seasonal patterns were evident in 2007-2009, weakly expressed in 2010-2011, and returned to a typical seasonal pattern in 2012. Concentrations of Zn over the past 5 years (2008-2012) were similar to those observed during 2000-2005. In 2012, the maximum Zn concentration occurred in January (377 mg/kg) and the minimum concentration in June (204 mg/kg). Wellise and others (1999) observed that seasonal and interannual patterns of $\mathrm{Cr}, \mathrm{Ni}$, and $\mathrm{Zn}$ in $\mathrm{M}$. petalum at Palo Alto were generally similar to those observed near the San Jose/Santa Clara Water Pollution Control Plant, indicating that regional-scale processes may be more important than treatment plant inputs in controlling the bioavailability of these elements.

Average $\mathrm{Hg}$ concentration in M. petalum for 2012 was the second lowest of the record at 0.28 $\mathrm{mg} / \mathrm{kg}$ (fig. 17, table 2). Seasonal variation for 2012 was nearly typical of the record, with a minimum of $0.18 \mathrm{mg} / \mathrm{kg}$ in June and early winter maxima in November and December $(0.30 \mathrm{mg} / \mathrm{kg}$ and $0.31 \mathrm{mg} / \mathrm{kg}$, respectively). A long-term trend in $\mathrm{Hg}$ concentration is not evident (fig. 17A).

Selenium concentrations in M. petalum in 2012 displayed the typical seasonal pattern of higher concentrations in the winter and lower concentrations in spring/summer. Selenium was highest in January ( $4.33 \mathrm{mg} / \mathrm{kg}$ ), then declined to the annual minimum in June (2.97 mg/kg) (fig. 18, table 2). Average Se concentrations had shown an increasing trend from 2007 to 2010, but average Se concentrations in 2011-2012 were the lowest since 2002-2003, reversing the trend. Long-term trends in the data are not evident.

Data on the condition index (CI) for M. petalum at Palo Alto extend back to 1988 (fig. 19, table 2). As previously discussed, the data fluctuate seasonally in relation to growth and reproductive cycles, and annual cycles differ in magnitude. Maximum CI (188 mg) and average CI (132 mg) in 2012 were typical for the record and consistent with values observed since 2007.

\section{Reproduction of Macoma petalum}

Earlier studies (Hornberger and others, 2000b; Shouse and others, 2004) found that low reproductive activity in $M$. petalum in the late 1970 s coincided with highly elevated concentrations of 
$\mathrm{Ag}$ (and perhaps $\mathrm{Cu}$ ) in the soft tissues. During this period, Macoma exhibited extended periods (as long as 2 months) of reproductive inactivity. Following the decline in tissue concentrations of $\mathrm{Ag}$ and $\mathrm{Cu}$ in the 1980s, reproductive activity of M. petalum improved (fig. 20). Furthermore, the low reproductive activity observed during the late 1970s has not been observed during the entire period of reduced metal exposures. The temporal coincidence of these events indicates that reproductive activity was related to the concentration of metals in the animal. This finding has implications for the reproductive success of the population.

The time series of reproductive activity (figs. 20 and 21) shows that $M$. petalum continues to be highly reproductive relative to the 1970 s, with a high percentage of the animals being reproductively active at any one time during the normal seasonal cycle of reproduction. That cycle begins in fall, with spawning occurring the following spring (see table 3 for detailed reproduction data for 2012). A closer look at the past 6 years of data demonstrates this seasonality of reproduction-in contrast to earlier periods, animals do not stay reproductively inactive for longer than a month or two.

\section{Benthic Community}

Estimates of species diversity and total animal abundance are simple metrics that are used in assessing environmental stress on biological communities. Species diversity at the Palo Alto site, as estimated by a time series of number of species, continues to show an upward trend (with one exception) since the last very wet year in 1998 (fig. 22). Total animal abundance has varied significantly during the sampling period (fig. 23). The difficulty with these types of metrics is that they do not consider the possibility that one species can take the place of another or that high abundance may be based on one species. Depending on the characteristics of a species new to the community or newly dominant in the community, the community structure and function may change as a result of this change in species composition or dominance. The details of changes in species composition are important because they may reflect the relative ability of species to accommodate environmental stress and redistribute site resources. In general, the species composition at the study site has changed little since 1998, although there have been seasonal eruptions of several species in some years.

Three common bivalves (Macoma petalum, Mya arenaria, and Gemma gemma) have not shown any consistent trend over the 39-year period from 1974 to 2012 (figs. 24, 25, and 26). Significant seasonal and interannual variability has been displayed in species abundances for all species found at the Palo Alto site. The three common bivalves illustrate this variability well; Gemma gemma has been particularly volatile since 2005. Gemma gemma abundance dropped to near zero in late fall 2007 and has not regained its previous high density, although the abundance has now rebounded to levels seen in the early 2000s.

Six species have shown trends in their abundance since the 1970s, and these trends continued through 2012. The first of these species, Ampelisca abdita, is a small crustacean that lives above the surface of the mudflat in a tube built from selected sediment particles. A. abdita showed a general decline in abundance (fig. 27) after 1998. That pattern mostly continues through today. The second species to show a significant trend is the small polychaete worm Streblospio benedicti, which also builds a tube above the surface of the mudflat. As with A. abdita, S. benedicti abundance has declined through the study years and, over the past 4 years, the species has settled into a seasonal pattern of increasing fall abundance followed by a winter decline (fig. 28). The abundance of the small burrowing crustacean Grandiderella japonica, a deposit feeder, became more seasonally consistent after 2000 (fig. 29), although the population abundance was particularly low in 2011. This species has shown a consistent peak in abundance in the fall since 1999, with the exception of 2011. Neanthes succinea, a burrowing polychaete that feeds on surface deposits and scavenges for detrital food, showed large seasonal fluctuations in abundance through the 1980s. N. succinea abundance became more stable in the 
late 1990s and remained so until 2005, when the abundance decreased (fig. 30). N. succinea abundance declined further in 2011. In 2012, N. succinea abundance rebounded to pre-2011 numbers. Two species showed an increase in abundance within the time series. The first was the polychaete worm Heteromastus filiformis (fig. 31), a subsurface deposit-feeding, burrowing species that lives deep in the sediment (usually 5-20 cm below the surface of the mudflat). Abundance increased sharply in 1985 and then partially receded in the late 1980s. Abundance remained higher than in the late 1970s until 2008, when there was a large decline in $\mathrm{H}$. filiformis abundance (fig. 22). H. filiformis abundance increased slightly in 2011 and 2012; 1980s abundance data indicate that this is a species that increases slowly, possibly because of their egg-laying mode of recruitment. The second species showing an increase was Nippoleucon hinumensis, a small, burrowing, surface deposit-feeding crustacean, which appeared in the dataset in 1988 (fig. 32) following its introduction into the bay in 1986 (Cohen and Carlton, 1995).

Another nonindigenous species, Potamocorbula amurensis, a filter-feeding bivalve that first appeared in the benthic community in significant numbers in April 2005 and persisted into 2006 with peaks in abundance occurring in spring and fall, has continued to be present in 2012. A complete list of the benthic species found at the Palo Alto site in the year 2012 is shown in appendix 10. The benthic species name changes (as of 2012) for appendix 10 are shown in appendix 11.

A sudden drop in animal abundance was observed in February 2008. Very few animals of any species were found at the site, and the mudflat community was evidently stressed by some event between the January and February sampling. Possible causes of the stress include sedimentation or freshwater inundation. There was a large storm on January 25, 2008, with rainfall rates exceeding 0.5 $\mathrm{cm} / \mathrm{hr}$ for more than half the day, including during the low-tide period. No obvious changes in the sediment surface were observed, but sediment changes can occur and be incorporated quickly in this tidal environment. Other possible causes of benthic community death or exodus include a toxic event or anoxia. It is unlikely that either of these occurred, because $M$. petalum were present in the deep sediment in February 2008, and animals were found again at the site in March 2008. This would not happen with toxicity or anoxia. The timeline for recovery from anoxia can be estimated on the basis of observations following an anoxic event at this site in 1975. Macroalgae were deposited on the mudflat surface and began to decay, and the resulting bacterial consumption of oxygen led to anoxia. The benthic community took many months to recover from this anoxic event. Animals that returned after the disturbance in 2008 include those species with pelagic larvae and mobile adults, as would be expected. Nonmobile brooders returned to the site in 2009, concurrent with an increase in abundance of the brooding clam G. gemma and the brooding polychaete Streblospio benedicti. This trend continued into 2012, when brooders and oviparous species were more than half of the top 10 most abundant species (fig. 39).

As stated earlier, multivariate analyses of population data of the dominant species with environmental parameters did not reveal any relations, except with the concentration of $\mathrm{Ag}$ and $\mathrm{Cu}$ in the sediment and in the tissue of $M$. petalum (using data reported by David and others, 2002). Therefore, this update will consider only those metals. Metal concentration and abundance of species with the most susceptible mode of feeding and reproduction will be compared over the period of the study. One such susceptible species, the worm $\mathrm{H}$. filiformis, increased in abundance with the decrease in $\mathrm{Ag}$ and $\mathrm{Cu}$ until 2008 (fig. 31). This was of interest because $H$. filiformis has continual tissue contact with the sediment at the exterior of its body, as well as within its body, as a result of its lifestyle of burrowing through the sediment and consuming a diet of mud and organic particles. In addition, this is one of the few species in the present community that reproduces exclusively by laying its eggs in the sediment. The larvae hatch after 2 or 3 days and spend a very short period (2-3 days) as plankton before settling back to the mud as juvenile worms (Rasmussen, 1956). The short planktonic period limits the species' speed of 
expansion into new areas. We hypothesize that once a few individuals successfully arrived at the study site, $H$. filiformis increased in abundance because either the adult worms or the eggs now found the environment agreeable. This species is not likely to move into an area quickly after an environmental stressor because of its mode of reproduction and short planktonic larval period. A large spike in $H$. filiformis abundance was observed in January 2008 because of the settling of larvae, but these larvae did not survive the subsequent event that occurred before the February sampling. So far, the species has not returned in high numbers to the study site. The dynamics of recovery for this species will continue to be monitored closely.

Two species that have shown the opposite trend of $H$. filiformis, the crustacean A. abdita (fig. 27 ) and the worm $S$. benedicti (fig. 28), have declined in abundance coincident with the decline in metals. These species have very similar life-history characteristics that make them less susceptible to high $\mathrm{Ag}$ and $\mathrm{Cu}$ concentrations in sediment. Both species live on the surface of the sediment in tubes that are built from sediment particles. They feed on particles in the water column or on particles that have settled to the sediment surface, brood their young, and produce young that are capable of either swimming or settling upon hatching. These opportunistic characteristics make these species ideal for invading a disturbed or stressed environment; thus, they are capable of rapid increase in population size and distribution. It is not surprising that both species immediately responded to the near-empty community in February 2008 and have subsequently declined (figs. 27 and 28). This abundance pattern is consistent with what is expected of an opportunistic species.

Other species share the characteristics highlighted in our discussion of $H$. filiformis, $S$. benedicti, and A. abdita; the species with similar characteristics have been combined into plots that examine the percent of abundance represented by each feeding and reproductive mode (figs. 33-36). Because the natural spatial variability (that is, the large standard deviations around the monthly means) and seasonal variability of invertebrate abundance can be quite large, the average percentages for the month of August of each characteristic reproductive and feeding mode are shown in figures 33-36. To interpret these plots, the life-history characteristics must first be examined to determine if there is some mechanism by which this organism could be responding to a decrease in $\mathrm{Ag}$ or $\mathrm{Cu}$ in the environment. It is likely that $\mathrm{Ag}$, but probably not $\mathrm{Cu}$, adversely affected reproduction of all animals, but it was most obvious in species with juveniles that were not transported from outside the area as pelagic larvae. Therefore, the species having oviparous and mixed (species capable of both oviparity and brooding) reproductive modes (Ahn and others, 1995; Hornberger and others, 2000b) are worth examining in the early years of the study. The gradual increase in abundance of this group through 1983 occurred with the gradual reduction of metals in the environment during that time. In the present environment of much lower metal concentrations, these species respond to a variety of stresses, and their percentage of brooding and oviparous individuals in the community reflects those stresses (figs. 33 and 34). Although the percentage is volatile, it never stays as low as it was in the early 1970s. The authors interpret this as being a reflection of the general health of the benthic environment. In a similar manner, we can examine the feeding modes of the majority of the individuals (figs. 35 and 36). High concentrations of either $\mathrm{Cu}$ or Ag are unlikely to be healthy for species that ingest the sediment in order to consume the interstitial and attached carbon; thus, it is reasonable to expect species that consume particles from the water column to be more protected from the contaminants in the sediment. Filter-feeding species are usually the dominant group throughout the dataset, and the subsurface deposit feeders are the group that shows the largest increase in dominance after the 1970s. This is consistent with the conceptual model posed here.

The change in function of the benthic community over time can be examined by ranking the top 10 species by abundance and plotting the $\log (n+1)$ of mean abundance against the rank of each 
species. The plot for 2012 (fig. 37) is indicative of a healthy benthic community, with species dominance, as revealed by abundance, not showing large differences among the top 10 species. A comparison of plots for three hydrologically dry years during this study (fig. 37; 1977, 1989, and 2002) shows that the shape of the curve has changed greatly with time. The community was heavily dominated by three species in 1977 and 1989, whereas 1-2 species were dominant in 2002 and 2012. The 1977 community plot is the most extreme and reflects a bimodal species distribution, with three species dominating the community and the remainder having similar but relatively low abundances. The 1977 community was dominated by opportunistic species. In contrast, the 2012 community plot is dissimilar because the opportunists are present but display less dominance in the community (the most opportunistic species rank 3 and 4 in 2012).

It is informative to examine the rank-abundance plots within the context of the life-history characteristics of each species to determine if shifts in plot shape coincide with a shift in community structure and function that might be indicative of a healthier environment. Two critical life-history characteristics are shown: feeding mode in figure 38 and reproductive mode in figure 39. The 1977 community was dominated by filter feeding species (species that consume particles in the water column), species that have the option of either filter feeding or feeding on the sediment surface (mixed feeders), and two species that feed on food particles on the sediment surface. In 1989, the species composition had shifted such that filter feeding species, subsurface-deposit and surface-deposit feeding species (those that ingest sediment and strip the food off of the sediment in their gut) dominated the community. In 2002, a shift was observed towards species that could either filter feed or deposit feed (mixed feeders) and those species that feed on subsurface sediment. The most recent data (2012) show the community to be composed of an almost even mix of surface-deposit feeding species, filter feeding species, and mixed feeding species. Over the period of this study, a shift has occurred from a community dominated by species that feed either in the water column or on recently settled food particles on the sediment surface to a mixed community of species that feed directly on the subsurface sediment, those capable of feeding in the water column, and those feeding on the sediment surface. The species that returned following the defaunation event in January/February 2008 have maintained this pattern. Thus, it is unlikely that any sediment-borne pollutant caused the collapse of the community in early 2008.

An examination of these rank-abundance plots using reproductive mode as the descriptor for each point is equally informative (fig. 39). The dominant species in 1977 were species that brood their young and release fully functional juveniles into the environment. In 1989, there were still several brooders, but there were also two species that lay their eggs in the sediment. Although brooding species remain in the 10 most abundant species, species that spawn their gametes into the water column and those that lay eggs in the sediment (oviparous) have equal presence. It is possible that some of the metal contaminants found in the sediment in the 1970s at this location limited the success of species that consumed the sediment for food, laid eggs in the sediment, or depended on water-borne larvae to repopulate the community. The reproductive mode of most species present in 2012 is brooding, with some spawners.

\section{Summary}

\section{Long-Term Observations}

Since 1974, USGS personnel have monitored and conducted basic research on the benthic sediments and biological community in the vicinity of the discharge of the Palo Alto Regional Water Quality Control Plant (PARWQCP). The time series presented here update previous findings (for 
example, Hornberger and others, 2000a; Luoma and others, 1991, 1995a, 1996; Moon and others, 2005; Shouse and others, 2003, 2004; Thompson and others, 2002; Cain and others, 2006; Dyke and others, 2010, 2011) with additional data from January 2011 through December 2011 to create a record spanning 38 years. This long-term dataset includes sediment chemistry and tissue concentrations of metals (19772011 for $\mathrm{Cu}$ and Ag, 1994-2011 for other metals), condition index (1988-2011), and reproductive activity in $M$. petalum and population dynamics of benthic invertebrate species (1974-2011). The time series encompasses the period when exceptionally high concentrations of $\mathrm{Cu}$ and $\mathrm{Ag}$ were found in $M$. petalum (1970s) and the subsequent period when those concentrations declined. The sustained record of biogeochemical data at this site provides a rare opportunity to examine the biological response to metal contamination within this ecosystem.

Studies during the 1970s showed that sediments and M. petalum at the Palo Alto site contained highly elevated levels of metals, especially $\mathrm{Ag}$ and $\mathrm{Cu}$, as a result of metal-containing effluent being discharged from the Palo Alto Regional Water Quality Control Plant (PARWQCP) to South San Francisco Bay. In the early 1980s, the point-source metal loading from the nearby PARWQCP was significantly reduced as a result of advanced treatment of influent and source mitigation. Coincident with declines in metal loadings, concentrations of metals in the sediment and in the clam M. petalum (serving as a biomonitor of metal exposures) also declined, as previously described by Hornberger and others (2000b). Interannual trends in clams and sediments were highly correlated with $\mathrm{Cu}$ loadings from PARWQCP (concurrent loading data for Ag were not available). Metal levels in sediments and clams responded relatively quickly to changes in metal loading; the reduction in metal loadings by the PARWQCP resulted in a reduction in metal concentrations in both the sediment and $M$. petalum within a year (Hornberger and others, 2000b).

Biological responses to metal inputs to South San Francisco Bay were assessed at different levels of organization. These responses are interpreted within the appropriate temporal context. Because metal exposures were already high when the study began, interpretations are based on observed changes in biological attributes as metal inputs declined. In general, discernable responses at the organism level (that is, reproductive activity, a manifestation of a cellular or physiological change) to metal exposure may occur within a relatively short time, whereas population and community level responses take longer to develop. Stable changes in the benthic community may take a relatively long period of time to be expressed because of the normally high degree of intra-annual variability of benthic community dynamics, which reflects the cumulative response to natural and anthropogenic disturbances. It is therefore critical that sampling frequency and duration be conducted at temporal scales appropriate to characterize the different biological responses.

During the first 10 years of this study, when the metal concentrations were high and declining, the benthic community was largely composed of nonindigenous, opportunistic species that dominated because of their ability to survive the many physical disturbances on the mudflat (Nichols and Thompson, 1985a, 1985b). These disturbances included sediment erosion and deposition and aerial exposure at extreme low tides, as well as less well defined stresses. The possible effects of metal exposure as a disturbance factor were not considered in the analyses by Nichols and Thompson because the decline in metal concentrations in $M$. petalum and sediment had just begun.

However, data collected throughout the period of declining metal exposure have revealed biological responses to this metal decline. Reproductive activity improved within a year or two of reduced metal exposure, and responses at the population and community levels were observed afterward. Identification of these responses was possible because the frequency of sampling allowed long-term trends related to metal contamination to be identified within the context of repeating seasonal cycles and unrelated intra-annual variation. 
The ecology of the Palo Alto mudflats is part of the larger South San Francisco Bay, which has been undergoing some changes in recent years. During 1999-2005, USGS scientists noticed an increase in phytoplankton biomass in the southern bay. Sampling in the deeper water of the southern bay showed that the bivalves were mostly absent from the system during this increase in primary production. Cloern and others (2007) indicate that the cause of the decline in bivalves was an increase in fish predators resulting from increased offshore upwelling activity. The higher reproductive success of demersal fish, crabs, and shrimp during this period resulted in a higher number of juveniles moving into the South San Francisco Bay to grow. Since 2005, scientists have seen the large bivalve populations fluctuate more than in previous years, and these fluctuations have been reflected in changes in phytoplankton biomass in the system (primarily through an increase in phytoplankton biomass in late summer and fall). The value of these findings in greater South Bay to this study is twofold. First, it reinforces the importance of the benthic community in structuring the ecosystem function. Second, it shows that the high intertidal community at the Palo Alto site has not been demonstrably affected by these greater South San Francisco Bay influences during these years. This finding solidifies the authors' confidence that the changes observed in the benthic community are in large part due to local factors.

\section{Observations}

Throughout 2012, $\mathrm{Cu}$ and $\mathrm{Ag}$ concentrations in sediments and soft tissues of the clam, $M$. petalum, remained representative of the concentrations observed since 1991, following the significant reductions in concentrations during the 1980s that coincided with reductions in the discharge of these elements from PARWQCP. Since 1991, annual mean $\mathrm{Cu}$ and $\mathrm{Ag}$ concentrations have fluctuated modestly and without any extended trends. This is also true for other elements. For example, Se concentrations in surface sediment declined in 2009-2010 from the record high concentrations observed in 2008, but increased in 2011 to levels similar to 2006; Se in 2012 decreased to about half the annual average observed in 2011. Sedimentary Se concentrations have been variable from year to year and showed no sustained temporal trend. In another example, annual average concentrations of $\mathrm{Cu}$ and $\mathrm{Ag}$ in $M$. petalum were relatively low from 1997 to 2005, increased notably in 2006-2007, and returned to 1997-2005 levels during 2008-2011. For Ag and Cu, annual averages were slightly higher in 2012 than in the previous 4 years but still lower than 2006-2007 values. The most recent results (2012) show that $\mathrm{Ag}$ and $\mathrm{Cu}$ in $\mathrm{M}$. petalum are only 3 percent and 14 percent, respectively, of the maximum values observed during 1978-1980. Concentrations of Ag and $\mathrm{Cu}$ in sediments in 2012 were 19 percent and 45 percent, respectively, of the record high concentrations observed in 1979. Interannual variation in $\mathrm{Cu}$ and $\mathrm{Ag}$ in M. petalum from 1991 to 2006 did not correlate with discharge of $\mathrm{Cu}$ and $\mathrm{Ag}$ from PARWQCP (Lorenzi and others, 2007), indicating that, as with other elements of regulatory interest, including $\mathrm{Cr}, \mathrm{Ni}$, and $\mathrm{Zn}$, regional-scale factors now largely influence sedimentary and bioavailable concentrations (see, for example, Luoma and others, 1998). Abiotic factors that affect the seasonal and year-to-year patterns in sedimentary and tissue concentrations may include precipitation, nonpointsource runoff, cycling of legacy contamination, accelerated erosion of salt marsh banks in recent years, and periods of accretion and erosion of sediment on the mudflat.

The long-term dataset demonstrates various adverse effects of contaminants on benthic organisms. Decreasing particulate concentrations of trace metals in the local environment have benefited resident populations of invertebrates, as evidenced by increased reproductive activity in $M$. petalum that has been sustained through 2012 . In early 2008, the benthic community declined, with few animals present in February. This decline was likely the result of a natural stressor, such as a sedimentation or freshwater event, and the composition of the benthic community supports that supposition. Mobile animals, such as M. petalum, that were capable of burrowing down to avoid the stressor probably did so, but many other species either relocated or were killed. This natural disturbance 
has given scientists the opportunity to observe mudflat community recovery from a natural stressor and to compare this recovery to that observed during the long-term decline in metals. Shifts in species abundance at Palo Alto have been interpreted to be a response to decreasing sediment contaminants. These community changes have included a shift from species that live on the surface, filter food out of the water column or consume particles on the sediment surface, and brood their young to a community dominated by species that live on and below the surface, consume the sediment directly to harvest food particles, and spawn and lay eggs in the sediment. The 2008-2012 data reveal a community that had a short-term physical stressor but not one that was subject to unhealthy sediment. In 2012, the data continue to show signs of recovery and further examples of the community dynamics in terms of the species present as well as the stability of the ecosystem in terms of functional group consistency. This "natural experiment" has given USGS scientists a great opportunity to test various hypotheses on the benthic community response to different stressors. Future data will further refine the understanding of the response of this benthic community to natural and anthropogenic stressors.

\section{Value of Long-Term Monitoring}

This study highlights the importance of long-term ecosystem monitoring. The decadal time series produced during the course of sustained efforts at this site have made it possible to describe trends, identify previously undocumented phenomena, and pose hypotheses that have guided past detailed explanatory studies and can guide future studies. Monitoring studies cannot always unambiguously determine the causes of trends in metal concentrations or benthic community structure. The strength and uniqueness of this study is the integrated analysis of metal exposure and biological response at intra- and interannual time scales over multiple decades. Changes and trends in community structure that may be related to anthropogenic stressors, as was seen in this study, can be established only with a concerted and committed effort of sufficient duration and frequency of sampling. Such rare field designs allow biological responses to natural stressors to be characterized and separated from those to stressors introduced by humans. Through interpreting time-series data, it has been possible to separate anthropogenic effects from natural annual and interannual variability. The data from the recent record (that is, within the past decade) increasingly appear to be indicative of an integrated regional ecological baseline with indicators of metal contamination and greater physiological well-being of aquatic life and benthic community structure. Changes are occurring in the South San Francisco Bay watershed. For example, implementation is beginning in the South Bay Salt Ponds Restoration Program; with unknown implications (positive or negative) for all of South San Francisco Bay. Nanomaterials, many of which include metal-based products in forms for which environmental researchers have little or no experience, are being used in an increasing number of common consumer products. The long-term, detailed, integrated ecological baseline that has been established at this sampling site will be uniquely valuable in assessing the response of the environment as human activities in the watershed continue to change.

\section{Selected References}

Ahn, I.Y., Kang, Y.C, and Choi, J.W., 1995, The influence of industrial effluents on the intertidal benthic communities in Panweol, Kyeonggi Bay (Yellow Sea) on the west coast of Korea: Marine Pollution Bulletin, v. 30, p. 200-206.

Alpine, A.E., and Cloern, J.E., 1992, Trophic interactions and direct physical effects control phytoplankton biomass and production in an estuary: Limnology and Oceanography, v. 37, p. 946955.

Begon, M., Harper, J.L., and Townsend, C.R., 1986, Ecology; individuals, populations and communities: Sunderland, Massachusetts, Sinauer Associates Inc., 876 p. 
Cain, D.J., and Luoma, S.N., 1990, Influence of seasonal growth, age and environmental exposure on $\mathrm{Cu}$ and $\mathrm{Ag}$ in a bivalve indicator, Macoma balthica in San Francisco Bay: Marine Ecology Progress Series 60, p. 45-55.

Cain, D.J., Parchaso, F., Thompson, J.K., Luoma, S.N., Lorenzi, A.H., Moon, E., Shouse, M.K., Hornberger, M.I., and Dyke, J.L., 2006, Near-field receiving water monitoring of trace metals and a benthic community near the Palo Alto Regional Water Quality Control Plant in South San Francisco Bay, California; 2005: U.S. Geological Survey Open-File Report 2006-1152, 128 p.

Cain, D.J., Thompson, J.K., Dyke, J.L., Parchaso, F., Luoma, S.N., and Hornberger, M.I., 2009, Nearfield receiving water monitoring of trace metals and a benthic community near the Palo Alto Regional Water Quality Control Plant in South San Francisco Bay, California; 2008: U.S. Geological Survey Open-File Report 2009-1193, 120p.

Childress, C.J.O., Foreman, W.T., Connor, B.F., and Maloney, T.J., 1999, New reporting procedures based on long-term method detection levels and some considerations for interpretations of waterquality data: U.S. Geological Survey Open-File Report 99-193, 19 p.

Cloern, J.E., Jassby, A.D., Thompson, J.K, and Hieb, K., 2007, A cold phase of the east Pacific triggers new phytoplankton blooms in San Francisco Bay: Proceedings National Academy of Science, v. 104, no. 47, p. 18561-18565.

Cohen, A.N., and Carlton, J.T., 1995, Biological study, nonindigenous aquatic species in a United States estuary; a case study of the biological invasions of the San Francisco Bay and Delta: Washington, D. C., U.S. Fish and Wildlife Service.

David, C.P.C., Luoma, S.N, Brown, C., Cain, D.J, Hornberger, M., and Lavigne, I.R., 2002, Near-field receiving water monitoring of trace metals in clams (Macoma balthica) and sediments near the Palo Alto Water Quality Control Plant in South San Francisco Bay, California; 1999-2001: U. S. Geological Survey Open-File Report 02-453, 105 p.

Dyke, J.L., Parchaso, F., Thompson, J.K., Cain, D.J., Luoma, S.N., and Hornberger, M.I., 2010, Nearfield receiving water monitoring of trace metals and a benthic community near the Palo Alto Regional Water Quality Control Plant in South San Francisco Bay, California: 2009, U.S. Geological Survey Open-File Report 2010-1188, 142 p.

Dyke, J.L., Parchaso, F., Thompson, J.K., Cain, D.J., Luoma, S.N., and Hornberger, M.I., 2011, Nearfield receiving water monitoring of trace metals and a benthic community near the Palo Alto Regional Water Quality Control Plant in South San Francisco Bay, California: 2010, U.S. Geological Survey Open-File Report 2011-1163, 114 p.

Dyke, J.L., Parchaso, F., Thompson, J.K., Cain, D.J., Luoma, S.N., and Hornberger, M.I., 2012, Nearfield receiving water monitoring of trace metals and a benthic community near the Palo Alto Regional Water Quality Control Plant in South San Francisco Bay, California: 2011, U.S. Geological Survey Open-File Report 2012-1165, 108 p.

Elrick, K.A., and Horowitz, A.J., 1985, Analysis of rocks and sediments for arsenic, antimony, and selenium, by wet digestion and hydride generation atomic absorption: U.S. Geological Survey OpenFile Report 85-497, 14 p.

Glaser, J.A., Foerst, D.L., Mckee, G.D., Quave, S.A., and Budde, W.L., 1981, Trace analyses for wastewaters: Environmental Science and Technology, v. 15, no. 12, p. 1426-1435.

Harris, D., Horwáth, W.R., and van Kessel, C., 2001, Acid fumigation of soils to remove carbonates prior to total organic carbon or CARBON-13 isotopic analysis: Soil Science Society of America Journal, v. 65, p. 1853-1856.

Hornberger, M.I., Luoma, S.N., Van Geen, A., Fuller, C.C., and Anima, R., 1999, Historical trends of metals in the sediments of San Francisco Bay, California: Marine Chemistry, v. 64, p. 39-55. 
Hornberger, M.I., Luoma, S.N., Cain, D., Parchaso, F., Brown, C., Bouse, R., Wellise, C.J., and Thompson, J., 2000a, Bioaccumulation of metals by the bivalve Macoma balthica at a site in South San Francisco Bay between 1977 and 1997; long-term trends and associated biological effects with changing pollutant loadings: U. S. Geological Survey Open-File Report 99-55, 42 p.

Hornberger, M., Luoma, S., Cain, D., Parchaso, F., Brown, C., Bouse, R., Wellise, C., and Thompson, J., 2000b, Linkage of bioaccumulation and biological effects to changes in pollutant loads in South San Francisco Bay: Environmental Science and Technology, v. 34, p. 2401-2409.

Kennish, J.K., 1998, Pollution impacts on marine biotic communities: New York, CRC Press, 310 p. Liber, K, 2011, Cold Digestion of Invertebrates for the Selenium Project. Method developed C.W. and E.F. 2007. Revised Mar 2011 MK: Water Quality Laboratory, Toxicology Center, University of Saskatchewan.

Long, E.R., MacDonald, D.D., Smith, S.L., and Calder, F.D., 1995, Incidence of adverse biological effects within ranges of chemical concentrations in marine and estuarine sediments: Environmental Management, v. 19, p. 81-97.

Lorenzi, A., Cain, D.J., Parchaso, F., Thompson, J.K., Luoma, S.N., Hornberger, M.I., Dyke, J.L., Cervantes, R., and Shouse, M.K., 2007, Near-field receiving water monitoring of trace metals and a benthic community near the Palo Alto Regional Water Quality Control Plant in South San Francisco Bay, California; 2006: U.S. Geological Survey Open-File Report 2007-1199, 121 p.

Lorenzi, A., Cain, D.J., Parchaso, F., Thompson, J.K., Luoma, S.N., Hornberger, M.I., and Dyke, J.L., 2008, Near-field receiving water monitoring of trace metals and a benthic community near the Palo Alto Regional Water Quality Control Plant in South San Francisco Bay, California; 2007: U.S. Geological Survey Open-File Report 2008-1180, 120 p.

Luoma, S.N., Cain, D.J., and Johansson, C., 1985, Temporal fluctuations of silver, copper and zinc in the bivalve Macoma balthica at five stations in South San Francisco Bay: Hydrobiologia, v. 129, p. $109-120$.

Luoma, S.N., Cain, D.J., Brown, C. and Axtmann, E.V., 1991, Trace metals in clams (Macoma balthica) and sediments at the Palo Alto mudflat in South San Francisco Bay; April, 1990-April, 1991: U. S. Geological Survey Open-File Report 91-460, 47 p.

Luoma, S.N., Cain, D.J., Brown, C., and Hornberger, M., 1992, Trace metals in clams (Macoma balthica) and sediments at the Palo Alto mudflat in South San Francisco Bay; May 1991-May 1992: U. S. Geological Survey Open-File Report 92-456, 51 p.

Luoma, S.N., Cain, D.J., Brown, C., and Hornberger, M., 1993, Trace metals in clams (Macoma balthica) and sediments at the Palo Alto mudflat in South San Francisco Bay; June 1992-June 1993: U. S. Geological Survey Open-File Report 93-500, 52 p.

Luoma, S.N., Cain, D.J., Brown, C., and Hornberger, M., 1995a, Near-field receiving water monitoring of trace metals in clams (Macoma balthica) and sediments near the Palo Alto and San Jose/Sunnyvale Water Quality Control Plants in South San Francisco Bay; June 1993-October 1994: U. S. Geological Survey Open-File Report 95-299, 83 p.

Luoma, S.N., Ho, Y.B, and. Bryan, G.W., 1995b, Fate, bioavailability and toxicity of silver in estuarine environments: Marine Pollution Bulletin, v. 31, p. 44-54.

Luoma, S.N., Cain, D.J., Brown, C., Hornberger, M., and Bouse, R. 1996, Near-field receiving water monitoring of trace metals in clams (Macoma balthica) and sediments near the Palo Alto and San Jose/Sunnyvale Water Quality Control Plants in South San Francisco Bay; December 1994-December 1995: U. S. Geological Survey Open-File Report 96-203, 90 p.

Luoma, S.N., Cain, D.J., Brown, C., Hornberger, M., and Bouse, R. 1997, Near-field receiving water monitoring of trace metals in clams (Macoma balthica) and sediments near the Palo Alto and San 
Jose/Sunnyvale Water Quality Control Plants in South San Francisco Bay; 1996: U. S. Geological Survey Open-File Report 97-585, 91 p.

Luoma, S.N., Wellise, C, Cain, D.J., Brown, C., Hornberger, M., and Bouse, R., 1998, Near-field receiving water monitoring of trace metals in clams (Macoma balthica) and sediments near the Palo Alto and San Jose/Sunnyvale Water Quality Control Plants in South San Francisco Bay; 1997: U. S. Geological Survey Open-File Report 98-563, 88 p.

Moon, E., David, C.P.C., Luoma, S.N, Cain, D. J, Hornberger, M., and Lavigne, I.R., 2003, Near field receiving water monitoring of trace metals in clams (Macoma balthica) and sediments near the Palo Alto Water Quality Control Plant in South San Francisco Bay, California; 2002: U.S. Geological Survey Open-File Report 03-339, 78 p.

Moon, E., Luoma, S.N, Cain, D.J., Hornberger, M., and David, C.P.C., 2004, Near field receiving water monitoring of trace metals in clams (Macoma balthica) and sediments near the Palo Alto Water Quality Control Plant in South San Francisco Bay, California; 2003: U.S. Geological Survey OpenFile Report 2004-1213, 84 p.

Moon, E., Shouse, M.K., Parchaso, F. Thompson, J.K., Luoma, S.N., Cain, D.J. and Hornberger, M.I., 2005, Near-field receiving water monitoring of trace metals and a benthic community near the Palo Alto Regional Water Quality Control Plant in South San Francisco Bay, California; 2004: U.S. Geological Survey Open-File Report 2005-1279, 118 p.

Morrisey, D.J., Underwood, A.J., and Howitt, L., 1996, Effects of copper on the faunas of marine softsediments; an experimental field study: Marine Biology, v. 125, p.199-213.

Nichols, F.N., and Thompson, J.K., 1985a, Persistence of an introduced mudflat community in South San Francisco Bay, California: Marine Ecology Progress Series, v. 24, p. 83-97.

Nichols, F.N., and Thompson, J.K., 1985b, Time scales of change in the San Francisco Bay benthos: Hydrobiologia, v. 129, p. 121-138.

Parchaso, F., 1993, Seasonal reproduction of Potamocorbula amurensis in San Francisco Bay, California: San Francisco, California, San Francisco State University, M.S. thesis.

Rasmussen, E., 1956, The reproduction and larval development of some polychaetes from the Isefjord, with some faunistic notes: Biologiske Meddelelser, published by det Kongelige Danske Videnskabernes Selskab, v. 23, no. 1, p. 1-84.

Rygg, B., 1985, Effect of sediment copper on benthic fauna: Marine Ecology Progress Series, v. 25, p. 83-89.

San Francisco Estuary Institute, 1997, RMP, regional monitoring program for trace substances; 1996: Richmond, California, San Francisco Estuary Institute, 349 p.

Shouse, M.K., 2002. The effects of decreasing trace metal concentrations on benthic community structure: San Francisco, California, San Francisco State University, M.S. thesis, 177 p.

Shouse, M.K., Parchaso, F., and Thompson, J.K. 2003, Near-field receiving water monitoring of benthic community near the Palo Alto Water Quality Control Plant in South San Francisco Bay; February 1974 through December 2003: U.S. Geological Survey Open-File Report 2003-224, 39 p.

Shouse, M.K., Parchaso, F., and Thompson, J.K., 2004, Near-field receiving water monitoring of benthic community near the Palo Alto Water Quality Control Plant in South San Francisco Bay; February 1974 through December 2003: U.S. Geological Survey Open-File Report 2004-1210, 39 p. Simon, T.P., 2002, Biological response signatures: Boca Raton, Florida, CRC Press, 608 p.

Thompson, J.K., and Parchaso, F., 2012, Benthic invertebrate community assessment as a phytoplankton consumer and fish and bird prey source before and after the start of the restoration: South Bay Salt Pond Restoration Project Cooperative Agreement \#2009-0211, 90 p. 
Thompson, J.K., Parchaso, F., and Shouse, M.K., 2002, Near-field receiving water monitoring of benthic community near the Palo Alto Water Quality Control Plant in South San Francisco Bay; February 1974 through December 2000: U.S. Geological Survey Open-File Report 02-394, 117 p.

Thomson, E.A., Luoma, S.N., Johansson, C.E., and Cain, D.J., 1984, Comparison of sediments and organisms in identifying sources of biologically available trace metal contamination: Water Research, v. 18 , p. $755-765$.

Thomson-Becker, E.A., and Luoma, S.N., 1985, Temporal fluctuations in grain size, organic materials and iron concentrations in intertidal surface sediment: Hydrobiologia, v. 129, p. 91-109.

Topping, B.R., and Kuwabara, J.S., 2003, Dissolved nickel and benthic flux in south San Francisco Bay; a potential for natural sources to dominate: Bulletin of Environmental Toxicology and Chemistry, v. 71, p. 46-51.

U.S. Environmental Protection Agency, 2002, Method 1631, Revision E: Mercury in Water by Oxidation, Purge and Trap, and Cold Vapor Atomic Fluorescense Spectrometry: Washington, D.C., U.S. Environmental Protection Agency, EPA-821-R-02-019, 38 p.

U.S. Environmental Protection Agency, 2004, Revised assessment of detection and quantitation approaches: Washington, D.C., U.S. Environmental Protection Agency, EPA-821-B-04-005, 254 p.

Wang, W., and Fisher, N.S., 1999, Delineating metal accumulation pathways for marine invertebrates: Science of the Total Environment, v. 237, p. 459-472.

Weesner, F.M., 1960, General zoological microtechniques: Baltimore, Maryland, The Waverly Press, Inc., $230 \mathrm{p}$.

Wellise, C., Luoma, S.N., Cain, D.J., Brown, C., Hornberger, M., and Bouse, R., 1999, Near-field receiving water monitoring of trace metals in clams (Macoma balthica) and sediments near the Palo Alto and San Jose/Sunnyvale Water Quality Control Plants in South San Francisco Bay; 1998: U.S. Geological Survey Open-File Report 99-455, 101 p. 


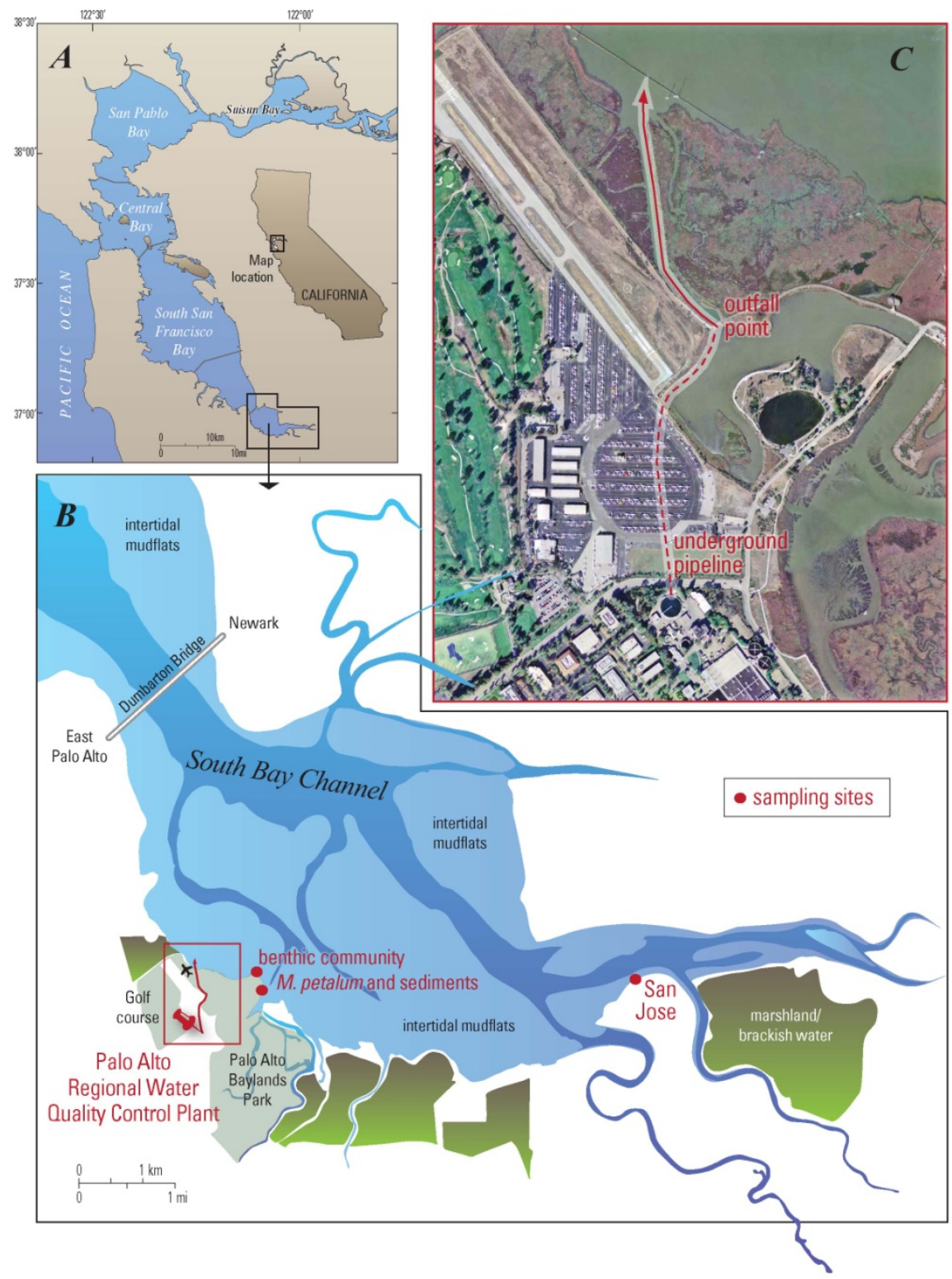

Figure 1. Location of the Palo Alto sampling site in South San Francisco Bay, Calif.

A. Sampling area within the greater San Francisco Bay region.

B. The intertidal mudflats are shaded light blue, subtidal in dark blue, and marshland/brackish water in green/brown. The benthic community and $M$. petalum and sediments points make up the Palo Alto sampling site. The San Jose sampling site (inactive) is also shown for reference.

C. Effluent from the Palo Alto Regional Water Quality Control Plant (red thumbtack, insert B) is discharged via underground pipe (dashed red line) until it reaches the mouth of a small channel that connects to the intertidal mudflat approximately $1 \mathrm{~km}$ northwest of the sampling sites. 


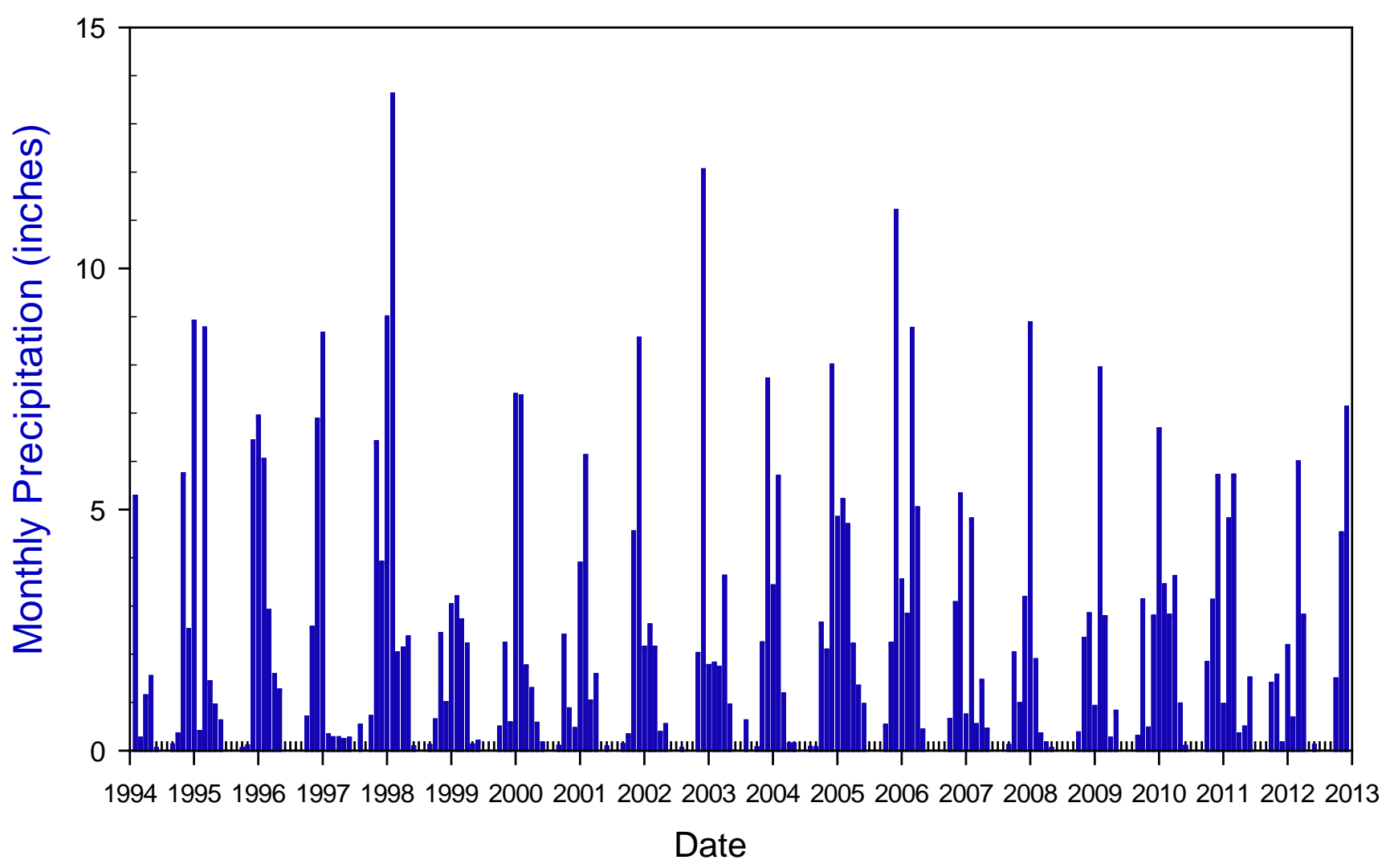

Figure 2. Total monthly rainfall recorded at San Francisco WB AP in San Mateo County, Calif., 1994-2012.

The station (identification SFF) is located at San Francisco International Airport (Latidute $37.62^{\circ} \mathrm{N}$, Longitude $-122.38^{\circ}$ W) and operated by the National Weather Service. 


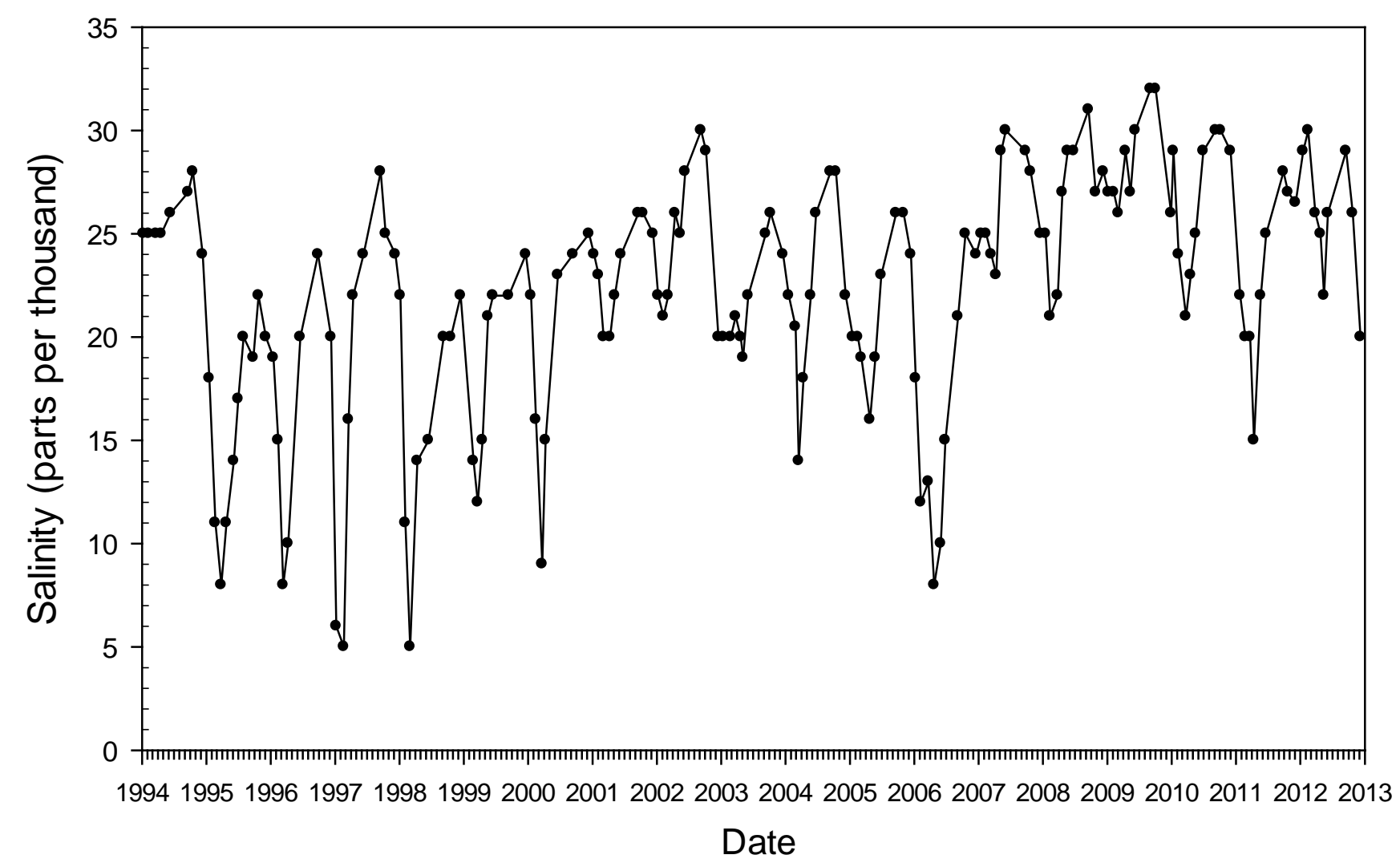

Figure 3. Surface-water salinity at the Palo Alto site, Calif.,1994-2012. 
$A$

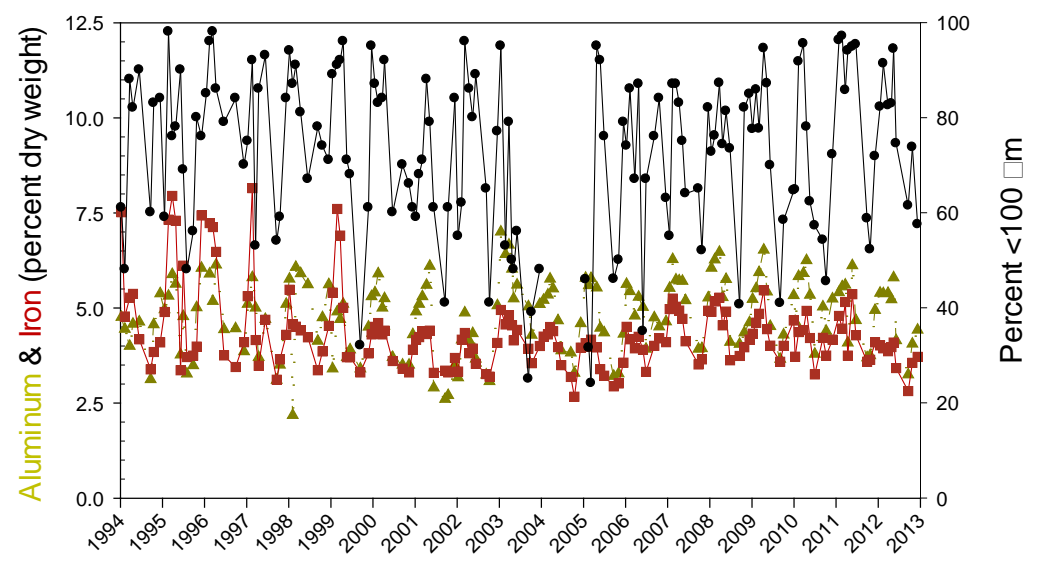

B

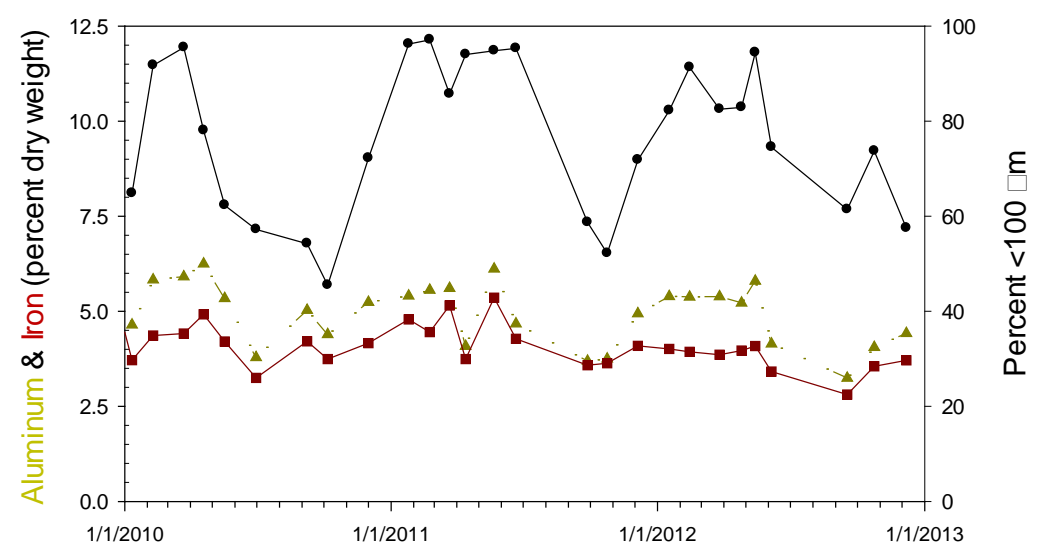

C

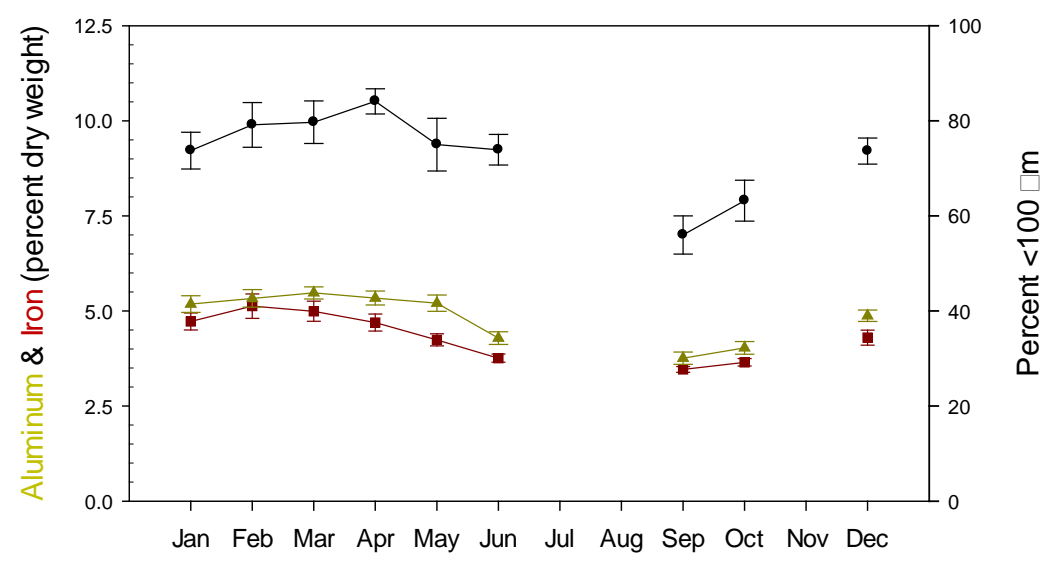

Figure 4. Aluminum, iron, and silt/clay in sediments, Palo Alto, Calif.,1994-2012.

A. Percent aluminum ( $\boldsymbol{\Delta})$, iron ( $\mathbf{\square})$ (extracted by near-total digest), and siltclay $(<100 \mu \mathrm{m})(\mathbf{0})$. Data on percent fines for 2004 contain unquantifiable biases due to errors in sample processing and, therefore, have been censored.

B. Data for the past 3 years (2010-2012).

C. The monthly mean of all samples collected from 1994-2012, illustrating the general seasonal variation in Al, Fe, and percent fine sediments. Collections are not made in July, August, and November. The error bar is the standard error of the mean (SEM). 
$A$
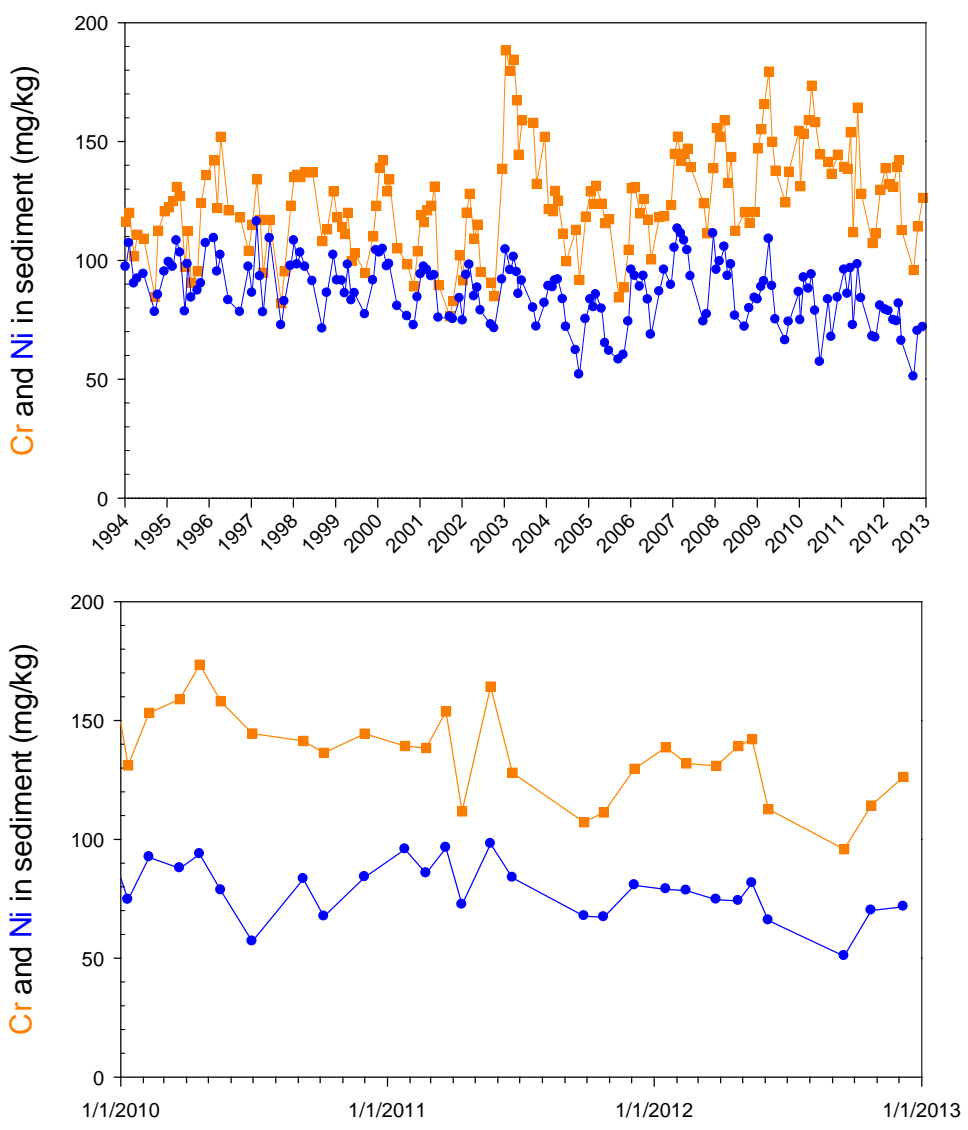

$C$

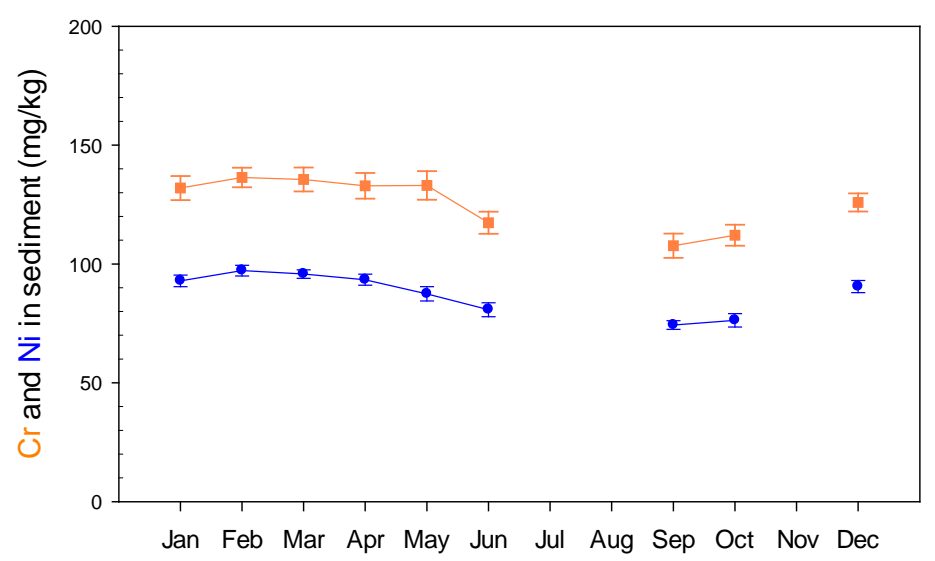

Figure 5. Chromium and nickel in sediments, Palo Alto, Calif., 1994-2012.

A. Concentrations of chromium $(\mathrm{Cr})(\square)$ and nickel $(\mathrm{Ni})(\mathbf{0})$ extracted by near-total digest.

B. Data for the past 3 years (2010-2012).

C. The monthly mean of all samples collected from 1994-2012, illustrating the general seasonal variation in $\mathrm{Cr}$ and $\mathrm{Ni}$. Collections are not made in July, August, and November. The error bar is the standard error of the mean (SEM). 
A

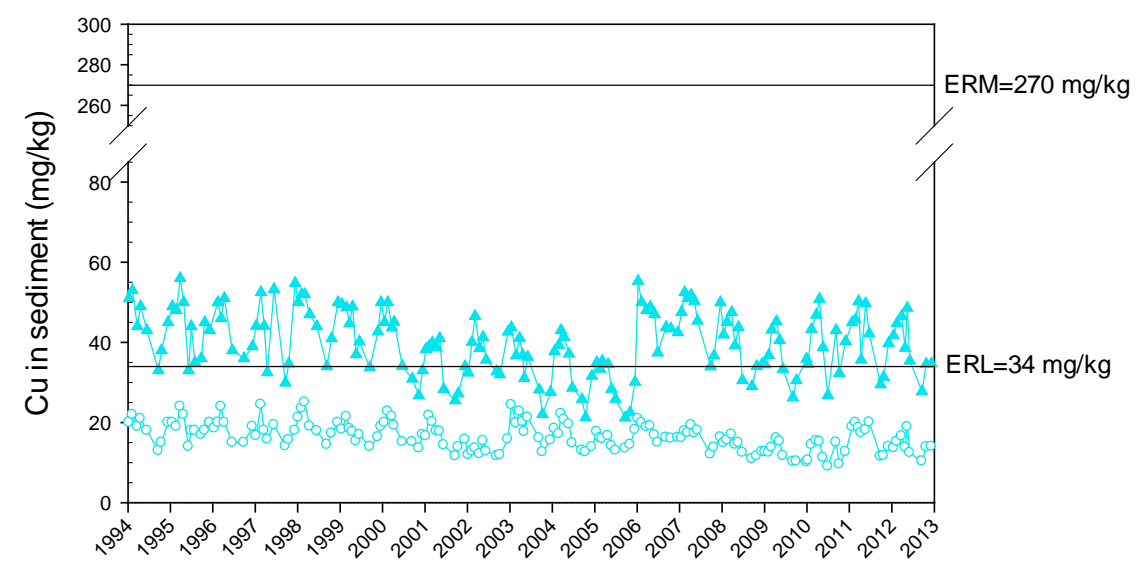

$B$

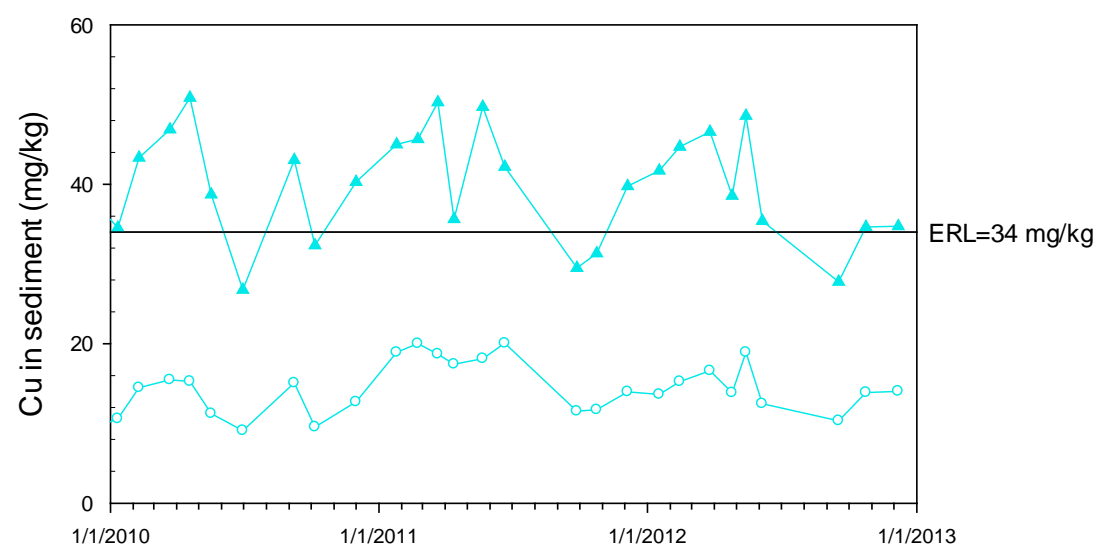

C

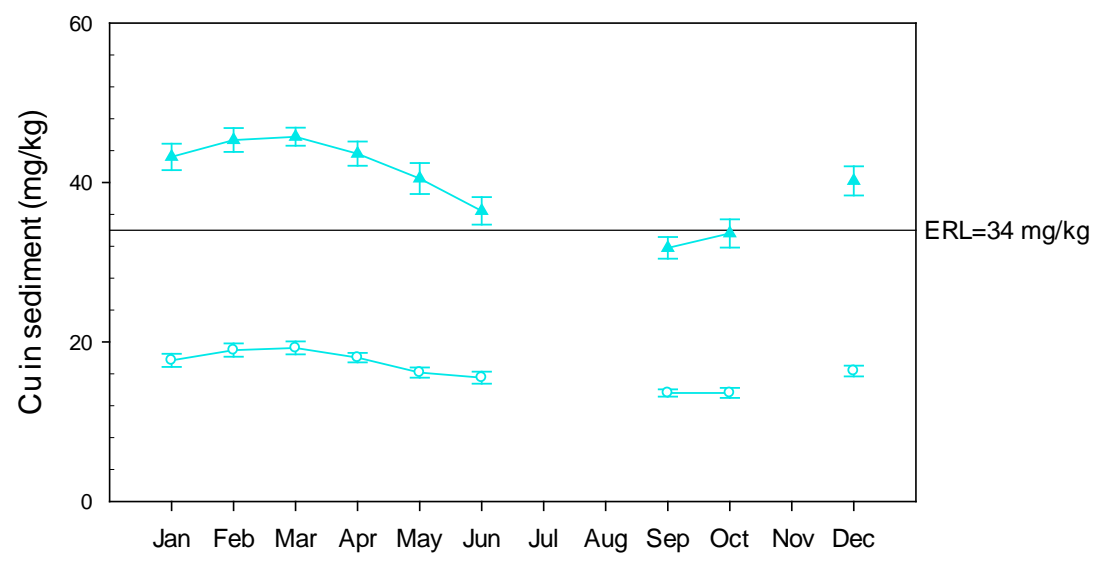

Figure 6. Copper in sediments, Palo Alto, Calif., 1994-2012.

A. Near-total $(\triangle)$ and partial-extractable $(\bigcirc)$ copper.

B. Data for the past 3 years (2010-2012).

C. The monthly mean of all samples collected from 1994-2012, illustrating the general seasonal variation in Cu. Collections are not made in July, August, and November. The error bar is the standard error of the mean (SEM).

The ERL is the concentration below which the expected incidence of adverse effects is low (9 percent).

The ERM is the concentration above which the expected incidence of adverse effects is high (84 percent). 
$A$

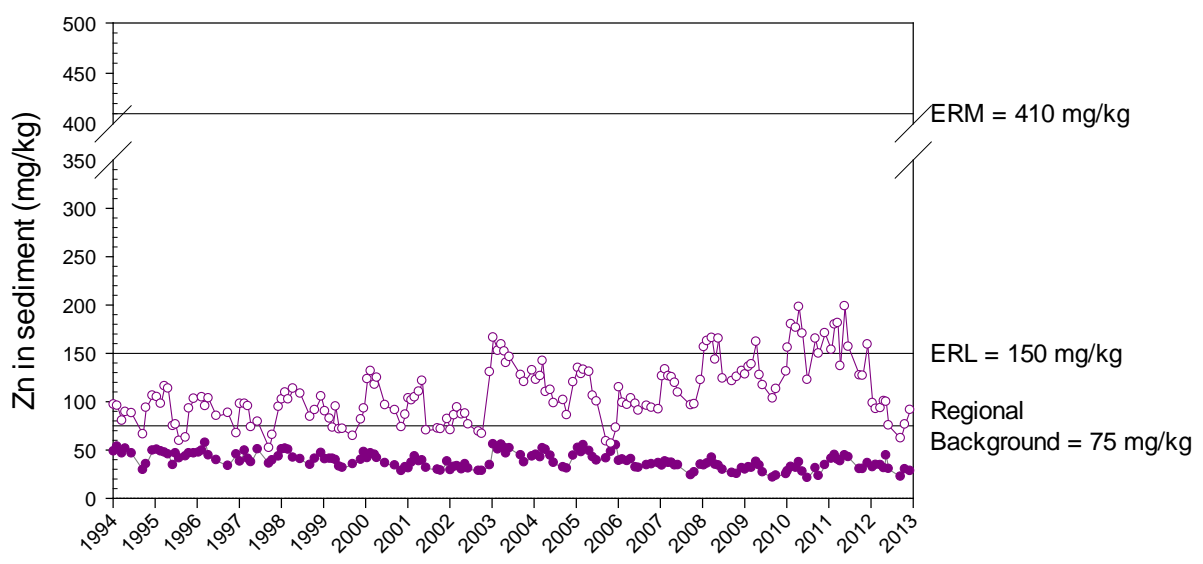

B

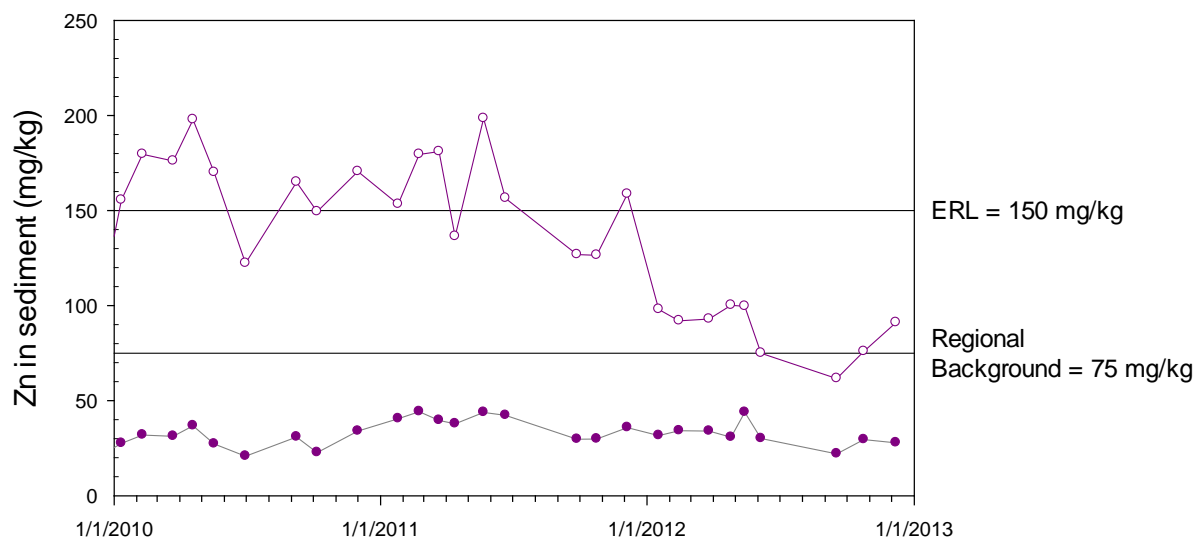

$C$

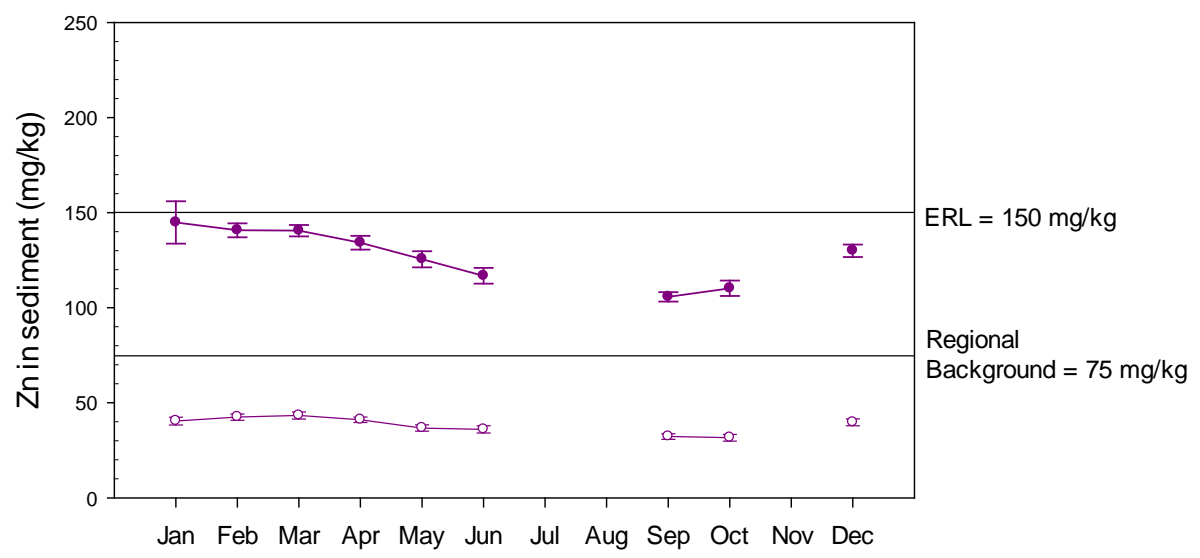

Figure 7. Zinc in sediments, Palo Alto, Calif., 1994-2012.

A. Near-total $(\bullet)$ and partial-extractable $(O)$ zinc.

B. Data for the past 3 years (2010-2012).

C. The monthly mean of all samples collected from 1994-2012, illustrating the general seasonal variation in Zn. Collections are not made in July, August, and November. The error bar is the standard error of the mean (SEM).

The ERL is the concentration below which the expected incidence of adverse effects is low (6 percent).

The ERM is the concentration above which the expected incidence of adverse effects is high (70 percent). 
$A$

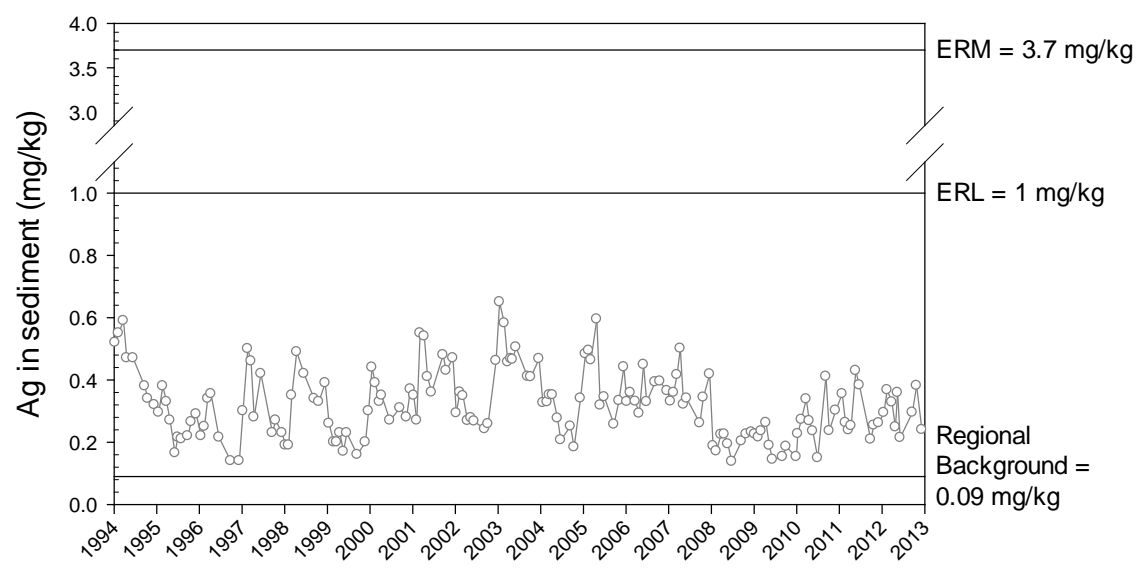

B

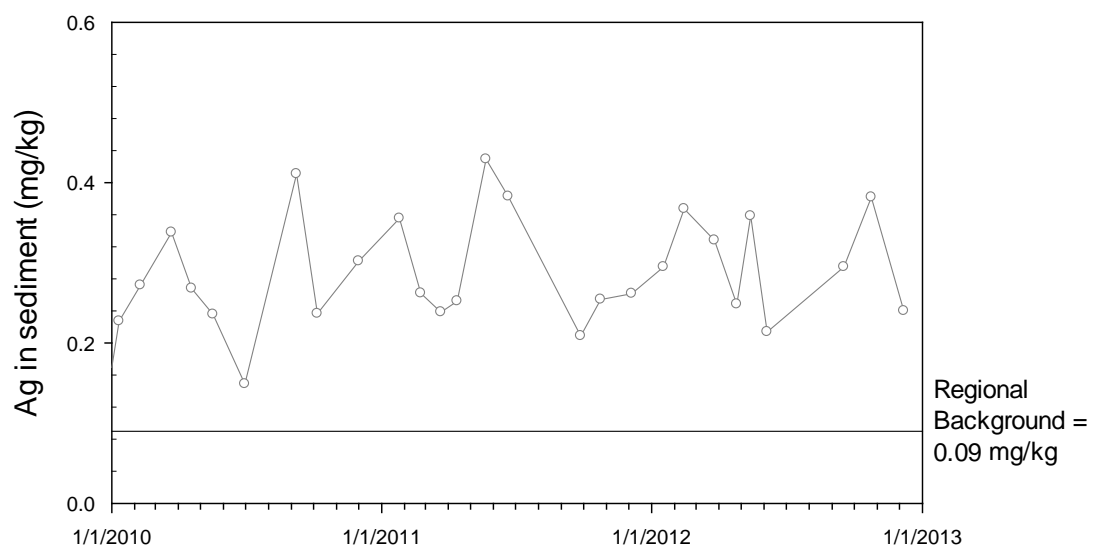

C

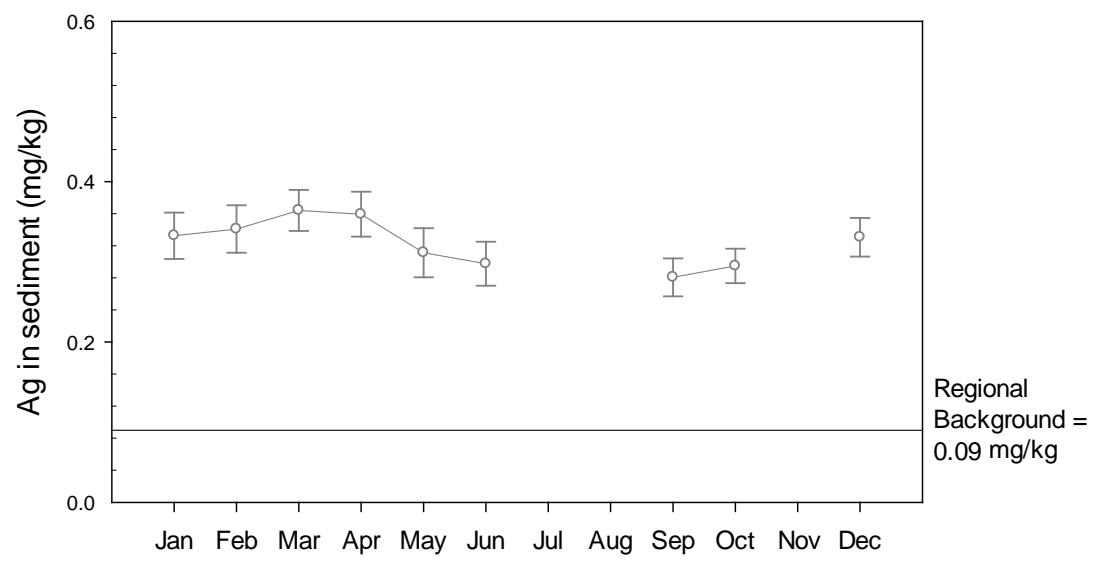

Figure 8. Silver in sediments, Palo Alto, Calif., 1994-2012.

A. Data represent partial-extractable silver (treatment with $0.6 \mathrm{~N}$ hydrochloric acid).

B. Data for the past 3 years (2010-2012).

C. The monthly mean of all samples collected from 1994-2012, illustrating the general seasonal variation in Ag. Collections are not made in July, August, and November. The error bar is the standard error of the mean (SEM).

The ERL is the concentration below which the expected incidence of adverse effects is low (3 percent).

The ERM is the concentration above which the expected incidence of adverse effects is high (93 percent). 
$A$

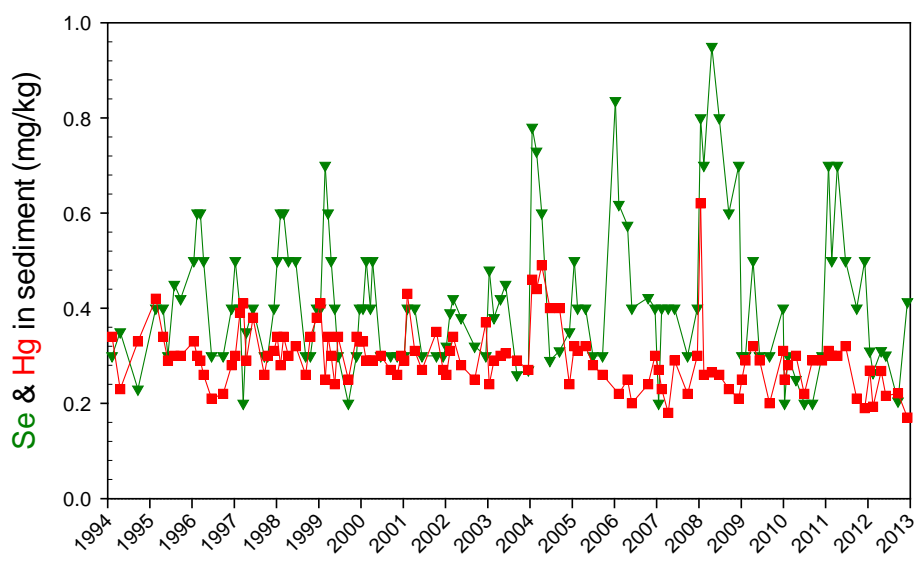

B

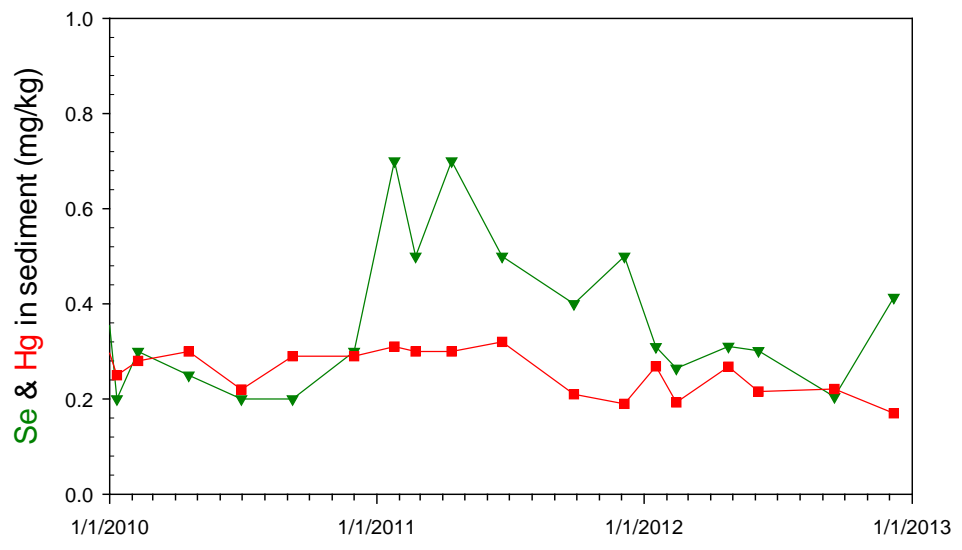

C

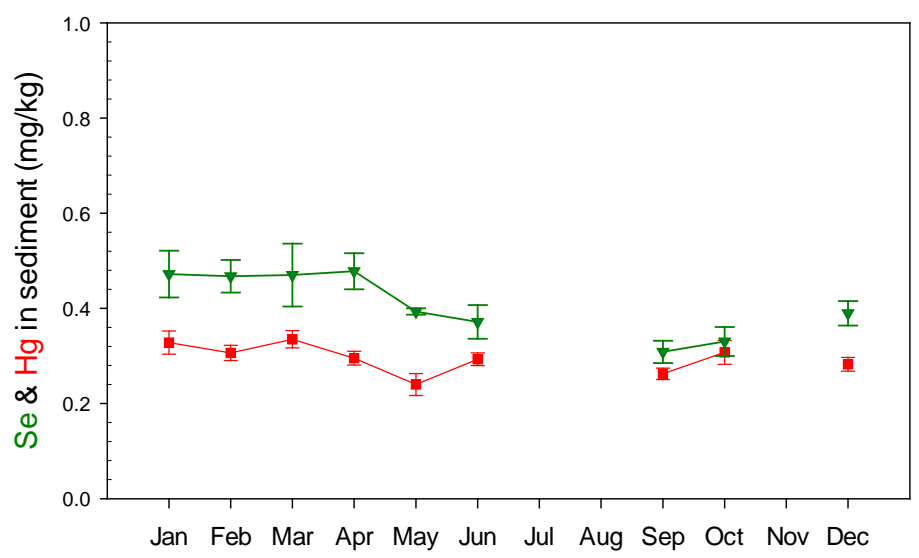

Figure 9. Selenium and mercury in sediments, Palo Alto, Calif., 1994-2012.

A. Selenium ( $\nabla)$; mercury ( $\square)$.

B. Data for the past 3 years (2010-2012).

C. The monthly mean of all samples collected from 1994-2012, illustrating the general seasonal variation in Se and $\mathrm{Hg}$. Collections are not made in July, August, and November. The error bar is the standard error of the mean (SEM). 


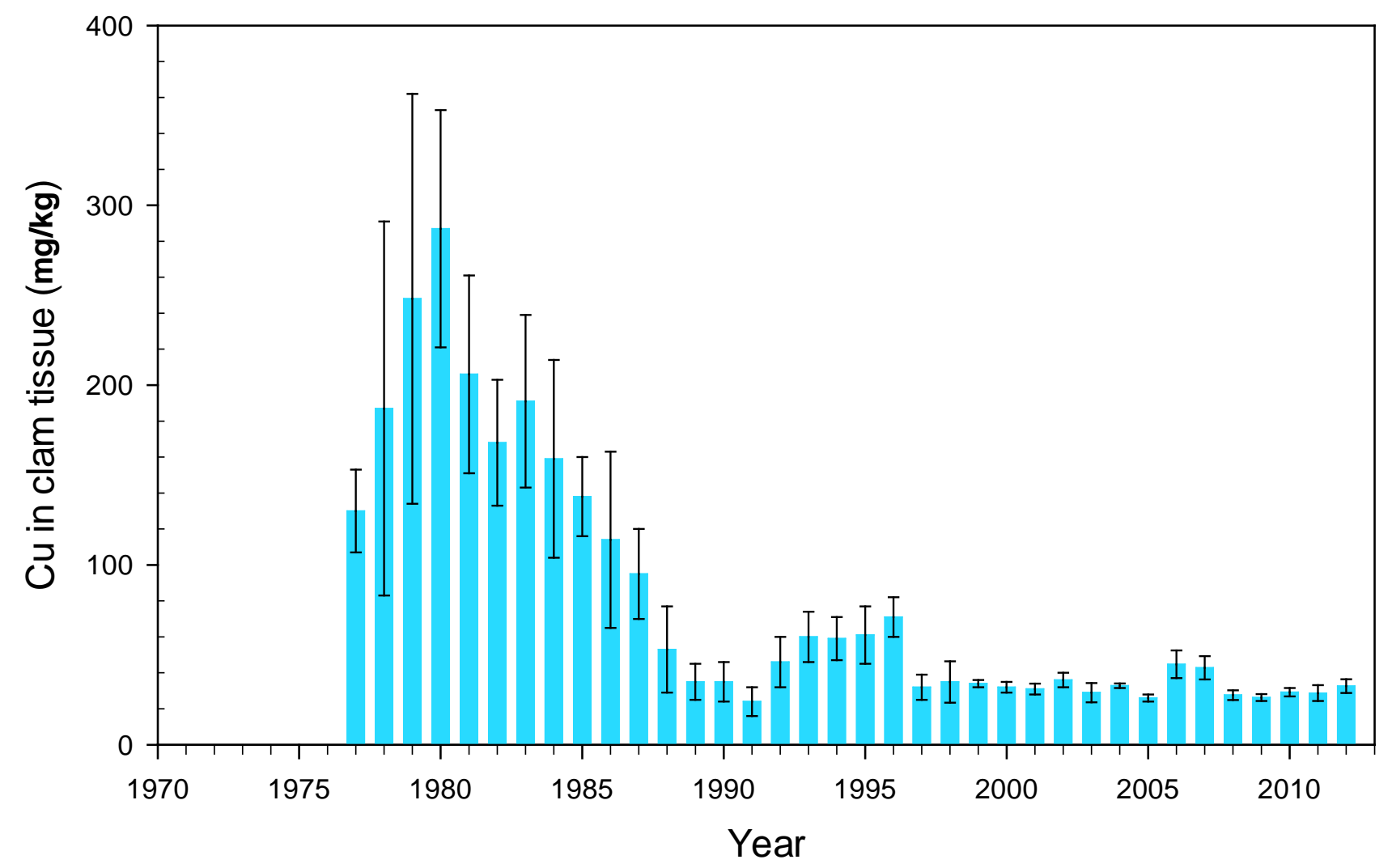

Figure 10. Annual mean copper concentrations in the clam Macoma petalum, Palo Alto, Calif., 1977-2012.

Values are the annual (grand) means for 7 to 12 separate samples per year and error bars are standard errors of those means (SEM). 


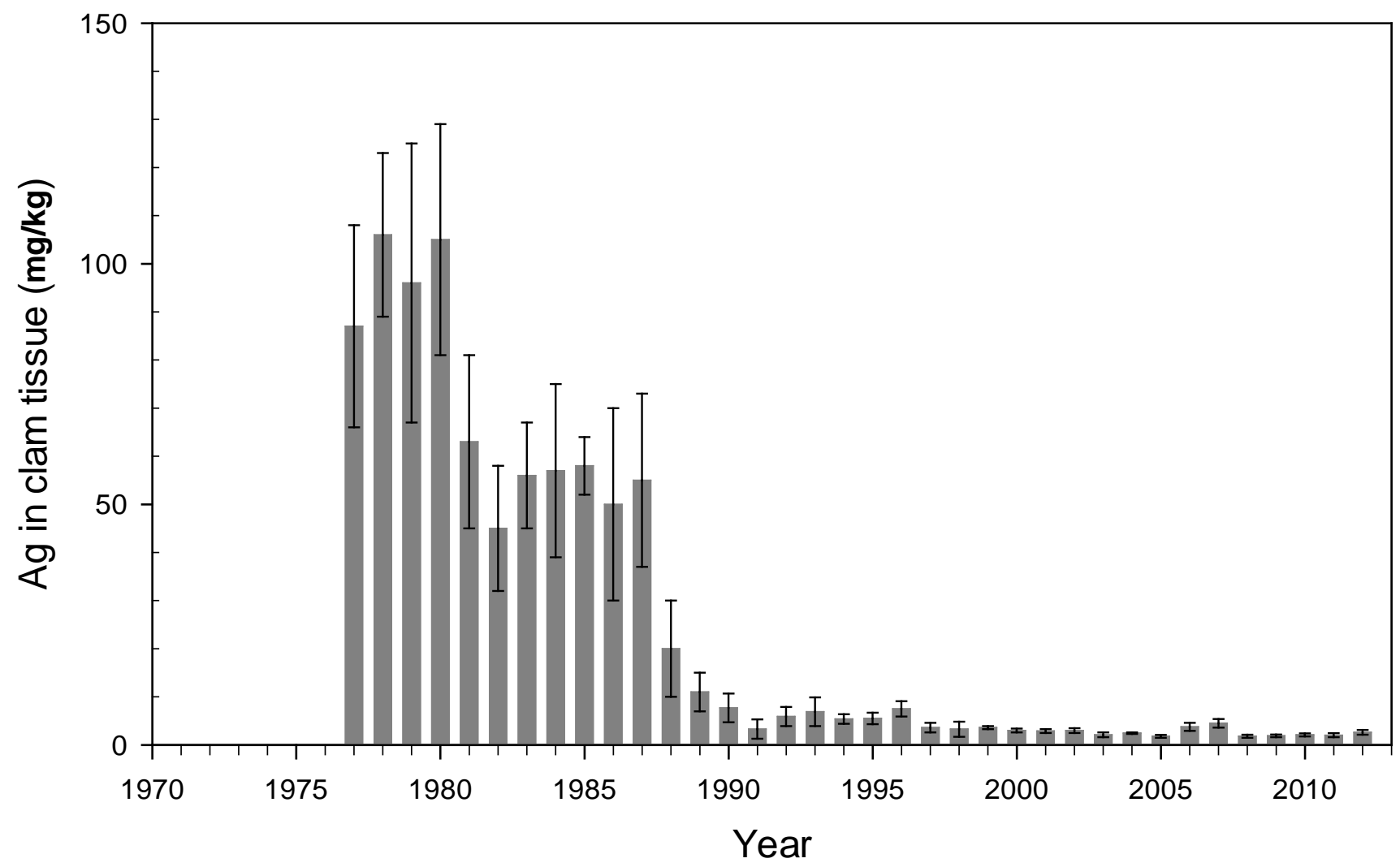

Figure 11. Annual mean silver concentrations in the clam Macoma petalum, Palo Alto, Calif., 1977-2012.

Values are the annual (grand) means for 7 to 12 separate samples per year and error bars are standard errors of those means (SEM). 
$A$
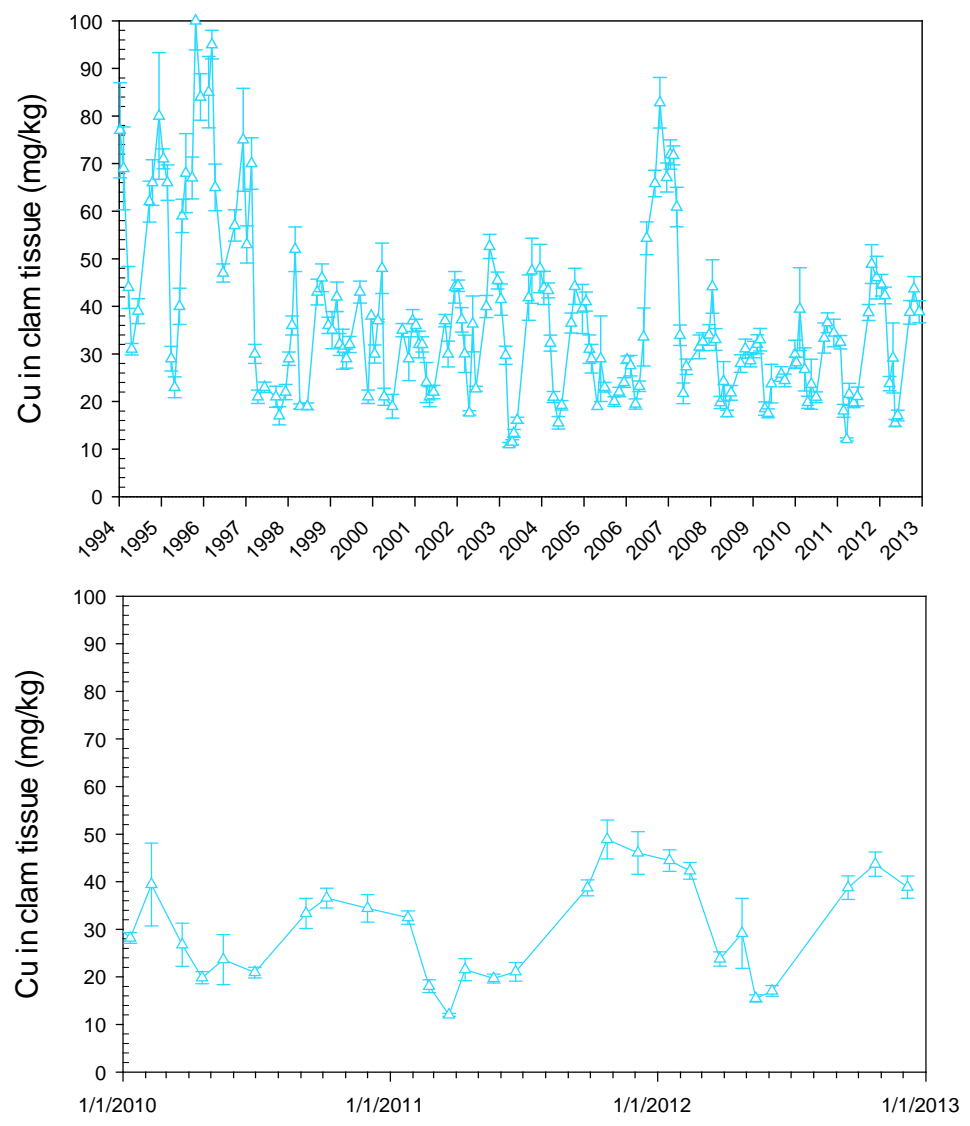

C

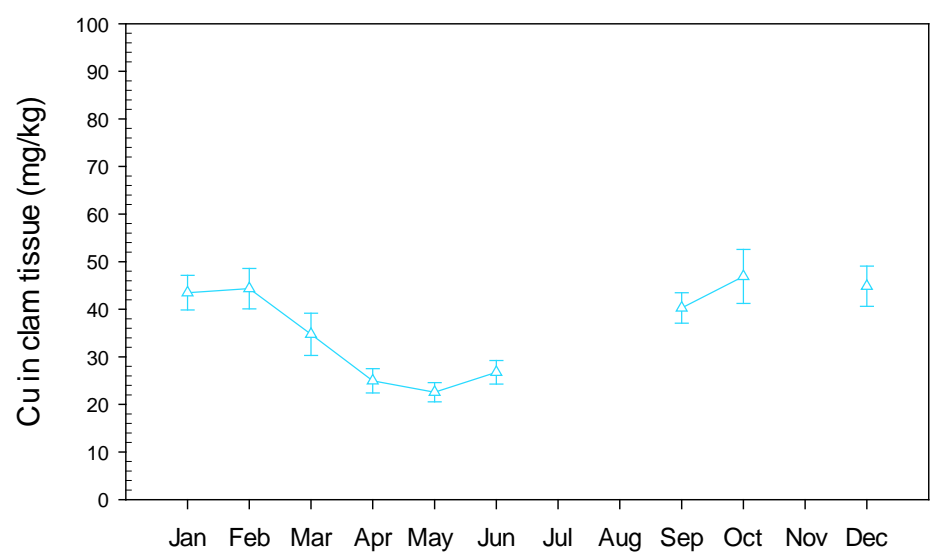

Figure 12. Copper concentrations in the clam Macoma petalum, Palo Alto, Calif., 1994-2012.

A. Each value is the mean concentration for the sample collected on a given date. The error bar is the standard error of the mean (SEM).

B. Data for the past 3 years (2010-2012).

C. The monthly mean of all samples collected from 1994-2012, illustrating the general seasonal variation in Cu. Collections are not made in July, August, and November. The error bar is the standard error of the mean (SEM). 
$A$

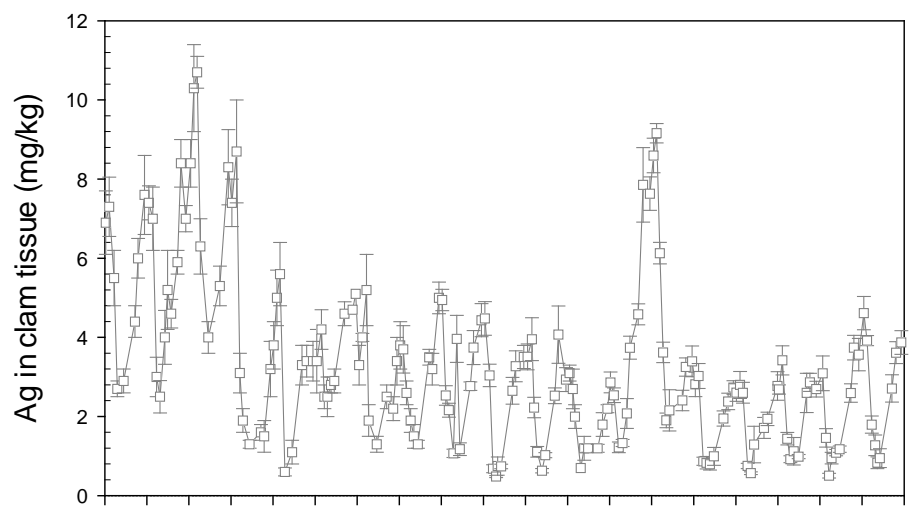

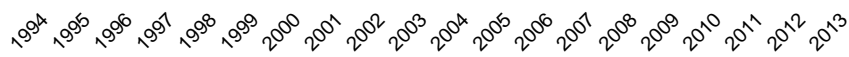

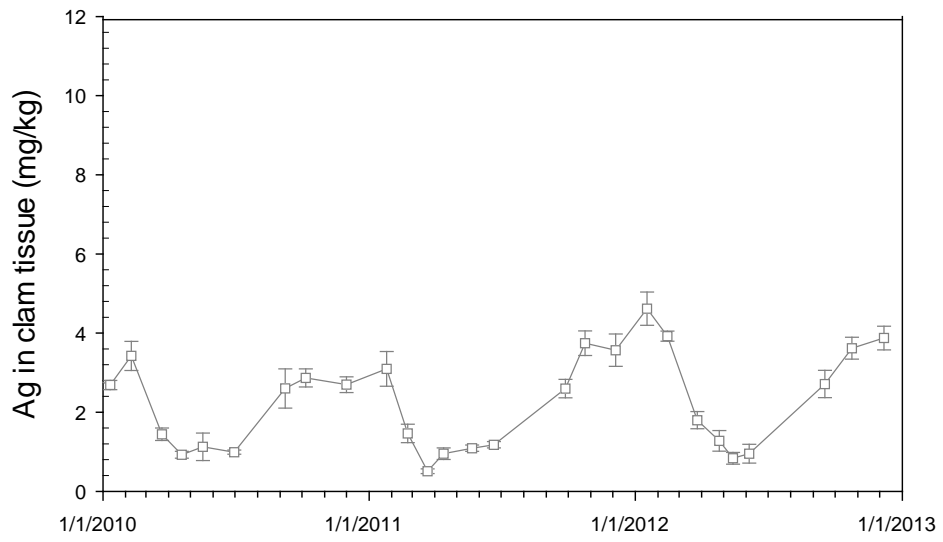

C

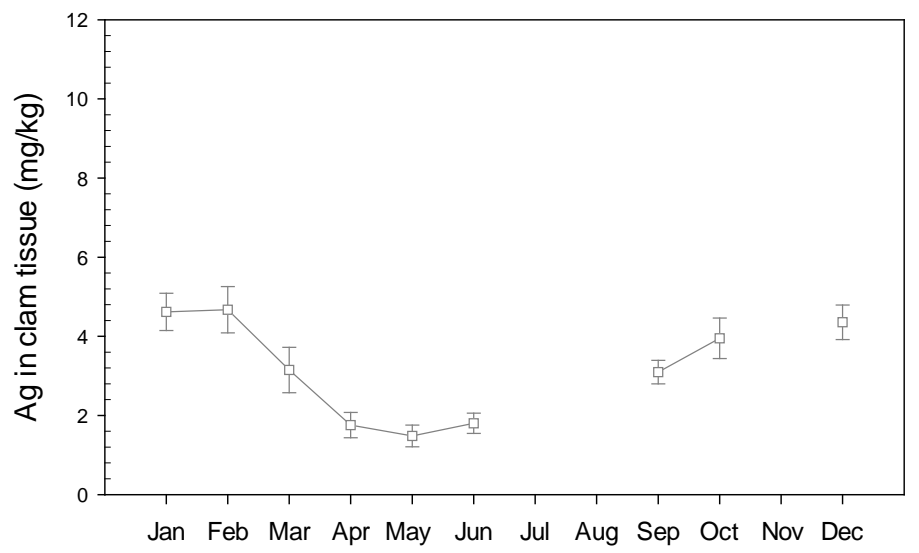

Figure 13. Silver concentrations in the clam Macoma petalum, Palo Alto, Calif., 1994-2012.

A. Each value is the mean concentration for the sample collected on a given date. The error bar is the standard error of the mean (SEM).

B. Data for the past 3 years (2010-2012).

C. The monthly mean of all samples collected from 1994-2012, illustrating the general seasonal variation in Ag. Collections are not made in July, August, and November. The error bar is the standard error of the mean (SEM). 
$A$

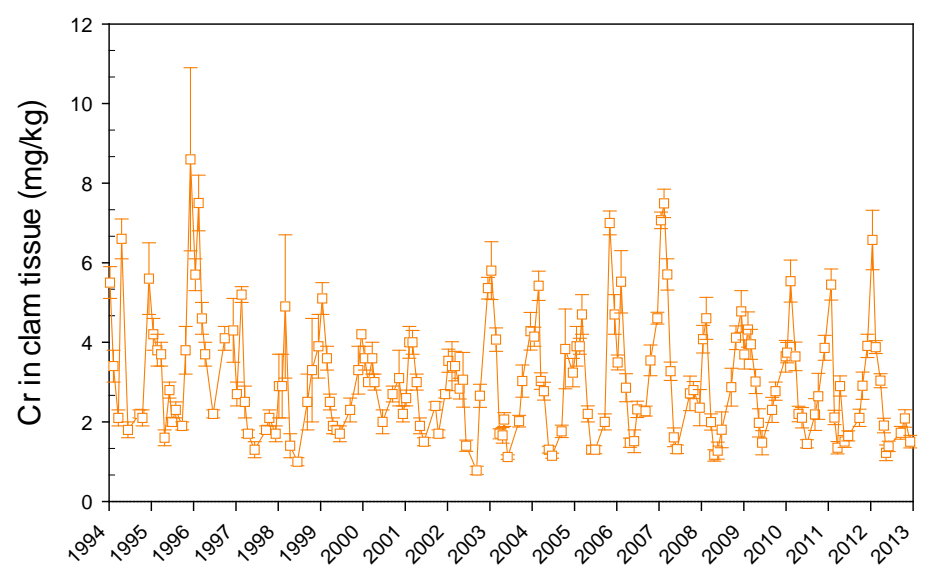

B

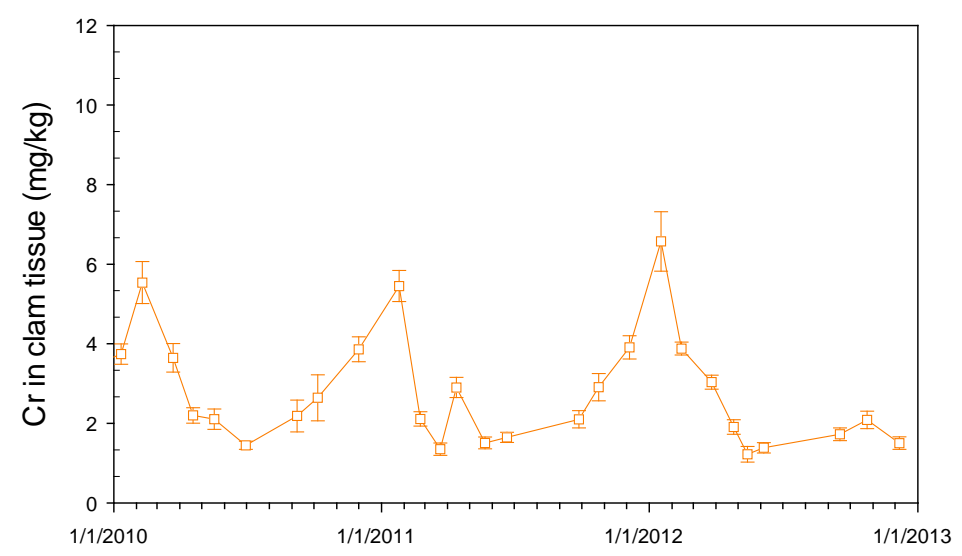

C

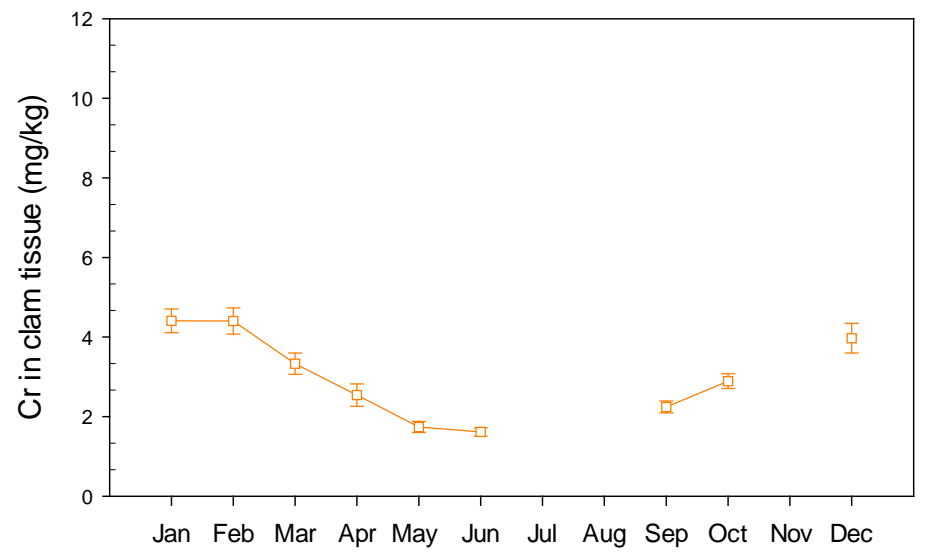

Figure 14. Chromium concentrations in the clam Macoma petalum, Palo Alto, Calif., 1994-2012.

A. Each value is the mean concentration for the sample collected on a given date. The error bar is the standard error of the mean (SEM).

B. Data for the past 3 years (2010-2012).

C. The monthly mean of all samples collected from 1994-2012, illustrating the general seasonal variation in Cr. Collections are not made in July, August, and November. The error bar is the standard error of the mean (SEM). 
$A$

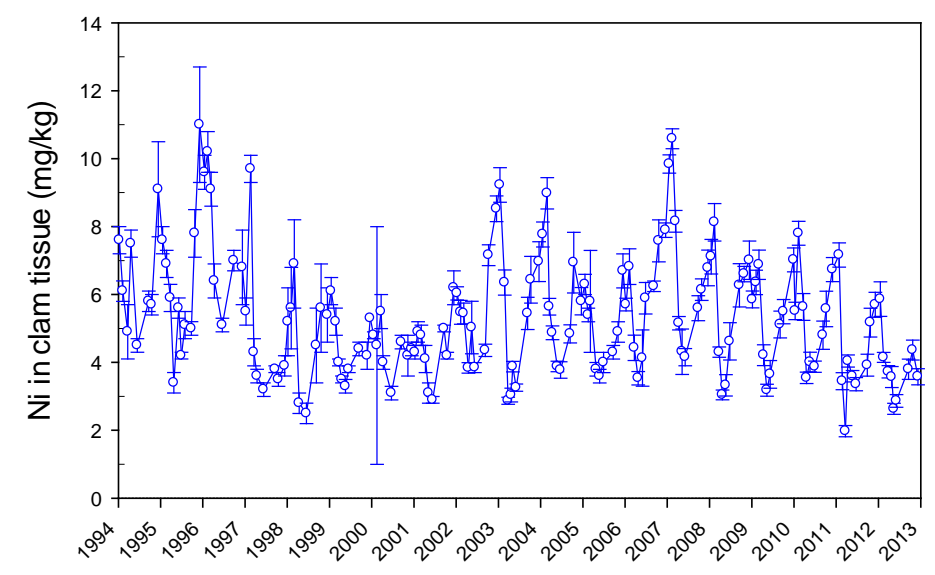

$B$

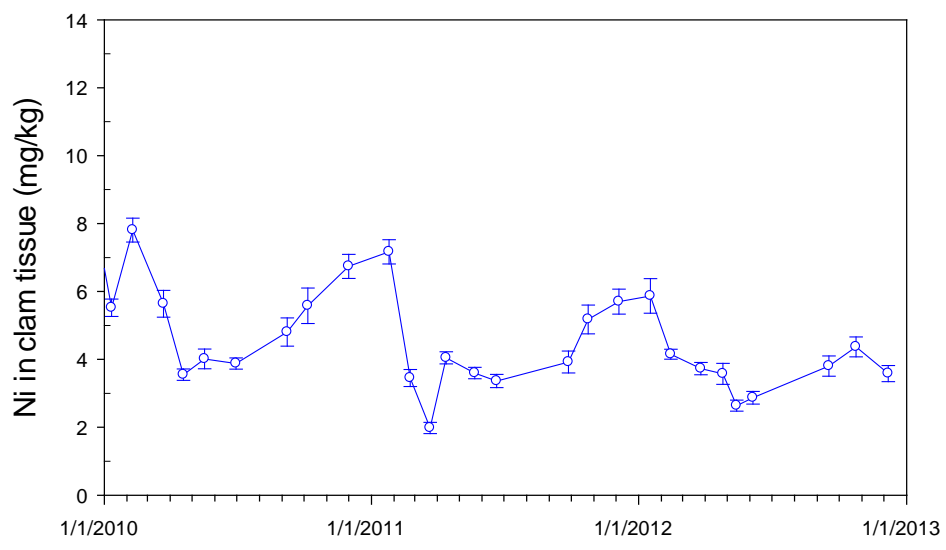

$C$

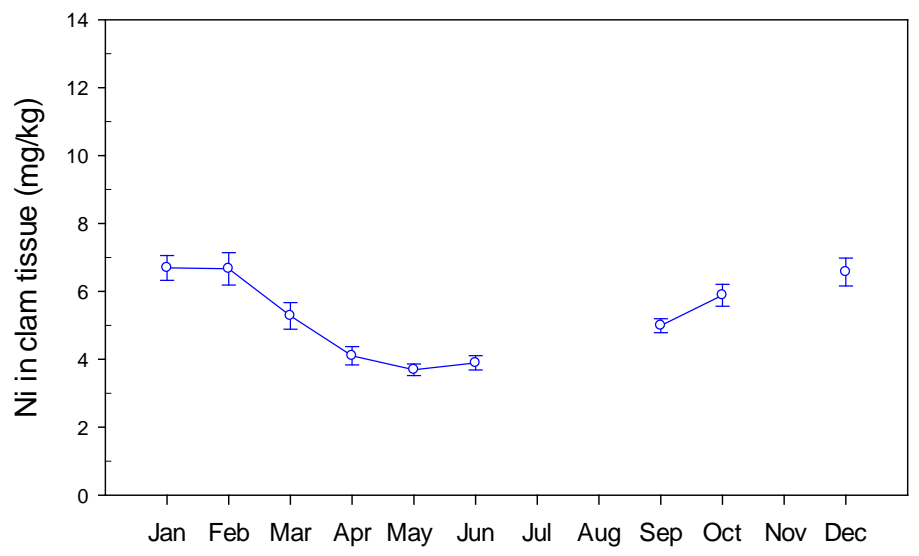

Figure 15. Nickel concentrations in the clam Macoma petalum, Palo Alto, Calif., 1994-2012.

A. Each value is the mean concentration for the sample collected on a given date. The error bar is the standard error of the mean (SEM).

B. Data for the past 3 years (2010-2012).

C. The monthly mean of all samples collected from 1994-2012, illustrating the general seasonal variation in Ni. Collections are not made in July, August, and November. The error bar is the standard error of the mean (SEM). 
$A$

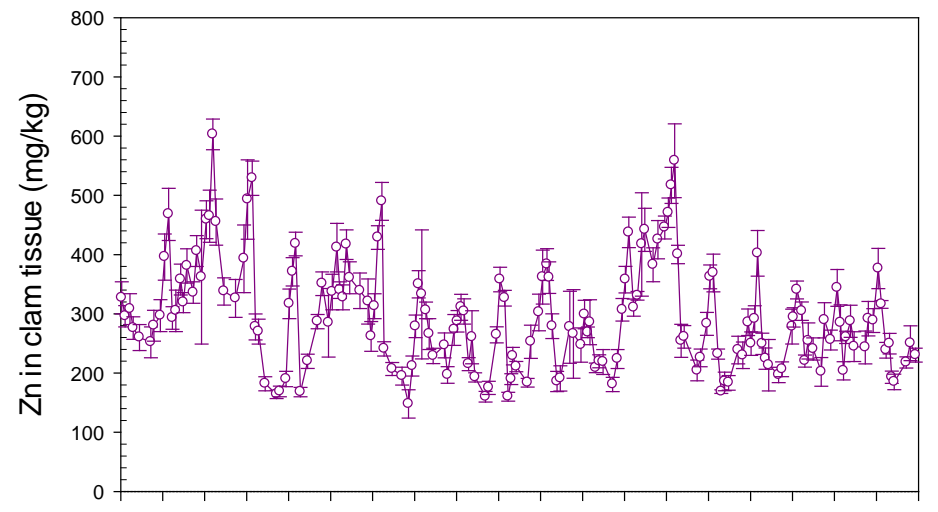

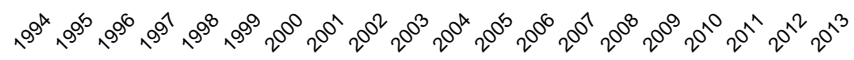

B

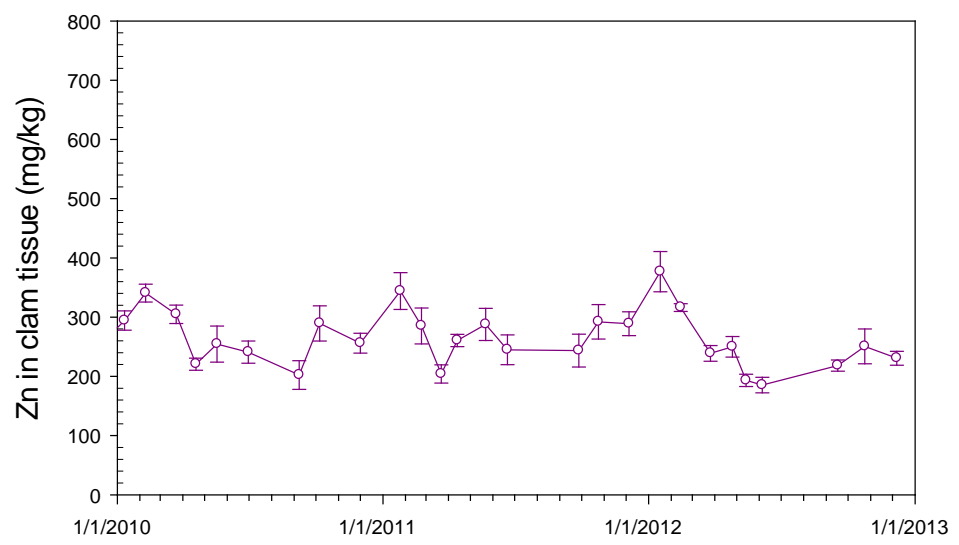

C

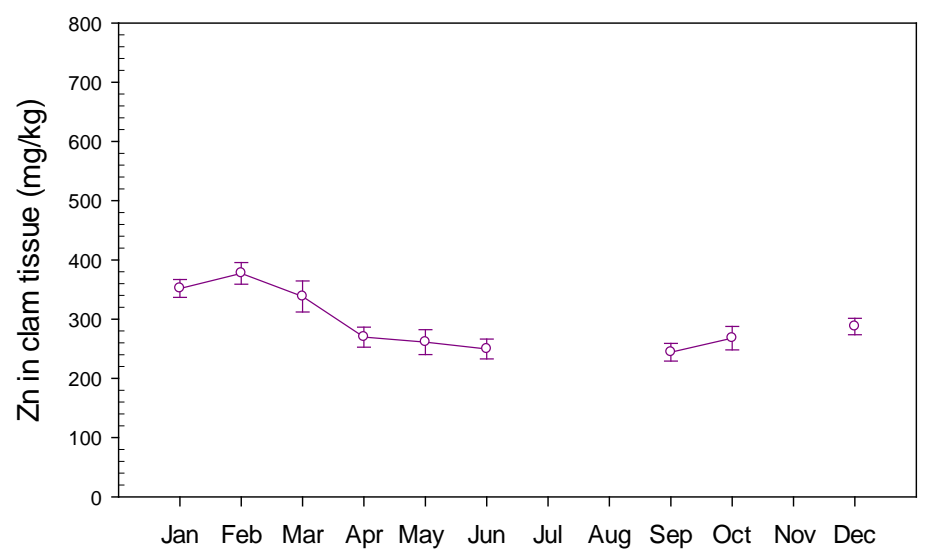

Figure 16. Zinc concentrations in the clam Macoma petalum, Palo Alto, Calif., 1994-2012.

A. Each value is the mean concentration for the sample collected on a given date. The error bar is the standard error of the mean (SEM).

B. Data for the past 3 years (2010-2012).

C. The monthly mean of all samples collected from 1994-2012, illustrating the general seasonal variation in Zn. Collections are not made in July, August, and November. The error bar is the standard error of the mean (SEM). 
$A$

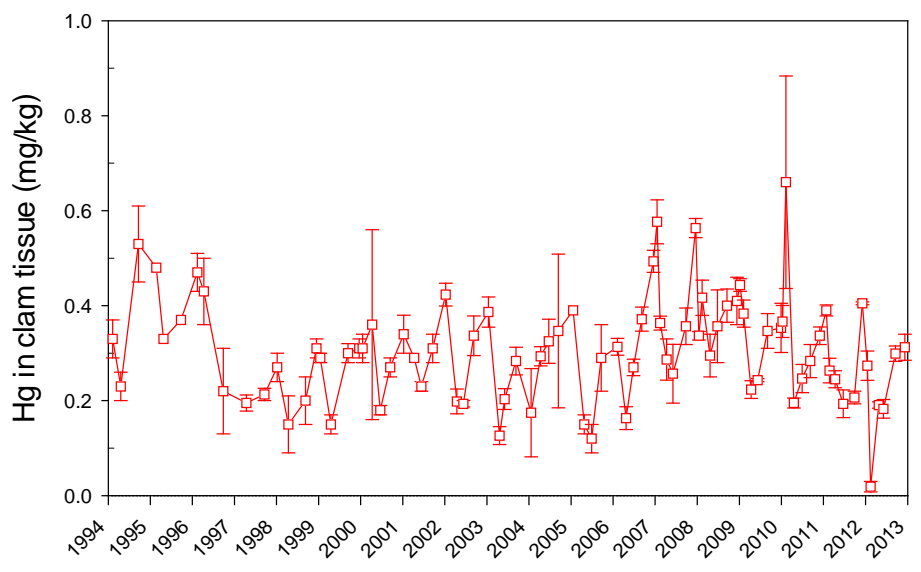

B

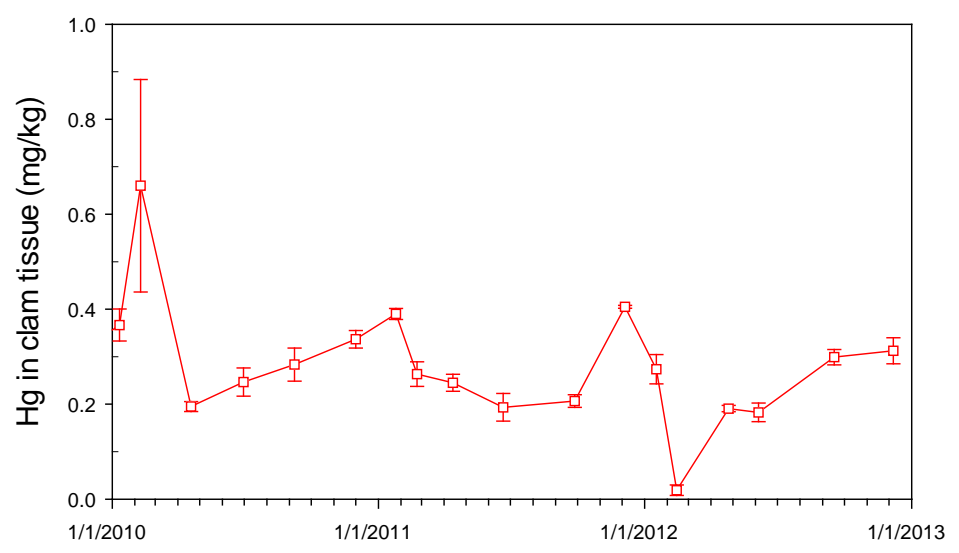

C

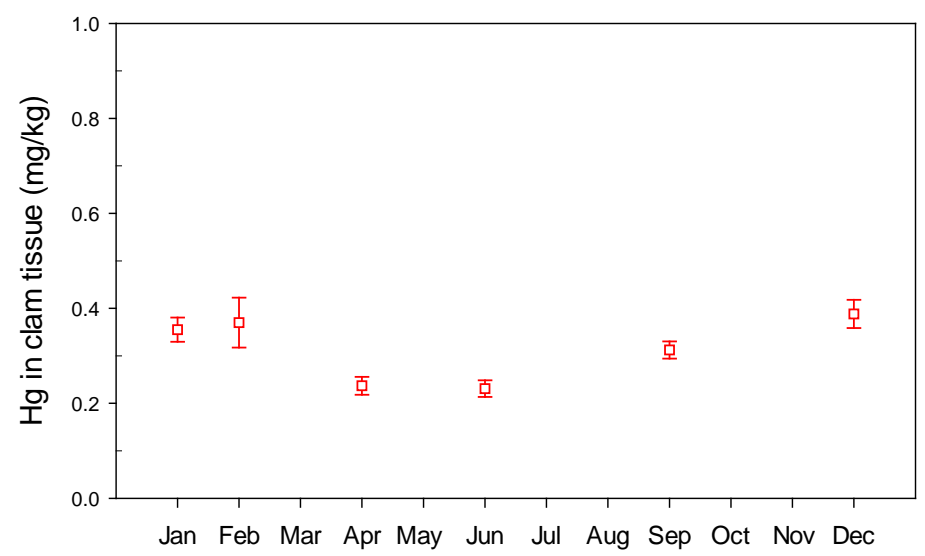

Figure 17. Mercury concentrations in the clam Macoma petalum, Palo Alto, Calif., 1994-2012.

A. Each value is the mean concentration for the sample collected on a given date. The error bar is the standard error of the mean (SEM).

B. Data for the past 3 years (2010-2012).

C. The monthly mean of all samples collected from 1994-2012, illustrating the general seasonal variation in $\mathrm{Hg}$. Collections are not made in March, May, July, August, October, and November. The error bar is the standard error of the mean (SEM). 
$A$

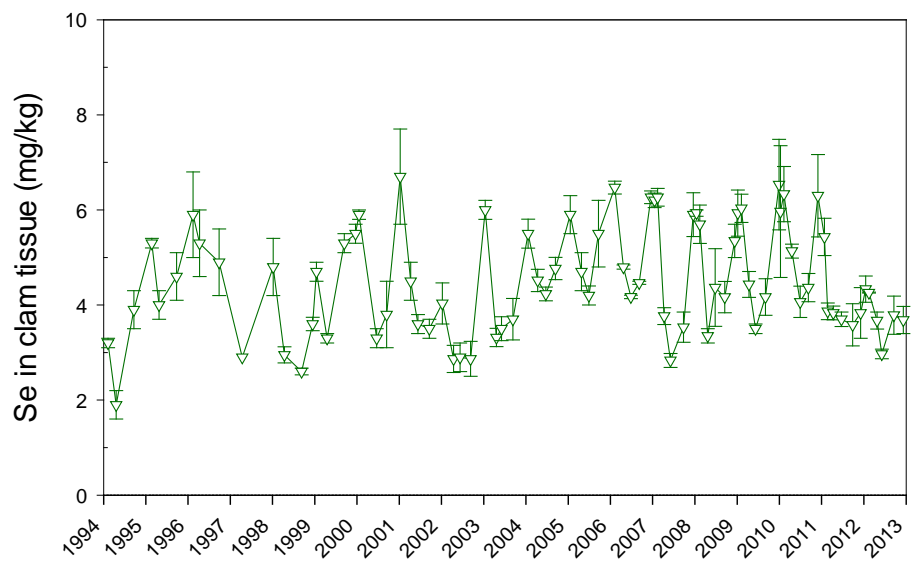

B

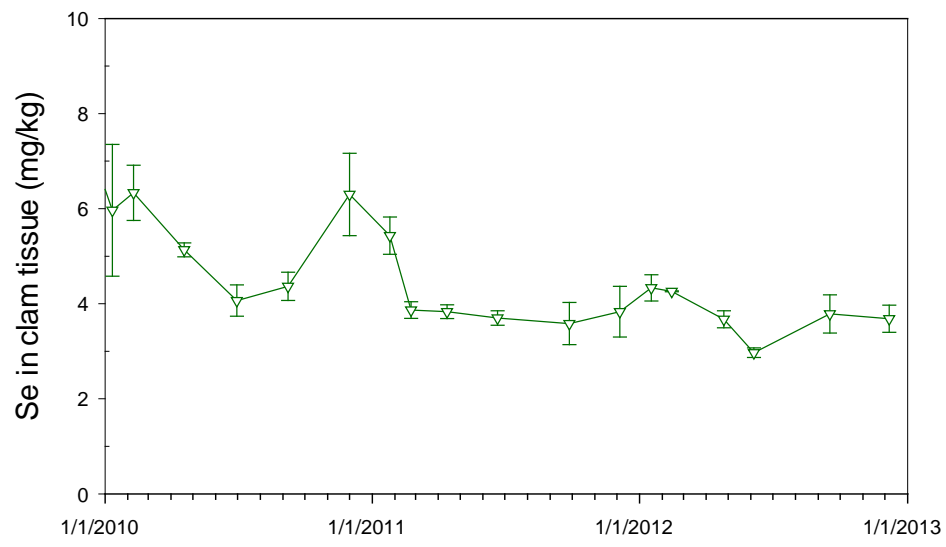

C

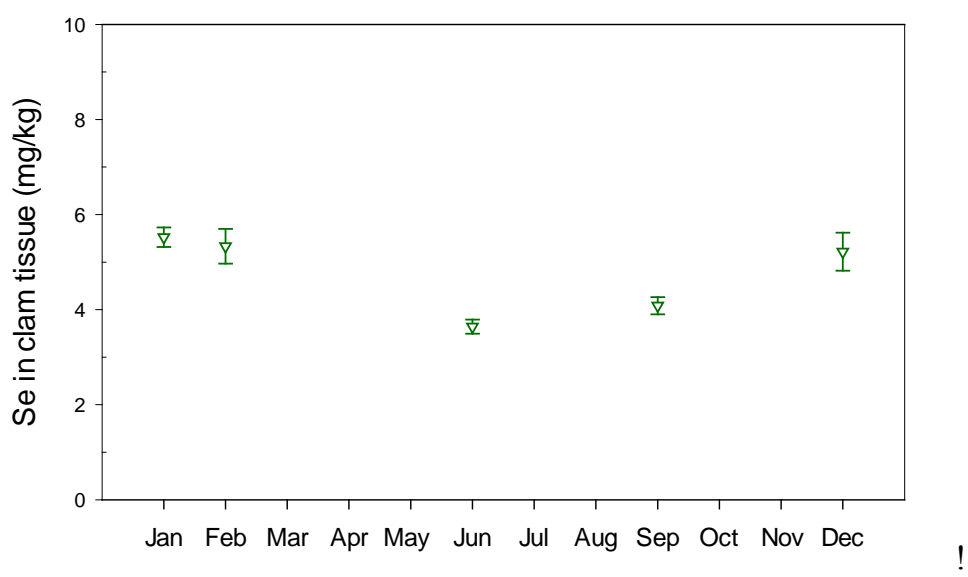

Figure 18. Selenium concentrations in the clam Macoma petalum, Palo Alto, Calif., 1994-2012.

A. Each value is the mean concentration for the sample collected on a given date. The error bar is the standard error of the mean (SEM).

B. Data for the past 3 years (2010-2012).

C. The monthly mean of all samples collected from 1994-2012, illustrating the general seasonal variation in Se. Collections are not made in March, May, July, August, October, and November. The error bar is the standard error of the mean (SEM). 
$A$
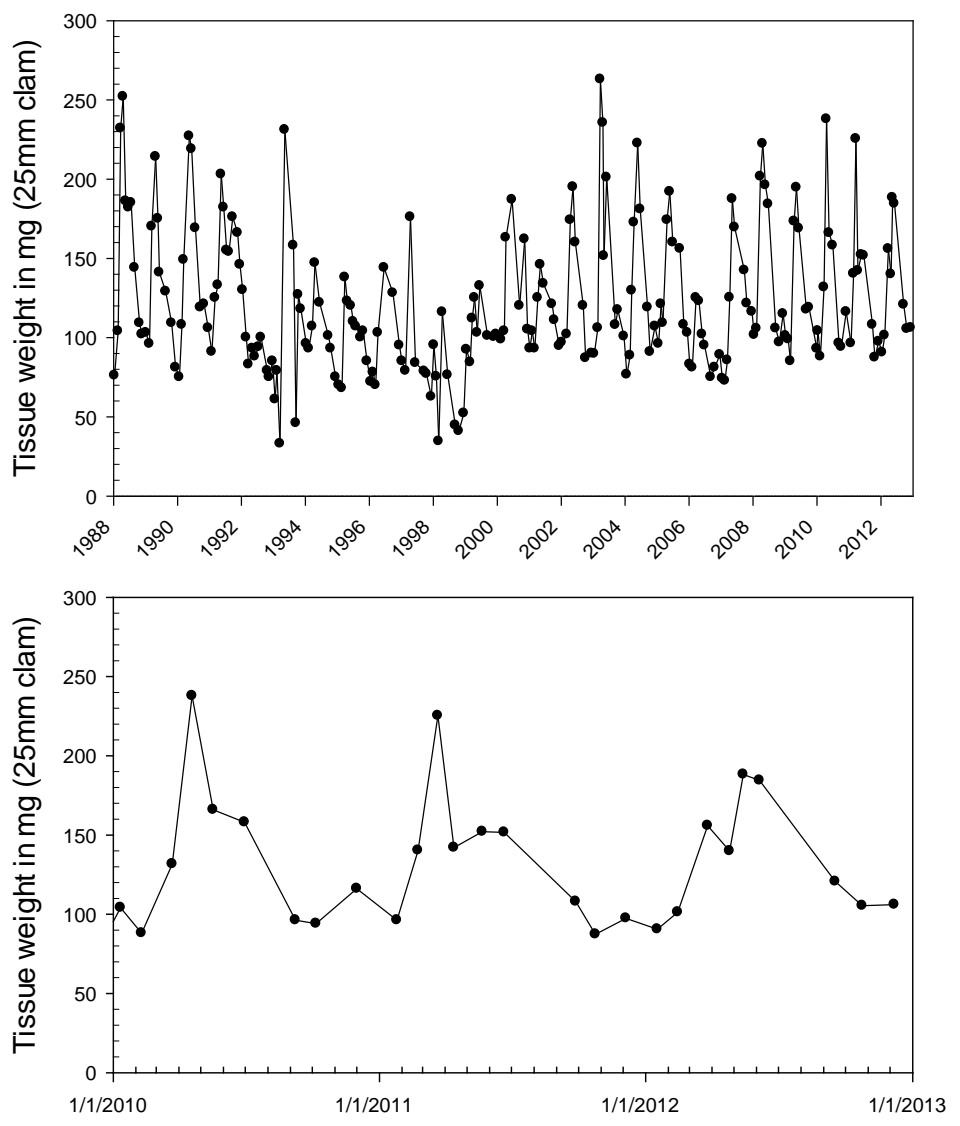

C

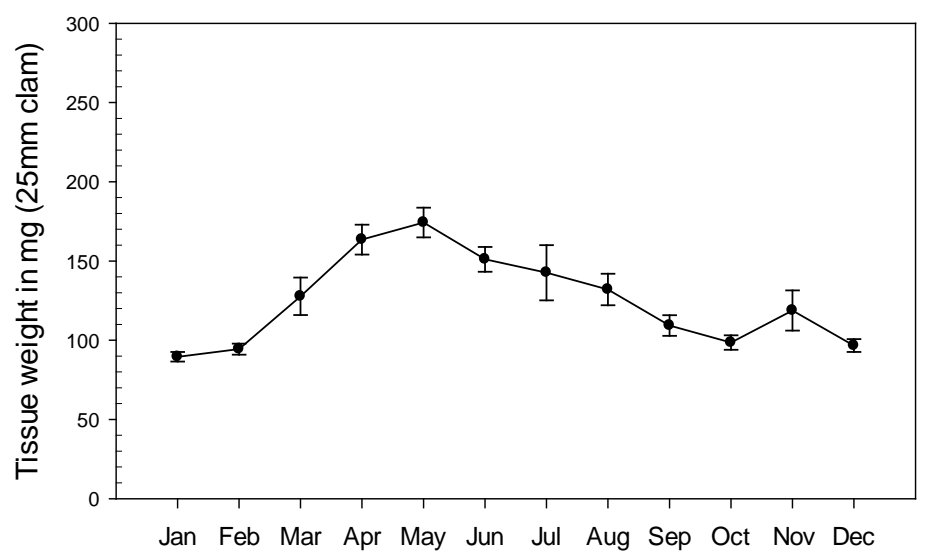

Figure 19. Condition index of the clam Macoma petalum, Palo Alto, Calif., 1988-2012.

A. The condition index $(\mathrm{Cl})$ is defined as the weight (milligrams) of the soft tissues for an individual clam having a shell length of 25 $\mathrm{mm}$.

B. Condition index over the past 3 years (2010-2012).

C. The monthly mean of all samples collected from 1988-2012, illustrating the general seasonal variation in condition index. The error bar is the standard error of the mean (SEM). 


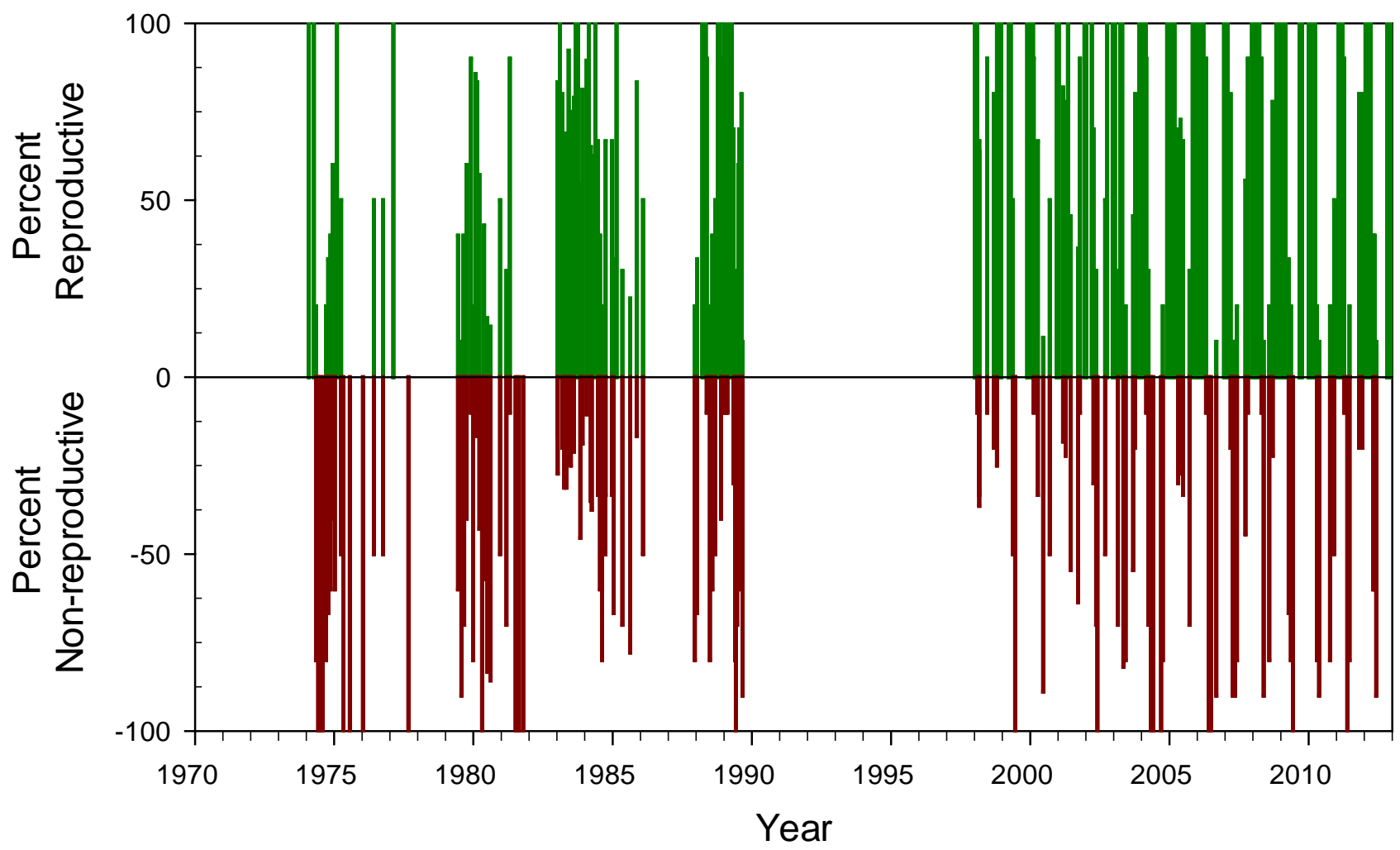

Figure 20. Reproductive activity of the clam Macoma petalum, Palo Alto, Calif., 1974-2012.

Values are the percent of individuals that were either reproductively inactive (nonreproductive; shown in red) or in various stages of reproduction (reproductive; shown in green). The percent of non-reproductive individuals is reported as a negative value. 


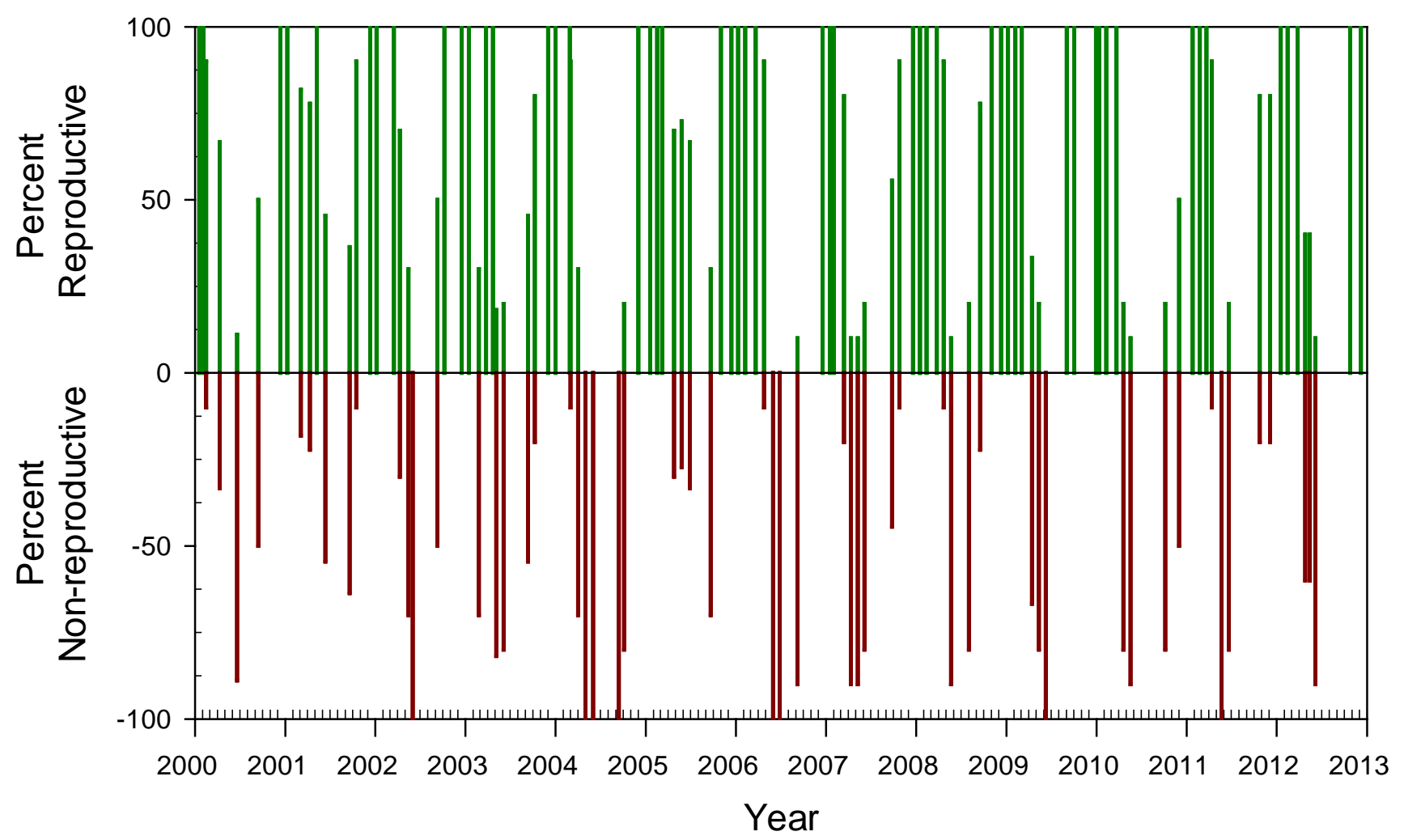

Figure 21. Reproductive activity of the clam Macoma petalum, Palo Alto, Calif., 2000-2012.

Values are the percent of individuals that were either reproductively inactive (nonreproductive; shown in red) or in various stages of reproduction (reproductive; shown in green). The percent of non-reproductive individuals is reported as a negative value. 

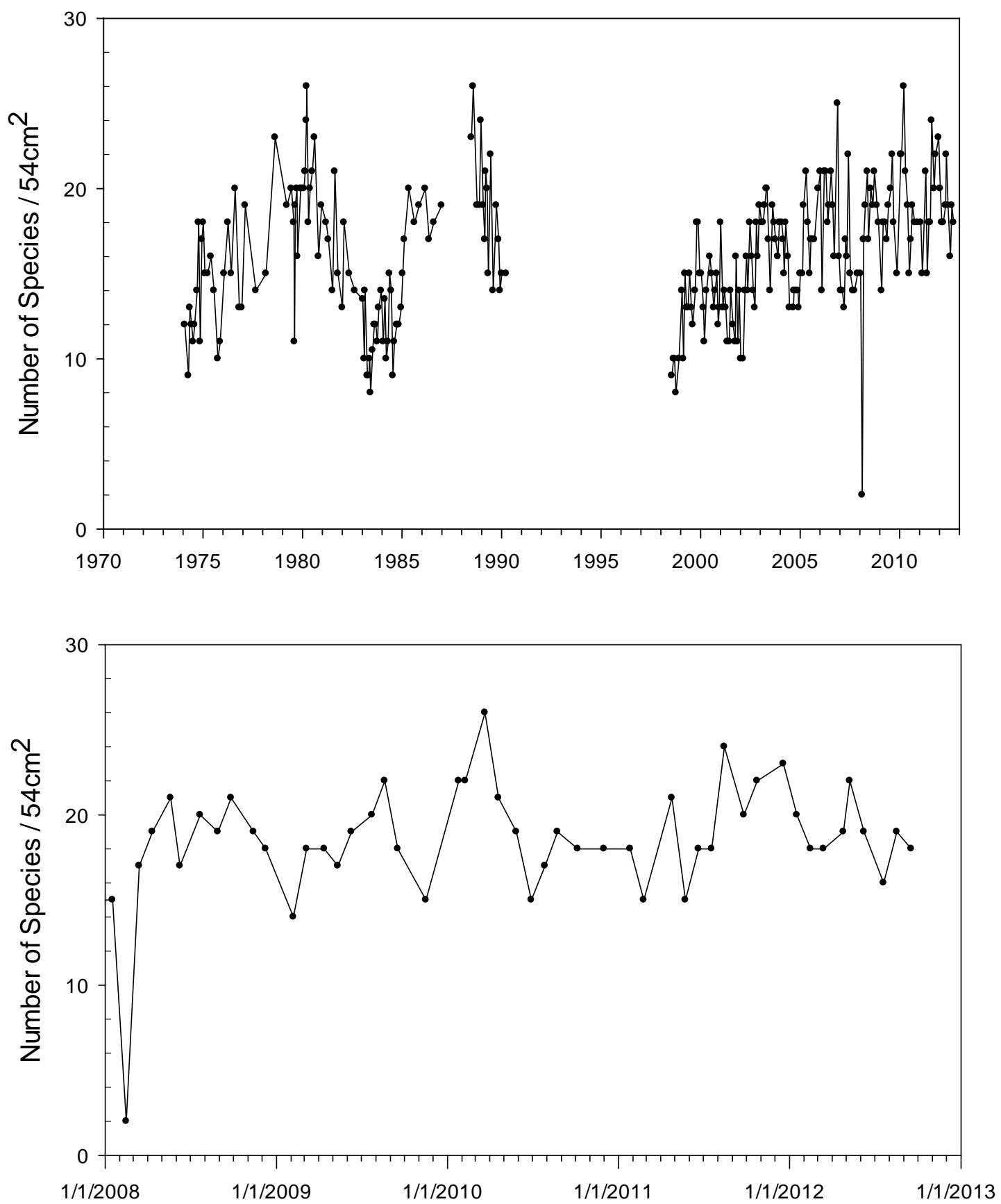

Figure 22. Total number of species present at the Palo Alto site, Calif., 1974-2012. Collections were not made between 1991 and 1998. 

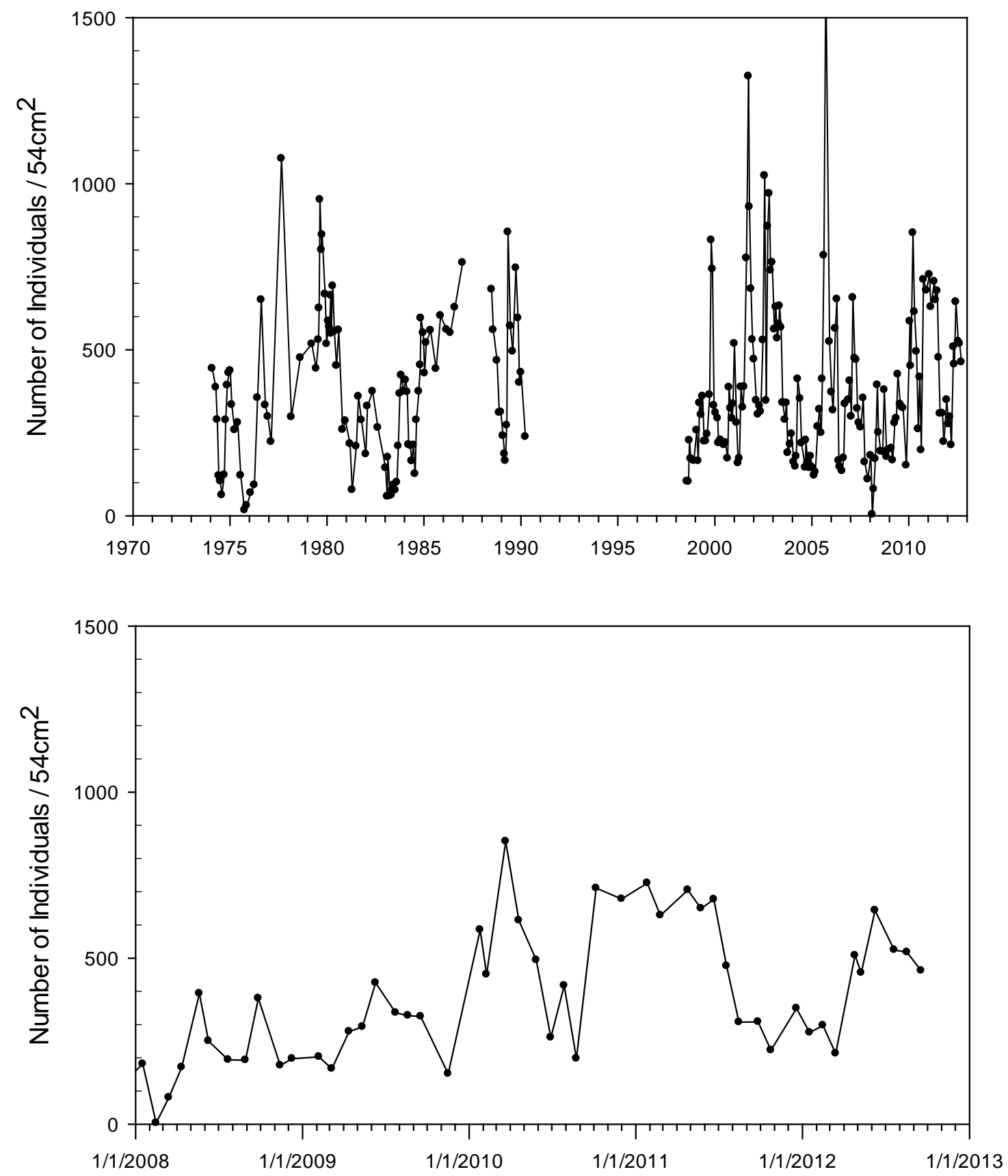

Figure 23. Total average number of individuals present at the Palo Alto site, Calif., 1974-2012. Collections were not made between 1991 and 1998. 

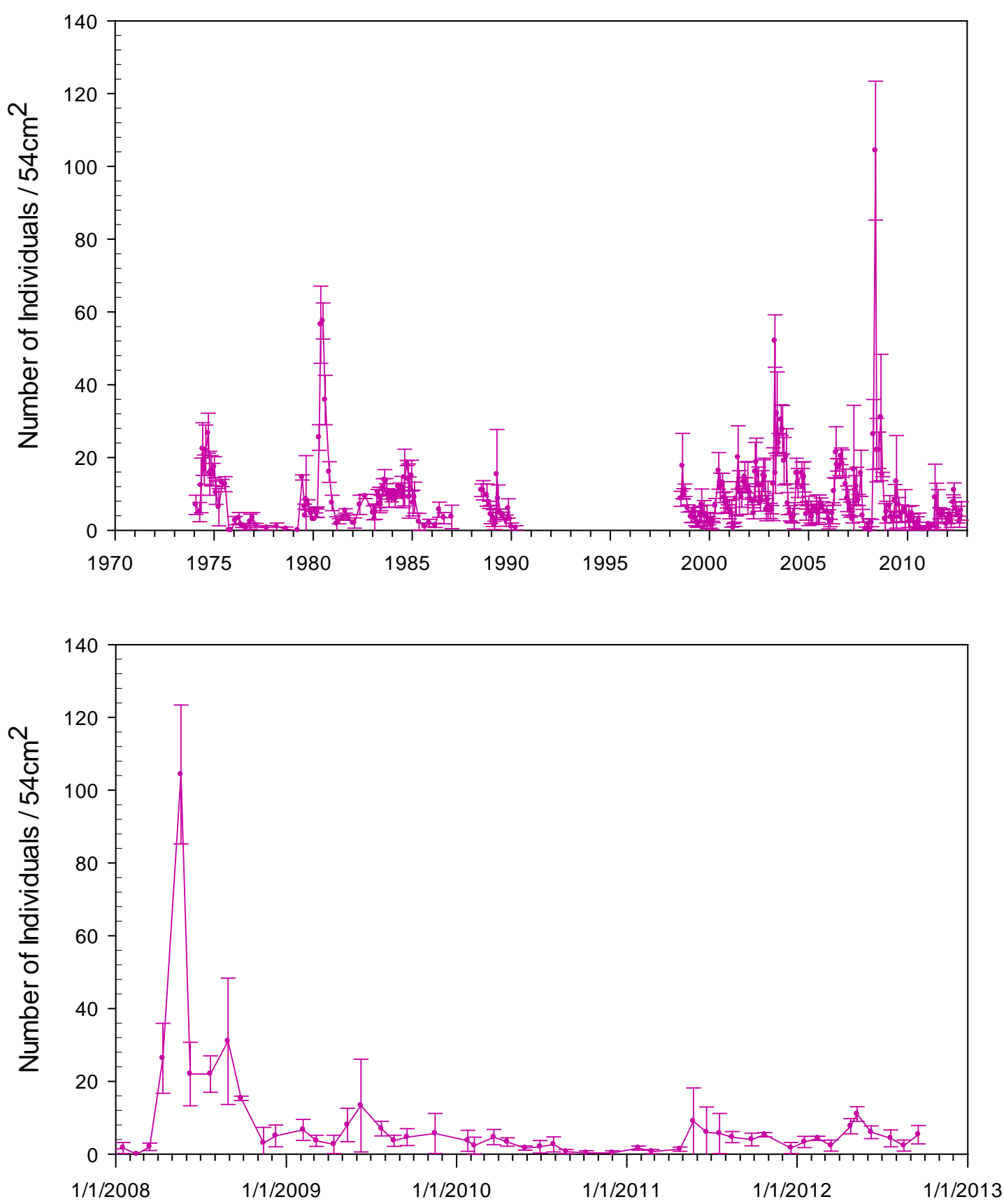

Figure 24. Monthly average abundance of Macoma petalum, Palo Alto, Calif., 1974-2012.Error bars represent standard deviation from three replicate samplings. Collections were not made between 1991 and 1998. 

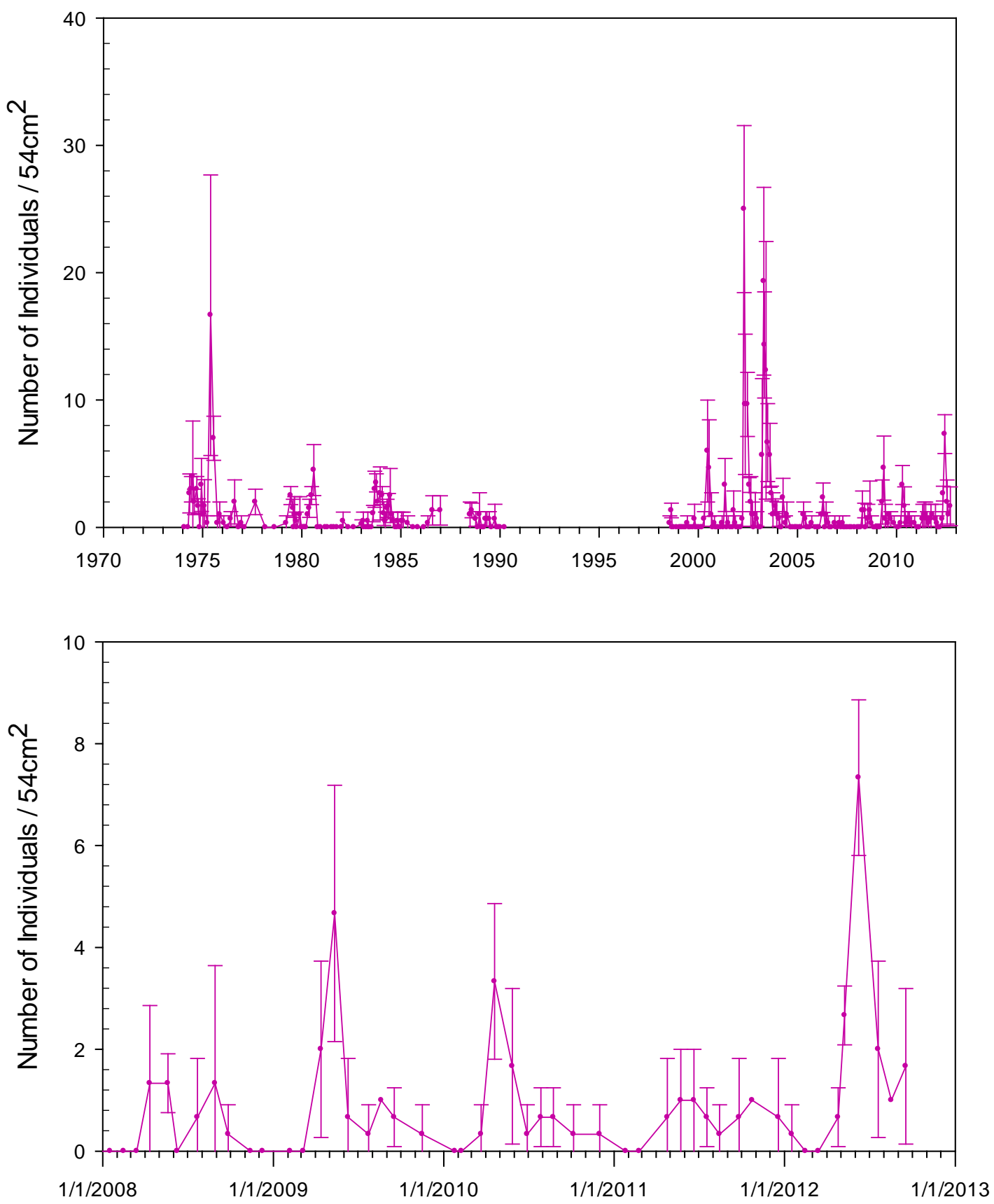

Figure 25. Monthly average abundance of Mya arenaria, Palo Alto, Calif., 1974-2012. Error bars represent standard deviation from three replicate samplings. Collections were not made between 1991 and 1998. 

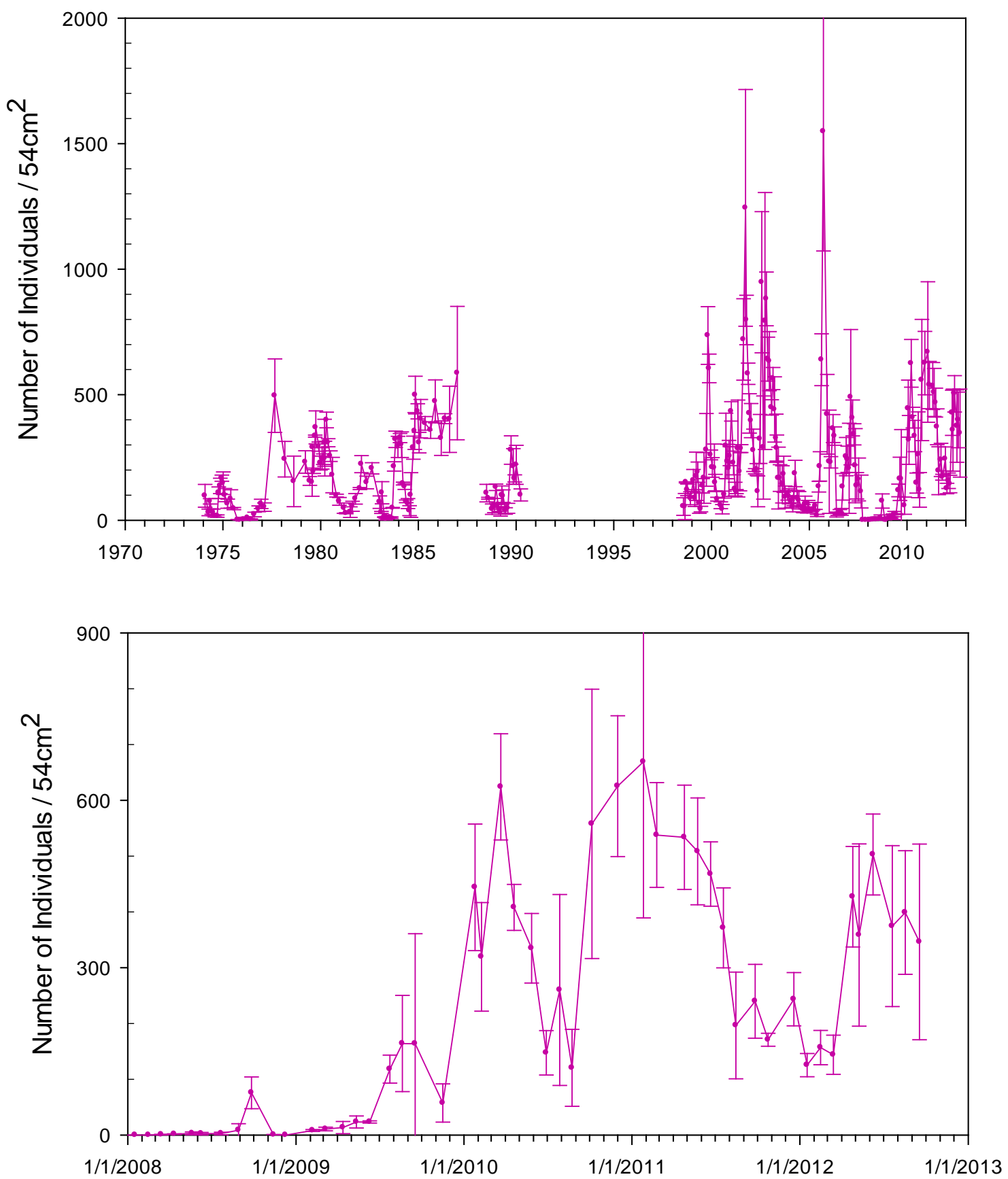

Figure 26. Monthly average abundance of Gemma gemma, Palo Alto, Calif., 1974-2012. Error bars represent standard deviation from three replicate samplings. Collections were not made between 1991 and 1998. 

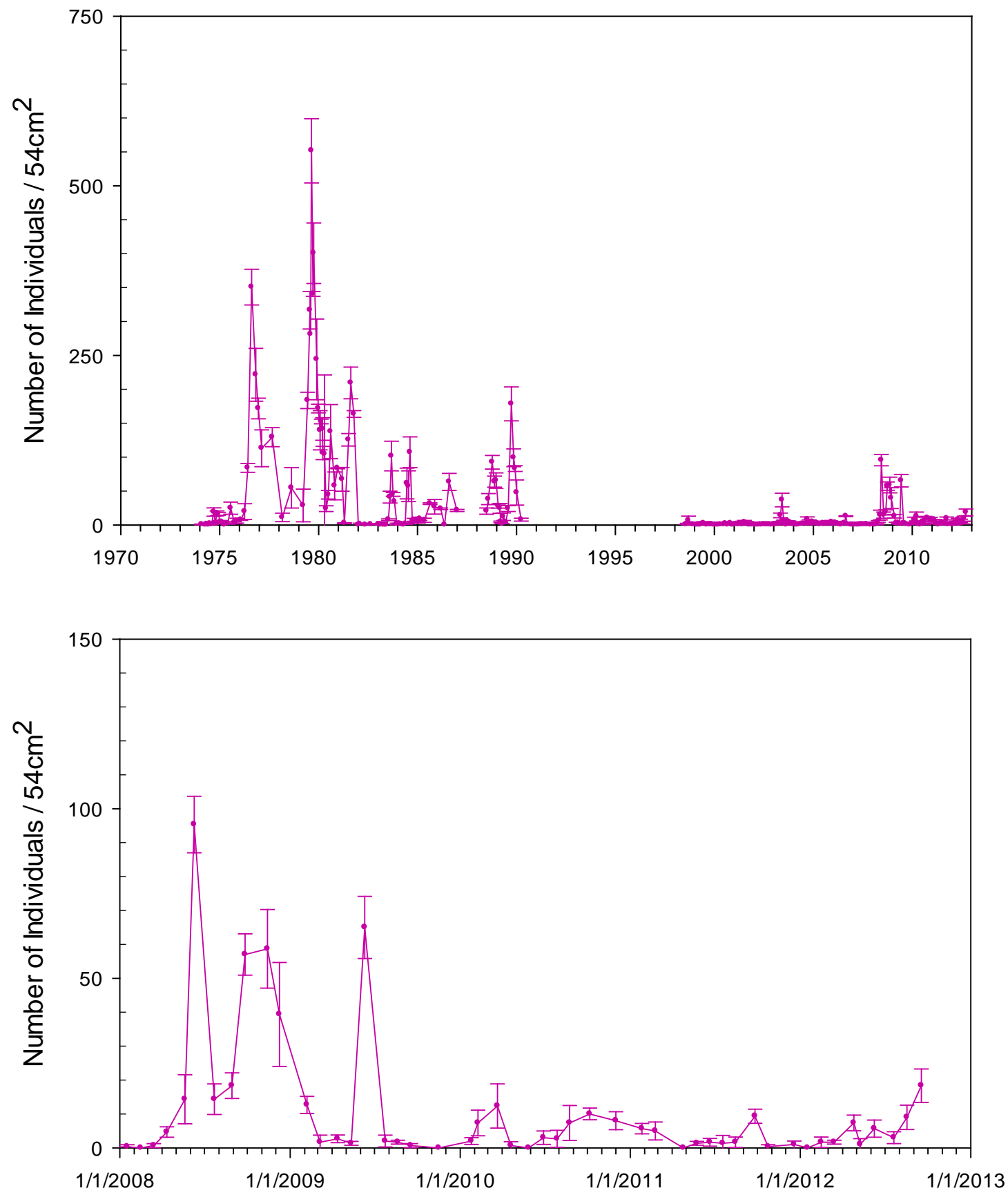

Figure 27. Monthly average abundance of Ampelisca abdita, Palo Alto, Calif., 1974-2012. Error bars represent standard deviation from three replicate samplings. Collections were not made between 1991 and 1998. 

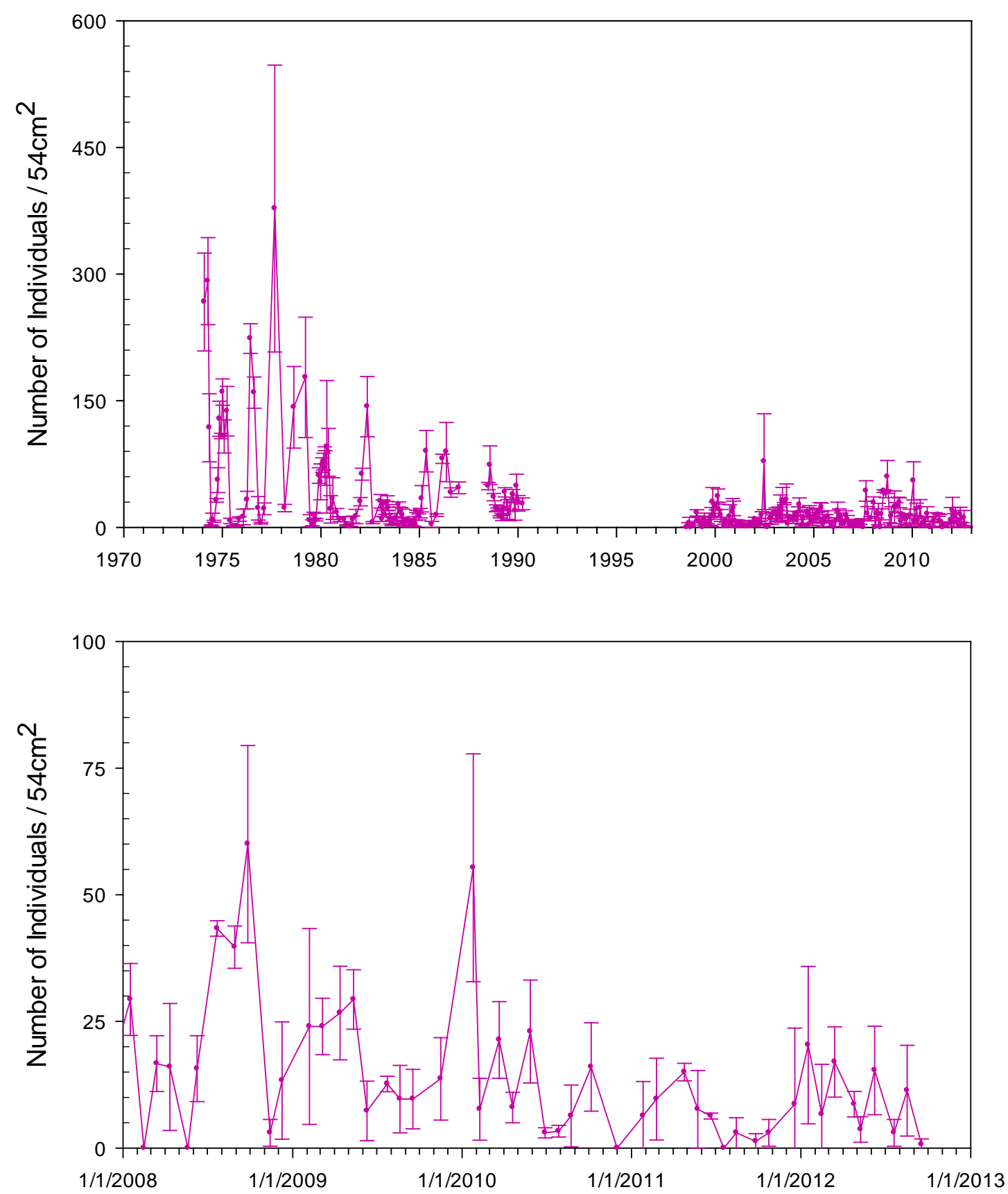

Figure 28. Monthly average abundance of Streblospio benedicti, Palo Alto, Calif., 1974-2012. Error bars represent standard deviation from three replicate samplings. Collections were not made between 1991 and 1998. 

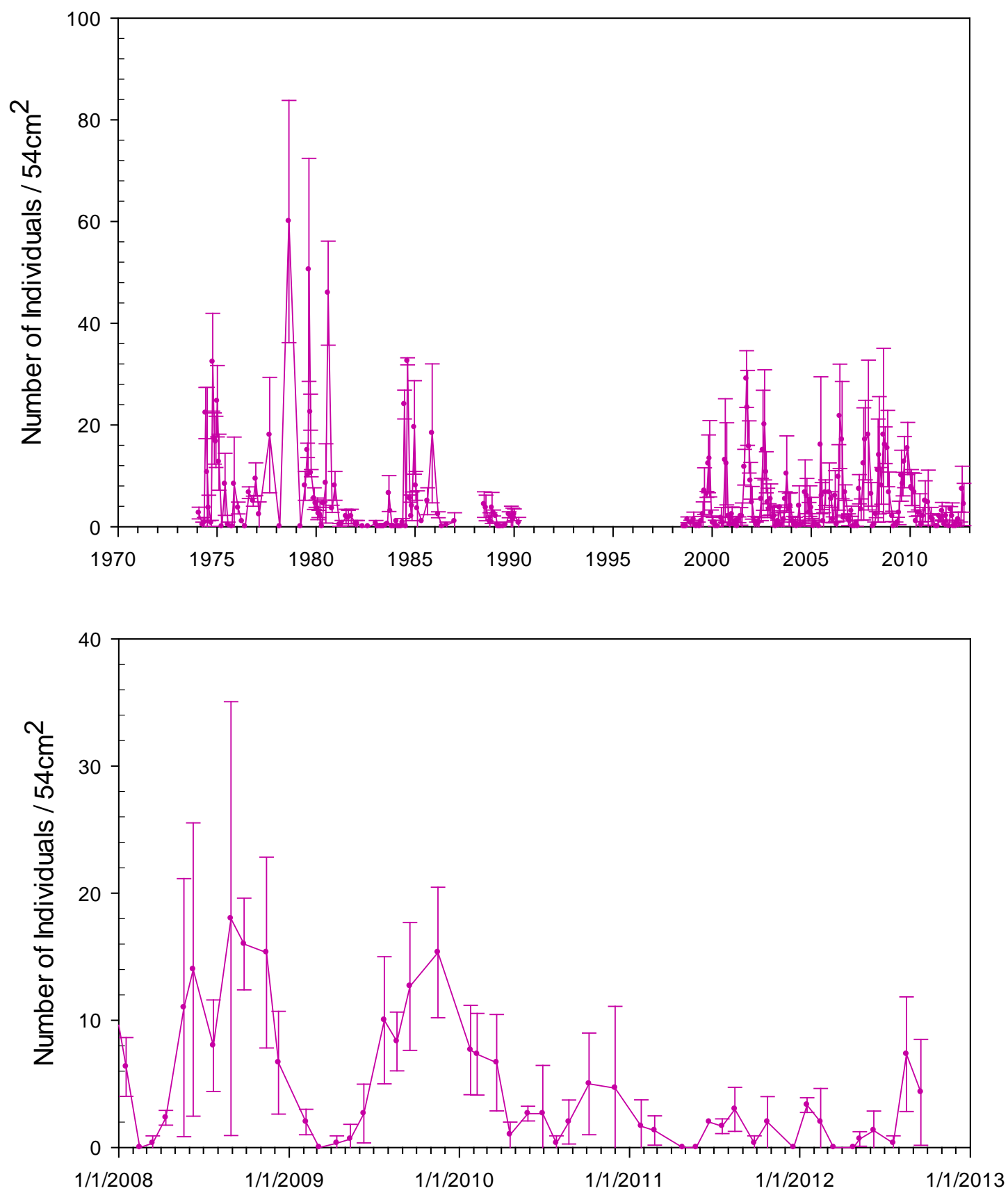

Figure 29. Monthly average abundance of Grandiderella japonica, Palo Alto, Calif., 1974-2012. Error bars represent standard deviation from three replicate samplings. Collections were not made between 1991 and 1998. 

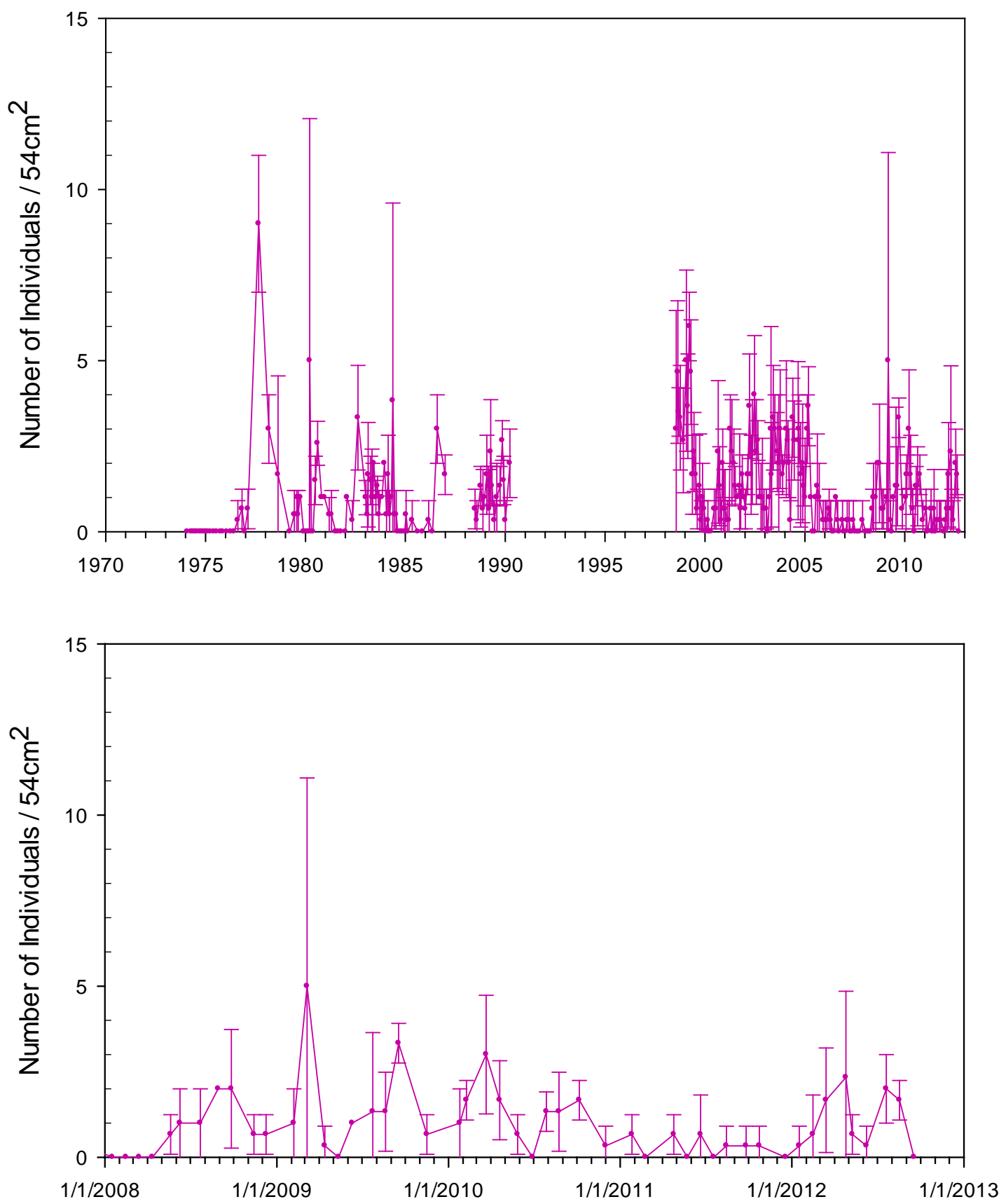

Figure 30. Monthly average abundance of Neanthes succinea, Palo Alto, Calif., 1974-2012. Error bars represent standard deviation from three replicate samplings. Collections were not made between 1991 and 1998. 

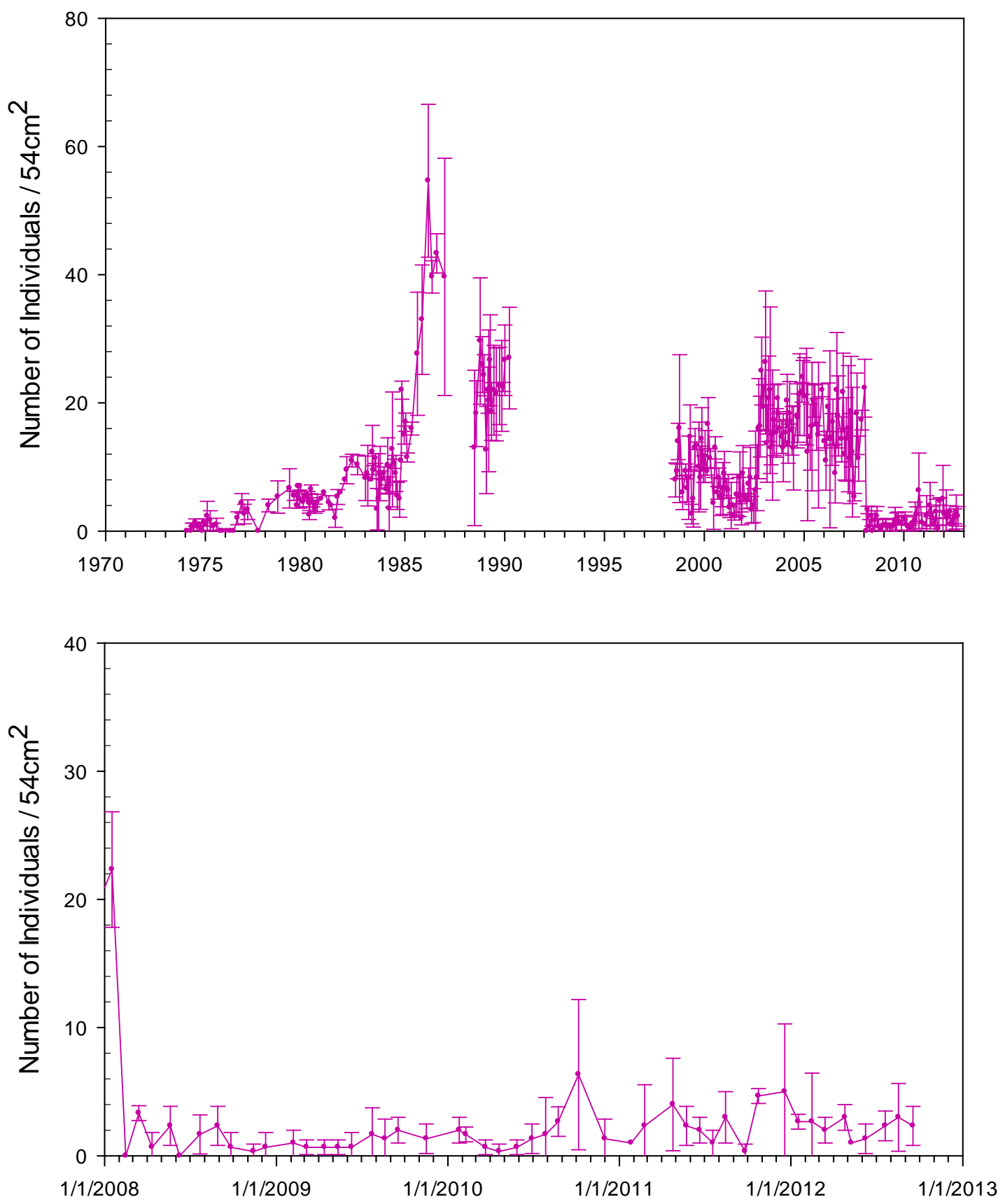

Figure 31. Monthly average abundance of Heteromastus filiformis, Palo Alto, Calif., 1974-2012. Error bars represent standard deviation from three replicate samplings. Collections were not made between 1991 and 1998. 

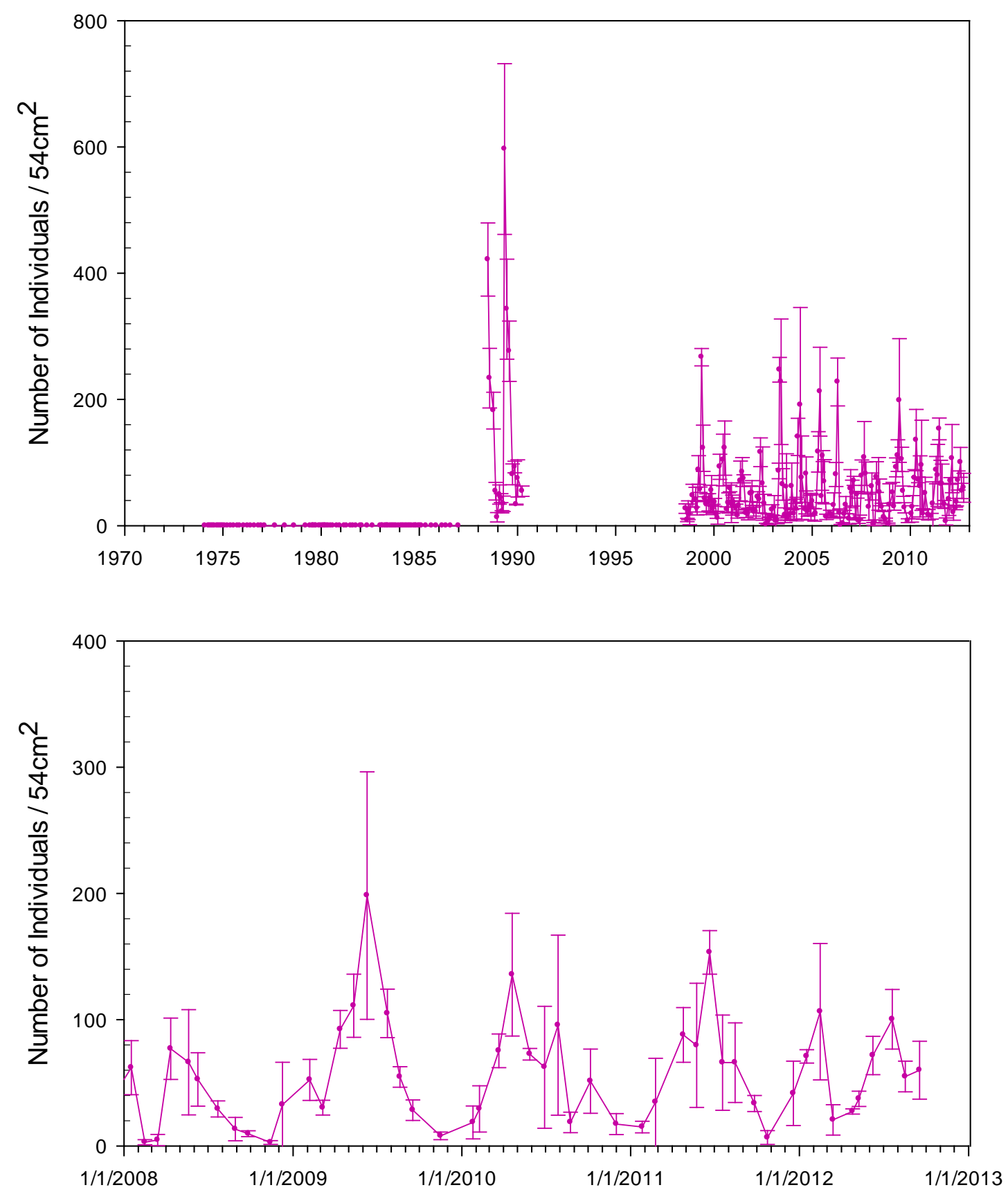

Figure 32. Monthly average abundance of Nippoleucon hinumensis, Palo Alto, Calif., 1974-2012. Error bars represent standard deviation from three replicate samplings. Collections were not made between 1991 and 1998. 


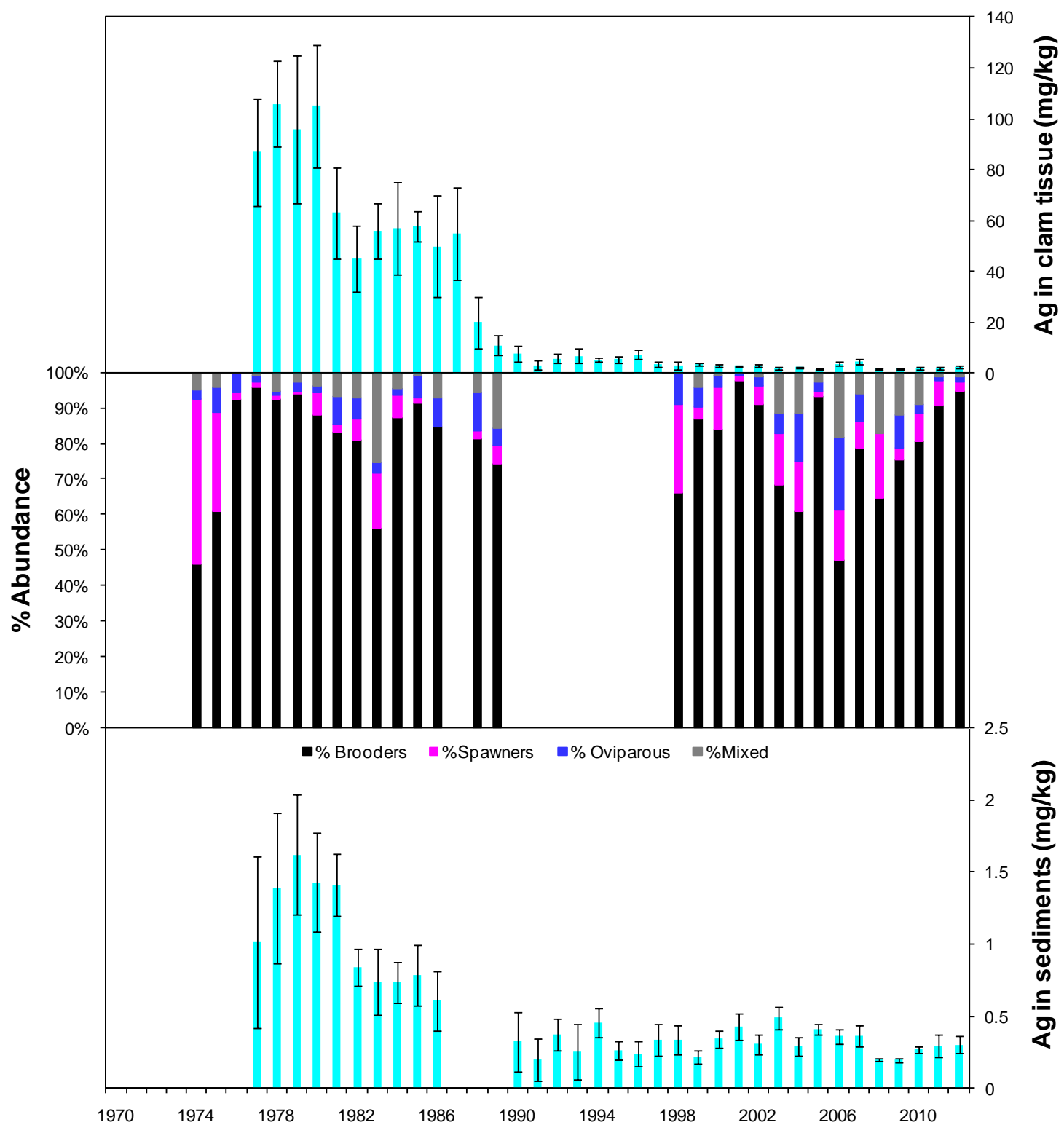

Figure 33. Reproductive mode annual abundance with silver concentrations in the clam Macoma petalum and in sediment, Palo Alto, Calif., 1974-2012.

Annual abundance data is from August of each year. The reproductive mode of the top ten ranked species for each year is shown:

Brooder: broods young and release juveniles as fully functional "miniature adults"; Oviparous: lays eggs in or on sediment;

Spawner: releases gametes into water column and juveniles settle out of plankton onto sediment surface after growth in the plankton. 


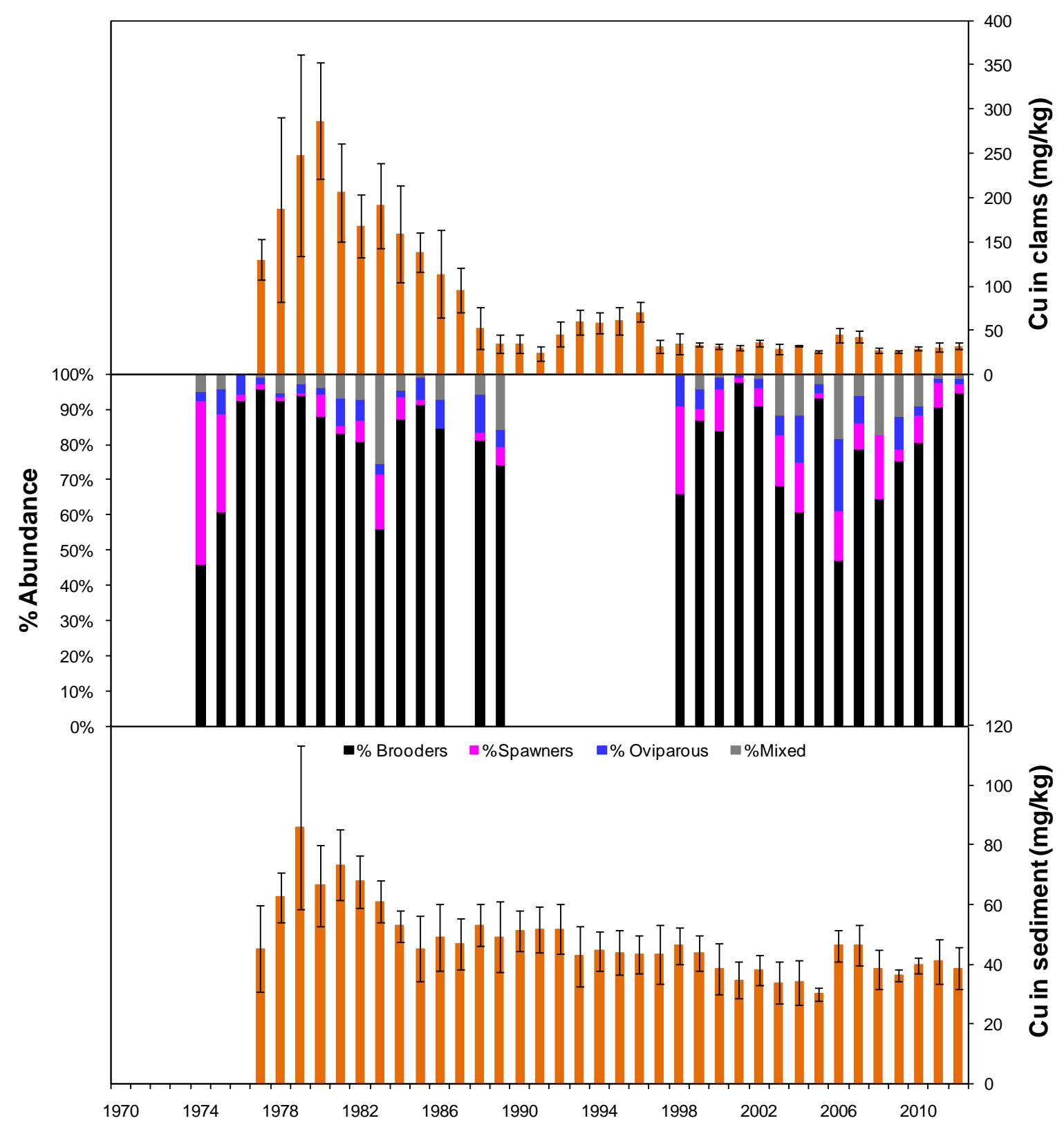

Figure 34. Reproductive mode annual abundance with copper concentrations in the clam Macoma petalum and in sediment, Palo Alto, Calif., 1974-2012.

Annual abundance data is from August of each year. The reproductive mode of the top ten ranked species for each year is shown:

Brooder: broods young and release juveniles as fully functional "miniature adults"; Oviparous: lays eggs in or on sediment;

Spawner: releases gametes into water column and juveniles settle out of plankton onto sediment surface after growth in the plankton. 


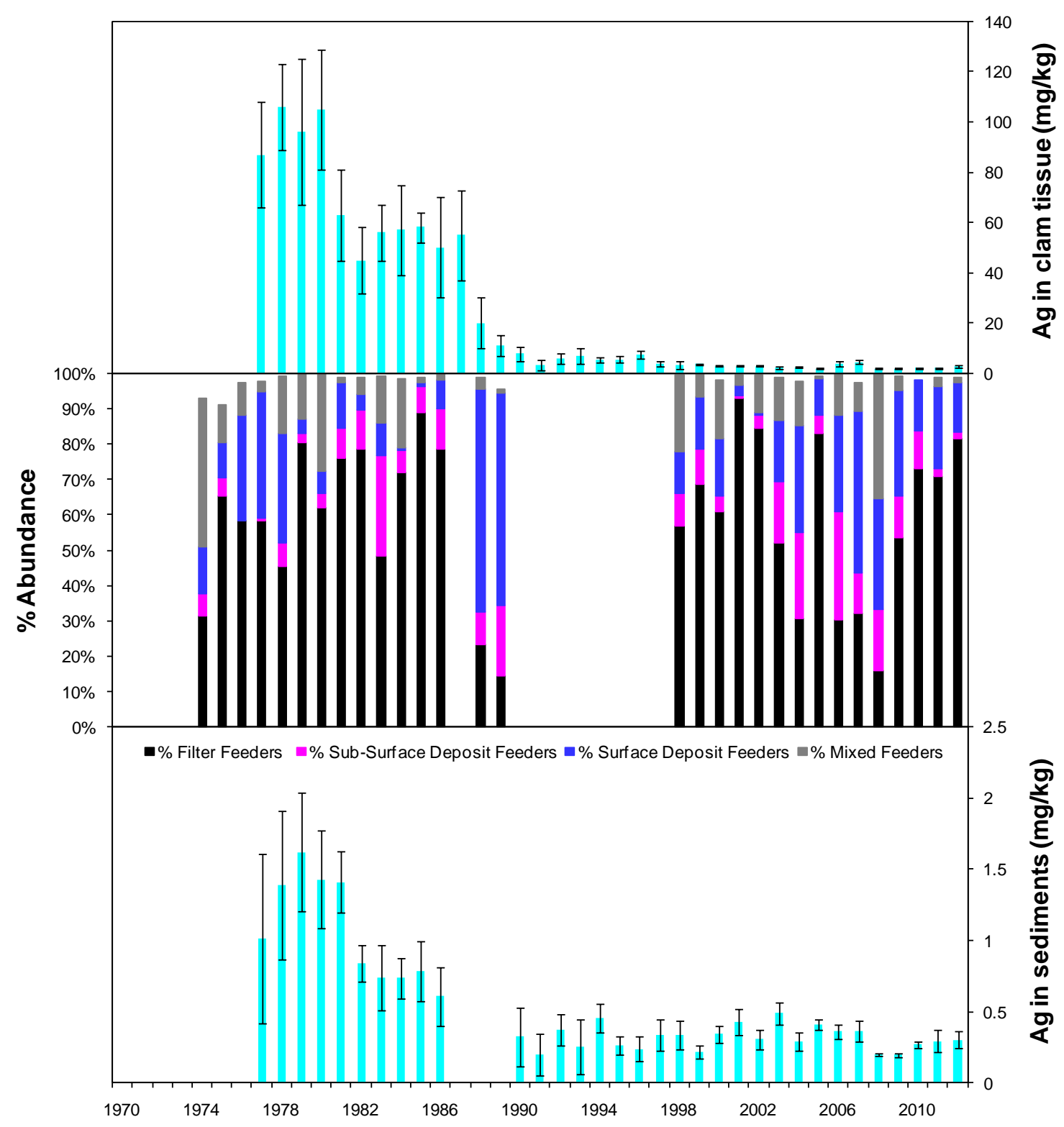

Figure 35. Feeding mode annual abundance with silver concentrations in the clam Macoma petalum and in sediment, Palo Alto, Calif., 1974-2012.

Annual abundance data is from August of each year. The feeding mode of the top ten ranked species for each year is shown:

Filter: filters food particles from water column; Subsurface Deposit: ingests subsurface sediment and removes food from sediment in gut; Surface Deposit: ingests food particles on surface sediment; Mixed: capable of filter feeding and surface deposit feeding; 


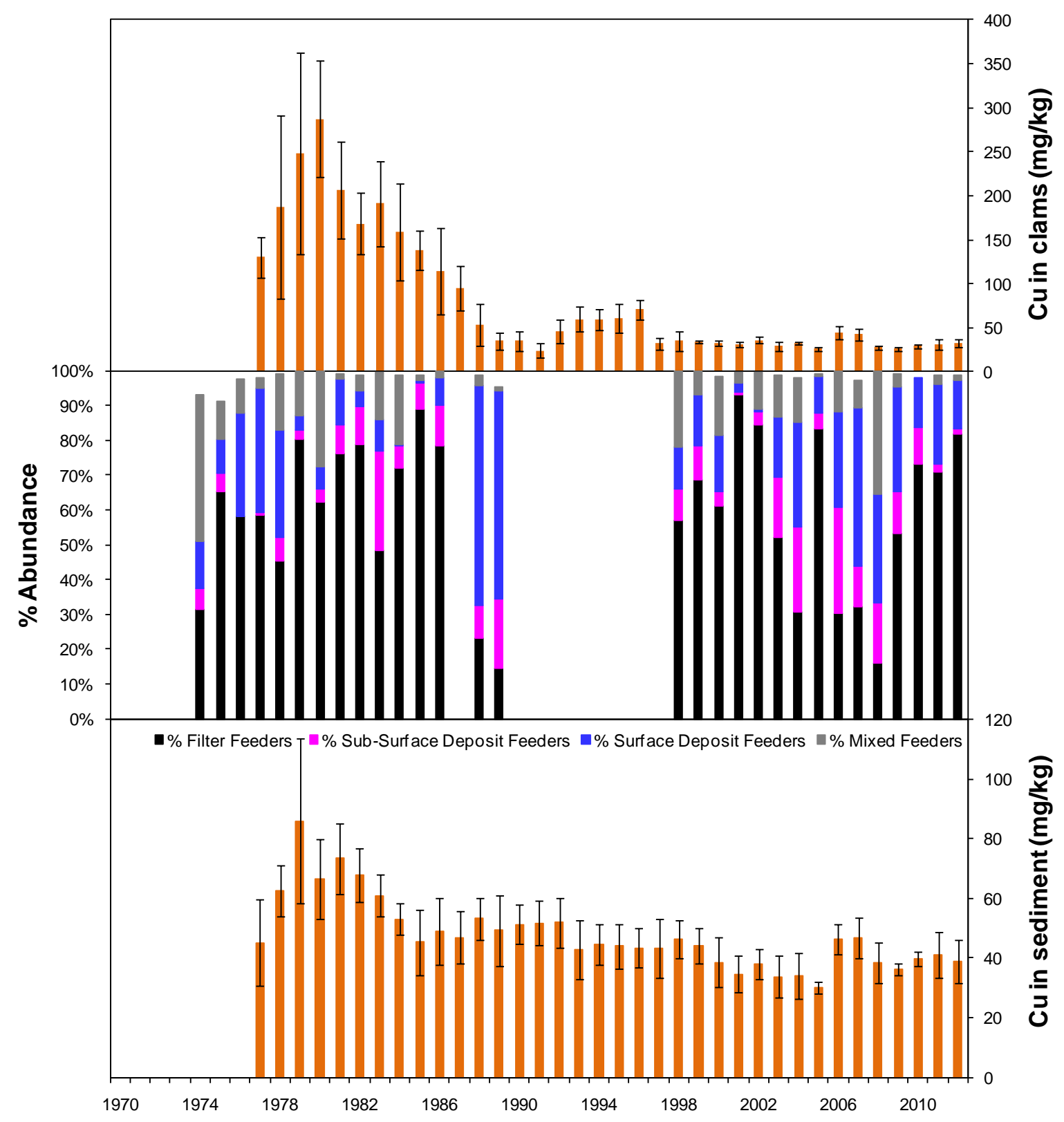

Figure 36. Feeding mode annual abundance with copper concentrations in the clam Macoma petalum and in sediment, Palo Alto, Calif., 1974-2012.

Annual abundance data is from August of each year. The feeding mode of the top ten ranked species for each year is shown:

Filter: filters food particles from water column; Subsurface Deposit: ingests subsurface sediment and removes food from sediment in gut; Surface Deposit: ingests food particles on surface sediment; Mixed: capable of filter feeding and surface deposit feeding; 


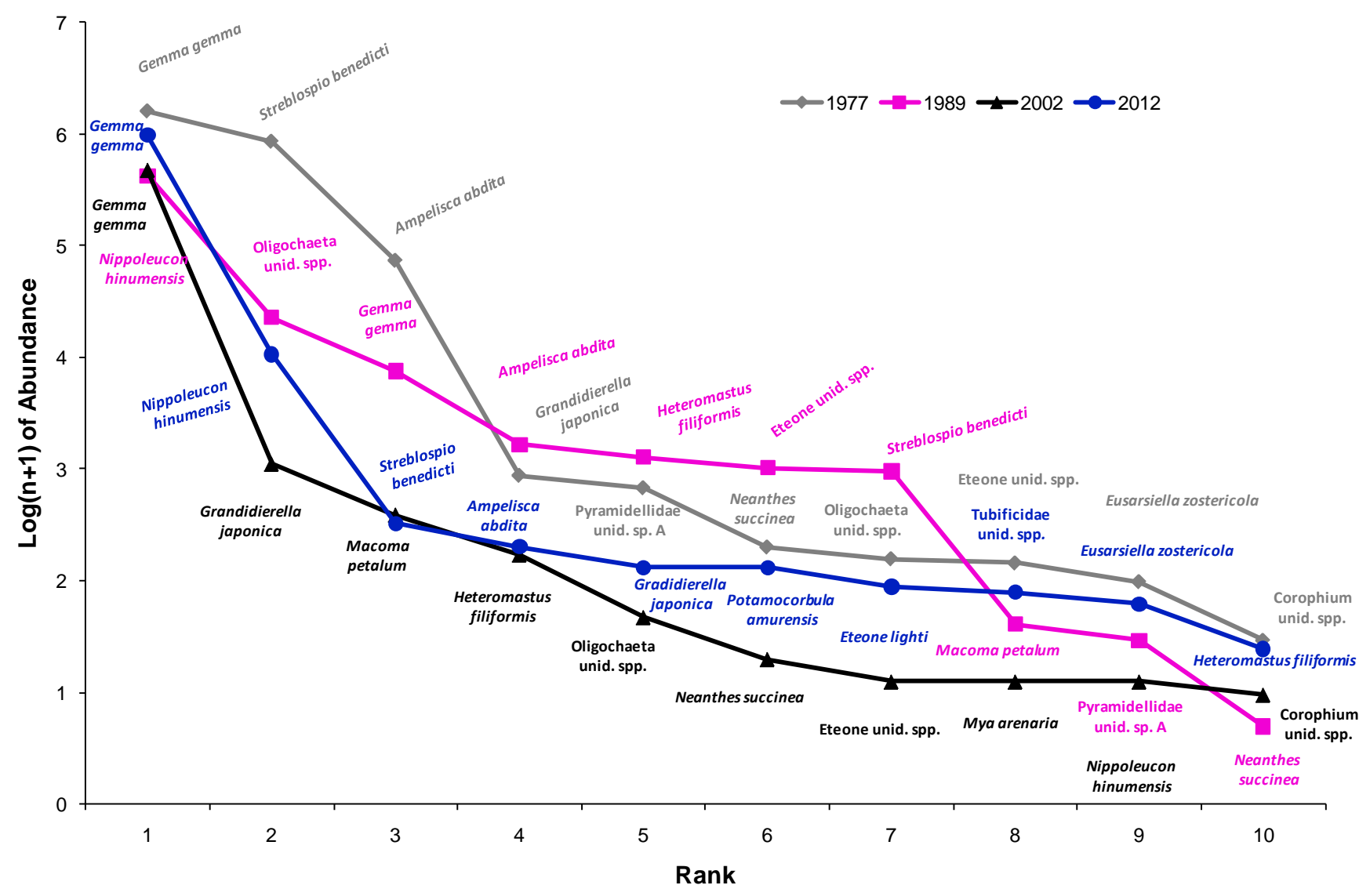

Figure 37. Species rank-abundance for the benthic community, Palo Alto, Calif., 2012. 


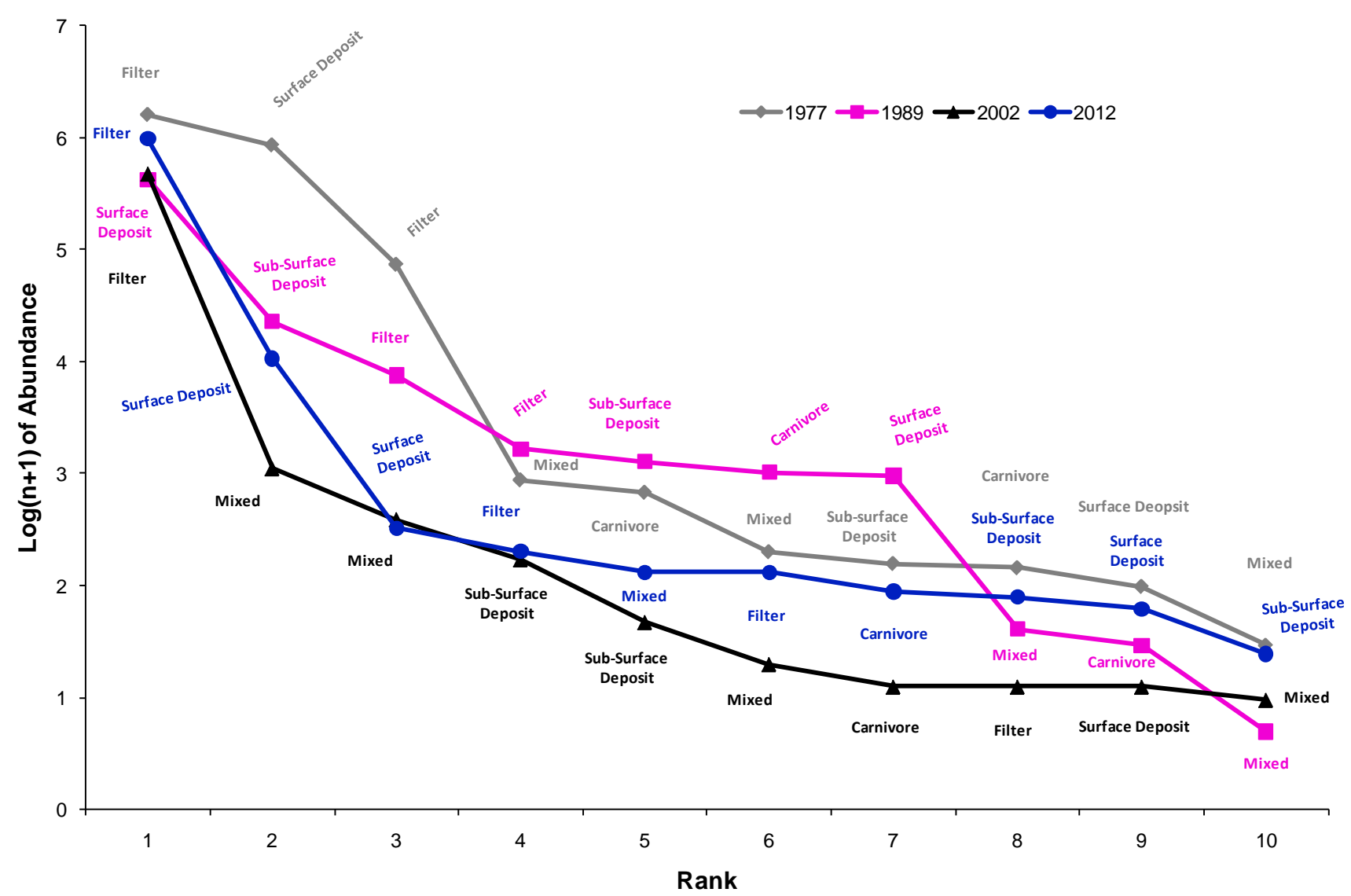

Figure 38. Species rank-abundance identified by feeding mode, Palo Alto, Calif., for 1977, 1989, 2002, and 2012.

The feeding mode for each species at each rank is shown:

Filter: filters food particles from water column; Subsurface Deposit: ingests subsurface sediment and removes food from sediment in gut;

Surface Deposit: ingests food particles on surface sediment; Mixed: capable of filter feeding and surface deposit feeding; Carnivore: predator on other fauna. 


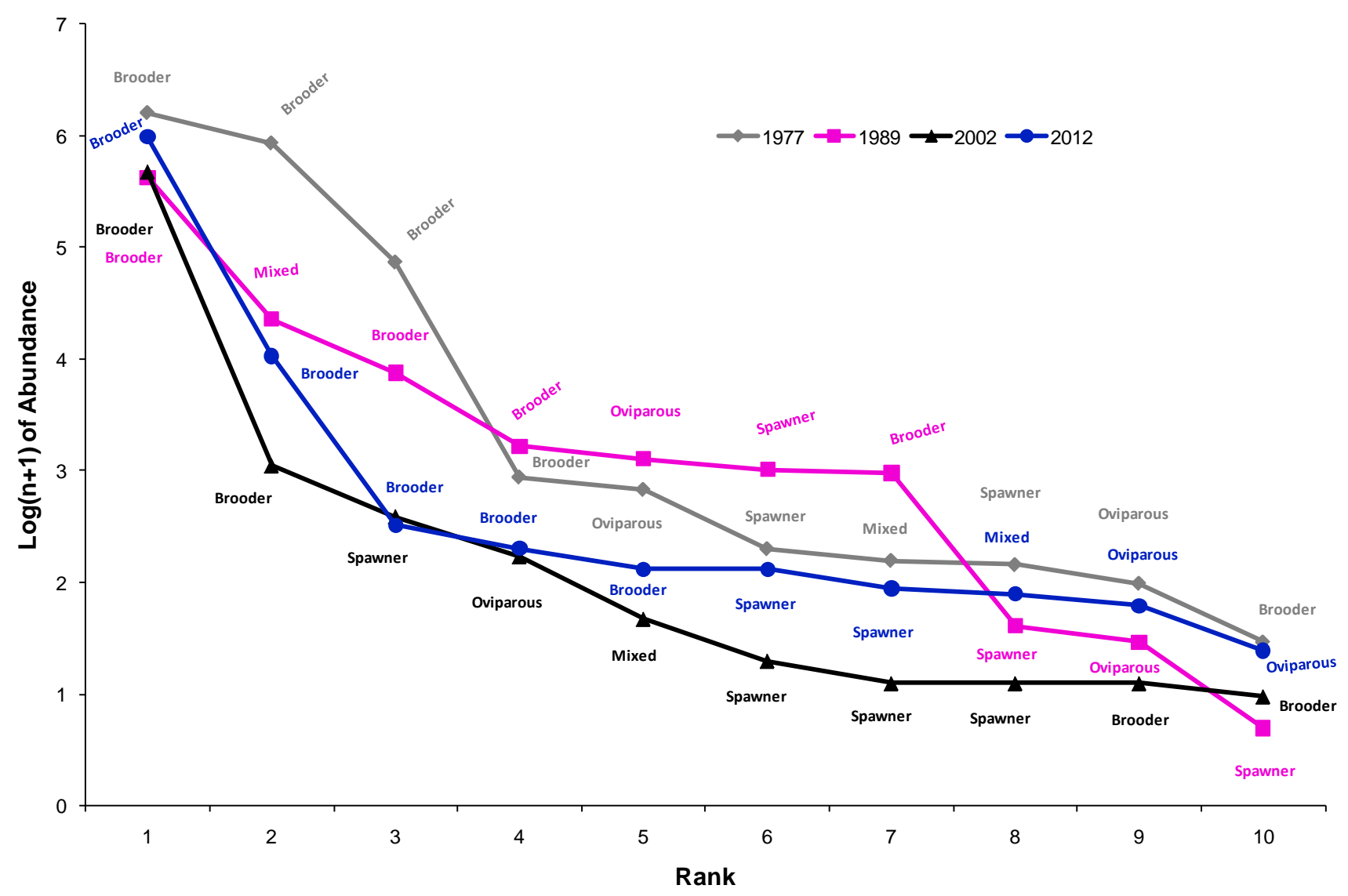

Figure 39. Species rank-abundance data identified by reproductive mode, Palo Alto, Calif., for 1977, 1989, 2002, and 2012.

Reproductive mode for each species at each rank is shown:

Brooder: broods young and release juveniles as fully functional "miniature adults"; Oviparous: lays eggs in or on sediment;

Spawner: releases gametes into water column and juveniles settle out of plankton onto sediment surface after growth in the plankton. 
Table 1. Sediment characteristics, salinity, and concentrations of trace metals in sediments, Palo Alto, Calif., 2012.

[Units for Al, Fe, total organic carbon (TOC), and silt/clay are percent of dry weight. Silt/Clay is operationally determined as $\leq 100$ micrometer grain size. Salinity is reported in units of parts per thousand (ppt) for water pooled at the sediment surface during low tide. Elemental concentrations for the monthly samples are reported as the mean \pm 1 standard deviation (std) for replicate subsamples $(n=2)$. No replicate sample was analyzed for March 2011, therefore there is no standard deviation reported. Units are milligram per kilogram dry weight. Results for TOC, siltclay, and salinity are for a single $(n=1)$ measurement. Means for monthly samples were summarized and reported as the annual mean \pm the standard error (SEM) ( $n=9)$. All concentrations are based on near-total extracts, except for silver (Ag), which is based on partial extraction (see text section on Methods). ND means No Data.]

\begin{tabular}{|c|c|c|c|c|c|c|c|c|c|c|c|c|}
\hline Date & $\mathrm{Ag}$ & $\mathrm{Cr}$ & $\mathrm{Cu}$ & $\mathrm{Hg}$ & $\mathrm{Ni}$ & Se & $\mathrm{Zn}$ & $\mathrm{Al}(\%)$ & $\mathrm{Fe}(\%)$ & $\begin{array}{c}\text { TOC } \\
(\%)\end{array}$ & $\begin{array}{c}\text { Silt/ } \\
\text { Clay } \\
(\%)\end{array}$ & $\begin{array}{c}\text { Salinity } \\
\text { (ppt) }\end{array}$ \\
\hline $1 / 17 / 2012$ & $0.29 \pm 0.003$ & $139 \pm 2$ & $41.7 \pm 0.4$ & 0.27 & $78.9 \pm 1.6$ & 0.31 & $122 \pm 2$ & $5.4 \pm 0.03$ & $4.0 \pm 0.04$ & 1.39 & 82 & 29 \\
\hline 2/14/2012 & $0.37 \pm 0.001$ & $132 \pm 5$ & $44.7 \pm 0.04$ & 0.19 & $78.4 \pm 0.3$ & 0.26 & $127 \pm 0.1$ & $5.4 \pm 0.2$ & $3.9 \pm 0.04$ & 1.39 & 91 & 30 \\
\hline $3 / 26 / 2012$ & $0.33 \pm 0.007$ & $131 \pm 5$ & $46.6 \pm 0.6$ & ND & $74.6 \pm 0.9$ & ND & $120 \pm 2$ & $5.4 \pm 0.2$ & $3.9 \pm 0.1$ & 0.98 & 83 & 26 \\
\hline $4 / 25 / 2012$ & $0.25 \pm 0.004$ & $139 \pm 4$ & $38.6 \pm 1.7$ & 0.27 & $74.1 \pm 0.7$ & 0.31 & $122 \pm 1$ & $5.2 \pm 0.2$ & $4.0 \pm 0.1$ & 1.00 & 83 & 25 \\
\hline $5 / 14 / 2012$ & $0.36 \pm 0.0002$ & $142 \pm 2$ & $48.6 \pm 0.7$ & ND & $81.5 \pm 1.2$ & ND & $143 \pm 6$ & $5.8 \pm 0.1$ & $4.1 \pm 0.003$ & 1.43 & 94 & 22 \\
\hline 6/5/2012 & $0.21 \pm 0.005$ & $113 \pm 1$ & $35.4 \pm 0.01$ & 0.22 & $65.8 \pm 0.3$ & 0.30 & $110 \pm 2$ & $4.1 \pm 0.1$ & $3.4 \pm 0.02$ & 0.94 & 75 & 26 \\
\hline 9/17/2012 & $0.29 \pm 0.0005$ & $95.8 \pm 4$ & $27.8 \pm 1.0$ & 0.22 & $50.8 \pm 0.5$ & 0.20 & $83.3 \pm 2$ & $3.2 \pm 0.1$ & $2.8 \pm 0.03$ & 1.44 & 61 & 29 \\
\hline $10 / 24 / 2012$ & $0.38 \pm 0.009$ & $114 \pm 1$ & $34.7 \pm 0.1$ & $\mathrm{ND}$ & $70.0 \pm 1.7$ & ND & $114 \pm 1$ & $4.1 \pm 0.05$ & $3.6 \pm 0.02$ & 1.06 & 74 & 26 \\
\hline 12/7/2012 & $0.24 \pm 0.001$ & $126 \pm 1$ & $34.7 \pm 0.4$ & 0.17 & $71.6 \pm 2.6$ & 0.41 & $114 \pm 3$ & $4.4 \pm 0.004$ & $3.7 \pm 0.1$ & 1.03 & 58 & 20 \\
\hline Annual Mean: & 0.30 & 126 & 39.2 & 0.22 & 71.8 & 0.30 & 117 & 4.8 & 3.7 & 1.18 & 78 & 26 \\
\hline SEM: & 0.02 & 5 & 2.3 & 0.02 & 3.1 & 0.03 & 5 & 0.3 & 0.1 & 0.07 & 4 & 1 \\
\hline
\end{tabular}


Table 2. Concentrations of trace metals in the clam Macoma petalum, Palo Alto, Calif., 2012.

[Monthly data are the mean and standard deviation for replicate composites $(n=8-13)$. Means for monthly samples were summarized and reported as the annual mean \pm the standard error (SEM) $(n=9)$. All concentrations are based on near-total extracts. Elemental concentrations are milligram per kilogram soft tissue dry weight. The condition index (CI) is the soft tissue weight in milligrams of a clam of 25-millimeter shell length. ND means No Data.]

\begin{tabular}{|c|c|c|c|c|c|c|c|c|}
\hline Date & $\mathrm{Ag}$ & $\mathrm{Cr}$ & $\mathrm{Cu}$ & $\mathrm{Hg}$ & $\mathrm{Ni}$ & Se & $\mathrm{Zn}$ & $\begin{array}{c}\text { Condition } \\
\text { Index }\end{array}$ \\
\hline $1 / 17 / 2012$ & $4.62 \pm 1.46$ & $6.57 \pm 2.59$ & $44.4 \pm 7.9$ & $0.27 \pm 0.05$ & $5.87 \pm 1.76$ & $4.33 \pm 0.48$ & $377 \pm 118$ & 91 \\
\hline $2 / 14 / 2012$ & $3.92 \pm 0.44$ & $3.88 \pm 0.57$ & $42.3 \pm 6.1$ & $0.24 \pm 0.02$ & $4.15 \pm 0.50$ & $4.26 \pm 0.01$ & $316 \pm 22$ & 101 \\
\hline $3 / 26 / 2012$ & $1.80 \pm 0.75$ & $3.03 \pm 0.61$ & $23.8 \pm 5.2$ & ND & $3.73 \pm 0.62$ & ND & $239 \pm 46$ & 156 \\
\hline $4 / 25 / 2012$ & $1.28 \pm 0.78$ & $1.91 \pm 0.55$ & $29.1 \pm 22.1$ & $0.19 \pm 0.01$ & $3.57 \pm 0.93$ & $3.67 \pm 0.18$ & $250 \pm 52$ & 140 \\
\hline $5 / 14 / 2012$ & $0.838 \pm 0.515$ & $1.22 \pm 0.68$ & $15.5 \pm 2.6$ & ND & $2.64 \pm 0.56$ & ND & $193 \pm 36$ & 188 \\
\hline $6 / 5 / 2012$ & $0.952 \pm 0.818$ & $1.39 \pm 0.45$ & $17.1 \pm 3.9$ & $0.18 \pm 0.18$ & $2.87 \pm 0.65$ & $2.97 \pm 0.17$ & $185 \pm 45$ & 184 \\
\hline $9 / 17 / 2012$ & $2.71 \pm 1.14$ & $1.72 \pm 0.54$ & $38.7 \pm 8.2$ & $0.30 \pm 0.30$ & $3.80 \pm 1.00$ & $3.79 \pm 0.69$ & $218 \pm 31$ & 121 \\
\hline $10 / 24 / 2012$ & $3.62 \pm 1.00$ & $2.09 \pm 0.79$ & $43.7 \pm 9.2$ & ND & $4.37 \pm 1.05$ & ND & $251 \pm 106$ & 105 \\
\hline $12 / 7 / 2012$ & $3.88 \pm 1.08$ & $1.50 \pm 0.57$ & $38.9 \pm 8.4$ & $0.31 \pm 0.313$ & $3.58 \pm 0.85$ & $3.68 \pm 0.49$ & $231 \pm 42$ & 106 \\
\hline Annual Mean: & 2.62 & 2.59 & 32.6 & 0.25 & 3.84 & 3.78 & 251 & 132 \\
\hline SEM: & 0.48 & 0.57 & 3.8 & 0.02 & 0.31 & 0.20 & 20 & 12 \\
\hline
\end{tabular}


Table 3. Reproduction data for Macoma petalum, Palo Alto, Calif., 2012.

[Data are percentage of clams in each stage of reproduction. Reproductive = the percentage of clams in Active, Ripe, and Spawning stages. Non-Reproductive $=$ the percentage of clams in Inactive and Spent stages. Spent means the clams have released all their gametes.

$\mathrm{N}$ refers to the number of clams that were analyzed. ND means No Data.]

\begin{tabular}{c|c|c|c|c|c|c|cc|c}
\hline Date & Inactive & Active & Ripe & Spawning & Spent & N & $\begin{array}{c}\text { Non- } \\
\text { Reproductive Reproductive }\end{array}$ \\
\hline \begin{tabular}{|c|c|c|c|c|c|c|c|}
$1 / 16 / 2012$ \\
$2 / 14 / 2012$
\end{tabular} & 0 & 30 & 70 & 0 & 0 & 10 & 100 & 0 \\
$3 / 26 / 2012$ & 0 & 0 & 100 & 0 & 0 & 10 & 100 & 0 \\
$4 / 25 / 2012$ & 0 & 0 & 80 & 20 & 0 & 10 & 100 & 0 \\
$5 / 14 / 2012$ & 0 & 0 & 40 & 0 & 60 & 10 & 40 & -60 \\
$6 / 5 / 2012$ & 0 & 0 & 0 & 40 & 60 & 10 & 40 & -60 \\
$10 / 24 / 2012$ & 0 & 100 & 0 & 0 & 0 & 10 & 100 & -90 \\
$12 / 7 / 2012$ & 0 & 40 & 60 & 0 & 0 & 10 & 100 & 0 \\
\hline
\end{tabular}


Appendixes 1-11 
Appendix 1. Statistical summary of percentage of sediment in samples composed of clay-and silt-sized particles, collected from Palo Alto, Calif., 1994-2012.

[Statistical results are for percent fine-grained particles (silt and clay, $\leq 100$ micrometer) observed each month from 1994-2011. Data for percent fines for 2004, which contain unquantifiable biases due to errors in sample processing, are not included in these statistical calculations. \# of samples refers to the number of times data were collected in that respective month during the span of collection years.]

\begin{tabular}{lccccc}
\hline Month & \# of samples & Maximum & Minimum & Mean & Median \\
\hline January & 17 & 96 & 46 & 74 & 75 \\
February & 17 & 98 & 32 & 81 & 87 \\
March & 17 & 98 & 24 & 79 & 84 \\
April & 17 & 96 & 50 & 84 & 86 \\
May & 12 & 95 & 35 & 75 & 80 \\
June & 17 & 95 & 56 & 73 & 70 \\
July & 1 & - & - & - & 69 \\
August & 1 & - & - & - & 48 \\
September & 17 & 84 & 25 & 56 & 56 \\
October & 13 & 84 & 39 & 62 & 59 \\
November & 3 & 66 & 50 & 59 & 61 \\
December & 17 & 95 & 48 & 73 & 72 \\
\hline
\end{tabular}


Appendix 2. Trace-metal concentrations in sediment samples collected at the Palo Alto, Calif., mudflat, 2012.

[For each collection, replicate subsamples were digested in nitric acid (near-total metal extraction) and in dilute hydrochloric acid (partial metal extraction). The dry weight, reconstitution volume, and dilution factor (if applicable) are shown for each replicate and extraction method. Concentrations are reported for sample solutions (in micrograms per milliliter, $\mu \mathrm{g} / \mathrm{mL}$ ) and the calculated weight-standardized concentration (reported as milligram per kilogram dry sediment, $\mathrm{mg} / \mathrm{kg}$ ). The sample mean and standard deviation for the weightstandardized concentration are also reported.] 
Near-total metal extractions

\begin{tabular}{|c|c|c|c|c|c|c|c|c|c|c|c|c|}
\hline \multicolumn{4}{|c|}{ 1/17/2012: $82.2 \%<100 \mu \mathrm{m}$} & \multicolumn{9}{|c|}{ Concentration, $\mu \mathrm{g} / \mathrm{mL}$} \\
\hline Sample & Weight (g) & Recon. $(\mathrm{mL})$ & Dil. Factor & $\mathrm{Al}$ & $\mathrm{Cr}$ & $\mathrm{Cu}$ & $\mathrm{Fe}$ & $\mathrm{Mn}$ & $\mathrm{Ni}$ & $\mathrm{Pb}$ & $\mathrm{V}$ & $\mathrm{Zn}$ \\
\hline Tot1 & 0.5107 & 10 & 10 & 277 & 0.716 & 0.212 & 206 & 4.94 & 0.409 & 0.0987 & 0.505 & 0.628 \\
\hline \multirow[t]{2}{*}{ Tot2 } & 0.5140 & 10 & 10 & 276 & 0.705 & 0.216 & 204 & 4.94 & 0.400 & 0.0945 & 0.499 & 0.619 \\
\hline & & & & \multicolumn{9}{|c|}{ Concentration, $\mathrm{mg} / \mathrm{kg}$} \\
\hline Tot1 & & & & 54,141 & 140 & 41.4 & 40,396 & 967 & 80.0 & 19.3 & 99 & 123 \\
\hline \multirow[t]{3}{*}{ Tot2 } & & & & 53,696 & 137 & 42.0 & 39,767 & 960 & 77.8 & 18.4 & 97 & 120 \\
\hline & & & Average & 53,919 & 139 & 41.7 & 40,081 & 964 & 78.9 & 18.9 & 98 & 122 \\
\hline & & & Std & 315 & 2 & 0.4 & 445 & 5 & 1.6 & 0.7 & 1 & 2 \\
\hline
\end{tabular}

\begin{tabular}{|c|c|c|c|c|c|c|c|c|c|c|c|c|}
\hline \multicolumn{4}{|c|}{ 2/14/2012: $91.3 \%<100 \mu \mathrm{m}$} & \multicolumn{9}{|c|}{ Concentration, $\mu \mathrm{g} / \mathrm{mL}$} \\
\hline Sample & Weight (g) & Recon. $(\mathrm{mL})$ & Dil. Factor & $\mathrm{Al}$ & $\mathrm{Cr}$ & $\mathrm{Cu}$ & $\mathrm{Fe}$ & $\mathrm{Mn}$ & $\mathrm{Ni}$ & $\mathrm{Pb}$ & $\mathrm{V}$ & $\mathrm{Zn}$ \\
\hline Tot1 & 0.5644 & 10 & 10 & 294 & 0.724 & 0.253 & 220 & 6.59 & 0.441 & 0.1137 & 0.495 & 0.715 \\
\hline \multirow[t]{2}{*}{ Tot2 } & 0.5232 & 10 & 10 & 290 & 0.710 & 0.234 & 208 & 6.18 & 0.412 & 0.1090 & 0.504 & 0.663 \\
\hline & & & & \multicolumn{9}{|c|}{ Concentration, $\mathrm{mg} / \mathrm{kg}$} \\
\hline Tot1 & & & & 52,038 & 128 & 44.7 & 39,033 & 1,167 & 78.2 & 20.1 & 88 & 127 \\
\hline \multirow[t]{3}{*}{ Tot2 } & & & & 55,447 & 136 & 44.7 & 39,660 & 1,181 & 78.7 & 20.8 & 96 & 127 \\
\hline & & & Average & 53,742 & 132 & 44.7 & 39,346 & 1,174 & 78.4 & 20.5 & 92 & 127 \\
\hline & & & Std & 2,411 & 5 & 0.04 & 443 & 10 & 0.3 & 0.5 & 6 & 0.1 \\
\hline
\end{tabular}

\section{3/26/2012: 82.5\% <100 $\mu \mathrm{m}$}

Sample Weight $(\mathrm{g})$ Recon. $(\mathrm{mL})$ Dil. Factor

\begin{tabular}{llll}
\hline Tot1 & 0.5257 & 10 & 10 \\
& 0.5189 & 10 & 10
\end{tabular}

10
10

Tot1

Tot2

\begin{tabular}{lccccccccc} 
& \multicolumn{10}{c}{ Concentration, $\mathrm{mg} / \mathrm{kg}$} \\
\cline { 2 - 10 } & 52,692 & 127 & 46.2 & 38,121 & 1,063 & 74.0 & 18.6 & 92 & 119 \\
& 55,040 & 135 & 47.0 & 39,083 & 1,094 & 75.3 & 19.1 & 94 & 121 \\
\hline Average & 53,866 & 131 & 46.6 & 38,602 & 1,078 & 74.6 & 18.9 & 93 & 120 \\
Std & 1,660 & 5 & 0.6 & 680 & 22 & 0.9 & 0.4 & 2 & 2 \\
\hline
\end{tabular}

Concentration, $\mu \mathrm{g} / \mathrm{mL}$

\begin{tabular}{ccccccccc}
$\mathrm{Al}$ & $\mathrm{Cr}$ & $\mathrm{Cu}$ & $\mathrm{Fe}$ & $\mathrm{Mn}$ & $\mathrm{Ni}$ & $\mathrm{Pb}$ & $\mathrm{V}$ & $\mathrm{Zn}$ \\
\hline 277 & 0.668 & 0.243 & 200 & 5.59 & 0.389 & 0.098 & 0.483 & 0.625 \\
286 & 0.699 & 0.244 & 203 & 5.68 & 0.391 & 0.099 & 0.489 & 0.628
\end{tabular}

Concentration, $\mathrm{mg} / \mathrm{kg}$ 
Near-total metal extractions, continued

\begin{tabular}{|c|c|c|c|c|c|c|c|c|c|c|c|c|}
\hline \multicolumn{4}{|c|}{ 4/25/2012: $82.9 \%<100 \mu \mathrm{m}$} & \multicolumn{9}{|c|}{ Concentration, $\mu \mathrm{g} / \mathrm{mL}$} \\
\hline Sample & Weight (g) & Recon. (mL) & Dil. Factor & A & $\mathrm{Cr}$ & $\mathrm{Cu}$ & $\mathrm{Fe}$ & $\mathrm{Mn}$ & $\mathrm{Ni}$ & $\mathrm{Pb}$ & V & $\mathrm{Zn}$ \\
\hline Tot1 & 0.5271 & 10 & 10 & 282 & 0.750 & 0.210 & 213 & 5.09 & 0.393 & 0.0926 & 0.537 & 0.650 \\
\hline \multirow[t]{2}{*}{ Tot2 } & 0.5146 & 10 & 10 & 262 & 0.701 & 0.192 & 200 & 4.73 & 0.379 & 0.0911 & 0.508 & 0.624 \\
\hline & & & & \multicolumn{9}{|c|}{ Concentration, $\mathrm{mg} / \mathrm{kg}$} \\
\hline Tot1 & & & & 53,481 & 142 & 39.8 & 40,467 & 966 & 74.5 & 17.6 & 102 & 123 \\
\hline \multirow[t]{3}{*}{ Tot2 } & & & & 50,913 & 136 & 37.4 & 38,904 & 919 & 73.6 & 17.7 & 99 & 121 \\
\hline & & & Average & 52,197 & 139 & 38.6 & 39,685 & 943 & 74.1 & 17.6 & 100 & 122 \\
\hline & & & Std & 1,816 & 4 & 1.7 & 1,105 & 33 & 0.7 & 0.1 & 2 & 1 \\
\hline
\end{tabular}

5/14/2012: $94.4 \%<100 \mu \mathrm{m}$

Concentration, $\mu \mathrm{g} / \mathrm{mL}$

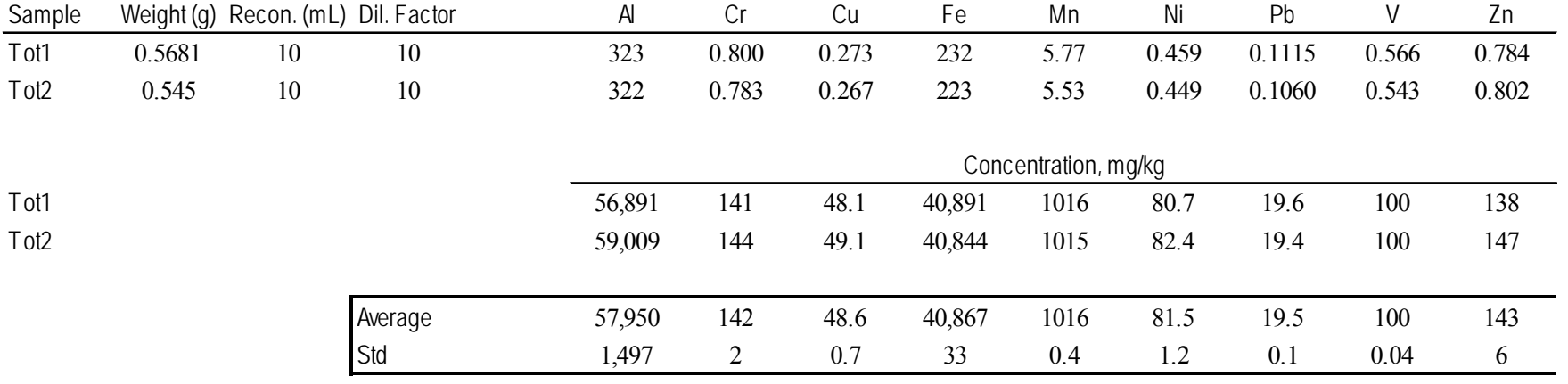

\begin{tabular}{|c|c|c|c|c|c|c|c|c|c|c|c|c|}
\hline \multicolumn{4}{|c|}{$6 / 5 / 2012: 74.5 \%<100 \mu \mathrm{m}$} & \multicolumn{9}{|c|}{ Concentration, $\mu \mathrm{g} / \mathrm{mL}$} \\
\hline Sample & Weight (g) & Recon. (mL) & Dil. Factor & $\mathrm{A}$ & $\mathrm{Cr}$ & $\mathrm{Cu}$ & $\mathrm{Fe}$ & $\mathrm{Mn}$ & $\mathrm{Ni}$ & $\mathrm{Pb}$ & $\mathrm{V}$ & $\mathrm{Zn}$ \\
\hline Tot1 & 0.5033 & 10 & 10 & 204 & 0.562 & 0.178 & 171 & 3.26 & 0.332 & 0.0798 & 0.370 & 0.559 \\
\hline \multirow[t]{2}{*}{ Tot2 } & 0.5002 & 10 & 10 & 212 & 0.568 & 0.177 & 172 & 3.28 & 0.328 & 0.0776 & 0.382 & 0.543 \\
\hline & & & & \multicolumn{9}{|c|}{ Concentration, $\mathrm{mg} / \mathrm{kg}$} \\
\hline Tot1 & & & & 40,572 & 112 & 35.4 & 33,976 & 648 & 66.0 & 15.9 & 74 & 111 \\
\hline \multirow[t]{3}{*}{ Tot2 } & & & & 42,343 & 114 & 35.4 & 34,326 & 656 & 65.6 & 15.5 & 76 & 109 \\
\hline & & & Average & 41,458 & 113 & 35.4 & 34,151 & 652 & 65.8 & 15.7 & 75 & 110 \\
\hline & & & Std & 1,252 & 1 & 0.01 & 248 & 6 & 0.3 & 0.2 & 2 & 2 \\
\hline
\end{tabular}


Near-total metal extractions, continued

\begin{tabular}{|c|c|c|c|c|c|c|c|c|c|c|c|c|}
\hline \multicolumn{4}{|c|}{ 9/17/2012: $61.4 \%<100 \mu \mathrm{m}$} & \multicolumn{9}{|c|}{ Concentration, $\mu \mathrm{g} / \mathrm{mL}$} \\
\hline Sample & Weight (g) & Recon. (mL) & Dil. Factor & $\mathrm{A}$ & $\mathrm{Cr}$ & $\mathrm{Cu}$ & $\mathrm{Fe}$ & $\mathrm{Mn}$ & $\mathrm{Ni}$ & $\mathrm{Pb}$ & V & $\mathrm{Zn}$ \\
\hline Tot1 & 0.5180 & 10 & 10 & 164 & 0.481 & 0.140 & 145 & 3.15 & 0.262 & 0.0645 & 0.316 & 0.425 \\
\hline \multirow[t]{2}{*}{ Tot2 } & 0.5416 & 10 & 10 & 180 & 0.535 & 0.154 & 154 & 3.41 & 0.277 & 0.0713 & 0.338 & 0.459 \\
\hline & & & & \multicolumn{9}{|c|}{ Concentration, $\mathrm{mg} / \mathrm{kg}$} \\
\hline Tot1 & & & & 31,622 & 93 & 27.1 & 27,896 & 608 & 50.5 & 12.5 & 61 & 82 \\
\hline \multirow[t]{3}{*}{ Tot2 } & & & & 33,272 & 99 & 28.5 & 28,342 & 630 & 51.2 & 13.2 & 62 & 85 \\
\hline & & & Average & 32,447 & 96 & 27.8 & 28,119 & 619 & 50.8 & 12.8 & 62 & 83 \\
\hline & & & Std & 1,167 & 4 & 1.0 & 316 & 15 & 0.5 & 0.5 & 1 & 2 \\
\hline
\end{tabular}

10/24/2012: $73.7 \%<100 \mu \mathrm{m}$

Sample Weight $(\mathrm{g})$ Recon. $(\mathrm{mL})$ Dil. Factor

\begin{tabular}{llll}
\hline Tot1 & 0.4973 & 10 & 10
\end{tabular}

$\begin{array}{llll}\text { Tot2 } & 0.5125 & 10 & 10\end{array}$

Tot1

Tot2

\begin{tabular}{lccccccccc}
\multicolumn{10}{c}{ Concentration, $\mathrm{mg} / \mathrm{kg}$} \\
\cline { 2 - 10 } & 40,861 & 115 & 34.7 & 35,653 & 1,095 & 68.8 & 16.9 & 76 & 113 \\
& 40,195 & 113 & 34.6 & 35,434 & 1,102 & 71.2 & 17.1 & 76 & 114 \\
& & & & & & & & \\
\hline Average & 40,528 & 114 & 34.7 & 35,543 & 1,099 & 70.0 & 17.0 & 76 & 114 \\
Std & 471 & 1 & 0.1 & 154 & 5 & 1.7 & 0.2 & 0.4 & 1 \\
\hline
\end{tabular}

\begin{tabular}{|c|c|c|c|c|c|c|c|c|c|c|c|c|}
\hline \multicolumn{4}{|c|}{$12 / 7 / 2012: 57.5 \%<100 \mu \mathrm{m}$} & \multicolumn{9}{|c|}{ Concentration, $\mu \mathrm{g} / \mathrm{mL}$} \\
\hline Sample & Weight (g) & Recon. $(\mathrm{mL})$ & Dil. Factor & Al & $\mathrm{Cr}$ & $\mathrm{Cu}$ & $\mathrm{Fe}$ & $\mathrm{Mn}$ & $\mathrm{Ni}$ & $\mathrm{Pb}$ & $\mathrm{V}$ & $\mathrm{Zn}$ \\
\hline Tot1 & 0.4337 & 10 & 10 & 192 & 0.550 & 0.150 & 159 & 3.51 & 0.303 & 0.062 & 0.394 & 0.485 \\
\hline \multirow[t]{2}{*}{ Tot2 } & 0.4022 & 10 & 10 & 178 & 0.506 & 0.141 & 151 & 3.31 & 0.296 & 0.063 & 0.367 & 0.469 \\
\hline & & & & \multicolumn{9}{|c|}{ Concentration, $\mathrm{mg} / \mathrm{kg}$} \\
\hline Tot1 & & & & 44,178 & 127 & 34.5 & 36,569 & 810 & 69.8 & 14.4 & 91 & 112 \\
\hline \multirow[t]{3}{*}{ Tot2 } & & & & 44,232 & 126 & 35.0 & 37,643 & 822 & 73.5 & 15.7 & 91 & 117 \\
\hline & & & Average & 44,205 & 126 & 34.7 & 37,106 & 816 & 71.6 & 15.0 & 91 & 114 \\
\hline & & & Std & 38 & 1 & 0.4 & 759 & 8 & 2.6 & 1.0 & 0.4 & 3 \\
\hline
\end{tabular}


Partial metal extraction

\begin{tabular}{|c|c|c|c|c|c|c|c|c|c|c|c|c|c|}
\hline \multicolumn{4}{|c|}{$1 / 17 / 2012$} & \multicolumn{10}{|c|}{ Concentration, $\mu \mathrm{g} / \mathrm{mL}$} \\
\hline Sample & Weight (g) & Recon. $(\mathrm{mL})$ & & $\mathrm{Ag}$ & $\mathrm{Al}$ & $\mathrm{Cr}$ & $\mathrm{Cu}$ & $\mathrm{Fe}$ & $\mathrm{Mn}$ & $\mathrm{Ni}$ & $\mathrm{Pb}$ & $\mathrm{V}$ & $\mathrm{Zn}$ \\
\hline $\mathrm{HCl} 1$ & 0.5002 & 12 & & 0.012 & 71.5 & 0.221 & 0.565 & 163 & 22.0 & 0.205 & 0.602 & 0.357 & 1.33 \\
\hline \multirow[t]{2}{*}{ HCL2 } & 0.4764 & 12 & & 0.012 & 68.3 & 0.210 & 0.546 & 155 & 21.2 & 0.197 & 0.568 & 0.342 & 1.25 \\
\hline & & & & \multicolumn{10}{|c|}{ Concentration, $\mathrm{mg} / \mathrm{kg}$} \\
\hline $\mathrm{HCl} 1$ & & & & 0.30 & 1,715 & 5.30 & 13.5 & 3,920 & 528 & 4.93 & 14.4 & 8.57 & 31.9 \\
\hline \multirow[t]{3}{*}{$\mathrm{HCl} 2$} & & & & 0.29 & 1,720 & 5.28 & 13.8 & 3,909 & 534 & 4.96 & 14.3 & 8.62 & 31.5 \\
\hline & & & Average & 0.29 & 1,718 & 5.29 & 13.7 & 3,915 & 531 & 4.94 & 14.4 & 8.59 & 31.7 \\
\hline & & & Std & 0.003 & 2 & 0.01 & 0.1 & 5 & 3 & 0.02 & 0.1 & 0.02 & 0.2 \\
\hline
\end{tabular}

\begin{tabular}{|c|c|c|c|c|c|c|c|c|c|c|c|c|c|}
\hline \multicolumn{4}{|l|}{$2 / 14 / 2012$} & \multicolumn{10}{|c|}{ Concentration, $\mu \mathrm{g} / \mathrm{mL}$} \\
\hline Sample & Weight (g) & Recon. $(\mathrm{mL})$ & & $\mathrm{Ag}$ & $\mathrm{Al}$ & $\mathrm{Cr}$ & $\mathrm{Cu}$ & $\mathrm{Fe}$ & $\mathrm{Mn}$ & $\mathrm{Ni}$ & $\mathrm{Pb}$ & $\mathrm{V}$ & $\mathrm{Zn}$ \\
\hline $\mathrm{HCl1}$ & 0.5150 & 12 & & 0.0157 & 71.4 & 0.219 & 0.657 & 167.5 & 30.1 & 0.217 & 0.626 & 0.335 & 1.479 \\
\hline \multirow[t]{2}{*}{ HCL2 } & 0.5142 & 12 & & 0.0158 & 70.6 & 0.211 & 0.651 & 163.5 & 29.7 & 0.216 & 0.618 & 0.320 & 1.457 \\
\hline & & & & \multicolumn{10}{|c|}{ Concentration, $\mathrm{mg} / \mathrm{kg}$} \\
\hline $\mathrm{HCl} 1$ & & & & 0.37 & 1,663 & 5.10 & 15.3 & 3,903 & 702 & 5.05 & 14.6 & 7.80 & 34.5 \\
\hline \multirow[t]{3}{*}{$\mathrm{HCl} 2$} & & & & 0.37 & 1,647 & 4.93 & 15.2 & 3,816 & 694 & 5.03 & 14.4 & 7.48 & 34.0 \\
\hline & & & Average & 0.37 & 1,655 & 5.01 & 15.3 & 3,859 & 698 & 5.04 & 14.5 & 7.64 & 34.2 \\
\hline & & & Std & 0.001 & 8 & 0.09 & 0.1 & 44 & 4 & 0.01 & 0.1 & 0.16 & 0.2 \\
\hline \multicolumn{4}{|c|}{$3 / 26 / 2012$} & \multicolumn{10}{|c|}{ Concentration, $\mu \mathrm{g} / \mathrm{mL}$} \\
\hline Sample & Weight (g) & Recon. $(\mathrm{mL})$ & & $\mathrm{Ag}$ & Al & $\mathrm{Cr}$ & $\mathrm{Cu}$ & $\mathrm{Fe}$ & $\mathrm{Mn}$ & $\mathrm{Ni}$ & $\mathrm{Pb}$ & V & $\mathrm{Zn}$ \\
\hline $\mathrm{HCl} 1$ & 0.5337 & 12 & & 0.0149 & 77.8 & 0.222 & 0.741 & 160 & 27.1 & 0.244 & 0.585 & 0.342 & 1.54 \\
\hline \multirow[t]{2}{*}{ HCL2 } & 0.5198 & 12 & & 0.0139 & 74.7 & 0.211 & 0.719 & 153 & 26.2 & 0.235 & 0.565 & 0.333 & 1.45 \\
\hline & & & & \multicolumn{10}{|c|}{ Concentration, $\mathrm{mg} / \mathrm{kg}$} \\
\hline $\mathrm{HCl} 1$ & & & & 0.34 & 1,749 & 4.98 & 16.7 & 3,600 & 609 & 5.47 & 13.2 & 7.69 & 34.6 \\
\hline \multirow[t]{3}{*}{$\mathrm{HCl} 2$} & & & & 0.32 & 1,723 & 4.86 & 16.6 & 3,541 & 604 & 5.42 & 13.0 & 7.69 & 33.5 \\
\hline & & & Average & 0.33 & 1,736 & 4.92 & 16.6 & 3,571 & 607 & 5.45 & 13.1 & 7.69 & 34.1 \\
\hline & & & Std & 0.01 & 13 & 0.06 & 0.03 & 29 & 3 & 0.03 & 0.1 & 0.004 & 0.5 \\
\hline
\end{tabular}


Partial metal extraction, continued

\begin{tabular}{|c|c|c|c|c|c|c|c|c|c|c|c|c|c|}
\hline \multicolumn{4}{|c|}{$4 / 25 / 2012$} & \multicolumn{10}{|c|}{ Concentration, $\mu \mathrm{g} / \mathrm{mL}$} \\
\hline Sample & Weight (g) & Recon. $(\mathrm{mL})$ & & $\mathrm{Ag}$ & $\mathrm{Al}$ & $\mathrm{Cr}$ & $\mathrm{Cu}$ & $\mathrm{Fe}$ & $\mathrm{Mn}$ & $\mathrm{Ni}$ & $\mathrm{Pb}$ & $\mathrm{V}$ & $\mathrm{Zn}$ \\
\hline $\mathrm{HCl} 1$ & 0.5401 & 12 & & 0.0110 & 74.3 & 0.221 & 0.621 & 170.6 & 22.4 & 0.223 & 0.533 & 0.304 & 1.392 \\
\hline \multirow[t]{2}{*}{ HCL2 } & 0.5288 & 12 & & 0.0111 & 72.0 & 0.207 & 0.614 & 165.3 & 21.9 & 0.216 & 0.534 & 0.292 & 1.350 \\
\hline & & & & \multicolumn{10}{|c|}{ Concentration, $\mathrm{mg} / \mathrm{kg}$} \\
\hline $\mathrm{HCl} 1$ & & & & 0.24 & 1,650 & 4.91 & 13.8 & 3,790 & 499 & 4.94 & 11.8 & 6.76 & 30.9 \\
\hline \multirow[t]{3}{*}{$\mathrm{HCl} 2$} & & & & 0.25 & 1,633 & 4.70 & 13.9 & 3,751 & 498 & 4.91 & 12.1 & 6.63 & 30.6 \\
\hline & & & Average & 0.25 & 1,641 & 4.81 & 13.9 & 3,771 & 498 & 4.93 & 12.0 & 6.70 & 30.8 \\
\hline & & & Std & 0.004 & 8 & 0.11 & 0.1 & 20 & 0.5 & 0.02 & 0.1 & 0.07 & 0.1 \\
\hline
\end{tabular}

\begin{tabular}{|c|c|c|c|c|c|c|c|c|c|c|c|c|c|}
\hline \multicolumn{4}{|c|}{$5 / 14 / 2012$} & \multicolumn{10}{|c|}{ Concentration, $\mu \mathrm{g} / \mathrm{mL}$} \\
\hline Sample & Weight (g) & Recon. $(\mathrm{mL})$ & & $\mathrm{Ag}$ & $\mathrm{Al}$ & $\mathrm{Cr}$ & $\mathrm{Cu}$ & $\mathrm{Fe}$ & $\mathrm{Mn}$ & $\mathrm{Ni}$ & $\mathrm{Pb}$ & $\mathrm{V}$ & $\mathrm{Zn}$ \\
\hline $\mathrm{HCl} 1$ & 0.5292 & 12 & & 0.0158 & 88.5 & 0.250 & 0.826 & 180 & 25.7 & 0.250 & 0.639 & 0.315 & 1.93 \\
\hline \multirow[t]{2}{*}{ HCL2 } & 0.5321 & 12 & & 0.0159 & 89.9 & 0.252 & 0.848 & 182 & 25.6 & 0.254 & 0.642 & 0.322 & 1.95 \\
\hline & & & & \multicolumn{10}{|c|}{ Concentration, $\mathrm{mg} / \mathrm{kg}$} \\
\hline $\mathrm{HCl} 1$ & & & & 0.36 & 2,007 & 5.67 & 18.7 & 4,084 & 583 & 5.66 & 14.5 & 7.13 & 43.8 \\
\hline \multirow[t]{3}{*}{$\mathrm{HCl} 2$} & & & & 0.36 & 2,028 & 5.69 & 19.1 & 4,114 & 577 & 5.73 & 14.5 & 7.27 & 44.0 \\
\hline & & & Average & 0.36 & 2,018 & 5.68 & 18.9 & 4,099 & 580 & 5.69 & 14.5 & 7.20 & 43.9 \\
\hline & & & Std & 0.0002 & 10 & 0.01 & 0.2 & 15 & 3 & 0.03 & 0.01 & 0.07 & 0.1 \\
\hline \multicolumn{4}{|l|}{$6 / 5 / 2012$} & \multicolumn{10}{|c|}{ Concentration, $\mu \mathrm{g} / \mathrm{mL}$} \\
\hline Sample & Weight (g) & Recon. $(\mathrm{mL})$ & & $\mathrm{Ag}$ & Al & $\mathrm{Cr}$ & $\mathrm{Cu}$ & $\mathrm{Fe}$ & $\mathrm{Mn}$ & $\mathrm{Ni}$ & $\mathrm{Pb}$ & V & $\mathrm{Zn}$ \\
\hline $\mathrm{HCl} 1$ & 0.4891 & 12 & & 0.0089 & 60.1 & 0.178 & 0.508 & 138 & 13.40 & 0.204 & 0.498 & 0.267 & 1.24 \\
\hline \multirow[t]{2}{*}{$\mathrm{HCl} 2$} & 0.4938 & 12 & & 0.0086 & 59.3 & 0.169 & 0.514 & 134 & 13.18 & 0.200 & 0.492 & 0.267 & 1.22 \\
\hline & & & & \multicolumn{10}{|c|}{ Concentration, $\mathrm{mg} / \mathrm{kg}$} \\
\hline $\mathrm{HCl} 1$ & & & & 0.22 & 1,473 & 4.36 & 12.47 & 3,383 & 329 & 5.00 & 12.21 & 6.55 & 30.5 \\
\hline \multirow[t]{3}{*}{$\mathrm{HCl} 2$} & & & & 0.21 & 1,441 & 4.12 & 12.49 & 3,261 & 320 & 4.86 & 11.95 & 6.48 & 29.7 \\
\hline & & & Average & 0.21 & 1,457 & 4.24 & 12.48 & 3,322 & 325 & 4.93 & 12.08 & 6.51 & 30.1 \\
\hline & & & Std & 0.005 & 16 & 0.12 & 0.01 & 61 & 4 & 0.07 & 0.13 & 0.03 & 0.4 \\
\hline
\end{tabular}


Partial metal extraction, continued

\begin{tabular}{|c|c|c|c|c|c|c|c|c|c|c|c|c|c|}
\hline \multicolumn{4}{|c|}{$9 / 17 / 2012$} & \multicolumn{10}{|c|}{ Concentration, $\mu \mathrm{g} / \mathrm{mL}$} \\
\hline Sample & Weight $(\mathrm{g})$ & Recon. $(\mathrm{mL})$ & & $\mathrm{Ag}$ & $\mathrm{Al}$ & $\mathrm{Cr}$ & $\mathrm{Cu}$ & $\mathrm{Fe}$ & $\mathrm{Mn}$ & $\mathrm{Ni}$ & $\mathrm{Pb}$ & $\mathrm{V}$ & $\mathrm{Zn}$ \\
\hline $\mathrm{HCl} 1$ & 0.5217 & 12 & & 0.0128 & 46.5 & 0.168 & 0.451 & 133.8 & 15.1 & 0.196 & 0.437 & 0.251 & 0.956 \\
\hline \multirow[t]{2}{*}{$\mathrm{HCl} 2$} & 0.524 & 12 & & 0.0129 & 47.1 & 0.166 & 0.450 & 137.4 & 14.9 & 0.198 & 0.439 & 0.248 & 0.963 \\
\hline & & & & \multicolumn{10}{|c|}{ Concentration, $\mathrm{mg} / \mathrm{kg}$} \\
\hline $\mathrm{HCl} 1$ & & & & 0.29 & 1,069 & 3.87 & 10.4 & 3,078 & 347 & 4.51 & 10.0 & 5.78 & 22.0 \\
\hline \multirow[t]{3}{*}{$\mathrm{HCl} 2$} & & & & 0.30 & 1,077 & 3.80 & 10.3 & 3,147 & 341 & 4.53 & 10.1 & 5.67 & 22.1 \\
\hline & & & Average & 0.29 & 1,073 & 3.84 & 10.3 & 3,112 & 344 & 4.52 & 10.0 & 5.73 & 22.0 \\
\hline & & & Std & 0.0005 & 4 & 0.04 & 0.03 & 34 & 3 & 0.01 & 0.004 & 0.06 & 0.03 \\
\hline
\end{tabular}

\begin{tabular}{|c|c|c|c|c|c|c|c|c|c|c|c|c|c|}
\hline \multicolumn{8}{|c|}{ 10/24/2012 } & \multicolumn{6}{|c|}{ Concentration, $\mu \mathrm{g} / \mathrm{mL}$} \\
\hline Sample & Weight (g) & Recon. $(\mathrm{mL})$ & & $\mathrm{Ag}$ & $\mathrm{Al}$ & $\mathrm{Cr}$ & $\mathrm{Cu}$ & $\mathrm{Fe}$ & $\mathrm{Mn}$ & $\mathrm{Ni}$ & $\mathrm{Pb}$ & V & $\mathrm{Zn}$ \\
\hline $\mathrm{HCl} 1$ & 0.5019 & 12 & & 0.0156 & 58.3 & 0.188 & 0.573 & 156 & 28.2 & 0.198 & 0.527 & 0.284 & 1.22 \\
\hline \multirow[t]{2}{*}{$\mathrm{HCl} 2$} & 0.5069 & 12 & & 0.0165 & 60.3 & 0.198 & 0.594 & 163 & 28.8 & 0.206 & 0.531 & 0.297 & 1.27 \\
\hline & & & & \multicolumn{10}{|c|}{ Concentration, $\mathrm{mg} / \mathrm{kg}$} \\
\hline $\mathrm{HCl} 1$ & & & & 0.37 & 1,393 & 4.48 & 13.69 & 3,737 & 674 & 4.73 & 12.6 & 6.78 & 29.1 \\
\hline \multirow[t]{3}{*}{$\mathrm{HCl} 2$} & & & & 0.39 & 1,428 & 4.69 & 14.06 & 3,852 & 683 & 4.87 & 12.6 & 7.03 & 30.1 \\
\hline & & & Average & 0.38 & 1,410 & 4.59 & 13.88 & 3,794 & 678 & 4.80 & 12.6 & 6.91 & 29.6 \\
\hline & & & Std & 0.01 & 18 & 0.10 & 0.18 & 57 & 4 & 0.07 & 0.01 & 0.13 & 0.5 \\
\hline
\end{tabular}

\begin{tabular}{|c|c|c|c|c|c|c|c|c|c|c|c|c|c|}
\hline \multicolumn{4}{|c|}{$12 / 7 / 2012$} & \multicolumn{10}{|c|}{ Concentration, $\mu \mathrm{g} / \mathrm{mL}$} \\
\hline Sample & Weight (g) & Recon. $(\mathrm{mL})$ & & $\mathrm{Ag}$ & $\mathrm{Al}$ & $\mathrm{Cr}$ & $\mathrm{Cu}$ & $\mathrm{Fe}$ & $\mathrm{Mn}$ & $\mathrm{Ni}$ & $\mathrm{Pb}$ & $\mathrm{V}$ & $\mathrm{Zn}$ \\
\hline $\mathrm{HCl1}$ & 0.4033 & 12 & & 0.0081 & 56.7 & 0.164 & 0.474 & 133 & 16.2 & 0.207 & 0.384 & 0.261 & 0.97 \\
\hline \multirow[t]{2}{*}{$\mathrm{HCl} 2$} & 0.4721 & 12 & & 0.0094 & 65.1 & 0.185 & 0.551 & 150 & 17.8 & 0.233 & 0.456 & 0.290 & 1.06 \\
\hline & & & & \multicolumn{10}{|c|}{ Concentration, $\mathrm{mg} / \mathrm{kg}$} \\
\hline $\mathrm{HCl} 1$ & & & & 0.24 & 1,686 & 4.89 & 14.1 & 3,954 & 483 & 6.17 & 11.4 & 7.75 & 28.8 \\
\hline \multirow[t]{3}{*}{$\mathrm{HCl} 2$} & & & & 0.24 & 1,654 & 4.71 & 14.0 & 3,820 & 451 & 5.91 & 11.6 & 7.37 & 27.0 \\
\hline & & & Average & 0.24 & 1,670 & 4.80 & 14.0 & 3,887 & 467 & 6.04 & 11.5 & 7.56 & 27.9 \\
\hline & & & Std & 0.001 & 16 & 0.09 & 0.05 & 67 & 16 & 0.13 & 0.1 & 0.19 & 0.9 \\
\hline
\end{tabular}


Appendix 3. Trace-metal concentrations in the clam Macoma petalum collected at the Palo Alto, Calif., mudflat, 2012.

[Each monthly collection is reported on two pages. The first page contains the following summary statistics:

- Mean concentrations in milligram per kilogram dry tissue weight $(\mathrm{mg} / \mathrm{kg})$.

- STD is the standard deviation of the mean.

- $\quad$ SEM is the standard error of the mean.

- $\quad C V$ percent is the coefficient of variation.

- $\quad r$ wt $x[$ is the correlation coefficient for the concentration versus weight correlation for each element.

- $X 100 \mathrm{mg}$ is the concentration interpolated from the above regression for a 100-milligram animal.

- $r|x|$ is the correlation coefficient for the concentration versus shell length regression.

- X $20 \mathrm{~mm}$ and $X 25 \mathrm{~mm}$ are concentrations interpolated from the regression for 20-millimeter and 25-millimeter animals, respectively.

Soft-tissue weights for animals having shell lengths of 15,20 , and $25 \mathrm{~mm}$ shell length were predicted from a linear regression of log tissue dry weight vs log average shell length for each monthly collection. Predicted tissue weights for a 25 -mm clam defined the condition index $(\mathrm{Cl})$, which was used to interpret the physiological condition of the population. Content (a measure of metal bioaccumulation that is standardized to tissue mass) is shown for $15-\mathrm{mm}, 20-\mathrm{mm}$, and $25-\mathrm{mm}$ animals. The second page shows the analysis of each composite within the sample, the number of animals in each composite, concentration as calculated from sample dry weight and the dilution factor and the metal content for each composite.] 


\begin{tabular}{|c|c|c|c|c|c|c|c|c|}
\hline \multirow{3}{*}{$\begin{array}{l}\text { Station: } \\
\text { Date: }\end{array}$} & \multirow{2}{*}{$\begin{array}{l}\text { Palo Alto } \\
\text { 1/17/2012 }\end{array}$} & \multicolumn{3}{|c|}{ Statistical Summary } & \multirow[b]{3}{*}{$\mathrm{Ni}$} & \multirow[b]{3}{*}{$\mathrm{Pb}$} & \multirow[b]{3}{*}{$\mathrm{V}$} & \multirow[b]{3}{*}{$\mathrm{Zn}$} \\
\hline & & & & & & & & \\
\hline & $\mathrm{Ag}$ & $\mathrm{Cd}$ & $\mathrm{Cr}$ & $\mathrm{Cu}$ & & & & \\
\hline Mean $(\mathrm{mg} / \mathrm{kg})$ & 4.62 & 0.72 & 6.57 & 44.4 & 5.87 & 1.30 & 5.14 & 377 \\
\hline STD & 1.46 & 0.26 & 2.59 & 7.9 & 1.76 & 0.52 & 2.02 & 118 \\
\hline SEM & 0.42 & 0.08 & 0.75 & 2.3 & 0.51 & 0.15 & 0.58 & 34 \\
\hline $\mathrm{CV} \%$ & 31.6 & 37 & 39.4 & 17.7 & 30.1 & 40.0 & 39.4 & 31.3 \\
\hline$n$ & 12 & 12 & 12 & 12 & 12 & 12 & 12 & 12 \\
\hline rwtx [] & 0.139 & 0.61 & 0.587 & 0.498 & 0.661 & 0.717 & 0.704 & 0.712 \\
\hline X 100mg & 4.34 & 0.94 & 8.65 & 49.8 & 7.46 & 1.81 & 7.08 & 492 \\
\hline $\mathrm{rlx}[\mathrm{]}$ & 0.104 & 0.58 & 0.504 & 0.484 & 0.594 & 0.655 & 0.628 & 0.621 \\
\hline X 20mm & 4.62 & 0.71 & 6.52 & 44.3 & 5.83 & 1.29 & 5.09 & 374 \\
\hline$X 25 \mathrm{~mm}$ & 4.45 & 0.88 & 8.03 & 48.7 & 7.04 & 1.68 & 6.55 & 458 \\
\hline
\end{tabular}

Estimated content (ug) for $15 \mathrm{~mm}$ and $20 \mathrm{~mm}$ clam

\begin{tabular}{|c|c|c|c|c|c|c|c|c|}
\hline & $\mathrm{Ag}$ & $\mathrm{Cd}$ & $\mathrm{Cr}$ & $\mathrm{Cu}$ & $\mathrm{Ni}$ & $\mathrm{Pb}$ & V & $\mathrm{Zn}$ \\
\hline $20 \mathrm{~mm}$ & 0.215 & 0.034 & 0.309 & 2.17 & 0.282 & 0.0613 & 0.242 & 18.0 \\
\hline $25 \mathrm{~mm}$ & 0.358 & 0.074 & 0.651 & 4.34 & 0.597 & 0.138 & 0.538 & 38.3 \\
\hline
\end{tabular}

$\begin{array}{rr}0.023 \mathrm{gm} & 0.049 \mathrm{gm} \\ 23 \mathrm{mg} & 49 \mathrm{mg}\end{array}$

Estimated weight for $25 \mathrm{~mm}$ clam

$0.091 \mathrm{gm}$

$91 \mathrm{mg}$ 


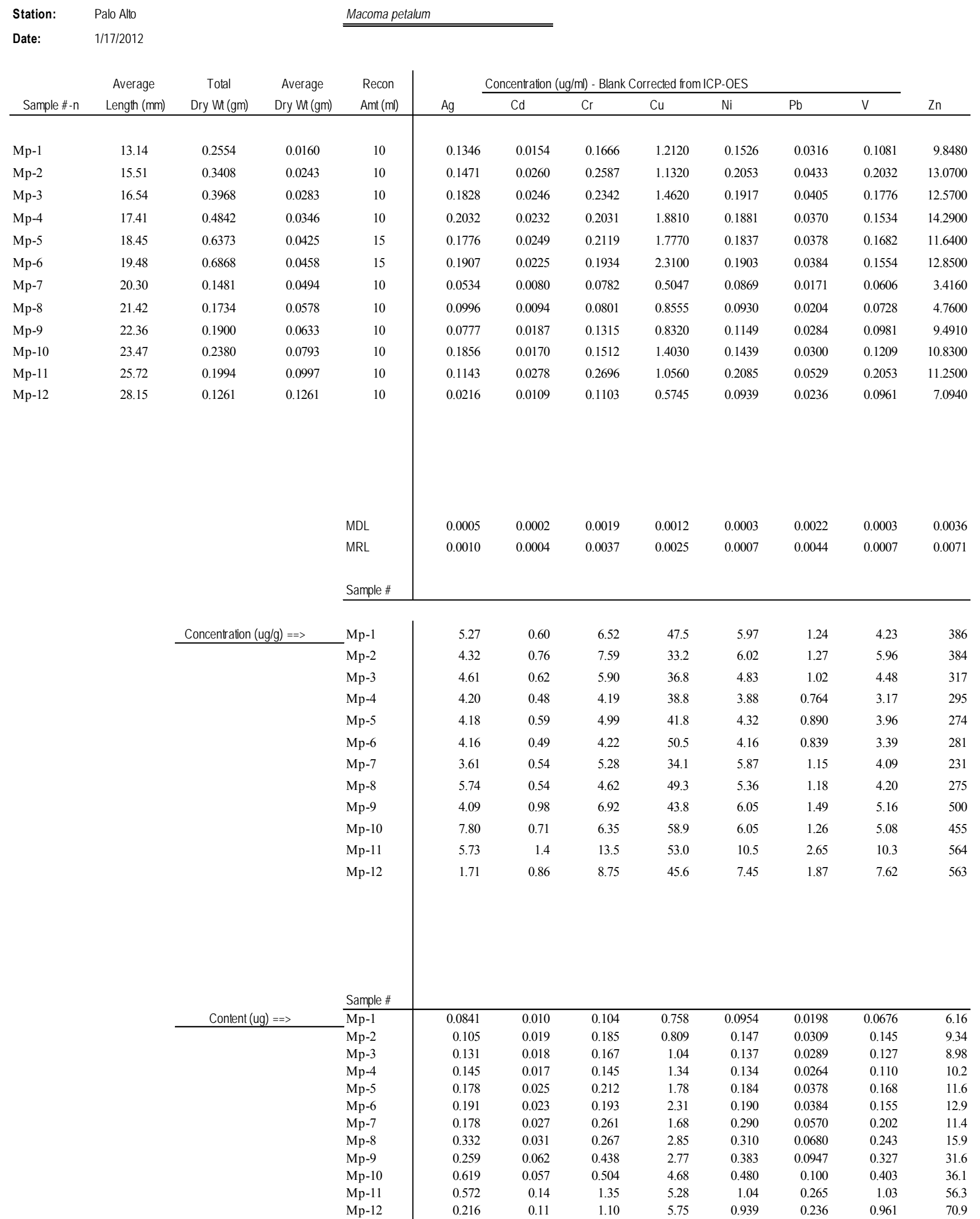




\begin{tabular}{|c|c|c|c|c|c|c|c|c|}
\hline \multirow{3}{*}{$\begin{array}{l}\text { Station: } \\
\text { Date: }\end{array}$} & \multirow{2}{*}{$\begin{array}{l}\text { Palo Alto } \\
\text { 2/14/2012 }\end{array}$} & \multicolumn{3}{|c|}{ Statistical Summary } & \multirow[b]{3}{*}{$\mathrm{Ni}$} & \multirow[b]{3}{*}{$\mathrm{Pb}$} & \multirow[b]{3}{*}{$\mathrm{V}$} & \multirow[b]{3}{*}{$\mathrm{Zn}$} \\
\hline & & & & & & & & \\
\hline & $\mathrm{Ag}$ & $\mathrm{Cd}$ & $\mathrm{Cr}$ & $\mathrm{Cu}$ & & & & \\
\hline Mean $(\mathrm{mg} / \mathrm{kg})$ & 3.92 & 0.44 & 3.88 & 42.3 & 4.15 & 0.823 & 3.14 & 316 \\
\hline STD & 0.44 & 0.06 & 0.57 & 6.1 & 0.50 & 0.102 & 0.44 & 22 \\
\hline SEM & 0.13 & 0.02 & 0.16 & 1.8 & 0.14 & 0.030 & 0.13 & 6 \\
\hline $\mathrm{CV} \%$ & 11.3 & 13 & 14.6 & 14.4 & 12.1 & 12.4 & 14.1 & 7.0 \\
\hline$n$ & 12 & 12 & 12 & 12 & 12 & 12 & 12 & 12 \\
\hline rwtx [] & 0.195 & 0.35 & 0.224 & 0.190 & 0.174 & 0.046 & 0.073 & 0.296 \\
\hline X 100mg & 4.11 & 0.49 & 4.16 & 44.8 & 3.96 & 0.81 & 3.207 & 302 \\
\hline $\mathrm{rlx}[\mathrm{]}$ & 0.230 & 0.32 & 0.157 & 0.151 & 0.238 & 0.090 & 0.037 & 0.341 \\
\hline X 20mm & 3.98 & 0.45 & 3.93 & 42.8 & 4.09 & 0.818 & 3.14 & 312 \\
\hline$X 25 \mathrm{~mm}$ & 4.10 & 0.48 & 4.04 & 43.9 & 3.94 & 0.807 & 3.165 & 303 \\
\hline
\end{tabular}

Estimated content (ug) for $15 \mathrm{~mm}$ and $20 \mathrm{~mm}$ clam

\begin{tabular}{|c|c|c|c|c|c|c|c|c|}
\hline & $\mathrm{Ag}$ & $\mathrm{Cd}$ & $\mathrm{Cr}$ & $\mathrm{Cu}$ & $\mathrm{Ni}$ & $\mathrm{Pb}$ & V & $\mathrm{Zn}$ \\
\hline $20 \mathrm{~mm}$ & 0.233 & 0.026 & 0.229 & 2.48 & 0.238 & 0.0478 & 0.183 & 18.3 \\
\hline $25 \mathrm{~mm}$ & 0.410 & 0.047 & 0.398 & 4.31 & 0.396 & 0.0809 & 0.315 & 30.9 \\
\hline
\end{tabular}

$\begin{array}{rr}0.029 \mathrm{gm} & 0.059 \mathrm{gm} \\ 29 \mathrm{mg} & 59 \mathrm{mg}\end{array}$

Estimated weight for $25 \mathrm{~mm}$ clam

$0.101 \mathrm{gm}$

$101 \mathrm{mg}$ 


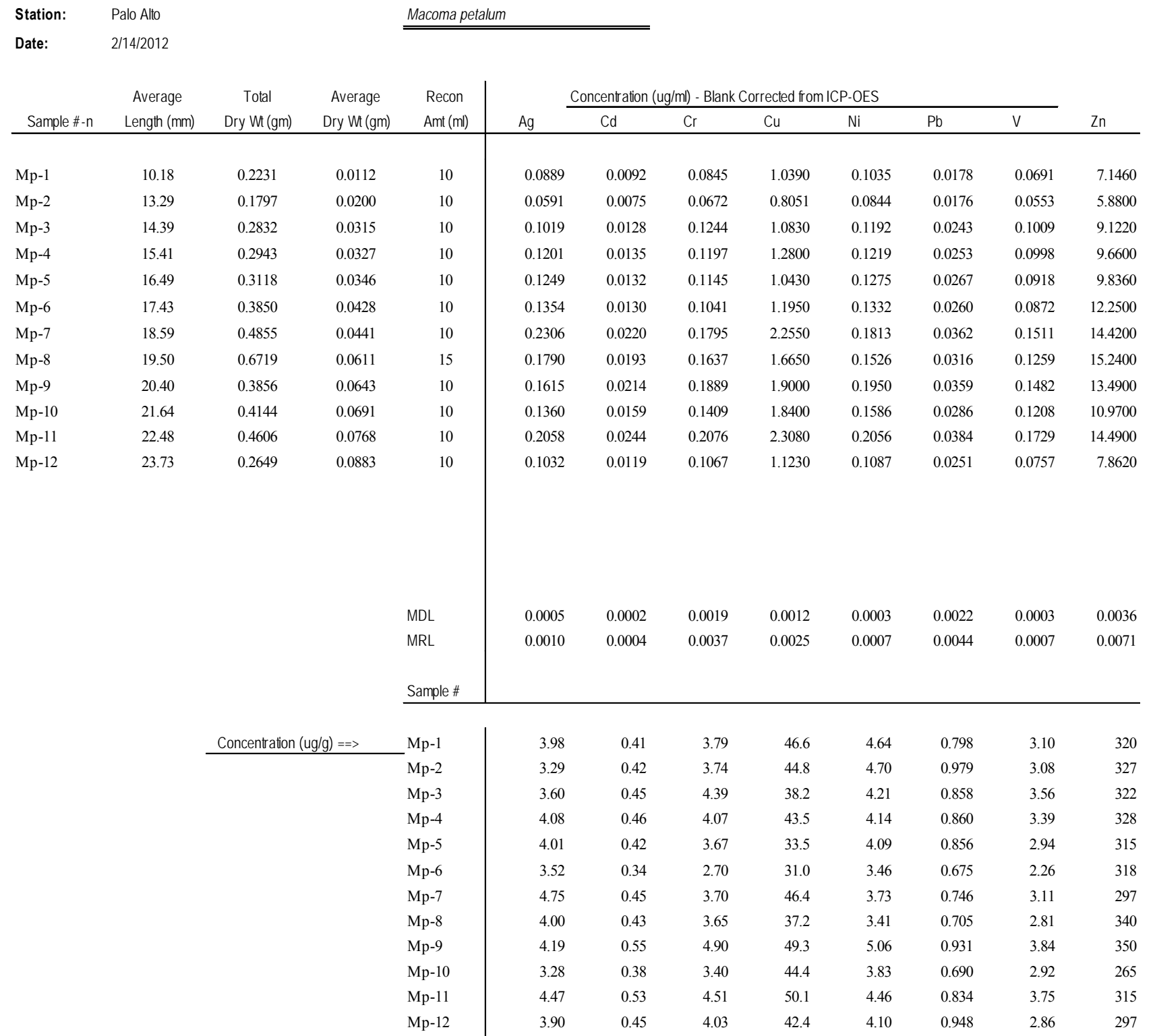

\begin{tabular}{|c|c|c|c|c|c|c|c|c|c|}
\hline \multirow[b]{2}{*}{ Content (ug) ==> } & Sample \# & \multirow[b]{2}{*}{0.0445} & \multirow[b]{2}{*}{0.0046} & \multirow[b]{2}{*}{0.0423} & \multirow[b]{2}{*}{0.5195} & \multirow[b]{2}{*}{0.0518} & \multirow[b]{2}{*}{0.00890} & \multirow[b]{2}{*}{0.0346} & \multirow[b]{2}{*}{3.57} \\
\hline & Mp-1 & & & & & & & & \\
\hline & $\mathrm{Mp}-2$ & 0.0657 & 0.0083 & 0.0747 & 0.8946 & 0.0938 & 0.0196 & 0.0614 & 6.53 \\
\hline & Mp-3 & 0.113 & 0.014 & 0.138 & 1.20 & 0.132 & 0.0270 & 0.112 & 10.1 \\
\hline & Mp-4 & 0.133 & 0.015 & 0.133 & 1.42 & 0.135 & 0.0281 & 0.111 & 10.7 \\
\hline & Mp-5 & 0.139 & 0.015 & 0.127 & 1.16 & 0.142 & 0.0297 & 0.102 & 10.9 \\
\hline & Mp-6 & 0.150 & 0.014 & 0.116 & 1.33 & 0.148 & 0.0289 & 0.0969 & 13.6 \\
\hline & Mp-7 & 0.210 & 0.020 & 0.163 & 2.05 & 0.165 & 0.0329 & 0.137 & 13.1 \\
\hline & Mp-8 & 0.244 & 0.026 & 0.223 & 2.27 & 0.208 & 0.0431 & 0.172 & 20.8 \\
\hline & Mp-9 & 0.269 & 0.036 & 0.315 & 3.17 & 0.325 & 0.0598 & 0.247 & 22.5 \\
\hline & Mp-10 & 0.227 & 0.027 & 0.235 & 3.07 & 0.264 & 0.0477 & 0.201 & 18.3 \\
\hline & Mp-11 & 0.343 & 0.041 & 0.346 & 3.85 & 0.343 & 0.0640 & 0.288 & 24.2 \\
\hline & Mp-12 & 0.344 & 0.040 & 0.356 & 3.74 & 0.362 & 0.0837 & 0.252 & 26.2 \\
\hline
\end{tabular}




\begin{tabular}{|c|c|c|c|c|c|c|c|c|}
\hline \multirow{3}{*}{$\begin{array}{l}\text { Station: } \\
\text { Date: }\end{array}$} & \multirow{2}{*}{$\begin{array}{l}\text { Palo Alto } \\
3 / 26 / 2012\end{array}$} & \multicolumn{3}{|c|}{ Statistical Summary } & \multirow[b]{3}{*}{$\mathrm{Ni}$} & \multirow[b]{3}{*}{$\mathrm{Pb}$} & \multirow[b]{3}{*}{ V } & \multirow[b]{3}{*}{$\mathrm{Zn}$} \\
\hline & & & & & & & & \\
\hline & $\mathrm{Ag}$ & $\mathrm{Cd}$ & $\mathrm{Cr}$ & $\mathrm{Cu}$ & & & & \\
\hline $\operatorname{Mean}(\mathrm{mg} / \mathrm{kg})$ & 1.80 & 0.35 & 3.03 & 23.8 & 3.73 & 0.786 & 2.76 & 239 \\
\hline STD & 0.75 & 0.06 & 0.61 & 5.2 & 0.62 & 0.165 & 0.56 & 46 \\
\hline SEM & 0.22 & 0.02 & 0.18 & 1.5 & 0.18 & 0.048 & 0.16 & 13 \\
\hline CV\% & 41.8 & 17 & 20.1 & 21.9 & 16.6 & 21.0 & 20.3 & 19.4 \\
\hline$n$ & 12 & 12 & 12 & 12 & 12 & 12 & 12 & 12 \\
\hline rwtx [] & 0.797 & 0.69 & 0.609 & 0.671 & 0.513 & 0.582 & 0.659 & 0.024 \\
\hline X 100mg & 1.915 & 0.36 & 3.107 & 24.5 & 3.79 & 0.805 & 2.829 & 239 \\
\hline$r \mid x[]$ & 0.7216 & 0.60 & 0.498 & 0.619 & 0.413 & 0.496 & 0.565 & 0.037 \\
\hline $\mathrm{X} 20 \mathrm{~mm}$ & 1.865 & 0.36 & 3.072 & 24.2 & 3.76 & 0.796 & 2.796 & 239 \\
\hline $\mathrm{X} 25 \mathrm{~mm}$ & 2.373 & 0.39 & 3.356 & 27.2 & 4.00 & 0.873 & 3.093 & 241 \\
\hline
\end{tabular}

Estimated content (ug) for $15 \mathrm{~mm}$ and $20 \mathrm{~mm}$ clam

\begin{tabular}{|c|c|c|c|c|c|c|c|c|}
\hline & $\mathrm{Ag}$ & $\mathrm{Cd}$ & $\mathrm{Cr}$ & $\mathrm{Cu}$ & $\mathrm{Ni}$ & $\mathrm{Pb}$ & V & $\mathrm{Zn}$ \\
\hline $20 \mathrm{~mm}$ & 0.151 & 0.030 & 0.254 & 2.01 & 0.312 & 0.0657 & 0.231 & 19.6 \\
\hline $25 \mathrm{~mm}$ & 0.348 & 0.059 & 0.499 & 4.08 & 0.599 & 0.128 & 0.462 & 36.2 \\
\hline
\end{tabular}

$\begin{array}{rr}0.038 \mathrm{gm} & 0.084 \mathrm{gm} \\ 38 \mathrm{mg} & 84 \mathrm{mg}\end{array}$

Estimated weight for $25 \mathrm{~mm}$ clam

$0.156 \mathrm{gm}$

$156 \mathrm{mg}$ 


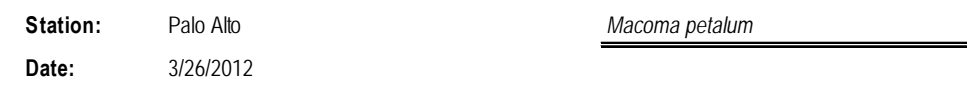

\begin{tabular}{|c|c|c|c|c|c|c|c|c|c|c|c|c|}
\hline \multirow[b]{2}{*}{ Sample \#-n } & \multirow{2}{*}{$\begin{array}{c}\text { Average } \\
\text { Length (mm) }\end{array}$} & \multirow{2}{*}{$\begin{array}{c}\text { Total } \\
\text { Dry Wt (gm) }\end{array}$} & \multirow{2}{*}{$\begin{array}{c}\text { Average } \\
\text { Dry Wt (gm) }\end{array}$} & \multirow{2}{*}{$\begin{array}{c}\text { Recon } \\
\text { Amt (ml) }\end{array}$} & \multicolumn{7}{|c|}{ Concentration (ug/ml) - Blank Corrected from ICP-OES } & \multirow[b]{2}{*}{$\mathrm{Zn}$} \\
\hline & & & & & $\mathrm{Ag}$ & $\mathrm{Cd}$ & $\mathrm{Cr}$ & $\mathrm{Cu}$ & $\mathrm{Ni}$ & $\mathrm{Pb}$ & $\mathrm{V}$ & \\
\hline Mp-1 & 10.99 & 0.2561 & 0.0142 & 10 & 0.0257 & 0.0089 & 0.0819 & 0.5314 & 0.1047 & 0.0219 & 0.0713 & 5.3210 \\
\hline $\mathrm{Mp}-2$ & 12.43 & 0.2462 & 0.0189 & 10 & 0.0299 & 0.0078 & 0.0655 & 0.5742 & 0.0987 & 0.0193 & 0.0567 & 6.5380 \\
\hline $\mathrm{Mp}-3$ & 14.74 & 0.4341 & 0.0395 & 10 & 0.0575 & 0.0138 & 0.1208 & 0.7943 & 0.1413 & 0.0300 & 0.1104 & 8.8100 \\
\hline Mp-4 & 16.56 & 0.3358 & 0.0560 & 10 & 0.0794 & 0.0117 & 0.1027 & 0.8894 & 0.1188 & 0.0259 & 0.0932 & 8.0790 \\
\hline Mp-5 & 17.53 & 0.4006 & 0.0668 & 10 & 0.0616 & 0.0127 & 0.1164 & 0.7728 & 0.1355 & 0.0276 & 0.1033 & 9.6860 \\
\hline Mp-6 & 18.66 & 0.5631 & 0.0704 & 10 & 0.0637 & 0.0132 & 0.1039 & 0.9538 & 0.1519 & 0.0337 & 0.0959 & 11.7900 \\
\hline Mp-7 & 19.69 & 0.5259 & 0.0877 & 10 & 0.0897 & 0.0190 & 0.1690 & 1.3390 & 0.1795 & 0.0359 & 0.1568 & 12.9400 \\
\hline Mp-8 & 20.42 & 0.7578 & 0.0947 & 15 & 0.0712 & 0.0198 & 0.1667 & 1.0210 & 0.1921 & 0.0379 & 0.1542 & 13.0500 \\
\hline Мp-9 & 22.19 & 0.7030 & 0.1172 & 15 & 0.0829 & 0.0144 & 0.1143 & 1.0920 & 0.1480 & 0.0311 & 0.1036 & 12.7900 \\
\hline Mp-10 & 23.92 & 0.6685 & 0.1114 & 15 & 0.0908 & 0.0166 & 0.1319 & 1.3140 & 0.1772 & 0.0358 & 0.1269 & 12.7200 \\
\hline $\mathrm{Mp}-11$ & 26.68 & 0.3899 & 0.1950 & 10 & 0.1446 & 0.0183 & 0.1564 & 1.3660 & 0.1740 & 0.0358 & 0.1453 & 11.8800 \\
\hline $\mathrm{Mp}-12$ & 28.29 & 0.1912 & 0.1912 & 10 & 0.0454 & 0.0082 & 0.0773 & 0.5105 & 0.0950 & 0.0235 & 0.0685 & 2.5030 \\
\hline
\end{tabular}

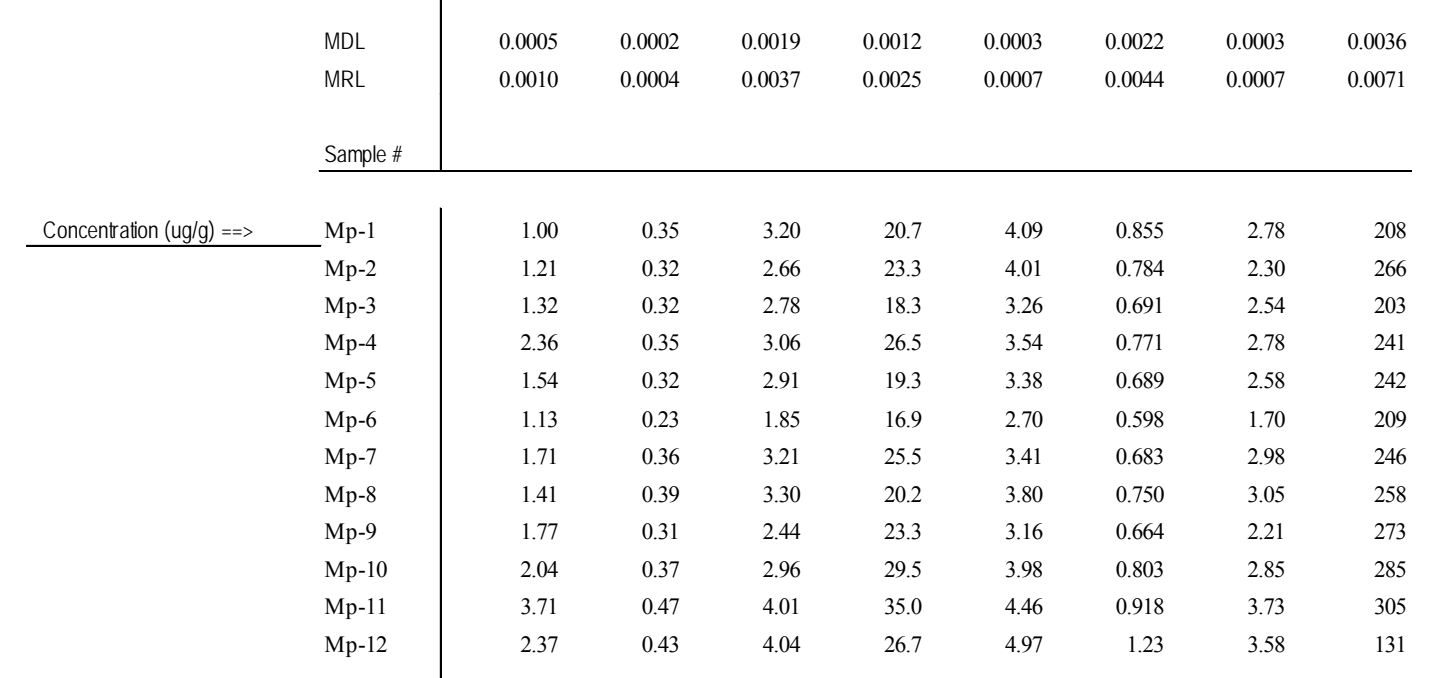

\begin{tabular}{|c|c|c|c|c|c|c|c|c|c|}
\hline \multirow[b]{2}{*}{ Content $($ ug $)==>$} & \multirow{2}{*}{$\frac{\text { Sample \# }}{\mathrm{Mp}-1}$} & \multirow[b]{2}{*}{0.0143} & \multirow[b]{2}{*}{0.0049} & \multirow[b]{2}{*}{0.0455} & \multirow[b]{2}{*}{0.295} & \multirow[b]{2}{*}{0.0582} & \multirow[b]{2}{*}{0.0122} & \multirow[b]{2}{*}{0.0396} & \multirow[b]{2}{*}{2.96} \\
\hline & & & & & & & & & \\
\hline & $\mathrm{Mp}-2$ & 0.0230 & 0.0060 & 0.0504 & 0.442 & 0.0759 & 0.0148 & 0.0436 & 5.03 \\
\hline & $\mathrm{Mp}-3$ & 0.0523 & 0.013 & 0.110 & 0.722 & 0.128 & 0.0273 & 0.100 & 8.01 \\
\hline & $\mathrm{Mp}-4$ & 0.132 & 0.020 & 0.171 & 1.48 & 0.198 & 0.0432 & 0.155 & 13.5 \\
\hline & Mp-5 & 0.103 & 0.021 & 0.194 & 1.29 & 0.226 & 0.0460 & 0.172 & 16.1 \\
\hline & Mp-6 & 0.080 & 0.017 & 0.130 & 1.19 & 0.190 & 0.0421 & 0.120 & 14.7 \\
\hline & $\mathrm{Mp}-7$ & 0.150 & 0.032 & 0.282 & 2.23 & 0.299 & 0.0598 & 0.261 & 21.6 \\
\hline & $\mathrm{Mp}-8$ & 0.134 & 0.037 & 0.313 & 1.91 & 0.360 & 0.0711 & 0.289 & 24.5 \\
\hline & Mp-9 & 0.207 & 0.036 & 0.286 & 2.73 & 0.370 & 0.0778 & 0.259 & 32.0 \\
\hline & $\mathrm{Mp}-10$ & 0.227 & 0.042 & 0.330 & 3.29 & 0.443 & 0.0895 & 0.317 & 31.8 \\
\hline & Mp-11 & 0.723 & 0.092 & 0.782 & 6.83 & 0.870 & 0.179 & 0.727 & 59.4 \\
\hline & Mp-12 & 0.454 & 0.082 & 0.773 & 5.11 & 0.950 & 0.235 & 0.685 & 25.0 \\
\hline
\end{tabular}




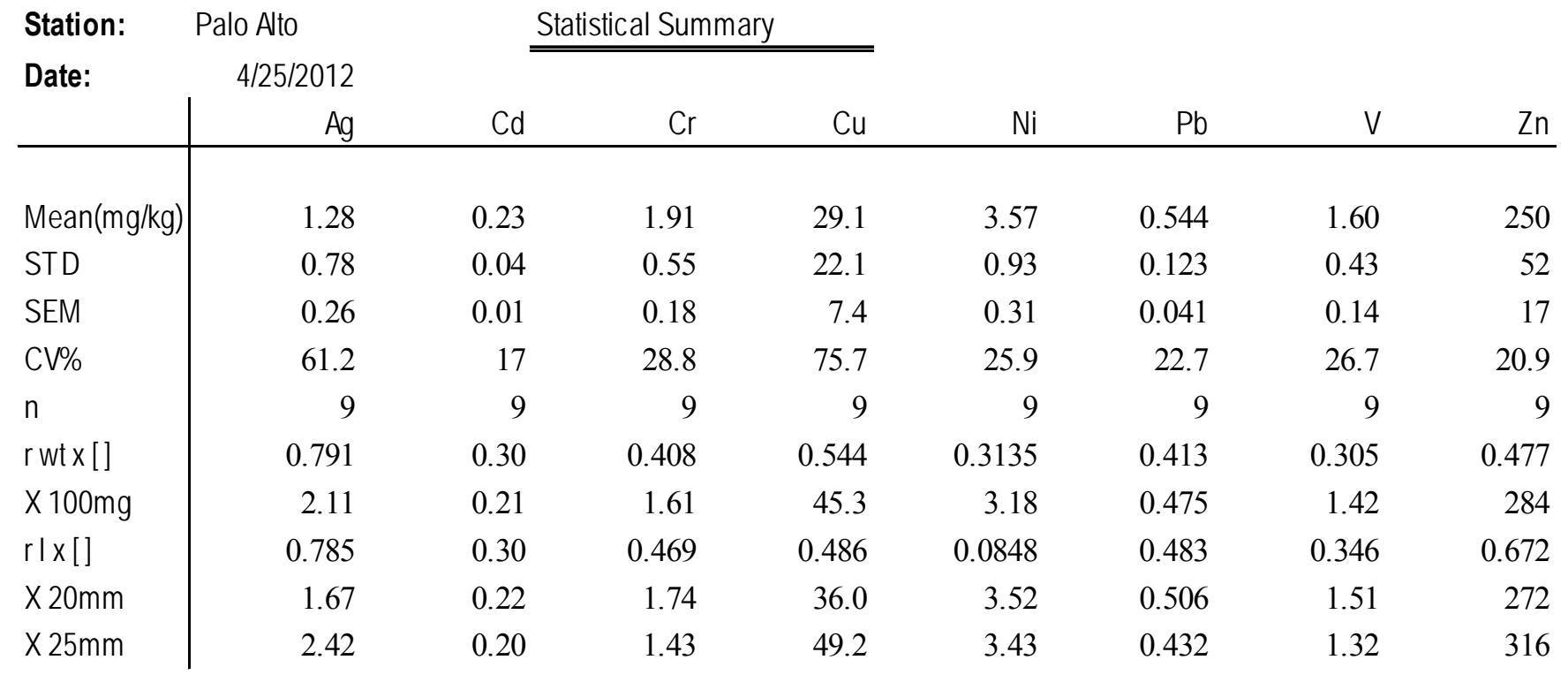

Estimated content (ug) for $15 \mathrm{~mm}$ and $20 \mathrm{~mm}$ clam

\begin{tabular}{|c|c|c|c|c|c|c|c|c|}
\hline & $\mathrm{Ag}$ & $\mathrm{Cd}$ & $\mathrm{Cr}$ & $\mathrm{Cu}$ & $\mathrm{Ni}$ & $\mathrm{Pb}$ & V & $\mathrm{Zn}$ \\
\hline $20 \mathrm{~mm}$ & 0.116 & 0.017 & 0.128 & 2.31 & 0.257 & 0.0382 & 0.111 & 20.5 \\
\hline $25 \mathrm{~mm}$ & 0.330 & 0.029 & 0.207 & 5.43 & 0.449 & 0.0641 & 0.188 & 42.3 \\
\hline
\end{tabular}

$\begin{array}{rr}0.035 \mathrm{gm} & 0.076 \mathrm{gm} \\ 35 \mathrm{mg} & 76 \mathrm{mg}\end{array}$

Estimated weight for $25 \mathrm{~mm}$ clam

$0.140 \mathrm{gm}$

$140 \mathrm{mg}$ 


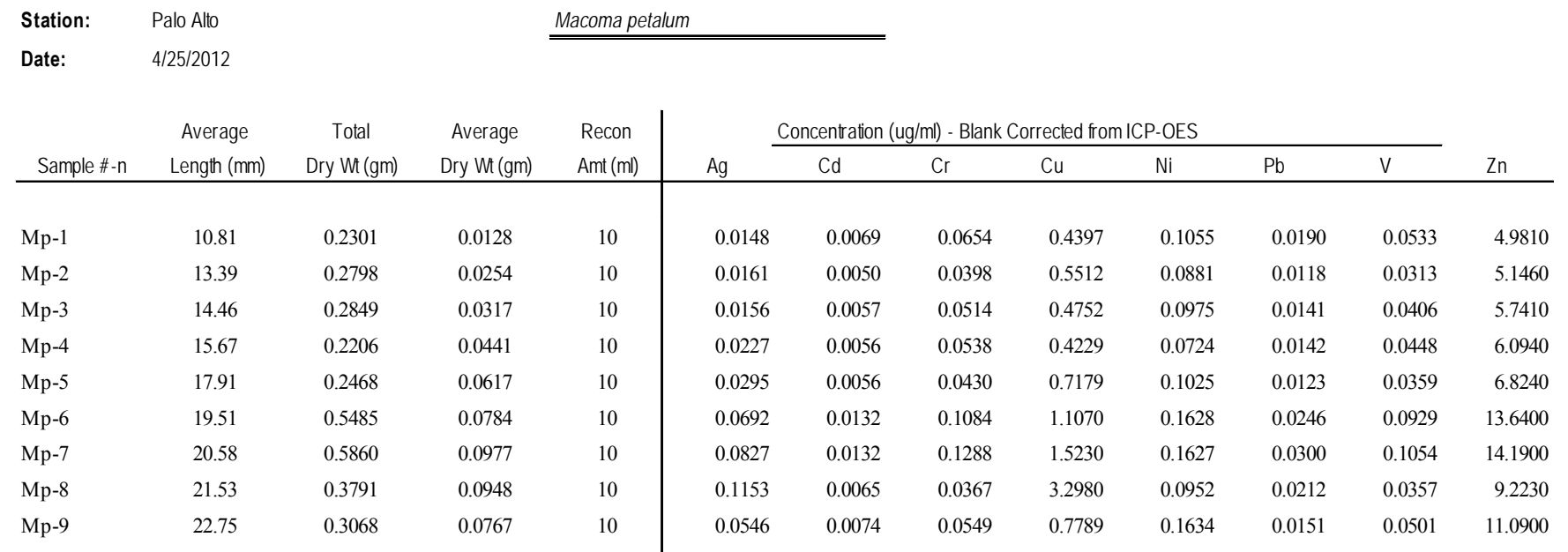

\begin{tabular}{lllllllll} 
MDL & 0.0005 & 0.0002 & 0.0019 & 0.0012 & 0.0003 & 0.0022 & 0.0003 & 0.0036 \\
MRL & 0.0010 & 0.0004 & 0.0037 & 0.0025 & 0.0007 & 0.0044 & 0.0007 & 0.0071 \\
& & & & & & & & \\
Sample \# & & & & & & & \\
\hline
\end{tabular}

\begin{tabular}{|c|c|c|c|c|c|c|c|c|c|}
\hline Concentration $(\mathrm{ug} / \mathrm{g})==>$ & Mp-1 & 0.643 & 0.30 & 2.84 & 19.1 & 4.58 & 0.826 & 2.32 & 216 \\
\hline & Mp-2 & 0.575 & 0.18 & 1.42 & 19.7 & 3.15 & 0.422 & 1.12 & 184 \\
\hline & Mp-3 & 0.548 & 0.20 & 1.80 & 16.7 & 3.42 & 0.495 & 1.43 & 202 \\
\hline & Mp-4 & 1.03 & 0.25 & 2.44 & 19.2 & 3.28 & 0.644 & 2.03 & 276 \\
\hline & Mp-5 & 1.20 & 0.23 & 1.74 & 29.1 & 4.15 & 0.498 & 1.45 & 276 \\
\hline & Mp-6 & 1.26 & 0.24 & 1.98 & 20.2 & 2.97 & 0.448 & 1.69 & 249 \\
\hline & Мp-7 & 1.41 & 0.23 & 2.20 & 26.0 & 2.78 & 0.512 & 1.80 & 242 \\
\hline & Mp-8 & 3.04 & 0.17 & 0.968 & 87.0 & 2.51 & 0.559 & 0.942 & 243 \\
\hline & Мp-9 & 1.78 & 0.24 & 1.79 & 25.4 & 5.33 & 0.492 & 1.63 & 361 \\
\hline \multirow{10}{*}{ Content (ug) ==> } & Sample \# & & & & & & & & \\
\hline & Mp-1 & 0.00822 & 0.0038 & 0.0363 & 0.244 & 0.0586 & 0.0106 & 0.0296 & 2.77 \\
\hline & Mp-2 & 0.0146 & 0.0045 & 0.0362 & 0.501 & 0.0801 & 0.0107 & 0.0285 & 4.68 \\
\hline & Mp-3 & 0.0173 & 0.0063 & 0.0571 & 0.528 & 0.108 & 0.0157 & 0.0451 & 6.38 \\
\hline & Mp-4 & 0.0454 & 0.011 & 0.108 & 0.846 & 0.145 & 0.0284 & 0.0896 & 12.2 \\
\hline & Mp-5 & 0.0738 & 0.014 & 0.108 & 1.79 & 0.256 & 0.0308 & 0.0898 & 17.1 \\
\hline & Mp-6 & 0.0989 & 0.019 & 0.155 & 1.58 & 0.233 & 0.0351 & 0.133 & 19.5 \\
\hline & Mp-7 & 0.138 & 0.022 & 0.215 & 2.54 & 0.271 & 0.0500 & 0.176 & 23.7 \\
\hline & Mp-8 & 0.288 & 0.016 & 0.0918 & 8.25 & 0.238 & 0.0530 & 0.089 & 23.1 \\
\hline & Мp-9 & 0.137 & 0.019 & 0.137 & 1.95 & 0.409 & 0.0378 & 0.125 & 27.7 \\
\hline
\end{tabular}




\begin{tabular}{|c|c|c|c|c|c|c|c|c|}
\hline \multirow{3}{*}{$\begin{array}{l}\text { Station: } \\
\text { Date: }\end{array}$} & \multirow{2}{*}{$\begin{array}{l}\text { Palo Alto } \\
5 / 14 / 2012\end{array}$} & \multicolumn{3}{|c|}{ Statistical Summary } & \multirow[b]{3}{*}{$\mathrm{Ni}$} & \multirow[b]{3}{*}{$\mathrm{Pb}$} & \multirow[b]{3}{*}{ V } & \multirow[b]{3}{*}{$\mathrm{Zn}$} \\
\hline & & & & & & & & \\
\hline & $\mathrm{Ag}$ & $\mathrm{Cd}$ & $\mathrm{Cr}$ & $\mathrm{Cu}$ & & & & \\
\hline Mean $(\mathrm{mg} / \mathrm{kg})$ & 0.838 & 0.17 & 1.22 & 15.5 & 2.64 & 0.598 & 1.09 & 193 \\
\hline STD & 0.515 & 0.06 & 0.68 & 2.6 & 0.56 & 0.216 & 0.59 & 36 \\
\hline SEM & 0.149 & 0.02 & 0.20 & 0.8 & 0.16 & 0.062 & 0.17 & 10 \\
\hline $\mathrm{CV} \%$ & 61.5 & 38 & 55.5 & 16.9 & 21.4 & 36.1 & 54.5 & 18.4 \\
\hline$n$ & 12 & 12 & 12 & 12 & 12 & 12 & 12 & 12 \\
\hline rwtx [] & 0.879 & 0.39 & 0.316 & 0.546 & 0.392 & 0.712 & 0.256 & 0.307 \\
\hline X100mg & 0.94 & 0.16 & 1.18 & 15.8 & 2.59 & 0.563 & 1.05 & 196 \\
\hline $\operatorname{rlx}[]$ & 0.906 & 0.34 & 0.257 & 0.645 & 0.331 & 0.734 & 0.177 & 0.403 \\
\hline X 20mm & 0.99 & 0.16 & 1.17 & 16.0 & 2.58 & 0.544 & 1.05 & 198 \\
\hline$\times 25 \mathrm{~mm}$ & 1.54 & 0.13 & 0.96 & 18.0 & 2.36 & 0.360 & 0.931 & 215 \\
\hline
\end{tabular}

Estimated content (ug) for $15 \mathrm{~mm}$ and $20 \mathrm{~mm}$ clam

\begin{tabular}{|c|c|c|c|c|c|c|c|c|}
\hline & $\mathrm{Ag}$ & $\mathrm{Cd}$ & $\mathrm{Cr}$ & $\mathrm{Cu}$ & $\mathrm{Ni}$ & $\mathrm{Pb}$ & V & $\mathrm{Zn}$ \\
\hline $20 \mathrm{~mm}$ & 0.0851 & 0.014 & 0.0968 & 1.51 & 0.237 & 0.0474 & 0.0886 & 18.6 \\
\hline $25 \mathrm{~mm}$ & 0.291 & 0.024 & 0.162 & 3.33 & 0.439 & 0.0729 & 0.155 & 39.7 \\
\hline
\end{tabular}

$\begin{array}{rr}0.039 \mathrm{gm} & 0.094 \mathrm{gm} \\ 39 \mathrm{mg} & 94 \mathrm{mg}\end{array}$

Estimated weight for $25 \mathrm{~mm}$ clam

$0.188 \mathrm{gm}$

$188 \mathrm{mg}$ 


\begin{tabular}{|c|c|c|c|c|c|c|c|c|c|c|c|c|}
\hline Station: & Palo Alto & & & Macoma pe & & & & & & & & \\
\hline & Average & Total & Average & Recon & & centration & ml) - Blank & rrected fron & P-OES & & & \\
\hline Sample \#-n & Length (mm) & Dry Wt (gm) & Dry Wt (gm) & Amt (ml) & $\mathrm{Ag}$ & $\mathrm{Cd}$ & $\mathrm{Cr}$ & $\mathrm{Cu}$ & $\mathrm{Ni}$ & $\mathrm{Pb}$ & V & $\mathrm{Zn}$ \\
\hline Mp-1 & 12.02 & 0.1804 & 0.0180 & 10 & 0.0058 & 0.0041 & 0.0304 & 0.2271 & 0.0538 & 0.0175 & 0.0236 & 3.4210 \\
\hline Mp-3 & 14.62 & 0.3526 & 0.0392 & 10 & 0.0139 & 0.0058 & 0.0415 & 0.5139 & 0.0972 & 0.0247 & 0.0349 & 5.8190 \\
\hline $\mathrm{Mp}-4$ & 15.43 & 0.4579 & 0.0416 & 10 & 0.0225 & 0.0080 & 0.0585 & 0.6398 & 0.1176 & 0.0293 & 0.0527 & 7.7260 \\
\hline Mp-5 & 16.56 & 0.5053 & 0.0561 & 10 & 0.0222 & 0.0061 & 0.0399 & 0.7061 & 0.1018 & 0.0245 & 0.0361 & 7.3080 \\
\hline Mp-6 & 17.57 & 0.3009 & 0.0602 & 10 & 0.0155 & 0.0051 & 0.0342 & 0.4727 & 0.0874 & 0.0190 & 0.0323 & 5.8180 \\
\hline Mp-7 & 19.49 & 0.7454 & 0.0828 & 15 & 0.0513 & 0.0066 & 0.0423 & 0.8760 & 0.1160 & 0.0208 & 0.0409 & 11.2600 \\
\hline Mp-8 & 20.40 & 0.2802 & 0.0934 & 10 & 0.0394 & 0.0093 & 0.0883 & 0.5250 & 0.1118 & 0.0244 & 0.0795 & 7.9700 \\
\hline Mp-10 & 22.25 & 0.3007 & 0.1504 & 10 & 0.0251 & 0.0030 & 0.0232 & 0.3581 & 0.0618 & 0.0097 & 0.0199 & 5.6530 \\
\hline Mp-11 & 23.50 & 0.4796 & 0.1599 & 10 & 0.0634 & 0.0067 & 0.0379 & 0.9577 & 0.0980 & 0.0221 & 0.0373 & 9.6360 \\
\hline $\mathrm{Mp}-12$ & 25.98 & 0.3991 & 0.1996 & 10 & 0.0769 & 0.0047 & 0.0314 & 0.7208 & 0.0962 & 0.0158 & 0.0292 & 8.1150 \\
\hline & & & & MDL & 0.0005 & 0.0002 & 0.0019 & 0.0012 & 0.0003 & 0.0022 & 0.0003 & 0.0036 \\
\hline & & & & $\mathrm{MRL}$ & 0.0010 & 0.0004 & 0.0037 & 0.0025 & 0.0007 & 0.0044 & 0.0007 & 0.0071 \\
\hline & & & & Sample \# & & & & & & & & \\
\hline & & Concentration & $g / g)==>$ & $\mathrm{Mp}-1$ & 0.322 & 0.23 & 1.69 & 12.6 & 2.98 & 0.970 & 1.31 & 190 \\
\hline & & & & $\mathrm{Mp}-2$ & 0.336 & 0.19 & 1.46 & 12.9 & 3.10 & 0.866 & 1.24 & 172 \\
\hline & & & & $\mathrm{Mp}-3$ & 0.394 & 0.16 & 1.18 & 14.6 & 2.76 & 0.701 & 0.990 & 165 \\
\hline & & & & Mp-4 & 0.491 & 0.17 & 1.28 & 14.0 & 2.57 & 0.640 & 1.15 & 169 \\
\hline & & & & Mp-5 & 0.439 & 0.12 & 0.790 & 14.0 & 2.01 & 0.485 & 0.714 & 145 \\
\hline & & & & Mp-6 & 0.515 & 0.17 & 1.14 & 15.7 & 2.90 & 0.631 & 1.07 & 193 \\
\hline & & & & $\mathrm{Mp}-7$ & 1.03 & 0.13 & 0.851 & 17.6 & 2.33 & 0.419 & 0.823 & 227 \\
\hline & & & & Mp-8 & 1.41 & 0.33 & 3.15 & 18.7 & 3.99 & 0.871 & 2.84 & 284 \\
\hline & & & & Mp-9 & 1.03 & 0.12 & 0.809 & 15.7 & 2.50 & 0.413 & 0.751 & 183 \\
\hline & & & & Mp-10 & 0.835 & 0.10 & 0.772 & 11.9 & 2.06 & 0.323 & 0.662 & 188 \\
\hline & & & & Mp-11 & 1.32 & 0.14 & 0.790 & 20.0 & 2.04 & 0.461 & 0.778 & 201 \\
\hline & & & & Mp-12 & 1.93 & 0.12 & 0.787 & 18.1 & 2.41 & 0.396 & 0.732 & 203 \\
\hline & & & & Sample \# & & & & & & & & \\
\hline & & Content ( & $=\Rightarrow$ & Mp-1 & 0.00580 & 0.0041 & 0.0304 & 0.227 & 0.0538 & 0.0175 & 0.0236 & 3.42 \\
\hline & & & & $\mathrm{Mp}-2$ & 0.00975 & 0.0054 & 0.0425 & 0.376 & 0.0900 & 0.0251 & 0.0361 & 5.00 \\
\hline & & & & $\mathrm{Mp}-3$ & 0.0154 & 0.0064 & 0.0461 & 0.571 & 0.108 & 0.0274 & 0.0388 & 6.47 \\
\hline & & & & $\mathrm{Mp}-4$ & 0.0205 & 0.0073 & 0.0532 & 0.582 & 0.107 & 0.0266 & 0.0479 & 7.02 \\
\hline & & & & $\mathrm{Mp}-5$ & 0.0247 & 0.0068 & 0.0443 & 0.785 & 0.113 & 0.0272 & 0.0401 & 8.12 \\
\hline & & & & Mp-6 & 0.0310 & 0.010 & 0.0684 & 0.945 & 0.175 & 0.0380 & 0.0646 & 11.6 \\
\hline & & & & $\mathrm{Mp}-7$ & 0.0855 & 0.011 & 0.0705 & 1.46 & 0.193 & 0.0347 & 0.0682 & 18.8 \\
\hline & & & & Mp-8 & 0.131 & 0.031 & 0.294 & 1.75 & 0.373 & 0.0813 & 0.265 & 26.6 \\
\hline & & & & Mp-9 & 0.117 & 0.014 & 0.0915 & 1.78 & 0.283 & 0.0468 & 0.0850 & 20.7 \\
\hline & & & & Mp-10 & 0.126 & 0.015 & 0.116 & 1.79 & 0.309 & 0.0485 & 0.0995 & 28.3 \\
\hline & & & & Mp-11 & 0.211 & 0.022 & 0.126 & 3.19 & 0.327 & 0.0737 & 0.124 & 32.1 \\
\hline & & & & $\mathrm{Mp}-12$ & 0.385 & 0.024 & 0.157 & 3.60 & 0.481 & 0.0790 & 0.146 & 40.6 \\
\hline
\end{tabular}




\begin{tabular}{|c|c|c|c|c|c|c|c|c|}
\hline \multirow{3}{*}{$\begin{array}{l}\text { Station: } \\
\text { Date: }\end{array}$} & \multirow{2}{*}{$\begin{array}{l}\text { Palo Alto } \\
6 / 5 / 2012\end{array}$} & \multicolumn{3}{|c|}{ Statistical Summary } & \multirow[b]{3}{*}{$\mathrm{Ni}$} & \multirow[b]{3}{*}{$\mathrm{Pb}$} & \multirow[b]{3}{*}{$\mathrm{V}$} & \multirow[b]{3}{*}{$\mathrm{Zn}$} \\
\hline & & & & & & & & \\
\hline & $\mathrm{Ag}$ & $\mathrm{Cd}$ & $\mathrm{Cr}$ & $\mathrm{Cu}$ & & & & \\
\hline $\operatorname{Mean}(\mathrm{mg} / \mathrm{kg})$ & 0.952 & 0.17 & 1.39 & 17.1 & 2.87 & 0.695 & 1.20 & 185 \\
\hline STD & 0.818 & 0.04 & 0.45 & 3.9 & 0.65 & 0.178 & 0.38 & 45 \\
\hline SEM & 0.236 & 0.01 & 0.13 & 1.1 & 0.19 & 0.052 & 0.11 & 13 \\
\hline CV\% & 85.9 & 24 & 32.5 & 23.0 & 22.5 & 25.7 & 31.8 & 24.4 \\
\hline $\mathrm{n}$ & 12 & 12 & 12 & 12 & 12 & 12 & 12 & 12 \\
\hline rwtx [] & 0.838 & 0.28 & 0.067 & 0.500 & 0.266 & 0.432 & 0.014 & 0.658 \\
\hline X100mg & 1.13 & 0.16 & 1.378 & 17.6 & 2.92 & 0.675 & 1.19 & 193 \\
\hline $\mathrm{rlx}[]$ & 0.813 & 0.38 & 0.174 & 0.510 & 0.194 & 0.575 & 0.078 & 0.539 \\
\hline$\times 20 \mathrm{~mm}$ & 1.18 & 0.16 & 1.36 & 17.7 & 2.92 & 0.660 & 1.19 & 194 \\
\hline$\times 25 \mathrm{~mm}$ & 1.90 & 0.15 & 1.275 & 19.9 & 3.05 & 0.549 & 1.153 & 220 \\
\hline
\end{tabular}

Estimated content (ug) for $15 \mathrm{~mm}$ and $20 \mathrm{~mm}$ clam

\begin{tabular}{lrrrrrrrr} 
& $\mathrm{Ag}$ & $\mathrm{Cd}$ & $\mathrm{Cr}$ & $\mathrm{Cu}$ & $\mathrm{Ni}$ & $\mathrm{Pb}$ & $\mathrm{V}$ & $\mathrm{Zn}$ \\
\cline { 2 - 8 } & & & & & & & & \\
$20 \mathrm{~mm}$ & 0.0861 & 0.014 & 0.116 & 1.56 & 0.255 & 0.0570 & 0.102 & 17.0 \\
$25 \mathrm{~mm}$ & 0.273 & 0.027 & 0.225 & 3.41 & 0.528 & 0.102 & 0.201 & 37.6
\end{tabular}

$\begin{array}{rr}0.036 \mathrm{gm} & 0.090 \mathrm{gm} \\ 36 \mathrm{mg} & 90 \mathrm{mg}\end{array}$

Estimated weight for $25 \mathrm{~mm}$ clam

$0.184 \mathrm{gm}$

$184 \mathrm{mg}$ 


\begin{tabular}{|c|c|c|c|c|c|c|c|c|c|c|c|c|}
\hline \multirow{2}{*}{$\begin{array}{l}\text { Station: } \\
\text { Date: }\end{array}$} & \multicolumn{3}{|l|}{$\begin{array}{l}\text { Palo Alto } \\
6 / 5 / 2012\end{array}$} & \multicolumn{3}{|c|}{ Macoma petalum } & & \multirow[b]{3}{*}{$\mathrm{Pb}$} & \multirow[b]{3}{*}{$\mathrm{V}$} & \multirow[b]{3}{*}{$\mathrm{Zn}$} \\
\hline & Average & Total & Average & \multirow{2}{*}{$\begin{array}{l}\text { Recon } \\
\text { Amt (ml) }\end{array}$} & \multirow[b]{2}{*}{$\mathrm{Ag}$} & Concentration (ug/ml) - Blank Corrected from ICP-OES & & & & & & \\
\hline Sample \#-n & Length (mm) & Dry Wt (gm) & Dry Wt (gm) & & & $\mathrm{Cd}$ & $\mathrm{Cr}$ & $\mathrm{Cu}$ & $\mathrm{Ni}$ & & & \\
\hline Mp-1 & 11.23 & 0.1620 & 0.0135 & 10 & 0.0082 & 0.0044 & 0.0403 & 0.2877 & 0.0656 & 0.0179 & 0.0332 & 3.1900 \\
\hline Mp-2 & 13.63 & 0.2935 & 0.0245 & 10 & 0.0146 & 0.0046 & 0.0348 & 0.4246 & 0.0833 & 0.0278 & 0.0292 & 5.1420 \\
\hline Mp-3 & 14.39 & 0.5141 & 0.0302 & 10 & 0.0263 & 0.0082 & 0.0615 & 0.7892 & 0.1314 & 0.0363 & 0.0514 & 8.1290 \\
\hline Mp-4 & 15.53 & 0.6167 & 0.0363 & 10 & 0.0295 & 0.0109 & 0.0857 & 0.9699 & 0.1553 & 0.0387 & 0.0708 & 9.6810 \\
\hline Mp-5 & 16.54 & 0.7619 & 0.0635 & 10 & 0.0470 & 0.0114 & 0.0825 & 1.2070 & 0.1684 & 0.0426 & 0.0696 & 11.3500 \\
\hline Mp-6 & 17.37 & 0.4337 & 0.0620 & 10 & 0.0194 & 0.0062 & 0.0427 & 0.6264 & 0.1133 & 0.0293 & 0.0364 & 8.2640 \\
\hline Mp-7 & 18.45 & 0.4557 & 0.0570 & 10 & 0.0265 & 0.0089 & 0.0765 & 0.7615 & 0.1303 & 0.0297 & 0.0701 & 6.6500 \\
\hline Mp-8 & 19.39 & 0.3792 & 0.0948 & 10 & 0.0305 & 0.0059 & 0.0570 & 0.6779 & 0.0980 & 0.0274 & 0.0505 & 5.7540 \\
\hline Mp-9 & 20.49 & 0.3958 & 0.0990 & 10 & 0.0497 & 0.0051 & 0.0364 & 0.7904 & 0.0930 & 0.0207 & 0.0340 & 8.9090 \\
\hline Mp-10 & 22.81 & 0.2658 & 0.1329 & 10 & 0.0192 & 0.0031 & 0.0247 & 0.3129 & 0.0708 & 0.0118 & 0.0225 & 3.7710 \\
\hline Mp-11 & 23.72 & 0.1930 & 0.1930 & 10 & 0.0342 & 0.0033 & 0.0292 & 0.3316 & 0.0564 & 0.0133 & 0.0228 & 5.0960 \\
\hline Mp-12 & 27.39 & 0.1956 & 0.1956 & 10 & 0.0632 & 0.0036 & 0.0345 & 0.5401 & 0.0843 & 0.0135 & 0.0321 & 5.2580 \\
\hline & & & & MDL & 0.0005 & 0.0002 & 0.0019 & 0.0012 & 0.0003 & 0.0022 & 0.0003 & 0.0036 \\
\hline & & & & MRL & 0.0010 & 0.0004 & 0.0037 & 0.0025 & 0.0007 & 0.0044 & 0.0007 & 0.0071 \\
\hline & & & & Sample \# & & & & & & & & \\
\hline & & Concentration & (g) $==>$ & Mp-1 & 0.506 & 0.27 & 2.49 & 17.8 & 4.05 & 1.10 & 2.05 & 197 \\
\hline & & & & Mp-2 & 0.497 & 0.16 & 1.19 & 14.5 & 2.84 & 0.947 & 0.995 & 175 \\
\hline & & & & Mp-3 & 0.512 & 0.16 & 1.20 & 15.4 & 2.56 & 0.706 & 1.000 & 158 \\
\hline & & & & Mp-4 & 0.478 & 0.18 & 1.39 & 15.7 & 2.52 & 0.628 & 1.15 & 157 \\
\hline & & & & Mp-5 & 0.617 & 0.15 & 1.08 & 15.8 & 2.21 & 0.559 & 0.914 & 149 \\
\hline & & & & Mp-6 & 0.447 & 0.14 & 0.98 & 14.4 & 2.61 & 0.676 & 0.839 & 191 \\
\hline & & & & Mp-7 & 0.582 & 0.20 & 1.68 & 16.7 & 2.86 & 0.652 & 1.54 & 146 \\
\hline & & & & Mp-8 & 0.804 & 0.16 & 1.50 & 17.9 & 2.58 & 0.723 & 1.33 & 152 \\
\hline & & & & Mp-9 & 1.26 & 0.13 & 0.920 & 20.0 & 2.35 & 0.523 & 0.859 & 225 \\
\hline & & & & Mp-10 & 0.722 & 0.12 & 0.929 & 11.8 & 2.66 & 0.444 & 0.847 & 142 \\
\hline & & & & Mp-11 & 1.77 & 0.17 & 1.51 & 17.2 & 2.92 & 0.689 & 1.18 & 264 \\
\hline & & & & Mp-12 & 3.23 & 0.18 & 1.76 & 27.6 & 4.31 & 0.690 & 1.64 & 269 \\
\hline & & & & Sample \# & & & & & & & & \\
\hline & & Content ( & $==>$ & Mp-1 & 0.00683 & 0.0037 & 0.0336 & 0.240 & 0.0547 & 0.0149 & 0.0277 & 2.66 \\
\hline & & & & $\mathrm{Mp}-2$ & 0.0122 & 0.0038 & 0.0290 & 0.354 & 0.0694 & 0.0232 & 0.0243 & 4.29 \\
\hline & & & & Mp-3 & 0.0155 & 0.0048 & 0.0362 & 0.464 & 0.0773 & 0.0214 & 0.0302 & 4.78 \\
\hline & & & & $\mathrm{Mp}-4$ & 0.0174 & 0.0064 & 0.0504 & 0.571 & 0.0914 & 0.0228 & 0.0416 & 5.69 \\
\hline & & & & Mp-5 & 0.0392 & 0.0095 & 0.0688 & 1.01 & 0.140 & 0.0355 & 0.0580 & 9.46 \\
\hline & & & & Mp-6 & 0.0277 & 0.0089 & 0.0610 & 0.895 & 0.162 & 0.0419 & 0.0520 & 11.8 \\
\hline & & & & Mp-7 & 0.0331 & 0.011 & 0.0956 & 0.952 & 0.163 & 0.0371 & 0.0876 & 8.31 \\
\hline & & & & Mp-8 & 0.0763 & 0.015 & 0.143 & 1.69 & 0.245 & 0.0685 & 0.126 & 14.4 \\
\hline & & & & Mp-9 & 0.124 & 0.013 & 0.0910 & 1.98 & 0.233 & 0.0518 & 0.085 & 22.3 \\
\hline & & & & Mp-10 & 0.0960 & 0.016 & 0.124 & 1.56 & 0.354 & 0.0590 & 0.113 & 18.9 \\
\hline & & & & Mp-11 & 0.342 & 0.033 & 0.292 & 3.32 & 0.564 & 0.133 & 0.228 & 51.0 \\
\hline & & & & Mp-12 & 0.632 & 0.036 & 0.345 & 5.40 & 0.843 & 0.135 & 0.321 & 52.6 \\
\hline
\end{tabular}




\begin{tabular}{|c|c|c|c|c|c|c|c|c|}
\hline \multirow{3}{*}{$\begin{array}{l}\text { Station: } \\
\text { Date: }\end{array}$} & \multirow{2}{*}{$\begin{array}{l}\text { Palo Alto } \\
\text { 9/17/2012 }\end{array}$} & \multicolumn{3}{|c|}{ Statistical Summary } & \multirow[b]{3}{*}{$\mathrm{Ni}$} & \multirow[b]{3}{*}{$\mathrm{Pb}$} & \multirow[b]{3}{*}{ V } & \multirow[b]{3}{*}{$\mathrm{Zn}$} \\
\hline & & & & & & & & \\
\hline & $\mathrm{Ag}$ & $\mathrm{Cd}$ & $\mathrm{Cr}$ & $\mathrm{Cu}$ & & & & \\
\hline $\operatorname{Mean}(\mathrm{mg} / \mathrm{kg})$ & 2.71 & 0.23 & 1.72 & 38.7 & 3.80 & 0.869 & 1.50 & 218 \\
\hline STD & 1.14 & 0.06 & 0.54 & 8.2 & 1.00 & 0.233 & 0.38 & 31 \\
\hline SEM & 0.34 & 0.02 & 0.16 & 2.5 & 0.30 & 0.070 & 0.12 & 9 \\
\hline CV\% & 42.1 & 26 & 31.0 & 21 & 26 & 26.8 & 25.4 & 14.4 \\
\hline$n$ & 11 & 11 & 11 & 11 & 11 & 11 & 11 & 11 \\
\hline rwtx[] & 0.395 & 0.44 & 0.608 & 0.225 & 0.135 & 0.5872 & 0.290 & 0.283 \\
\hline X 100mg & 3.15 & 0.21 & 1.41 & 41 & 3.9 & 0.736 & 1.39 & 227 \\
\hline $\operatorname{rlx}[]$ & 0.278 & 0.61 & 0.703 & 0.073 & 0.006 & 0.717 & 0.469 & 0.154 \\
\hline$\times 20 \mathrm{~mm}$ & 2.81 & 0.22 & 1.61 & 38.9 & 3.81 & 0.818 & 1.45 & 220 \\
\hline$\times 25 \mathrm{~mm}$ & 3.15 & 0.18 & 1.21 & 40 & 3.8 & 0.642 & 1.259 & 225 \\
\hline
\end{tabular}

Estimated content (ug) for $15 \mathrm{~mm}$ and $20 \mathrm{~mm}$ clam

\begin{tabular}{|c|c|c|c|c|c|c|c|c|}
\hline & $\mathrm{Ag}$ & $\mathrm{Cd}$ & $\mathrm{Cr}$ & $\mathrm{Cu}$ & $\mathrm{Ni}$ & $\mathrm{Pb}$ & V & $\mathrm{Zn}$ \\
\hline $20 \mathrm{~mm}$ & 0.149 & 0.012 & 0.0886 & 2.19 & 0.211 & 0.0453 & 0.0810 & 12.6 \\
\hline $25 \mathrm{~mm}$ & 0.311 & 0.022 & 0.155 & 4.47 & 0.418 & 0.0802 & 0.152 & 26.2 \\
\hline
\end{tabular}

$\begin{array}{rr}0.023 \mathrm{gm} & 0.058 \mathrm{gm} \\ 23 \mathrm{mg} & 58 \mathrm{mg}\end{array}$

Estimated weight for $25 \mathrm{~mm}$ clam

$0.121 \mathrm{gm}$

$121 \mathrm{mg}$ 
Station: Palo Alto

Macoma petalum

Date: $\quad$ 9/17/2012

\begin{tabular}{|c|c|c|c|c|c|c|c|c|c|c|c|c|}
\hline \multirow[b]{2}{*}{ Sample \#-n } & \multirow{2}{*}{$\begin{array}{c}\text { Average } \\
\text { Length (mm) }\end{array}$} & \multirow{2}{*}{$\begin{array}{c}\text { Total } \\
\text { Dry Wt (gm) }\end{array}$} & \multirow{2}{*}{$\begin{array}{c}\text { Average } \\
\text { Dry Wt (gm) }\end{array}$} & \multirow{2}{*}{$\begin{array}{l}\text { Recon } \\
\text { Amt (ml) }\end{array}$} & \multirow[b]{2}{*}{$\mathrm{Ag}$} & \multicolumn{6}{|c|}{ Concentration $(\mathrm{ug} / \mathrm{ml})$ - Blank Corrected from ICP-OES } & \multirow[b]{2}{*}{$\mathrm{Zn}$} \\
\hline & & & & & & $\mathrm{Cd}$ & $\mathrm{Cr}$ & $\mathrm{Cu}$ & $\mathrm{Ni}$ & $\mathrm{Pb}$ & V & \\
\hline Mp-1 & 9.60 & 0.2053 & 0.0059 & 10 & 0.0696 & 0.0078 & 0.0590 & 0.9677 & 0.0973 & 0.0271 & 0.0492 & 4.5480 \\
\hline $\mathrm{Mp}-2$ & 14.52 & 0.2322 & 0.0194 & 10 & 0.0582 & 0.0059 & 0.0407 & 0.9500 & 0.0809 & 0.0244 & 0.0359 & 5.2180 \\
\hline Mp-3 & 15.39 & 0.1605 & 0.0268 & 10 & 0.0325 & 0.0035 & 0.0249 & 0.5058 & 0.0611 & 0.0154 & 0.0196 & 4.0500 \\
\hline Mp-4 & 16.40 & 0.1777 & 0.0254 & 10 & 0.0358 & 0.0046 & 0.0334 & 0.7662 & 0.0745 & 0.0180 & 0.0285 & 3.9330 \\
\hline Mp-5 & 17.42 & 0.1989 & 0.0332 & 10 & 0.0534 & 0.0045 & 0.0476 & 0.6565 & 0.0834 & 0.0170 & 0.0277 & 3.7270 \\
\hline Mp-6 & 18.54 & 0.1890 & 0.0378 & 10 & 0.0721 & 0.0050 & 0.0362 & 0.8058 & 0.0735 & 0.0190 & 0.0339 & 4.3060 \\
\hline Mp-7 & 19.81 & 0.3149 & 0.0630 & 10 & 0.0690 & 0.0056 & 0.0412 & 1.0720 & 0.0996 & 0.0201 & 0.0379 & 6.4860 \\
\hline Mp-8 & 20.69 & 0.4095 & 0.0683 & 10 & 0.0804 & 0.0080 & 0.0612 & 1.3150 & 0.1215 & 0.0255 & 0.0552 & 7.8880 \\
\hline Mp-9 & 21.52 & 0.3946 & 0.0789 & 10 & 0.0851 & 0.0071 & 0.0484 & 1.3980 & 0.1240 & 0.0257 & 0.0461 & 7.0490 \\
\hline Mp-10 & 22.72 & 0.5244 & 0.1049 & 10 & 0.0827 & 0.0081 & 0.0531 & 1.5570 & 0.1194 & 0.0292 & 0.0567 & 10.4900 \\
\hline Mp-11 & 27.51 & 0.3155 & 0.1578 & 10 & 0.1746 & 0.0082 & 0.0493 & 1.7870 & 0.1890 & 0.0281 & 0.0557 & 9.0980 \\
\hline
\end{tabular}

\begin{tabular}{l|llllllll} 
MDL & 0.0005 & 0.0002 & 0.0019 & 0.0012 & 0.0003 & 0.0022 & 0.0003 & 0.0036 \\
MRL & 0.0010 & 0.0004 & 0.0037 & 0.0025 & 0.0007 & 0.0044 & 0.0007 & 0.0071 \\
& & & & & & & & \\
Sample \# & & & & & & & & \\
\hline
\end{tabular}

\begin{tabular}{|c|c|c|c|c|c|c|c|c|c|}
\hline & Mp-3 & 2.02 & 0.22 & 1.55 & 31.5 & 3.81 & 0.960 & 1.22 & 252 \\
\hline & $\mathrm{Mp}-4$ & 2.01 & 0.26 & 1.88 & 43.1 & 4.19 & 1.01 & 1.60 & 221 \\
\hline & Mp-5 & 2.68 & 0.23 & 2.39 & 33.0 & 4.19 & 0.855 & 1.39 & 187 \\
\hline & Mp-6 & 3.81 & 0.26 & 1.92 & 42.6 & 3.89 & 1.01 & 1.79 & 228 \\
\hline & Mp-7 & 2.19 & 0.18 & 1.31 & 34.0 & 3.16 & 0.638 & 1.20 & 206 \\
\hline & Mp-8 & 1.96 & 0.20 & 1.49 & 32.1 & 2.97 & 0.623 & 1.35 & 193 \\
\hline & Mp-9 & 2.16 & 0.18 & 1.23 & 35.4 & 3.14 & 0.651 & 1.17 & 179 \\
\hline & Mp-10 & 1.58 & 0.15 & 1.01 & 29.7 & 2.28 & 0.557 & 1.08 & 200 \\
\hline & Mp-11 & 5.53 & 0.26 & 1.56 & 56.6 & 5.99 & 0.891 & 1.77 & 288 \\
\hline
\end{tabular}

\begin{tabular}{|c|c|c|c|c|c|c|c|c|c|}
\hline \multirow[b]{2}{*}{ Content (ug) $==>$} & \multicolumn{9}{|l|}{ Sample \# } \\
\hline & $\mathrm{Mp}-1$ & 0.0199 & 0.0022 & 0.0169 & 0.276 & 0.0278 & 0.0077 & 0.0141 & 1.30 \\
\hline & $\mathrm{Mp}-2$ & 0.0485 & 0.0049 & 0.0339 & 0.792 & 0.0674 & 0.0203 & 0.0299 & 4.35 \\
\hline & $\mathrm{Mp}-3$ & 0.0542 & 0.0058 & 0.0415 & 0.843 & 0.102 & 0.0257 & 0.0327 & 6.75 \\
\hline & $\mathrm{Mp}-5$ & 0.0890 & 0.0075 & 0.0793 & 1.09 & 0.139 & 0.0283 & 0.0462 & 6.21 \\
\hline & Mp-6 & 0.144 & 0.010 & 0.0724 & 1.61 & 0.147 & 0.0380 & 0.0678 & 8.61 \\
\hline & $\mathrm{Mp}-7$ & 0.138 & 0.011 & 0.0824 & 2.14 & 0.199 & 0.0402 & 0.0758 & 13.0 \\
\hline & Mp-9 & 0.170 & 0.014 & 0.0968 & 2.80 & 0.248 & 0.0514 & 0.0922 & 14.1 \\
\hline & Mp-10 & 0.165 & 0.016 & 0.106 & 3.11 & 0.239 & 0.0584 & 0.113 & 21.0 \\
\hline & $\mathrm{Mp}-11$ & 0.873 & 0.041 & 0.247 & 8.94 & 0.945 & 0.141 & 0.279 & 45.5 \\
\hline
\end{tabular}




\begin{tabular}{|c|c|c|c|c|c|c|c|c|}
\hline \multirow{3}{*}{$\begin{array}{l}\text { Station: } \\
\text { Date: }\end{array}$} & \multirow{2}{*}{$\begin{array}{l}\text { Palo Alto } \\
10 / 24 / 2012\end{array}$} & \multicolumn{3}{|c|}{ Statistical Summary } & \multirow[b]{3}{*}{$\mathrm{Ni}$} & \multirow[b]{3}{*}{$\mathrm{Pb}$} & \multirow[b]{3}{*}{$\mathrm{V}$} & \multirow[b]{3}{*}{$\mathrm{Zn}$} \\
\hline & & & & & & & & \\
\hline & $\mathrm{Ag}$ & $\mathrm{Cd}$ & $\mathrm{Cr}$ & $\mathrm{Cu}$ & & & & \\
\hline $\operatorname{Mean}(\mathrm{mg} / \mathrm{kg})$ & 3.62 & 0.31 & 2.09 & 43.7 & 4.37 & 0.96 & 1.96 & 251 \\
\hline STD & 1.00 & 0.08 & 0.79 & 9.2 & 1.05 & 0.24 & 0.41 & 106 \\
\hline SEM & 0.28 & 0.02 & 0.22 & 2.5 & 0.29 & 0.07 & 0.11 & 29 \\
\hline CV\% & 27.6 & 25 & 37.8 & 21.0 & 24.0 & 25.0 & 20.8 & 42.3 \\
\hline$n$ & 13 & 13 & 13 & 13 & 13 & 13 & 13 & 13 \\
\hline rwtx[] & 0.045 & 0.09 & 0.228 & 0.006 & 0.043 & 0.452 & 0.077 & 0.146 \\
\hline X 100mg & 3.69 & 0.30 & 2.37 & 43.8 & 4.44 & 0.789 & 2.01 & 275 \\
\hline$r \mid x[]$ & 0.113 & 0.19 & 0.192 & 0.101 & 0.054 & 0.563 & 0.013 & 0.073 \\
\hline$\times 20 \mathrm{~mm}$ & 3.59 & 0.31 & 2.13 & 43.4 & 4.35 & 0.92 & 1.96 & 253 \\
\hline $\mathrm{X} 25 \mathrm{~mm}$ & 3.46 & 0.29 & 2.30 & 42.4 & 4.29 & 0.773 & 1.95 & 261 \\
\hline
\end{tabular}

Estimated content (ug) for $15 \mathrm{~mm}$ and $20 \mathrm{~mm}$ clam

\begin{tabular}{lrrrrrrrr} 
& $\mathrm{Ag}$ & $\mathrm{Cd}$ & $\mathrm{Cr}$ & $\mathrm{Cu}$ & $\mathrm{Ni}$ & $\mathrm{Pb}$ & $\mathrm{V}$ & $\mathrm{Zn}$ \\
\cline { 2 - 8 } & & & & & & & & \\
$20 \mathrm{~mm}$ & 0.176 & 0.015 & 0.103 & 2.18 & 0.217 & 0.0457 & 0.0983 & 11.8 \\
$25 \mathrm{~mm}$ & 0.346 & 0.029 & 0.213 & 4.33 & 0.430 & 0.0829 & 0.198 & 23.1
\end{tabular}

$0.021 \mathrm{gm}$

$21 \mathrm{mg}$
$0.052 \mathrm{gm}$

$52 \mathrm{mg}$

Estimated weight for $25 \mathrm{~mm}$ clam

$0.105 \mathrm{gm}$

$105 \mathrm{mg}$ 


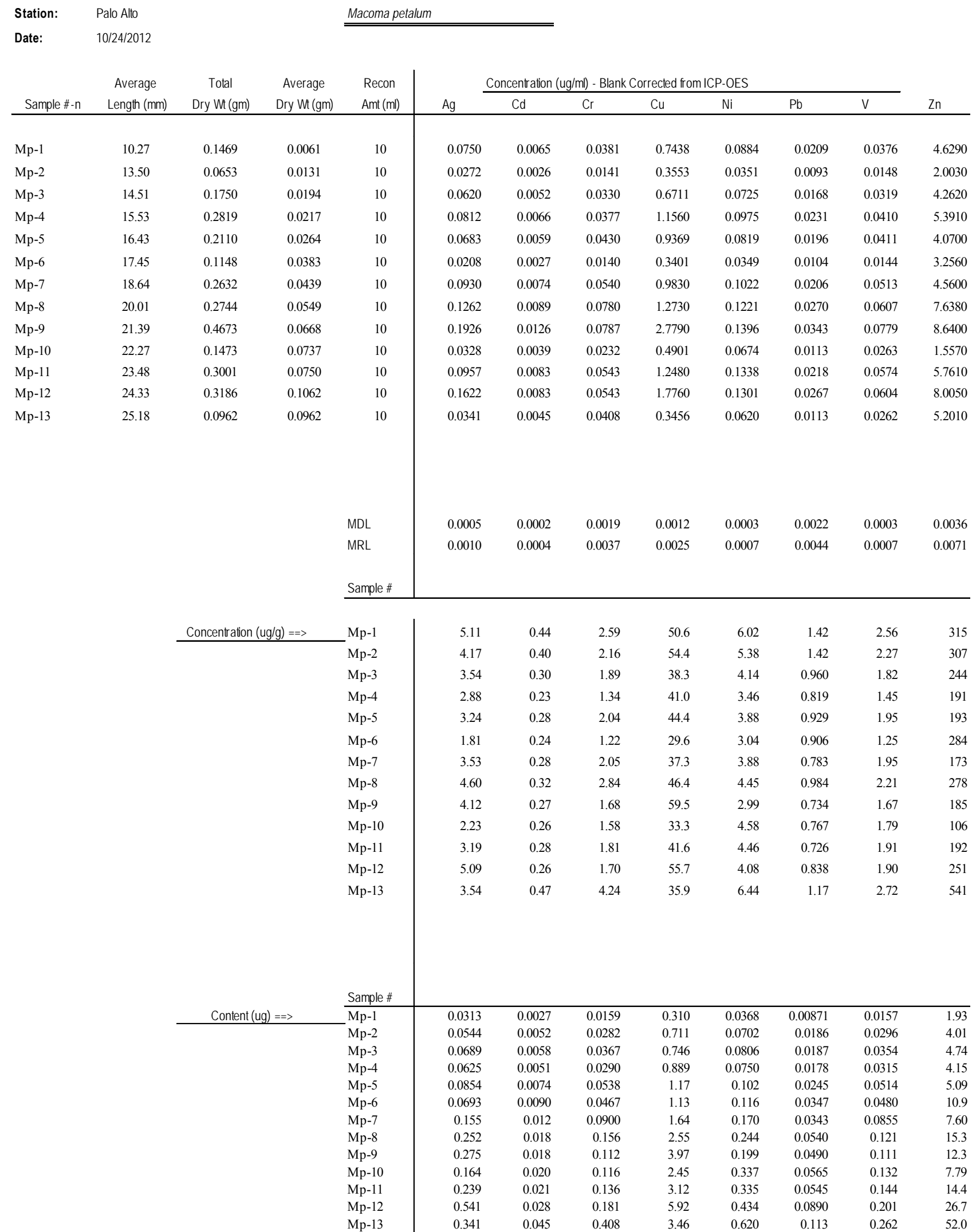




\begin{tabular}{|c|c|c|c|c|c|c|c|c|}
\hline \multirow{3}{*}{$\begin{array}{l}\text { Station: } \\
\text { Date: }\end{array}$} & \multirow{2}{*}{$\begin{array}{l}\text { Palo Alto } \\
\text { 12/7/2012 }\end{array}$} & \multicolumn{3}{|c|}{ Statistical Summary } & \multirow[b]{3}{*}{$\mathrm{Ni}$} & \multirow[b]{3}{*}{$\mathrm{Pb}$} & \multirow[b]{3}{*}{$\mathrm{V}$} & \multirow[b]{3}{*}{$\mathrm{Zn}$} \\
\hline & & & & & & & & \\
\hline & $\mathrm{Ag}$ & $\mathrm{Cd}$ & $\mathrm{Cr}$ & $\mathrm{Cu}$ & & & & \\
\hline Mean $(\mathrm{mg} / \mathrm{kg})$ & 3.88 & 0.26 & 1.50 & 38.9 & 3.58 & 0.757 & 1.63 & 231 \\
\hline STD & 1.08 & 0.08 & 0.57 & 8.4 & 0.85 & 0.264 & 0.55 & 42 \\
\hline SEM & 0.30 & 0.02 & 0.16 & 2.3 & 0.24 & 0.073 & 0.15 & 12 \\
\hline $\mathrm{CV} \%$ & 27.8 & 32 & 37.7 & 21.6 & 23.8 & 35.0 & 33.6 & 18.2 \\
\hline$n$ & 13 & 13 & 13 & 13 & 13 & 13 & 13 & 13 \\
\hline rwtx[] & 0.098 & 0.76 & 0.747 & 0.137 & 0.624 & 0.757 & 0.719 & 0.143 \\
\hline X 100mg & 3.73 & 0.17 & 0.93 & 37.3 & 2.86 & 0.484 & 1.10 & 223 \\
\hline$r \mid x[]$ & 0.256 & 0.86 & 0.839 & 0.275 & 0.710 & 0.835 & 0.825 & 0.232 \\
\hline X 20mm & 3.81 & 0.24 & 1.39 & 38.3 & 3.44 & 0.70 & 1.53 & 228 \\
\hline$X 25 \mathrm{~mm}$ & 3.52 & 0.16 & 0.89 & 35.9 & 2.80 & 0.470 & 1.05 & 218 \\
\hline
\end{tabular}

Estimated content (ug) for $15 \mathrm{~mm}$ and $20 \mathrm{~mm}$ clam

\begin{tabular}{rrrrrrrrr} 
& $\mathrm{Ag}$ & $\mathrm{Cd}$ & $\mathrm{Cr}$ & $\mathrm{Cu}$ & $\mathrm{Ni}$ & $\mathrm{Pb}$ & $\mathrm{V}$ & $\mathrm{Zn}$ \\
\cline { 2 - 8 } & & & & & & & & \\
$20 \mathrm{~mm}$ & 0.190 & 0.012 & 0.0660 & 1.94 & 0.172 & 0.0339 & 0.0738 & 11.6 \\
$25 \mathrm{~mm}$ & 0.368 & 0.019 & 0.106 & 3.80 & 0.310 & 0.0556 & 0.122 & 23.0
\end{tabular}

$\begin{array}{rr}0.020 \mathrm{gm} & 0.052 \mathrm{gm} \\ 20 \mathrm{mg} & 52 \mathrm{mg}\end{array}$

Estimated weight for $25 \mathrm{~mm}$ clam

$0.106 \mathrm{gm}$

$106 \mathrm{mg}$ 


\begin{tabular}{|c|c|c|c|c|c|c|c|c|c|c|c|c|}
\hline \multirow{2}{*}{$\begin{array}{l}\text { Station: } \\
\text { Date: }\end{array}$} & \multicolumn{3}{|l|}{$\begin{array}{l}\text { Palo Alto } \\
12 / 7 / 2012\end{array}$} & \multicolumn{3}{|c|}{ Macoma petalum } & & \multirow[b]{3}{*}{$\mathrm{Pb}$} & \multirow[b]{3}{*}{$\mathrm{V}$} & \multirow[b]{3}{*}{$\mathrm{Zn}$} \\
\hline & Average & Total & Average & \multirow{2}{*}{$\begin{array}{l}\text { Recon } \\
\text { Amt (ml) }\end{array}$} & \multirow[b]{2}{*}{$\mathrm{Ag}$} & Concentration (ug/ml) - Blank Corrected from ICP-OES & & & & & & \\
\hline Sample \#-n & Length (mm) & Dry Wt (gm) & Dry Wt (gm) & & & $\mathrm{Cd}$ & $\mathrm{Cr}$ & $\mathrm{Cu}$ & $\mathrm{Ni}$ & & & \\
\hline $\mathrm{Mp}-1$ & 10.18 & 0.1127 & 0.0059 & 10 & 0.0732 & 0.0050 & 0.0278 & 0.6876 & 0.0609 & 0.0151 & 0.0303 & 3.6830 \\
\hline $\mathrm{Mp}-2$ & 12.92 & 0.1252 & 0.0125 & 10 & 0.0546 & 0.0042 & 0.0295 & 0.4474 & 0.0511 & 0.0124 & 0.0297 & 2.5330 \\
\hline Mp-3 & 14.63 & 0.1791 & 0.0224 & 10 & 0.0515 & 0.0048 & 0.0293 & 0.4669 & 0.0564 & 0.0125 & 0.0305 & 3.9290 \\
\hline Mp-4 & 15.28 & 0.1011 & 0.0202 & 10 & 0.0377 & 0.0036 & 0.0238 & 0.4570 & 0.0521 & 0.0114 & 0.0249 & 2.0630 \\
\hline Mp-5 & 16.71 & 0.2384 & 0.0265 & 10 & 0.0661 & 0.0067 & 0.0392 & 0.9046 & 0.0915 & 0.0196 & 0.0412 & 5.4930 \\
\hline Mp-6 & 18.09 & 0.2815 & 0.0352 & 10 & 0.0830 & 0.0054 & 0.0282 & 0.9156 & 0.0789 & 0.0169 & 0.0317 & 4.8380 \\
\hline Mp-7 & 19.48 & 0.2222 & 0.0444 & 10 & 0.0715 & 0.0059 & 0.0297 & 0.7451 & 0.0805 & 0.0195 & 0.0333 & 4.8300 \\
\hline Mp-8 & 20.64 & 0.3027 & 0.0605 & 10 & 0.1276 & 0.0069 & 0.0428 & 1.1520 & 0.0950 & 0.0215 & 0.0465 & 8.2350 \\
\hline Mp-9 & 21.65 & 0.3482 & 0.0696 & 10 & 0.1045 & 0.0056 & 0.0300 & 1.2560 & 0.0909 & 0.0174 & 0.0359 & 8.8240 \\
\hline Mp-10 & 22.63 & 0.3806 & 0.0761 & 10 & 0.2006 & 0.0074 & 0.0434 & 1.4160 & 0.1256 & 0.0194 & 0.0480 & 8.5940 \\
\hline Mp-11 & 23.35 & 0.3377 & 0.0844 & 10 & 0.1201 & 0.0074 & 0.0426 & 1.3430 & 0.1057 & 0.0187 & 0.0465 & 9.3830 \\
\hline Mp-12 & 24.21 & 0.2897 & 0.0966 & 10 & 0.1269 & 0.0050 & 0.0237 & 1.3390 & 0.0973 & 0.0143 & 0.0296 & 5.9060 \\
\hline Mp-13 & 25.63 & 0.3559 & 0.1186 & 10 & 0.1267 & 0.0073 & 0.0443 & 1.2760 & 0.1069 & 0.0218 & 0.0515 & 6.8870 \\
\hline & & & & MDL & 0.0005 & 0.0002 & 0.0019 & 0.0012 & 0.0003 & 0.0022 & 0.0003 & 0.0036 \\
\hline & & & & MRL & 0.0010 & 0.0004 & 0.0037 & 0.0025 & 0.0007 & 0.0044 & 0.0007 & 0.0071 \\
\hline & & & & Sample \# & & & & & & & & \\
\hline & & Concentration & $/ g)==>$ & Mp-1 & 6.50 & 0.44 & 2.47 & 61.0 & 5.40 & 1.34 & 2.69 & 327 \\
\hline & & & & $\mathrm{Mp}-2$ & 4.36 & 0.34 & 2.36 & 35.7 & 4.08 & 0.990 & 2.37 & 202 \\
\hline & & & & Mp-3 & 2.88 & 0.27 & 1.64 & 26.1 & 3.15 & 0.698 & 1.70 & 219 \\
\hline & & & & Mp-4 & 3.73 & 0.36 & 2.35 & 45.2 & 5.15 & 1.13 & 2.46 & 204 \\
\hline & & & & Mp-5 & 2.77 & 0.28 & 1.64 & 37.9 & 3.84 & 0.822 & 1.73 & 230 \\
\hline & & & & Mp-6 & 2.95 & 0.19 & 1.00 & 32.5 & 2.80 & 0.600 & 1.13 & 172 \\
\hline & & & & $\mathrm{Mp}-7$ & 3.22 & 0.27 & 1.34 & 33.5 & 3.62 & 0.878 & 1.50 & 217 \\
\hline & & & & Mp-8 & 4.22 & 0.23 & 1.41 & 38.1 & 3.14 & 0.710 & 1.54 & 272 \\
\hline & & & & Mp-9 & 3.00 & 0.16 & 0.86 & 36.1 & 2.61 & 0.500 & 1.03 & 253 \\
\hline & & & & Mp-10 & 5.27 & 0.19 & 1.14 & 37.2 & 3.30 & 0.510 & 1.26 & 226 \\
\hline & & & & Mp-11 & 3.56 & 0.22 & 1.26 & 39.8 & 3.13 & 0.554 & 1.38 & 278 \\
\hline & & & & Mp-12 & 4.38 & 0.17 & 0.818 & 46.2 & 3.36 & 0.494 & 1.02 & 204 \\
\hline & & & & Mp-13 & 3.56 & 0.21 & 1.24 & 35.9 & 3.00 & 0.613 & 1.45 & 194 \\
\hline & & & & Sample \# & & & & & & & & \\
\hline & & Content ( & $=\Rightarrow$ & Mp-1 & 0.0385 & 0.0026 & 0.0146 & 0.362 & 0.0321 & 0.00795 & 0.0159 & 1.94 \\
\hline & & & & $\mathrm{Mp}-2$ & 0.0546 & 0.0042 & 0.0295 & 0.447 & 0.0511 & 0.0124 & 0.0297 & 2.53 \\
\hline & & & & Mp-3 & 0.0644 & 0.0060 & 0.0366 & 0.584 & 0.0705 & 0.0156 & 0.0381 & 4.91 \\
\hline & & & & Mp-4 & 0.0754 & 0.0072 & 0.0476 & 0.914 & 0.104 & 0.0228 & 0.0498 & 4.13 \\
\hline & & & & Mp-5 & 0.0734 & 0.0074 & 0.0436 & 1.01 & 0.102 & 0.0218 & 0.0458 & 6.10 \\
\hline & & & & Mp-6 & 0.104 & 0.0068 & 0.0353 & 1.14 & 0.0986 & 0.0211 & 0.0396 & 6.05 \\
\hline & & & & Mp-7 & 0.143 & 0.012 & 0.0594 & 1.49 & 0.161 & 0.0390 & 0.0666 & 9.66 \\
\hline & & & & Mp-8 & 0.255 & 0.014 & 0.0856 & 2.30 & 0.190 & 0.0430 & 0.0930 & 16.5 \\
\hline & & & & Mp-9 & 0.209 & 0.011 & 0.0600 & 2.51 & 0.182 & 0.0348 & 0.0718 & 17.6 \\
\hline & & & & $\mathrm{Mp}-10$ & 0.401 & 0.015 & 0.0868 & 2.83 & 0.251 & 0.0388 & 0.0960 & 17.2 \\
\hline & & & & Mp-11 & 0.300 & 0.019 & 0.107 & 3.36 & 0.264 & 0.0468 & 0.116 & 23.5 \\
\hline & & & & $\mathrm{Mp}-12$ & 0.423 & 0.017 & 0.0790 & 4.46 & 0.324 & 0.0477 & 0.0987 & 19.7 \\
\hline & & & & Mp-13 & 0.422 & 0.024 & 0.148 & 4.25 & 0.356 & 0.0727 & 0.172 & 23.0 \\
\hline
\end{tabular}


Appendix 4. Mercury and selenium concentrations ( $\mathrm{mg} / \mathrm{kg}$ dry weight) determined in sample splits of surface sediments and Macoma petalum collected at Palo Alto, Calif., 2012.

[Two sediment samples and three clam tissue samples were split and analyzed for Se and $\mathrm{Hg}$. The split results are shown here.]

\begin{tabular}{lcccc}
\hline Date & \multicolumn{2}{c}{ Sediment } & \multicolumn{2}{c}{ M. petalum } \\
\hline & mercury & selenium & mercury & selenium \\
\cline { 2 - 5 } $2 / 14 / 2012$ & -- & -- & -- & $4.25 \backslash 4.17$ \\
$4 / 25 / 2012$ & $0.27 \backslash 0.23$ & $0.31 \backslash 0.30$ & $0.20 \backslash 0.20$ & -- \\
$6 / 5 / 2012$ & -- & $0.30 \backslash 0.30$ & -- & -- \\
$12 / 7 / 2012$ & -- & -- & $0.27 \backslash 0.30$ & -- \\
\hline
\end{tabular}


Appendix 5. Results of the analyses of National Institute of Science and Technology (NIST) standard reference material 2709a (San Joaquin Soil) for elements, excluding selenium and mercury.

[Recoveries are reported as the observed concentrations (milligram per kilogram, dry weight (mg/kg)) and the percent recoveries relative to the certified values for the standard.]

\begin{tabular}{|c|c|c|c|c|c|c|c|c|c|c|c|c|}
\hline Month & Rep & Al & As & Cd & $\mathrm{Cr}$ & $\mathrm{Cu}$ & $\mathrm{Fe}$ & $\mathrm{Mn}$ & $\mathrm{Ni}$ & $\mathrm{Pb}$ & V & $\mathrm{Zn}$ \\
\hline & & \multicolumn{11}{|c|}{ Observed concentration } \\
\hline \multirow[t]{2}{*}{$1 / 17 / 2012$} & 1 & 56,761 & 6 & 0.29 & 105 & 27 & 25,716 & 477 & 77 & 12 & 86 & 112 \\
\hline & 2 & 57,997 & 6 & 0.31 & 105 & 28 & 25,772 & 479 & 77 & 12 & 87 & 113 \\
\hline \multirow[t]{2}{*}{$2 / 14 / 2012$} & 1 & 57,576 & 6 & 0.30 & 104 & 28 & 25,594 & 472 & 76 & 12 & 86 & 110 \\
\hline & 2 & 57,938 & 6 & 0.30 & 105 & 28 & 25,883 & 484 & 78 & 12 & 87 & 113 \\
\hline \multirow[t]{2}{*}{$3 / 26 / 2012$} & 1 & 54,570 & 6 & 0.28 & 99 & 26 & 24,251 & 452 & 72 & 11 & 81 & 105 \\
\hline & 2 & 57,118 & 6 & 0.27 & 101 & 27 & 24,643 & 454 & 73 & 12 & 85 & 106 \\
\hline \multirow[t]{2}{*}{$4 / 25 / 2012$} & 1 & 37,820 & 6 & 0.29 & 98 & 27 & 28,820 & 446 & 71 & 11 & 81 & 100 \\
\hline & 2 & 38,731 & 6 & 0.29 & 101 & 27 & 29,522 & 456 & 72 & 11 & 83 & 102 \\
\hline \multirow[t]{2}{*}{$5 / 14 / 2012$} & 1 & 38,548 & 6 & 0.29 & 101 & 28 & 29,050 & 449 & 71 & 11 & 83 & 101 \\
\hline & 2 & 37,989 & 6 & 0.30 & 99 & 27 & 28,994 & 451 & 71 & 11 & 82 & 101 \\
\hline \multirow[t]{2}{*}{$6 / 5 / 2012$} & 1 & 39,989 & 6 & 0.28 & 102 & 29 & 29,722 & 461 & 73 & 11 & 82 & 104 \\
\hline & 2 & 38,200 & 6 & 0.26 & 99 & 27 & 29,388 & 457 & 72 & 11 & 82 & 102 \\
\hline \multirow[t]{2}{*}{ 9/17/2012 } & 1 & 39,327 & 6 & 0.29 & 101 & 29 & 29,250 & 454 & 71 & 11 & 84 & 104 \\
\hline & 2 & 37,961 & 6 & 0.25 & 98 & 29 & 28,612 & 447 & 69 & 10 & 80 & 100 \\
\hline \multirow[t]{2}{*}{$10 / 24 / 2012$} & 1 & 37,066 & 6 & 0.25 & 97 & 27 & 28,648 & 442 & 69 & 11 & 79 & 98 \\
\hline & 2 & 37,273 & 6 & 0.27 & 97 & 28 & 28,735 & 448 & 70 & 11 & 79 & 99 \\
\hline \multirow[t]{5}{*}{$12 / 7 / 2012$} & 1 & 38,622 & 6 & 0.28 & 100 & 29 & 29,076 & 452 & 71 & 10 & 83 & 101 \\
\hline & 2 & 38,061 & 6 & 0.28 & 98 & 29 & 28,385 & 447 & 69 & 10 & 81 & 99 \\
\hline & \multicolumn{12}{|c|}{ Certified concentration } \\
\hline & Mean & 73,700 & 11 & 0.371 & 130 & 34 & 33,600 & 529 & 85 & 17 & 110 & 103 \\
\hline & St. dev. & 1,600 & 0.3 & 0.002 & 9 & 1 & 700 & 18 & 2 & 0.1 & 11 & 4 \\
\hline \multirow[t]{2}{*}{ Month } & Rep & Al & As & $\mathrm{Cd}$ & $\mathrm{Cr}$ & $\mathrm{Cu}$ & $\mathrm{Fe}$ & $\mathrm{Mn}$ & $\mathrm{Ni}$ & $\mathrm{Pb}$ & V & $\mathrm{Zn}$ \\
\hline & \multicolumn{12}{|c|}{ Percent recovery } \\
\hline \multirow[t]{2}{*}{$1 / 17 / 2012$} & 1 & 77 & 61 & 78 & 81 & 79 & 77 & 90 & 91 & 68 & 79 & 109 \\
\hline & 2 & 79 & 62 & 85 & 81 & 84 & 77 & 91 & 91 & 70 & 79 & 109 \\
\hline \multirow[t]{2}{*}{$2 / 14 / 2012$} & 1 & 78 & 58 & 81 & 80 & 84 & 76 & 89 & 90 & 67 & 78 & 107 \\
\hline & 2 & 79 & 60 & 82 & 81 & 83 & 77 & 92 & 91 & 68 & 79 & 109 \\
\hline \multirow[t]{2}{*}{$3 / 26 / 2012$} & 1 & 74 & 53 & 77 & 76 & 78 & 72 & 85 & 85 & 63 & 74 & 102 \\
\hline & 2 & 78 & 60 & 72 & 77 & 81 & 73 & 86 & 86 & 67 & 77 & 103 \\
\hline \multirow[t]{2}{*}{$4 / 25 / 2012$} & 1 & 51 & 58 & 79 & 75 & 79 & 86 & 84 & 83 & 62 & 74 & 97 \\
\hline & 2 & 53 & 58 & 78 & 77 & 81 & 88 & 86 & 84 & 63 & 76 & 99 \\
\hline \multirow[t]{2}{*}{$5 / 14 / 2012$} & 1 & 52 & 59 & 77 & 77 & 81 & 86 & 85 & 84 & 62 & 75 & 98 \\
\hline & 2 & 52 & 59 & 80 & 76 & 80 & 86 & 85 & 84 & 61 & 74 & 98 \\
\hline \multirow[t]{2}{*}{$6 / 5 / 2012$} & 1 & 54 & 57 & 76 & 78 & 86 & 88 & 87 & 86 & 64 & 74 & 101 \\
\hline & 2 & 52 & 57 & 70 & 76 & 80 & 87 & 86 & 85 & 61 & 74 & 99 \\
\hline \multirow[t]{2}{*}{$9 / 17 / 2012$} & 1 & 53 & 60 & 78 & 78 & 85 & 87 & 86 & 84 & 64 & 76 & 101 \\
\hline & 2 & 52 & 58 & 67 & 75 & 86 & 85 & 85 & 81 & 59 & 73 & 97 \\
\hline $10 / 24 / 2012$ & 1 & 50 & 58 & 67 & 75 & 78 & 85 & 84 & 82 & 62 & 72 & 95 \\
\hline & 2 & 51 & 57 & 73 & 74 & 83 & 86 & 85 & 83 & 61 & 72 & 97 \\
\hline $12 / 7 / 2012$ & 1 & 52 & 61 & 77 & 77 & 84 & 87 & 85 & 84 & 61 & 75 & 98 \\
\hline & 2 & 52 & 59 & 75 & 75 & 87 & 84 & 84 & 81 & 60 & 74 & 96 \\
\hline & Mean & 61 & 58 & 76 & 77 & 82 & 83 & 87 & 85 & 64 & 75 & 101 \\
\hline & St. dev. & 13 & 2 & 5 & 2 & 3 & 6 & 2 & 3 & 3 & 2 & 5 \\
\hline
\end{tabular}


Appendix 6. Observed and certified values for inorganic elements in NIST Standard Reference Material 2976 (mussel tissue) prepared in 2012.

[Observed Concentrations in NIST SRM 2976 in 2012. Concentration unit is mg/kg (dry weight). Observed concentrations for different dates are the mean and 1 standard deviation. Certified concentrations are the mean and 95\% confidence interval. MRL means Method Reporting Level.] 


\begin{tabular}{|c|c|c|c|c|c|c|c|c|c|}
\hline Month & Rep & $\mathrm{Ag}$ & $\mathrm{Cd}$ & $\mathrm{Cr}$ & $\mathrm{Cu}$ & $\mathrm{Ni}$ & $\mathrm{Pb}$ & V & $\mathrm{Zn}$ \\
\hline & & \multicolumn{8}{|c|}{ Observed concentration } \\
\hline \multirow[t]{3}{*}{$1 / 17 / 2012$} & 1 & $<\mathrm{MRL}$ & 0.58 & 0.6 & 3.81 & 0.55 & 0.70 & 0.596 & 134 \\
\hline & 2 & 0.010 & 0.58 & 0.6 & 3.83 & 0.54 & 0.72 & 0.607 & 136 \\
\hline & 3 & $<\mathrm{MRL}$ & 0.57 & 0.7 & 3.83 & 0.56 & 0.76 & 0.589 & 134 \\
\hline \multirow[t]{3}{*}{ 2/14/2012 } & 1 & $<\mathrm{MRL}$ & 0.63 & 0.7 & 3.94 & 0.59 & 0.88 & 0.631 & 145 \\
\hline & 2 & $<\mathrm{MRL}$ & 0.62 & 0.6 & 3.88 & 0.57 & 0.85 & 0.632 & 142 \\
\hline & 3 & $<\mathrm{MRL}$ & 0.63 & 0.7 & 3.88 & 0.56 & 0.88 & 0.636 & 142 \\
\hline \multirow[t]{3}{*}{$3 / 26 / 2012$} & 1 & $<\mathrm{MRL}$ & 0.60 & 0.6 & 4.05 & 0.56 & 0.81 & 0.631 & 139 \\
\hline & 2 & 0.003 & 0.62 & 0.7 & 3.90 & 0.57 & 0.85 & 0.620 & 140 \\
\hline & 3 & 0.014 & 0.61 & 0.6 & 3.78 & 0.56 & 0.81 & 0.628 & 138 \\
\hline \multirow[t]{3}{*}{$4 / 25 / 2012$} & 1 & 0.010 & 0.58 & 0.7 & 3.72 & 0.56 & 0.80 & 0.640 & 131 \\
\hline & 2 & 0.010 & 0.60 & 0.6 & 3.67 & 0.55 & 0.80 & 0.608 & 134 \\
\hline & 3 & $<\mathrm{MRL}$ & 0.60 & 0.6 & 3.75 & 0.54 & 0.79 & 0.620 & 135 \\
\hline \multirow[t]{3}{*}{$5 / 14 / 2012$} & 1 & $<\mathrm{MRL}$ & 0.57 & 0.6 & 3.60 & 0.54 & 0.73 & 0.586 & 127 \\
\hline & 2 & $<\mathrm{MRL}$ & 0.55 & 0.5 & 3.55 & 0.51 & 0.71 & 0.564 & 126 \\
\hline & 3 & $<\mathrm{MRL}$ & 0.54 & 0.5 & 3.43 & 0.51 & 0.69 & 0.548 & 123 \\
\hline \multirow[t]{3}{*}{$6 / 5 / 2012$} & 1 & $<\mathrm{MRL}$ & 0.60 & 0.6 & 3.68 & 0.54 & 0.79 & 0.595 & 134 \\
\hline & 2 & $<\mathrm{MRL}$ & 0.60 & 0.6 & 3.71 & 0.54 & 0.80 & 0.608 & 135 \\
\hline & 3 & $<\mathrm{MRL}$ & 0.60 & 0.6 & 3.72 & 0.55 & 0.81 & 0.612 & 138 \\
\hline \multirow[t]{3}{*}{$9 / 17 / 2012$} & 1 & $<\mathrm{MRL}$ & 0.60 & 0.4 & 3.64 & 0.55 & 0.79 & 0.599 & 134 \\
\hline & 2 & $<\mathrm{MRL}$ & 0.58 & 0.4 & 3.59 & 0.53 & 0.78 & 0.597 & 131 \\
\hline & 3 & $<\mathrm{MRL}$ & 0.58 & 0.7 & 3.60 & 0.52 & 0.83 & 0.588 & 134 \\
\hline \multirow[t]{3}{*}{$10 / 24 / 2012$} & 1 & $<\mathrm{MRL}$ & 0.57 & 0.4 & 3.43 & 0.50 & 0.77 & 0.554 & 128 \\
\hline & 2 & 0.003 & 0.58 & 0.4 & 3.45 & 0.50 & 0.74 & 0.559 & 131 \\
\hline & 3 & 0.007 & 0.58 & 0.4 & 3.46 & 0.52 & 0.73 & 0.559 & 129 \\
\hline \multirow{6}{*}{$12 / 7 / 2012$} & 1 & $<\mathrm{MRL}$ & 0.57 & 0.6 & 3.43 & 0.56 & 0.74 & 0.557 & 127 \\
\hline & 2 & 0.011 & 0.59 & 0.4 & 3.36 & 0.54 & 0.76 & 0.578 & 132 \\
\hline & 3 & 0.003 & 0.58 & 0.4 & 3.42 & 0.52 & 0.77 & 0.569 & 131 \\
\hline & & \multicolumn{8}{|c|}{ Certified concentration } \\
\hline & Mean & 0.011 & 0.82 & 0.5 & 4.02 & 0.93 & 1.19 & unknown & 137 \\
\hline & $95 \% \mathrm{CI}$ & 0.005 & 0.16 & 0.2 & 0.33 & 0.12 & 0.18 & unknown & 13 \\
\hline \multirow[t]{2}{*}{ Month } & Rep & As & $\mathrm{Cd}$ & $\mathrm{Cr}$ & $\mathrm{Cu}$ & $\mathrm{Ni}$ & $\mathrm{Pb}$ & V & $\mathrm{Zn}$ \\
\hline & & \multicolumn{8}{|c|}{ Percent recovery } \\
\hline $1 / 17 / 2012$ & 1 & & 71 & 125 & 95 & 59 & 59 & - & 98 \\
\hline & 2 & 90 & 71 & 122 & 95 & 58 & 61 & - & 99 \\
\hline & 3 & & 70 & 131 & 95 & 60 & 64 & - & 98 \\
\hline $2 / 14 / 2012$ & 1 & & 77 & 133 & 98 & 64 & 74 & - & 106 \\
\hline & 2 & & 75 & 123 & 97 & 62 & 72 & - & 103 \\
\hline & 3 & & 76 & 132 & 96 & 60 & 74 & - & 103 \\
\hline $3 / 26 / 2012$ & 1 & & 73 & 126 & 101 & 60 & 68 & - & 102 \\
\hline & 2 & 31 & 75 & 132 & 97 & 62 & 72 & - & 102 \\
\hline & 3 & 125 & 74 & 121 & 94 & 60 & 68 & - & 101 \\
\hline $4 / 25 / 2012$ & 1 & 93 & 70 & 130 & 93 & 60 & 67 & - & 95 \\
\hline & 2 & 92 & 73 & 114 & 91 & 59 & 67 & - & 97 \\
\hline & 3 & & 73 & 114 & 93 & 59 & 67 & - & 99 \\
\hline $5 / 14 / 2012$ & 1 & & 69 & 120 & 90 & 58 & 62 & - & 93 \\
\hline & 2 & & 67 & 105 & 88 & 55 & 59 & - & 92 \\
\hline & 3 & & 66 & 99 & 85 & 54 & 58 & - & 90 \\
\hline $6 / 5 / 2012$ & 1 & & 73 & 116 & 92 & 58 & 67 & - & 98 \\
\hline & 2 & & 73 & 119 & 92 & 59 & 67 & - & 98 \\
\hline & 3 & & 73 & 113 & 92 & 59 & 68 & - & 101 \\
\hline $9 / 17 / 2012$ & 1 & & 73 & 89 & 91 & 59 & 66 & - & 97 \\
\hline & 2 & & 71 & 87 & 89 & 57 & 65 & - & 96 \\
\hline & 3 & & 71 & 143 & 90 & 56 & 70 & - & 98 \\
\hline $10 / 24 / 2012$ & 1 & & 69 & 81 & 85 & 53 & 65 & - & 94 \\
\hline & 2 & 29 & 71 & 77 & 86 & 54 & 63 & - & 96 \\
\hline & 3 & 60 & 70 & 77 & 86 & 56 & 61 & - & 94 \\
\hline $12 / 7 / 2012$ & 1 & & 70 & 111 & 85 & 61 & 63 & - & 93 \\
\hline & 2 & 95 & 72 & 85 & 84 & 58 & 64 & - & 96 \\
\hline & 3 & 30 & 71 & 86 & 85 & 56 & 64 & - & 96 \\
\hline & Mean & 72 & 72 & 112 & 91 & 58 & 66 & unknown & 98 \\
\hline & St. dev. & 35 & 3 & 19 & 5 & 3 & 4 & unknown & 4 \\
\hline
\end{tabular}


Appendix 7. Method detection limits (MDL) and reporting levels (MRL) for ICP-OES methods.

[Concentration is reported as microgram per milliliter $(\mu \mathrm{g} / \mathrm{mL})$.]

\begin{tabular}{|c|c|c|c|c|c|c|c|c|c|c|c|c|}
\hline Method & Marker & $\mathrm{Ag}$ & Al & $\mathrm{Cd}$ & $\mathrm{Cr}$ & $\mathrm{Cu}$ & $\mathrm{Fe}$ & $M n$ & $\mathrm{Ni}$ & $\mathrm{Pb}$ & V & $\mathrm{Zn}$ \\
\hline \multirow[t]{2}{*}{ Sediment } & MDL & 0.0004 & 0.0074 & 0.0001 & 0.0016 & 0.0014 & 0.0114 & 0.0012 & 0.0007 & 0.0024 & 0.0045 & 0.0050 \\
\hline & MRL & 0.0008 & 0.0148 & 0.0003 & 0.0032 & 0.0029 & 0.0228 & 0.0025 & 0.0013 & 0.0047 & 0.0089 & 0.0100 \\
\hline \multirow[t]{2}{*}{ Tissue } & MDL & 0.0005 & ND & 0.0002 & 0.0019 & 0.0012 & 0.0050 & 0.0003 & 0.0003 & 0.0022 & 0.0003 & 0.0036 \\
\hline & MRL & 0.0010 & ND & 0.0004 & 0.0037 & 0.0025 & 0.0100 & 0.0006 & 0.0007 & 0.0044 & 0.0007 & 0.0071 \\
\hline
\end{tabular}


Appendix 8. Observed and certified concentrations of mercury and selenium in standard reference materials (SRM) analyzed in 2012.

[Concentration is reported as $\mathrm{mg} / \mathrm{kg}$.]

\begin{tabular}{|c|c|c|c|c|c|c|}
\hline & & Mercury & & & Selenium & \\
\hline SRM & Observed & Certified & $\begin{array}{l}\text { Percent } \\
\text { Recovery }\end{array}$ & Observed & Certified & $\begin{array}{l}\text { Percent } \\
\text { Recovery }\end{array}$ \\
\hline NIST 2976 & 0.064 & $0.06 \pm 0.01$ & 105 & $\begin{array}{l}1.63 \pm 0.05 \\
1.76 \pm 0.01\end{array}$ & $1.8 \pm 0.2$ & $\begin{array}{l}91 \\
98\end{array}$ \\
\hline PACS-2 & 2.76 & $3.04 \pm 0.2$ & 91 & $\begin{array}{l}0.92 \pm 0.03 \\
0.96 \pm 0.00\end{array}$ & $0.92 \pm 0.22$ & $\begin{array}{l}100 \\
104\end{array}$ \\
\hline
\end{tabular}


Appendix 9. Annual mean silver and annual mean copper in sediments and the clam Macoma petalum, Palo Alto, Calif., 1977-2012.

[Mean, Median, Minimum, and Maximum are calculated from all data between 1977-2012. The 2012 column presents the current 2012 data. Values for the 2012 column are annual (grand) means for 9 to 13 separate samples and standard errors of those means, the rest of the columns are statistics from the grand means of 1977-2012. Samples were collected between January and December of each year. Units are milligrams per kilogram dry weight of soft tissue for the clam (Macoma petalum) and milligram per kilogram dry weight for sediment. $\mathrm{HCl}$ refers to hydrochloric acid extractable copper and silver.]

\begin{tabular}{cccccc}
\hline Type of Analysis & 2012 & Mean & Median & Minimum & Maximum \\
\hline Copper & & & & & \\
\hline Sediment $-\mathrm{HCl}$ & $14 \pm 1$ & 23 & 20 & 13 & 55 \\
Sediment - Total & $39 \pm 2$ & 45 & 44 & 30 & 86 \\
Clams & $33 \pm 4$ & 80 & 44 & 24 & 287 \\
\hline Silver & & & & & \\
\hline Sediment - HCl & $0.30 \pm 0.02$ & 0.52 & 0.36 & 0.20 & 1.6 \\
Clams & $2.6 \pm 0.5$ & 25 & 5.5 & 1.8 & 106 \\
\hline
\end{tabular}


Appendix 10. Complete list of benthic species found at Palo Alto in the year 2012.

[Three samples are taken at each sampling event. The mean and standard deviation of the three samples are shown.] 
TAXON

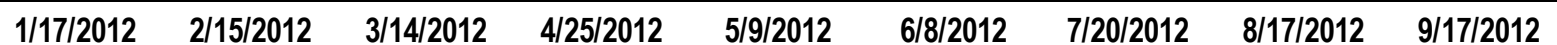

Mean std dev Mean std dev Mean std dev Mean std dev Mean std dev Mean std dev Mean std dev Mean std dev Mean std dev

\section{PHYLUM ANNELIDA}

\section{Class Oligochaeta}

\begin{tabular}{|c|c|c|c|c|c|c|c|c|c|c|c|c|c|c|c|c|c|c|}
\hline Naididae unid. spp. & 0.0 & 0.0 & 0.0 & 0.0 & 0.0 & 0.0 & 0.0 & 0.0 & 0.0 & 0.0 & 0.0 & 0.0 & 0.0 & 0.0 & 0.0 & 0.0 & 0.0 & 0.0 \\
\hline Oligochaeta unid. spp. & 0.0 & 0.0 & 0.0 & 0.0 & 0.0 & 0.0 & 0.0 & 0.0 & 0.0 & 0.0 & 0.0 & 0.0 & 0.0 & 0.0 & 0.0 & 0.0 & 1.0 & 1.7 \\
\hline Tubificidae unid. spp. & 24.0 & 22.9 & 3.0 & 5.2 & 12.7 & 11.0 & 8.0 & 5.6 & 3.3 & 3.2 & 4.0 & 2.6 & 12.3 & 10.6 & 5.7 & 4.6 & 4.3 & 1.5 \\
\hline \multicolumn{19}{|l|}{ Class Polychaeta } \\
\hline Capitella capitata complex & 0.0 & 0.0 & 0.0 & 0.0 & 0.3 & 0.6 & 0.0 & 0.0 & 0.0 & 0.0 & 0.0 & 0.0 & 0.0 & 0.0 & 0.0 & 0.0 & 0.0 & 0.0 \\
\hline Cirratulidae unid. spp. & 0.0 & 0.0 & 0.0 & 0.0 & 0.0 & 0.0 & 0.0 & 0.0 & 0.0 & 0.0 & 0.0 & 0.0 & 0.0 & 0.0 & 0.0 & 0.0 & 0.3 & 0.6 \\
\hline Eteone lighti & 4.3 & 2.5 & 2.0 & 2.6 & 4.0 & 2.0 & 3.3 & 1.5 & 10.7 & 2.1 & 6.3 & 4.9 & 5.7 & 2.9 & 6.0 & 3.6 & 6.7 & 5.9 \\
\hline Eteone unid. spp. & 0.0 & 0.0 & 0.0 & 0.0 & 0.0 & 0.0 & 0.0 & 0.0 & 0.0 & 0.0 & 0.0 & 0.0 & 0.0 & 0.0 & 0.0 & 0.0 & 0.0 & 0.0 \\
\hline Euchone limnicola & 0.0 & 0.0 & 0.0 & 0.0 & 0.0 & 0.0 & 0.0 & 0.0 & 0.0 & 0.0 & 0.0 & 0.0 & 0.0 & 0.0 & 0.0 & 0.0 & 0.0 & 0.0 \\
\hline Euchone unid. spp. & 0.0 & 0.0 & 0.0 & 0.0 & 0.0 & 0.0 & 0.0 & 0.0 & 0.0 & 0.0 & 0.0 & 0.0 & 0.0 & 0.0 & 0.0 & 0.0 & 0.0 & 0.0 \\
\hline Glycera unid. spp. & 0.0 & 0.0 & 0.0 & 0.0 & 0.0 & 0.0 & 3.3 & 2.9 & 3.7 & 3.5 & 0.0 & 0.0 & 0.0 & 0.0 & 0.0 & 0.0 & 0.0 & 0.0 \\
\hline Glycinde armigera & 0.0 & 0.0 & 0.0 & 0.0 & 0.0 & 0.0 & 0.0 & 0.0 & 0.0 & 0.0 & 0.0 & 0.0 & 0.0 & 0.0 & 0.0 & 0.0 & 0.0 & 0.0 \\
\hline Glycinde picta & 0.0 & 0.0 & 0.0 & 0.0 & 0.0 & 0.0 & 0.0 & 0.0 & 0.0 & 0.0 & 0.0 & 0.0 & 0.0 & 0.0 & 0.0 & 0.0 & 0.0 & 0.0 \\
\hline Glycinde unid. sp. SF1 & 0.0 & 0.0 & 0.0 & 0.0 & 0.0 & 0.0 & 0.0 & 0.0 & 0.0 & 0.0 & 0.3 & 0.6 & 0.0 & 0.0 & 0.0 & 0.0 & 0.0 & 0.0 \\
\hline Glycinde unid. spp. & 0.0 & 0.0 & 0.0 & 0.0 & 0.0 & 0.0 & 0.7 & 1.2 & 0.7 & 1.2 & 0.0 & 0.0 & 0.0 & 0.0 & 0.0 & 0.0 & 0.0 & 0.0 \\
\hline Harmothoe imbricata & 0.0 & 0.0 & 0.0 & 0.0 & 0.0 & 0.0 & 0.0 & 0.0 & 0.0 & 0.0 & 0.0 & 0.0 & 0.0 & 0.0 & 0.0 & 0.0 & 0.0 & 0.0 \\
\hline Heteromastus filiformis & 2.7 & 0.6 & 2.7 & 3.8 & 2.0 & 1.0 & 3.0 & 1.0 & 1.0 & 0.0 & 1.3 & 1.2 & 2.3 & 1.2 & 3.0 & 2.6 & 2.3 & 1.5 \\
\hline Maldanidae unid. spp. & 0.0 & 0.0 & 0.0 & 0.0 & 0.0 & 0.0 & 0.0 & 0.0 & 0.0 & 0.0 & 0.0 & 0.0 & 0.0 & 0.0 & 0.0 & 0.0 & 0.0 & 0.0 \\
\hline Marphysa sanguinea & 0.0 & 0.0 & 0.0 & 0.0 & 0.0 & 0.0 & 0.0 & 0.0 & 0.0 & 0.0 & 0.0 & 0.0 & 0.0 & 0.0 & 0.0 & 0.0 & 0.0 & 0.0 \\
\hline Neanthes succinea & 0.3 & 0.6 & 0.7 & 1.2 & 1.7 & 1.5 & 2.3 & 2.5 & 0.7 & 0.6 & 0.3 & 0.6 & 2.0 & 1.0 & 1.7 & 0.6 & 0.0 & 0.0 \\
\hline Polychaeta unid. spp. & 0.0 & 0.0 & 0.0 & 0.0 & 0.0 & 0.0 & 0.0 & 0.0 & 0.0 & 0.0 & 0.0 & 0.0 & 0.0 & 0.0 & 0.0 & 0.0 & 0.0 & 0.0 \\
\hline Polydora cornuta & 0.0 & 0.0 & 0.0 & 0.0 & 0.0 & 0.0 & 0.0 & 0.0 & 0.0 & 0.0 & 0.0 & 0.0 & 0.0 & 0.0 & 0.0 & 0.0 & 0.0 & 0.0 \\
\hline Polydora unid. spp. & 0.0 & 0.0 & 0.0 & 0.0 & 0.0 & 0.0 & 0.0 & 0.0 & 0.0 & 0.0 & 0.0 & 0.0 & 0.0 & 0.0 & 0.0 & 0.0 & 0.0 & 0.0 \\
\hline Pseudopolydora kempi & 0.0 & 0.0 & 0.0 & 0.0 & 0.0 & 0.0 & 0.0 & 0.0 & 0.0 & 0.0 & 0.0 & 0.0 & 0.0 & 0.0 & 0.0 & 0.0 & 0.0 & 0.0 \\
\hline
\end{tabular}




\begin{tabular}{|c|c|c|c|c|c|c|c|c|c|c|c|c|c|c|c|c|c|c|}
\hline \multirow{2}{*}{ TAXON } & \multicolumn{2}{|c|}{$1 / 17 / 2012$} & \multicolumn{2}{|c|}{ 2/15/2012 } & \multicolumn{2}{|c|}{$3 / 14 / 2012$} & \multicolumn{2}{|c|}{$4 / 25 / 2012$} & \multicolumn{2}{|c|}{$5 / 9 / 2012$} & \multicolumn{2}{|c|}{$6 / 8 / 2012$} & \multicolumn{2}{|c|}{$7 / 20 / 2012$} & \multicolumn{2}{|c|}{$8 / 17 / 2012$} & \multicolumn{2}{|c|}{ 9/17/2012 } \\
\hline & Mean & std dev & Mean & std dev & Mean & std dev & Mean & std dev & Mean & std dev & Mean & std dev & Mean & std dev & Mean & std dev & Mean & std dev \\
\hline Sabaco elongatus & 0.0 & 0.0 & 0.0 & 0.0 & 0.0 & 0.0 & 0.0 & 0.0 & 0.0 & 0.0 & 0.0 & 0.0 & 0.0 & 0.0 & 0.0 & 0.0 & 0.0 & 0.0 \\
\hline Sphaerosyllis californiensis & 0.0 & 0.0 & 0.0 & 0.0 & 0.0 & 0.0 & 0.0 & 0.0 & 0.0 & 0.0 & 0.0 & 0.0 & 0.0 & 0.0 & 0.0 & 0.0 & 0.0 & 0.0 \\
\hline Sphaerosyllis erinaceus & 0.0 & 0.0 & 0.0 & 0.0 & 0.0 & 0.0 & 0.0 & 0.0 & 0.0 & 0.0 & 0.0 & 0.0 & 0.0 & 0.0 & 0.0 & 0.0 & 0.0 & 0.0 \\
\hline Sphaerosyllis unid. sp. A & 0.0 & 0.0 & 0.0 & 0.0 & 0.0 & 0.0 & 0.0 & 0.0 & 0.0 & 0.0 & 0.0 & 0.0 & 0.0 & 0.0 & 0.0 & 0.0 & 0.0 & 0.0 \\
\hline Streblospio benedicti & 20.3 & 15.5 & 6.7 & 9.9 & 17.0 & 6.9 & 8.7 & 2.5 & 3.7 & 2.5 & 15.3 & 8.7 & 3.0 & 2.6 & 11.3 & 9.0 & 0.7 & 1.2 \\
\hline Spionidae unid. spp. & 0.0 & 0.0 & 0.0 & 0.0 & 0.0 & 0.0 & 0.0 & 0.0 & 0.0 & 0.0 & 0.0 & 0.0 & 0.0 & 0.0 & 0.0 & 0.0 & 0.0 & 0.0 \\
\hline
\end{tabular}

PHYLUM ARTHROPODA

\section{Class Arachnida}

Acari

$\begin{array}{llllllllllllllllll}0.0 & 0.0 & 0.0 & 0.0 & 0.0 & 0.0 & 0.0 & 0.0 & 0.0 & 0.0 & 0.0 & 0.0 & 0.0 & 0.0 & 0.0 & 0.0 & 0.0 & 0.0\end{array}$

Class Copepoda

Calanoida unid. spp.

$\begin{array}{llllllllllllllllll}0.0 & 0.0 & 0.0 & 0.0 & 0.0 & 0.0 & 0.0 & 0.0 & 0.0 & 0.0 & 0.0 & 0.0 & 0.0 & 0.0 & 0.0 & 0.0 & 0.0 & 0.0\end{array}$

Harpacticoida unid. spp.

$\begin{array}{llllllllllllllllll}0.0 & 0.0 & 0.0 & 0.0 & 0.3 & 0.6 & 0.0 & 0.0 & 3.7 & 3.1 & 0.0 & 0.0 & 0.0 & 0.0 & 0.7 & 0.6 & 0.0 & 0.0\end{array}$

Class Insecta

Chironomidae unid. spp

$\begin{array}{llllllllllllllllll}0.0 & 0.0 & 0.0 & 0.0 & 0.0 & 0.0 & 0.0 & 0.0 & 0.0 & 0.0 & 0.0 & 0.0 & 0.0 & 0.0 & 0.0 & 0.0 & 0.0 & 0.0\end{array}$

Class Malacostraca

Americhelidium unid. spp.

$\begin{array}{llllllllllllllllll}0.3 & 0.6 & 0.0 & 0.0 & 0.0 & 0.0 & 0.0 & 0.0 & 0.0 & 0.0 & 0.0 & 0.0 & 0.0 & 0.0 & 0.0 & 0.0 & 0.0 & 0.0\end{array}$

Ampelisca abdita

$\begin{array}{llllllllllllllllll}0.0 & 0.0 & 1.7 & 1.5 & 1.7 & 0.6 & 7.3 & 2.3 & 1.0 & 1.7 & 5.7 & 2.5 & 3.0 & 1.7 & 9.0 & 3.6 & 18.3 & 4.9\end{array}$

Ampithoe unid. spp.

$\begin{array}{llllllllllllllllll}0.0 & 0.0 & 0.0 & 0.0 & 0.0 & 0.0 & 0.0 & 0.0 & 0.0 & 0.0 & 0.0 & 0.0 & 0.0 & 0.0 & 0.0 & 0.0 & 0.0 & 0.0\end{array}$

Callianassidae unid. spp.

$\begin{array}{llllllllllllllllll}0.0 & 0.0 & 0.0 & 0.0 & 0.0 & 0.0 & 0.0 & 0.0 & 0.0 & 0.0 & 0.0 & 0.0 & 0.0 & 0.0 & 0.0 & 0.0 & 0.0 & 0.0\end{array}$

Caprella californica

$\begin{array}{llllllllllllllllll}0.0 & 0.0 & 0.0 & 0.0 & 0.0 & 0.0 & 0.0 & 0.0 & 0.0 & 0.0 & 0.0 & 0.0 & 0.0 & 0.0 & 0.0 & 0.0 & 0.0 & 0.0\end{array}$

Corophium alienense

$\begin{array}{llllllllllllllllll}0.0 & 0.0 & 0.3 & 0.6 & 0.0 & 0.0 & 0.0 & 0.0 & 0.0 & 0.0 & 0.0 & 0.0 & 0.0 & 0.0 & 0.0 & 0.0 & 0.0 & 0.0\end{array}$

Corophium heteroceratum

$\begin{array}{llllllllllllllllll}0.0 & 0.0 & 0.0 & 0.0 & 0.0 & 0.0 & 0.0 & 0.0 & 0.0 & 0.0 & 0.0 & 0.0 & 0.0 & 0.0 & 0.0 & 0.0 & 0.0 & 0.0\end{array}$

Corophium spinicorne

$\begin{array}{llllllllllllllllll}0.0 & 0.0 & 0.0 & 0.0 & 0.0 & 0.0 & 0.0 & 0.0 & 0.0 & 0.0 & 0.0 & 0.0 & 0.0 & 0.0 & 0.0 & 0.0 & 0.0 & 0.0\end{array}$

Corophium unid. spp.

$\begin{array}{llllllllllllllllll}0.3 & 0.6 & 0.0 & 0.0 & 0.0 & 0.0 & 0.0 & 0.0 & 0.0 & 0.0 & 0.0 & 0.0 & 0.0 & 0.0 & 0.0 & 0.0 & 0.0 & 0.0\end{array}$

Corophiidae unid. spp.

$\begin{array}{llllllllllllllllll}0.0 & 0.0 & 0.0 & 0.0 & 0.0 & 0.0 & 0.0 & 0.0 & 0.0 & 0.0 & 0.0 & 0.0 & 0.0 & 0.0 & 0.0 & 0.0 & 0.0 & 0.0\end{array}$

Crangon nigricauda

$\begin{array}{llllllllllllllllll}0.0 & 0.0 & 0.0 & 0.0 & 0.0 & 0.0 & 0.0 & 0.0 & 0.0 & 0.0 & 0.0 & 0.0 & 0.0 & 0.0 & 0.0 & 0.0 & 0.0 & 0.0\end{array}$

Cumella vulgaris

$\begin{array}{llllllllllllllllll}0.0 & 0.0 & 0.0 & 0.0 & 0.0 & 0.0 & 0.0 & 0.0 & 0.0 & 0.0 & 0.0 & 0.0 & 0.0 & 0.0 & 0.0 & 0.0 & 0.0 & 0.0\end{array}$




\begin{tabular}{|c|c|c|c|c|c|c|c|c|c|c|c|c|c|c|c|c|c|c|}
\hline \multirow{2}{*}{ TAXON } & \multicolumn{2}{|c|}{$1 / 17 / 2012$} & \multicolumn{2}{|c|}{ 2/15/2012 } & \multicolumn{2}{|c|}{$3 / 14 / 2012$} & \multicolumn{2}{|c|}{$4 / 25 / 2012$} & \multicolumn{2}{|c|}{$5 / 9 / 2012$} & \multicolumn{2}{|c|}{$6 / 8 / 2012$} & \multicolumn{2}{|c|}{$7 / 20 / 2012$} & \multicolumn{2}{|c|}{$8 / 17 / 2012$} & \multicolumn{2}{|c|}{ 9/17/2012 } \\
\hline & Mean & std dev & Mean & std dev & Mean & std dev & Mean & std dev & Mean & std dev & Mean & std dev & Mean & std dev & Mean & std dev & Mean & std dev \\
\hline Eogammarus confervicolus & 0.0 & 0.0 & 0.0 & 0.0 & 0.0 & 0.0 & 0.0 & 0.0 & 0.0 & 0.0 & 0.0 & 0.0 & 0.0 & 0.0 & 0.0 & 0.0 & 0.0 & 0.0 \\
\hline Gnorisphaeroma oregonensis & 0.0 & 0.0 & 0.0 & 0.0 & 0.0 & 0.0 & 0.0 & 0.0 & 0.0 & 0.0 & 0.0 & 0.0 & 0.0 & 0.0 & 0.0 & 0.0 & 0.0 & 0.0 \\
\hline Grandidierella japonica & 3.3 & 0.6 & 2.0 & 2.6 & 0.0 & 0.0 & 0.0 & 0.0 & 0.7 & 0.6 & 1.3 & 1.5 & 0.3 & 0.6 & 7.3 & 4.5 & 4.3 & 4.2 \\
\hline Hemigrapsus oregonensis & 0.0 & 0.0 & 0.0 & 0.0 & 0.0 & 0.0 & 0.0 & 0.0 & 0.0 & 0.0 & 0.0 & 0.0 & 0.0 & 0.0 & 0.0 & 0.0 & 0.0 & 0.0 \\
\hline Melita nitida & 0.0 & 0.0 & 0.0 & 0.0 & 0.0 & 0.0 & 0.0 & 0.0 & 0.0 & 0.0 & 0.0 & 0.0 & 0.0 & 0.0 & 0.0 & 0.0 & 0.0 & 0.0 \\
\hline Melita unid. spp. & 0.0 & 0.0 & 0.0 & 0.0 & 0.0 & 0.0 & 0.0 & 0.0 & 0.0 & 0.0 & 0.0 & 0.0 & 0.0 & 0.0 & 0.0 & 0.0 & 0.0 & 0.0 \\
\hline Monocorophium acherusicum & 0.0 & 0.0 & 1.0 & 1.0 & 0.0 & 0.0 & 0.0 & 0.0 & 0.0 & 0.0 & 0.0 & 0.0 & 0.0 & 0.0 & 0.0 & 0.0 & 0.0 & 0.0 \\
\hline Monocorophium insidiosum & 0.7 & 1.2 & 0.0 & 0.0 & 0.0 & 0.0 & 0.0 & 0.0 & 0.3 & 0.6 & 0.0 & 0.0 & 0.0 & 0.0 & 0.0 & 0.0 & 0.0 & 0.0 \\
\hline Monocorophium unid. spp. & 3.7 & 1.2 & 0.0 & 0.0 & 0.3 & 0.6 & 0.0 & 0.0 & 0.3 & 0.6 & 0.0 & 0.0 & 0.0 & 0.0 & 1.0 & 1.7 & 0.0 & 0.0 \\
\hline Mysidacea unid. spp. & 0.0 & 0.0 & 0.0 & 0.0 & 0.0 & 0.0 & 0.0 & 0.0 & 0.0 & 0.0 & 0.0 & 0.0 & 0.0 & 0.0 & 0.0 & 0.0 & 0.0 & 0.0 \\
\hline Nippoleucon hinumensis & 71.0 & 5.3 & 106.3 & 54.0 & 20.7 & 12.0 & 27.3 & 2.1 & 37.3 & 6.0 & 71.7 & 15.2 & 100.3 & 23.6 & 55.0 & 12.1 & 60.0 & 22.9 \\
\hline Sinelobus unid. spp. & 0.0 & 0.0 & 0.0 & 0.0 & 0.0 & 0.0 & 0.0 & 0.0 & 0.0 & 0.0 & 0.0 & 0.0 & 0.0 & 0.0 & 0.0 & 0.0 & 0.0 & 0.0 \\
\hline Sphaeromatidae unid. spp. & 0.0 & 0.0 & 0.0 & 0.0 & 0.0 & 0.0 & 0.0 & 0.0 & 0.0 & 0.0 & 0.0 & 0.0 & 0.0 & 0.0 & 0.0 & 0.0 & 0.0 & 0.0 \\
\hline Synidotea laevidorsalis & 0.0 & 0.0 & 0.0 & 0.0 & 0.0 & 0.0 & 0.0 & 0.0 & 0.3 & 0.6 & 2.0 & 3.5 & 0.0 & 0.0 & 0.0 & 0.0 & 0.0 & 0.0 \\
\hline Synidotea unid. spp. & 0.0 & 0.0 & 0.0 & 0.0 & 0.0 & 0.0 & 0.0 & 0.0 & 0.0 & 0.0 & 0.0 & 0.0 & 0.0 & 0.0 & 0.0 & 0.0 & 0.0 & 0.0 \\
\hline
\end{tabular}

\section{Class Ostacoda}

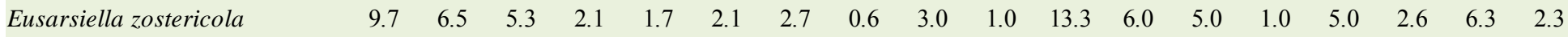

$\begin{array}{lllllllllllllllllll}\text { Cyprideis unid. spp. } & 0.0 & 0.0 & 0.0 & 0.0 & 0.0 & 0.0 & 0.0 & 0.0 & 0.0 & 0.0 & 0.0 & 0.0 & 0.0 & 0.0 & 0.0 & 0.0 & 0.0 & 0.0\end{array}$

Class Thecostraca

$\begin{array}{lllllllllllllllllll}\text { Amphibalanus improvisus } & 0.7 & 1.2 & 0.3 & 0.6 & 0.0 & 0.0 & 0.7 & 1.2 & 0.0 & 0.0 & 0.7 & 0.6 & 1.0 & 1.0 & 1.0 & 1.7 & 0.7 & 1.2\end{array}$

$\begin{array}{llllllllllllllllllll}\text { Balanomorpha unid. spp. } & 0.0 & 0.0 & 0.0 & 0.0 & 0.0 & 0.0 & 0.0 & 0.0 & 0.3 & 0.6 & 0.3 & 0.6 & 0.0 & 0.0 & 0.3 & 0.6 & 0.0 & 0.0\end{array}$

$\begin{array}{lllllllllllllllllllll}\text { Cirripedia unid. spp. } & 0.0 & 0.0 & 0.0 & 0.0 & 0.0 & 0.0 & 0.0 & 0.0 & 0.0 & 0.0 & 0.0 & 0.0 & 0.0 & 0.0 & 0.0 & 0.0 & 0.0 & 0.0\end{array}$

\section{PHYLUM CNIDARIA}

\section{Class Anthozoa}

$\begin{array}{llllllllllllllllllll}\text { Actiniaria - attached } & 0.3 & 0.6 & 0.3 & 0.6 & 0.0 & 0.0 & 0.0 & 0.0 & 0.0 & 0.0 & 0.0 & 0.0 & 0.0 & 0.0 & 0.0 & 0.0 & 0.3 & 0.6\end{array}$

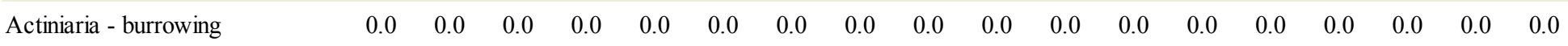

$\begin{array}{lllllllllllllllllllll}\text { Actiniaria unid. spp. } & 0.0 & 0.0 & 0.0 & 0.0 & 0.0 & 0.0 & 0.0 & 0.0 & 0.0 & 0.0 & 0.0 & 0.0 & 0.0 & 0.0 & 0.0 & 0.0 & 0.0 & 0.0\end{array}$ 


\begin{tabular}{|c|c|c|c|c|c|c|c|c|c|c|c|c|c|c|c|c|c|c|}
\hline \multirow{2}{*}{ TAXON } & \multicolumn{2}{|c|}{$1 / 17 / 2012$} & \multicolumn{2}{|c|}{$2 / 15 / 2012$} & \multicolumn{2}{|c|}{$3 / 14 / 2012$} & \multicolumn{2}{|c|}{$4 / 25 / 2012$} & \multicolumn{2}{|c|}{$5 / 9 / 2012$} & \multicolumn{2}{|c|}{ 6/8/2012 } & \multicolumn{2}{|c|}{$7 / 20 / 2012$} & \multicolumn{2}{|c|}{$8 / 17 / 2012$} & \multicolumn{2}{|c|}{ 9/17/2012 } \\
\hline & Mean & std dev & Mean & std dev & Mean & std dev & Mean & std dev & Mean & std dev & Mean & std dev & Mean & std dev & Mean & std dev & Mean & std dev \\
\hline \multicolumn{19}{|l|}{ PHYLUM MOLLUSCA } \\
\hline \multicolumn{19}{|l|}{ Class Bivalvia } \\
\hline Bivalvia unid. spp. & 0.0 & 0.0 & 0.0 & 0.0 & 0.0 & 0.0 & 0.0 & 0.0 & 0.0 & 0.0 & 0.0 & 0.0 & 0.0 & 0.0 & 0.0 & 0.0 & 0.0 & 0.0 \\
\hline Gemma geтma & 125.3 & 20.8 & 156.7 & 30.8 & 143.7 & 35.1 & 427.0 & 90.1 & 358.3 & 163.4 & 502.7 & 72.5 & 374.3 & 144.1 & 398.7 & 110.7 & 346.0 & 175.3 \\
\hline Macoma petalum & 3.3 & 1.5 & 4.3 & 0.6 & 2.3 & 1.5 & 7.7 & 2.1 & 11.0 & 2.0 & 6.0 & 1.7 & 4.3 & 2.3 & 2.3 & 1.5 & 5.3 & 2.5 \\
\hline Macoma unid. spp. & 0.0 & 0.0 & 0.0 & 0.0 & 1.0 & 1.0 & 0.0 & 0.0 & 0.0 & 0.0 & 0.0 & 0.0 & 0.0 & 0.0 & 0.3 & 0.6 & 0.0 & 0.0 \\
\hline Musculista senhousia & 0.0 & 0.0 & 0.0 & 0.0 & 0.0 & 0.0 & 0.0 & 0.0 & 0.0 & 0.0 & 0.0 & 0.0 & 0.0 & 0.0 & 0.0 & 0.0 & 0.0 & 0.0 \\
\hline Mya arenaria & 0.3 & 0.6 & 0.0 & 0.0 & 0.0 & 0.0 & 0.7 & 0.6 & 2.7 & 0.6 & 7.3 & 1.5 & 2.0 & 1.7 & 1.0 & 0.0 & 1.7 & 1.5 \\
\hline Potamocorbula amurensis & 3.7 & 1.5 & 3.0 & 1.0 & 0.0 & 0.0 & 2.0 & 0.0 & 5.0 & 1.0 & 3.0 & 2.0 & 8.0 & 2.6 & 7.3 & 1.5 & 3.0 & 1.7 \\
\hline Rochefortia grippi & 0.0 & 0.0 & 0.0 & 0.0 & 0.0 & 0.0 & 0.0 & 0.0 & 0.0 & 0.0 & 0.0 & 0.0 & 0.0 & 0.0 & 0.0 & 0.0 & 0.0 & 0.0 \\
\hline Rochefortia unid. spp. & 0.0 & 0.0 & 0.0 & 0.0 & 0.0 & 0.0 & 0.0 & 0.0 & 0.0 & 0.0 & 0.0 & 0.0 & 0.0 & 0.0 & 0.0 & 0.0 & 0.0 & 0.0 \\
\hline Tellinidae unid. spp. & 0.0 & 0.0 & 0.0 & 0.0 & 0.0 & 0.0 & 0.0 & 0.0 & 0.0 & 0.0 & 0.0 & 0.0 & 0.0 & 0.0 & 0.0 & 0.0 & 0.0 & 0.0 \\
\hline
\end{tabular}

\section{Class Gastropoda}

\begin{tabular}{|c|c|c|c|c|c|c|c|c|c|c|c|c|c|c|c|c|c|c|}
\hline Gastropoda unid. sp. B & 0.0 & 0.0 & 0.0 & 0.0 & 0.0 & 0.0 & 0.0 & 0.0 & 0.0 & 0.0 & 0.0 & 0.0 & 0.0 & 0.0 & 0.0 & 0.0 & 0.0 & 0.0 \\
\hline Ilyanassa obsoleta & 0.0 & 0.0 & 0.0 & 0.0 & 0.3 & 0.6 & 1.0 & 1.7 & 0.0 & 0.0 & 0.7 & 1.2 & 0.0 & 0.0 & 0.0 & 0.0 & 0.0 & 0.0 \\
\hline Odetta bisuturalis & 1.3 & 0.6 & 0.7 & 1.2 & 2.0 & 1.0 & 0.7 & 0.6 & 1.0 & 1.0 & 1.3 & 2.3 & 0.7 & 0.6 & 1.0 & 1.0 & 0.3 & 0.6 \\
\hline Philine unid. spp. & 0.0 & 0.0 & 0.0 & 0.0 & 0.0 & 0.0 & 0.0 & 0.0 & 0.0 & 0.0 & 0.0 & 0.0 & 0.0 & 0.0 & 0.0 & 0.0 & 0.0 & 0.0 \\
\hline Pyramidellidae unid. sp. A & 0.0 & 0.0 & 0.0 & 0.0 & 0.7 & 1.2 & 1.3 & 2.3 & 0.0 & 0.0 & 0.0 & 0.0 & 0.3 & 0.6 & 0.0 & 0.0 & 0.0 & 0.0 \\
\hline Urosalpinx cinerea & 0.0 & 0.0 & 0.0 & 0.0 & 0.0 & 0.0 & 0.0 & 0.0 & 0.0 & 0.0 & 0.0 & 0.0 & 0.0 & 0.0 & 0.0 & 0.0 & 0.0 & 0.0 \\
\hline
\end{tabular}

\section{PHYLUM NEMATODA}

$\begin{array}{lllllllllllllllllllll}\text { Nematoda unid. spp. } & 0.3 & 0.6 & 0.3 & 0.6 & 0.3 & 0.6 & 0.7 & 0.6 & 7.0 & 11.3 & 0.0 & 0.0 & 0.0 & 0.0 & 0.0 & 0.0 & 0.7 & 1.2\end{array}$

\section{PHYLUM PLATYHELMINTHES}

Class Turbellaria

\begin{tabular}{|c|c|c|c|c|c|c|c|c|c|c|c|c|c|c|c|c|c|}
\hline Turbellaria unid. sp. A & 0.0 & 0.0 & 0.0 & 0.0 & 0.0 & 0.0 & 0.0 & 0.0 & 0.0 & 0.0 & 0.0 & 0.0 & 0.0 & 0.0 & 0.0 & 0.0 & 0.0 \\
\hline Turbellaria unid. spp. & 0.0 & 0.0 & 0.0 & 0.0 & 0.0 & 0.0 & 0.0 & 0.0 & 0.0 & 0.0 & 0.0 & 0.0 & 0.0 & 0.0 & 0.0 & 0.0 & 0.0 \\
\hline
\end{tabular}


Appendix 11. Benthic species name changes as of 2012.

\begin{tabular}{|c|c|}
\hline Current Species Name: & Formerly Documented As: \\
\hline \multicolumn{2}{|l|}{$\begin{array}{l}\text { PHYLUM ANNELIDA } \\
\end{array}$} \\
\hline \multicolumn{2}{|l|}{ Class Oligochaeta } \\
\hline Naididae unid. spp. & Naididae \\
\hline Oligochaeta unid. spp. & Oligochaeta, Unid. Oligochaeta family \\
\hline Tubificidae unid. spp. & Tubificidae \\
\hline \multicolumn{2}{|l|}{ Class Polychaeta } \\
\hline Capitella capitata complex & Capitella "capitata" \\
\hline Cirratulidae unid. spp. & Tharyx spp. ?, Cirratulidae \\
\hline Eteone unid. spp. & Eteone spp., Eteone ?californica \\
\hline Euchone unid. spp. & Euchone spp. \\
\hline Glycera unid. spp. & Glycera spp. \\
\hline Glycinde picta & Glycinde polygnatha \\
\hline Glycinde unid. sp. SF1 & Glycinde sp. SF1 \\
\hline Glycinde unid. spp. & Glycinde spp. \\
\hline Maldanidae unid. spp. & Unid. Malanidae \\
\hline Polychaeta unid. spp. & Unid. Polychaeta, Polychaeta \\
\hline Polydora cornuta & Polydora lighti, Polydora ligni \\
\hline Polydora unid. spp. & Polydora spp. \\
\hline Sphaerosyllis unid. sp. A & Sphaerosyllis spp. \\
\hline Spionidae unid. spp. & Unid. Spionidae, Spionidae Unidentified \\
\hline \multicolumn{2}{|l|}{ PHYLUM ARTHROPODA } \\
\hline \multicolumn{2}{|l|}{ Class Copepoda } \\
\hline Calanoida unid. spp. & Calinoida \\
\hline Harpacticoida unid. spp. & Harpacticoida \\
\hline \multicolumn{2}{|l|}{ Class Insecta } \\
\hline Chironomidae unid. spp. & Chironomidae \\
\hline \multicolumn{2}{|l|}{ Class Malacos traca } \\
\hline Americhelidium unid. spp. & Americhelidium spp., Synchelidium spp. \\
\hline Ampithoe unid. spp. & Ampithoe spp. \\
\hline Callianassidae unid. spp. & Callianassidae, Callianassidae unidentified \\
\hline Corophium unid. spp. & Corophiidae - unidentified \\
\hline Corophiidae unid. spp. & Corophium spp. \\
\hline Eogammarus confervicolus & Anisogammarus confervicolus \\
\hline Gnorisphaeroma oregonensis & $\begin{array}{l}\text { Gnorisphaeroma oregonensis, } \\
\text { Gnorimosphaeroma oregonensis }\end{array}$ \\
\hline Melita unid. spp. & Melita spp. \\
\hline Monocorophium acherusicum & Corophium acherusicum \\
\hline Monocorophium insidiosum & Corophium insidiosum \\
\hline
\end{tabular}




\begin{tabular}{ll}
\hline Current Species Name: & Formerly Documented As: \\
\hline Monocorophium unid. spp. & $\begin{array}{l}\text { Corophium ?insidiosum, Corophium spp. } \\
\text { (female \& juvenile), Corophium spp. } \\
\text { (male), Monocorophium spp. }\end{array}$ \\
Mysidacea unid. spp. & Mysidacea \\
Nippoleucon hinumensis & Hemileucon hinumensis \\
Sinelobus unid. spp. & Sinelobus stanfordi, Sinolobus spp., \\
& Sinolobus stanfordi, Tanais spp. \\
Sphaeromatidae unid. spp. & Sphaeromatidae (juv.), Sphaeromatidae \\
Synidotea unid. spp. & unid., Dynamella spp. \\
Clas s Os tacoda & Synidotea spp. \\
Eusarsiella zostericola & Sarsiella zostericola \\
Cyprideis unid. spp. & Cyprideis spp. \\
Class Thecostraca & Balanus improvisus \\
Amphibalanus improvisus & Balanus ?aquila, Balanus spp., Unid. \\
Balanomorpha unid. spp. & Balanomorpha, Balanomorpha - \\
Cirripedia unid. spp. & unidentified \\
\hline
\end{tabular}

PHYLUM CNIDARIA

Class Anthozoa

Actiniaria unid. spp.

Anthozoa, Unid. Actiniaria

\section{PHYLUM MOLLUSCA}

\section{Class Bivalvia}

Bivalvia unid. spp.

Macoma petalum

Macoma unid. spp.

Potamocorbula amurensis

Rochefortia unid. spp.

Tellinidae unid. spp.

\section{Class Gas tropoda}

Gastropoda unid. sp. B

Ilyanassa obsoleta

Odetta bisuturalis

Philine unid. spp.

Pyramidellidae unid. sp. A
Unid. Bivalvia

Macoma balthica

Macoma spp.

Corbula amurensis

Rochefortia spp.

Tellinidae

Unidentified Gastropoda B

Nassarius obsoletus

Boonea bisuturalis, Odostomia fetella

Philine spp.

Odostomia spp., Pyramidellidae, Unidentified Gastropod A

Nematoda
PHYLUM NEMATODA

Nematoda unid. spp.

\section{PHYLUM PLATYHELMINTHES}

\section{Class Turbellaria}

Turbellaria unid. sp. A

Turbellaria unid. spp.

Turbellaria unid. sp. A

Turbellaria unid. spp.
Planariidae A

Turbellaria

Planariidae A

Turbellaria 